UNIVESIDADE DE SÃO PAULO

FACULDADE DE ECONOMIA, ADMINISTRAÇÃO E CONTABILIDADE PROGRAMA DE PÓS-GRADUAÇÃO EM ADMINISTRAÇÃO

A Contribuição do e-Learning no Desenvolvimento de Competências do Administrador: Considerando o Estilo de Aprendizagem do Aluno de Graduação

\author{
LILIANA VASCONCELLOS JACOBSOHN
}

Orientadora: PROF ${ }^{\mathrm{a}}$. DR ${ }^{\mathrm{a}}$. MARIA TEREZA LEME FLEURY

São Paulo

2003 
Reitor da Universidade de São Paulo

Prof. Dr. Adolpho José Melfi

Diretora da Faculdade de Economia, Administração e Contabilidade Prof ${ }^{\mathrm{a}}$. Dr ${ }^{\mathrm{a}}$. Maria Tereza Leme Fleury

Chefe do Departamento de Administração

Prof. Dr. Eduardo Pinheiro Gondim de Vasconcellos 


\title{
A Contribuição do e-Learning no Desenvolvimento de Competências do Administrador: Considerando o Estilo de Aprendizagem do Aluno de Graduação
}

\author{
LILIANA VASCONCELLOS JACOBSOHN
}

Orientadora: PROF ${ }^{\mathrm{a}}$. DR ${ }^{\mathrm{a}}$. MARIA TEREZA LEME FLEURY

Dissertação apresentada à Faculdade de Economia, Administração e Contabilidade da Universidade de São Paulo, como parte dos requisitos para obtenção do título de Mestre em Administração de Empresas.

São Paulo 


\section{FICHA CATALOGRÁFICA}

Jacobsohn, Liliana Vasconcellos

A contribuição do e-learning no desenvolvimento de competências do administrador: considerando o estilo de aprendizagem do aluno de graduação / Liliana Vasconcellos Jacobsohn. -- São Paulo : FEA/USP, 2003.

$215 \mathrm{p}$.

Dissertação - Mestrado

Bibliografia

1. Ensino superior - Administração 2. Educação a distância 3. Aprendizagem I. Faculdade de Economia, Administração e Contabilidade da USP.

CDD -378 
Aos meus pais, Regina e Eduardo, que inspiraram minha trajetória acadêmica e sempre me apoiaram na busca pela realização dos meus sonhos. 


\section{AGRADECIMENTOS}

Após dois anos e meio de trabalho, é com grande satisfação que agradeço àqueles que, de diferentes maneiras, tornaram esta experiência extremamente rica, tendo contribuído de forma significativa para meu crescimento profissional e pessoal.

Ao meu pai, Eduardo Vasconcellos, meu mentor desde que ingressei na área de Administração, agradeço pelos ensinamentos, pelas oportunidades de trabalho conjunto, pelas discussões muito estimulantes, pelas palavras de incentivo nos momentos de desânimo, por estar sempre presente, me dando apoio em todos os momentos da minha trajetória profissional.

À minha orientadora, professora Maria Tereza Leme Fleury agradeço por ter acreditado no meu projeto, pela excelente orientação, que me deu espaço para que eu encontrasse meu caminho e, ao mesmo tempo, me ajudou a manter o foco do trabalho, e pelo apoio às minhas escolhas durante a pesquisa. Agradeço, também, pelas valiosas discussões, pelo suporte na realização das atividades de e-learning no caso estudado e por me convidar para participar de outros projetos sobre o tema, o que possibilitou ampliar meu conhecimento e experiência.

À professora Tânia Casado pela ajuda preciosa, sem a qual não seria possível analisar o estilo de aprendizagem dos alunos com tanta profundidade. Muito obrigada por ter aplicado o questionário e por ter me ajudado na interpretação dos resultados.

À professora Ana Cristina Limongi França pelo espaço disponibilizado na disciplina Administração de RH I e pelo apoio na implantação das atividades de e-learning e na realização da pesquisa.

Aos professores André Luiz Fischer e James T. C. Wright pelas valiosas contribuições por ocasião do exame de qualificação. Ao professor Gilberto Martins, pela oportunidade de apresentar e discutir meu projeto de pesquisa no evento Discussões Metodológicas e pelas conversas que muito ajudaram na análise dos resultados, principalmente nas questões estatísticas. Ao professor Isak Kruglianskas pelas discussões e sugestões, durante a disciplina de Seminário de Elaboração de Estudos e Pesquisas em Administração.

Agradeço aos alunos que participaram da disciplina Administração de RH I, em 2002, pela colaboração e contribuição na realização desta pesquisa. 
À Valéria Lourenção e sua equipe, da Secretaria de Pós-graduação da FEA/USP, e à Eloisa Martins Aléssio, Daniela Alves Martins e Fabiana de Cassia Caseira Chiuratto, da Secretaria do Programa de Pós-graduação do Departamento de Administração, pelo atendimento, simpatia e apoio durante todo o curso de mestrado. À Olga Marques e Maria Fernanda André Borba, do Departamento de Administração, e à Daniela Fonseca da Secretaria de Graduação do Departamento de Administração, pela ajuda no fornecimento de dados sobre o curso de graduação. À Lucimara Aparecida do Nascimento, Maria Eneida Chiuzini e Regina Maria Mattos Macedo de Almeida pela ajuda em vários momentos do curso.

Aos professores do Programa de Pós-graduação do Departamento de Administração da FEA/USP e à professora Stela Piconez, da Faculdade de Educação/USP, com os quais tive a oportunidade de aprender muito durante o cumprimento dos créditos.

À minha amiga Andréa Kanikadan, pelo apoio durante a realização das atividades de e-learning na disciplina estudada e pela ajuda na tabulação dos dados. Aos amigos do Programa de Pós-graduação e à amiga Claudia Escarabajal, com os quais pude trocar experiências e dividir minhas preocupações nos momentos difíceis.

À CAPES - Coordenação de Aperfeiçoamento de Pessoal de Nível Superior, pela bolsa de estudo e pelo recurso disponibilizado através do Programa PAPED - Programa de Apoio à Pesquisa em Educação a Distância, apoio fundamental na realização do mestrado e na elaboração desta pesquisa. À Dayse Gomes, da CAPES/PAPED, pela prontidão e simpatia no atendimento às minhas dúvidas.

À FIA - Fundação Instituto de Administração, que viabilizou minha participação no ENANPAD 2002, para apresentação de trabalho sobre $e$-learning.

À minha mãe, Regina Araújo de Almeida, pelas discussões estimulantes sobre educação, que ampliaram meu conhecimento sobre o tema, e por toda a ajuda e apoio, essenciais para a realização deste trabalho.

Aos meus irmãos, Adriano e André Vasconcellos, pelo apoio, paciência e amizade.

Ao meu marido, Jorge Jacobsohn Wolvovich, pelo incentivo, compreensão e companheirismo.

A todos que contribuíram para este trabalho, inclusive aqueles não citados, muito obrigada! 


\section{A CONTRIBUIÇÃO DO e-LEARNING NO DESENVOLVIMENTO DE COMPETÊNCIAS DO ADMINISTRADOR: CONSIDERANDO O ESTILO DE APRENDIZAGEM DO ALUNO DE GRADUAÇÃO}

\section{RESUMO}

O contexto atual em constante mudança determina a necessidade de formar um administrador preparado para assumir a responsabilidade por seu próprio aprendizado, possibilitando sua educação durante toda a vida, e também para trabalhar utilizando as tecnologias de informação cada vez mais presentes no ambiente corporativo. Dessa forma, o objetivo geral deste trabalho é analisar a contribuição do e-learning, como atividade complementar no curso de graduação, para o desenvolvimento de competências do administrador. Na primeira fase do estudo foi conduzida uma pesquisa bibliográfica sobre a formação do administrador, teorias e estilo de aprendizagem e e-learning. Na segunda fase, foi realizada a pesquisa empírica, com os 119 alunos de uma disciplina do curso de graduação em Administração de Empresas da FEA/USP. Os resultados da pesquisa indicam a necessidade de inserção do e-learning na agenda de discussão das Instituições de Ensino Superior, tendo em vista seu potencial para estimular o desenvolvimento da autoaprendizagem e da atuação em ambientes virtuais, além das competências técnicas. Ao levar em consideração o estilo de aprendizagem dos alunos, os resultados tendem a confirmar que não são todas as pessoas que se adaptam ao e-learning, resultando em contribuições diferenciadas dependendo das preferências do aluno em relação ao processo de aprendizagem.

Palavras-chave: Ensino superior - Administração. Educação a distância. Aprendizagem. 


\title{
THE $e$-LEARNING CONTRIBUTION TO THE DEVELOPMENT OF MANAGER'S COMPETENCES: CONSIDERING THE UNDERGRADUATE STUDENT'S LEARNING STYLE
}

\begin{abstract}
Given the ever-changing business environment, life-long learning and working with information technology are now essential for all managers. This study examines how elearning can contribute to undergraduate management education, regarding the development of student's competences. The research first reviewed e-learning and management education literature, including learning theories and styles. In the second phase, empirical research was conducted using 119 students from the Introduction to Human Resources Management course, part of the management undergraduate program at FEA/USP. The results tend to confirm that not all people can adapt to e-learning. Depending on a student's preferences with respect to his or her own learning process, e-learning benefits can vary. The research results support adding e-learning to the Higher Education Institutions' discussion agenda. Factors to consider include e-learning's potential for stimulating the development of self-learning and conduct in a virtual environment, besides technical competences, and how learning styles affect the ability to utilize this teaching method.
\end{abstract}

Keywords: Management Undergraduate Teaching. Distance Education. Learning. 


\section{SUMÁRIO}

AGRADECIMENTOS__ vi

RESUMO _ viii

ABSTRACT _ ix

APRESENTAÇÃO__

1. INTRODUÇÃO

1.1 O Contexto Atual___ 3

1.2 Os Objetivos da Pesquisa __ 5

1.3 A Justificativa da Pesquisa___ 8

2. REVISÃO BIBLIOGRÁFICA

2.1 A Formação do Administrador _ 12

2.1.1 O Histórico do Ensino Superior da Administração ___ 13

2.1.2 O Currículo de Administração ___ 15

2.1.3 As Competências do Administrador____ 17

2.2 A Aprendizagem _ 23

2.2.1 As Teorias de Aprendizagem e as Técnicas de Ensino ___ 24

2.2.2 O Estilo de Aprendizagem ___ 31

2.2.3 A Aprendizagem e as Competências _ـ 40

2.2.4 A Avaliação da Aprendizagem___ 42

2.3 O e-Learning _ 45

2.3.1 O Histórico _ 47

2.3.2 Os Benefícios e os Problemas __ 51

2.3.3 A Gestão Integrada da Educação a Distância____ 60

2.3.4 As Atividades de e-Learning ___ 63

2.3.5 O e-Learning Aplicado ao Ensino da Administração___ 72

3. METODOLOGIA DA PESQUISA

3.1 O Estudo de Caso _ 78

3.1.1 A Estratégia do Estudo de Caso e a Pesquisa-ação ___ 78

3.1.2 A Descrição do Caso Escolhido _ _ 80

3.1.3 Escopo da Pesquisa____ 84

3.2 As Variáveis da Pesquisa 
3.3 Necessidade e Fontes de Dados

3.4 Técnicas e Instrumentos de Coleta dos Dados __ 89

3.4.1 Os Questionários Auto-preenchidos___ 91

3.4.2 A Entrevista Individual___ 94

3.5 A População e a Amostra __ 95

3.5.1 População e Unidade de listagem ___ 96

3.5.2 Método de amostragem __ 96

3.5.3 Composição dos Elementos da Pesquisa ___ 97

3.6 O Modelo da Pesquisa___ 99

4. ANÁLISE DOS RESULTADOS

4.1 A contribuição das atividades de e-learning para o desenvolvimento de competências técnicas, foco da disciplina 102

4.1.1 O Conteúdo___ 104

4.1.2 Os Testes Auto-corrigidos __ 107

4.1.3 O WebQuest ___ 111

4.1.4 O Fórum _ 116

4.1.5 O Chat__ 127

4.1.6 Satisfação geral em relação ao e-learning ___ 140

4.2 A contribuição das atividades de e-learning no desenvolvimento de competências de aprendizagem e competências sociais

4.2.1 As Competências de Aprendizagem___ 153

4.2.2 As Competências Sociais __ 159

4.3 A influência do estilo de aprendizagem do aluno na utilização do e-learning para o desenvolvimento de competências do administrador___ 163

4.3.1 O Perfil Geral _ـ 163

4.3.2 A relação com o objeto: Introversão / Extroversão ___ 165

4.3.3 As Outras Funções Psicológicas___ 170

5. CONSIDERAÇÕES FINAIS _ 176

6. REFERÊNCIAS BIBLIOGRÁFICAS

APÊNDICE A: Aulas Virtuais __ 199

APÊNDICE B: Atividade WebQuest __ 205

APÊEDICE C: Questionário de Avaliação ___ 208

APÊNDICE D: Questionário de Perfil__ 213

APÊNDICE E: Roteiro da Entrevista Individual __ 215 


\section{LISTA DE FIGURAS}

Figura 1 - Esquema do Estudo .7

Figura 2 - Competências como fonte de valor para o indivíduo e para a organização... .18

Figura 3 - Um esquema tentativo para os principais enfoques teóricos à aprendizagem e ao ensino e alguns de seus mais conhecidos representantes...

Figura 4 - Participação e Controle do Professor e Aluno .....................................................................26

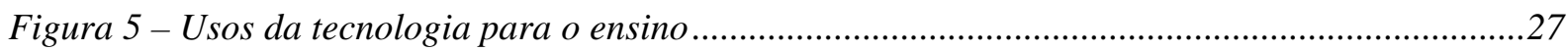

Figura 6 - Categorias para Agrupar as Teorias de Estilo de Aprendizagem .......................................35

Figura 7 - Ciclo de Aprendizagem das Competências Globais................................................................41

Figura 8 - Problemas de Grupos e Equipes Virtuais ..........................................................................55

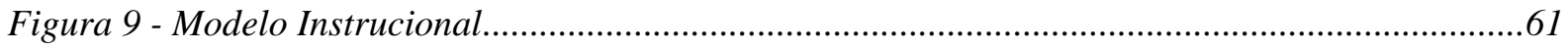

Figura 10 - Gestão Integrada da Educação a Distância .......................................................................62

Figura 11 - Mídias para disponibilizar ensino a distância ......................................................................64

Figura 12 - Página Inicial do Ambiente da Disciplina na Internet......................................................84

Figura 13 - Modelo da Pesquisa ................................................................................................100

Figura 14 - Resumo das Possíveis Relações Explicativas da Contribuição do Teste Auto-corrigido para o Aprendizado do Aluno ........................................................................................111

Figura 15 - Resumo das Possíveis Relações Explicativas da Contribuição do WebQuest para o Aprendizado do Aluno ...............................................................................................116

Figura 16 - Resumo das Possíveis Relações Explicativas da Contribuição do Fórum para o

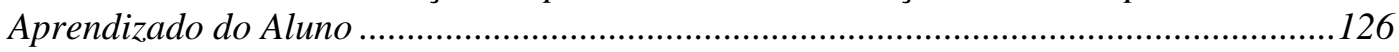

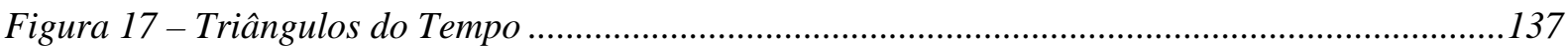

Figura 18 - Resumo das Possíveis Relações Explicativas da Contribuição do Chat para o Aprendizado do Aluno.

Figura 19 - Resumo das Possíveis Relações Explicativas da Contribuição do e-Learning para o Aprendizado do Aluno 


\section{LISTA DE QUADROS}

Quadro 1 - Número de Escolas de Economia e Administração, por Período, no Estado de São Paulo

Quadro 2 - Visão dos Administradores em Relação à Aprendizagem .................................................22

Quadro 3 - Teorias e Instrumentos de Estilo de Aprendizagem ............................................................33

Quadro 4 - Resumo das Teorias e Instrumentos de Estilos de Aprendizagem........................................34

Quadro 5 - Preferências de Aprendizado, por Tipo Psicológico .............................................................39

Quadro 6 - Processo de Desenvolvimento de Competências ................................................................42

Quadro 7 - A Sala de Aula Virtual: Situação da Educação a Distância no País ...................................49

Quadro 8 - Modelos de Educação a Distância - Uma Estrutura Conceitual........................................50

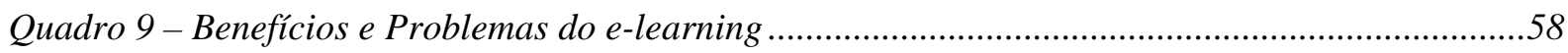

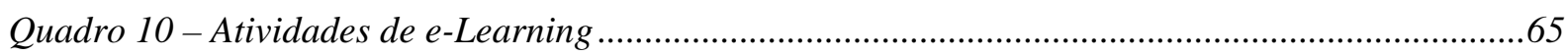

Quadro 11 - Vantagens e Desvantagens da Comunicação Mediada por Computador ........................67

Quadro 12 - Ferramentas do Curso Online ..................................................................................68

Quadro 13 - Táticas do estudo de caso para quatro testes de projeto...................................................79

Quadro 14 - Atividades de e-Learning Realizadas na Disciplina Administração de RH1 ...................82

Quadro 15 - Variáveis e Indicadores da Pesquisa por Dimensão ........................................................85

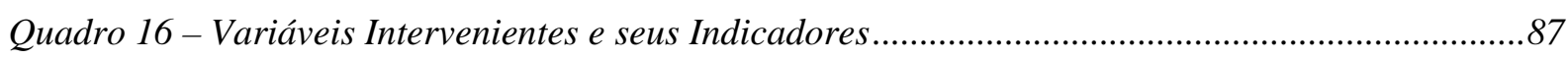

Quadro 17 - Necessidade e fontes de dados.....................................................................................89

Quadro 18 - Necessidade de Dados Primários e Técnica/Instrumentos de Coleta ..............................90

Quadro 19 - Vantagens e Desvantagens da Entrevista Individual em Profundidade ...........................94

Quadro 20 - Número de Questionários Válidos para cada Instrumento ..............................................97

Quadro 21 - Comentários dos Alunos sobre as Melhorias no Chat....................................................138

Quadro 22 - Resumo das Sugestões de Melhoria para cada Atividade de e-Learning ........................152

Quadro 23 - Preferências de Aprendizado dos Tipos Introversão / Extroversão ................................166

Quadro 24 - Preferências de Aprendizado dos Tipos Psicológicos (complemento do Quadro 23)....170 


\section{LISTA DE TABELAS}

Tabela 1 - Número de Alunos Aprovados no Processo Seletivo do Curso de Administração a Distância na FAAB, por Centro Regional...

Tabela 2 - Distribuição das Opiniões dos Alunos sobre as Variáveis da Dimensão Atividades de e-Learning

Tabela 3 - Distribuição das Opiniões dos Alunos sobre o Grau de Contribuição das atividades de e-Learning no Desenvolvimento de Competências Técnicas 104

Tabela 4 - Níveis de Utilização do Conteúdo do Curso Abril-FIA ( $1^{\circ}$ Módulo). 106

Tabela 5 - Média e Desvio Padrão das Notas* Atribuídas pelos Alunos sobre a Contribuição do Fórum para o Aprendizado, por Nível de Participação no Fórum**

Tabela 6 - Média e Desvio Padrão das Notas na Disciplina, por Nota Atribuída em Relação à Contribuição das Atividades de e-Learning para o Aprendizado.....

Tabela 7 - Média e Desvio Padrão da Nota Final dos Alunos Aprovados na Disciplina Administração de RH I (Diurno), por Período de Realização e por Nível de Participação Online*

Tabela 8 - Distribuição das Opiniões dos Alunos sobre o Grau de Contribuição do e-Learning no Desenvolvimento de Competências de Aprendizagem e Sociais

Tabela 9 - Média e Desvio Padrão das Notas* Atribuídas pelos Alunos para as Atividades de e-Learning, por Faixa de Nota* Atribuída para a Contribuição do e-Learning no Desenvolvimento da Auto-aprendizagem

Tabela 10 - Média e Desvio Padrão das Notas* Atribuídas pelos Alunos para as Atividades de e-Learning, por Faixa de Nota* Atribuída para a Contribuição do e-Learning no Desenvolvimento da Comunicação em Ambientes Virtuais e da Participação em Discussões.

Tabela 11 - Ocorrências Absolutas e Percentuais Totais de Tipo Psicológico, por Dimensão. 164

Tabela 12 - Freqüência dos Tipos Introversão e Extroversão em Relação ao Nível de Participação Online ......

Tabela 13 - Média e Desvio Padrão das Notas* Atribuídas pelos Alunos para o Desenvolvimento de Competências, por Tipo Introversão/Extroversão

Tabela 14 - Média e Desvio Padrão das Notas* Atribuídas pelos Alunos para o Desenvolvimento de Competências, por Tipo Psicológico (complemento da Tabela 13). 


\section{LISTA DE GRÁFICOS}

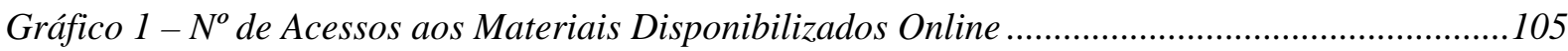

Gráfico 2 - Distribuição dos Alunos por Número de Testes Auto-corrigidos Completados................107

Gráfico 3 - Distribuição das Notas Atribuídas pelos Alunos sobre a Contribuição dos Testes Auto-corrigidos para o Aprendizado

Gráfico 4 - Distribuição das Notas Atribuídas pelos Alunos sobre a Contribuição dos Testes Auto-corrigidos para o Aprendizado, por \% de Presença nas Aulas em Classe ...........109

Gráfico 5 - Distribuição das Notas Atribuídas pelos Alunos sobre a Contribuição do WebQuest para o Aprendizado

Gráfico 6 - Distribuição das Notas Atribuídas pelos Alunos sobre a Contribuição do WebQuest para o Aprendizado, por Nível de Interesse em Gestão de Pessoas.

Gráfico 7 -Número de Mensagens Enviadas ao Fórum por Todos os Alunos da Disciplina e pelos Alunos que Responderam os Três Questionários da Pesquisa..

Gráfico 8 - Distribuição das Notas Atribuídas pelos Alunos sobre a Contribuição do WebQuest para o Aprendizado, por Número de Mensagens Enviadas ao Fórum ...........................114

Gráfico 9 - Distribuição das Mensagens Enviadas ao Fórum pelos Alunos, Considerando seu Conteúdo (Assunto e Intenção)

Gráfico 10 - Número de Mensagens Lidas no Fórum por Todos os Alunos da Disciplina e pelos Alunos que Responderam os Três Questionários da Pesquisa.

Gráfico 11 - Número de Mensagens Lidas no Fórum por Número de Mensagens Enviadas...

Gráfico 12 - Distribuição das Notas Atribuídas pelos Alunos sobre o Fórum ...

Gráfico 13 - Distribuição dos Alunos que Mencionaram a Falta de Tempo como uma Dificuldade na Realização das Atividades Online, por Nível de Participação no Fórum.

Gráfico 14 - Distribuição das Notas Atribuídas pelos Alunos em Relação à Contribuição do Fórum para o Aprendizado, por Falta de Tempo e por Nível de Participação no Fórum .......124

Gráfico 15 - Distribuição das Notas Atribuídas pelos Alunos em Relação ao Chat.............................127

Gráfico 16 - Distribuição das Notas Atribuídas pelos Alunos para a Contribuição do Chat no Aprendizado, por Nível de Interesse em Gestão de Pessoas.

Gráfico 17 - Distribuição das Notas Atribuídas pelos Alunos em relação à Contribuição do Fórum e do Chat para o Aprendizado.

Gráfico 18 - Distribuição das Notas Atribuídas pelos Alunos em Relação à Postura dos Colegas, por Avaliação da Contribuição do Chat para o Aprendizado

Gráfico 19 - Distribuição das Notas Atribuídas pelos Alunos em Relação à Adequada Substituição da Aula Presencial pela Virtual e à Contribuição do Chat para o Aprendizado............135

Gráfico 20 - Distribuição das Notas Atribuídas pelos Alunos para a Contribuição de Cada Atividade de e-Learning no Aprendizado.

Gráfico 21 - Distribuição das Respostas Atribuídas pelos Alunos sobre o Aspecto de que Mais Gostaram e o de que Menos Gostaram na Experiência com o e-Learning.....

Gráfico 22 - Distribuição das Notas Atribuídas pelos Alunos em relação à Contribuição Geral das Atividades de e-Learning para o Aprendizado.

Gráfico 23 - Distribuição das Notas Atribuídas pelo Alunos em Relação à Contribuição Geral do e-Learning para o Aprendizado, por Nível de Participação Online*.. 
Gráfico 24 - Distribuição das Notas Atribuídas pelos Alunos em Relação à Contribuição do e-Learning para o Aprendizado e ao Nível de Motivação

Gráfico 25 - Distribuição das Notas Atribuídas pelos Alunos em Relação à Contribuição Geral do e-Learning e das Notas em Relação à Contribuição dos Testes Auto-corrigidos e do WebQuest.

Gráfico 26 - Distribuição das Notas Atribuídas pelos Alunos para o Atendimento das Expectativas em Relação às Atividades Realizadas e o Nível de Interesse em Participar de Outra Disciplina com Atividades de e-Learning

Gráfico 27 - Distribuição das Notas Atribuídas pelos Alunos para a Contribuição do e-Learning no Desenvolvimento da Auto-aprendizagem....

Gráfico 28 - Distribuição das Notas Atribuídas pelos Alunos em Relação ao Desenvolvimento da Auto-aprendizagem, por Nota Atribuída em Relação à Contribuição do e-Learning para o Aprendizado.....

Gráfico 29 - Distribuição das Notas Atribuídas pelos Alunos para a Contribuição do e-Learning no Desenvolvimento da Pesquisa na Internet

Gráfico 30 - Distribuição das Notas Atribuídas pelos Alunos em Relação à Contribuição do e-Learning no Desenvolvimento de Competências Sociais...

Gráfico 31 - Distribuição das Notas Atribuídas pelos Alunos em Relação à Contribuição do Chat para o Aprendizado, por Tipo Sensação/Intuição, Considerando apenas os Alunos do Tipo Introversão.

Gráfico 32 - Distribuição das Notas Atribuídas pelos Alunos em Relação à Adequada Substituição da Aula Presencial pela Virtual, por Tipo Sensação/Intuição, Considerando apenas os Alunos do Tipo Extroversão. 


\section{LISTA DE ABREVIATURAS E SIGLAS}

AIE Associação Internacional de Educação Continuada

CAI Instrução Apoiada por Computador (Computer Assisted Instruction)

CBT Treinamento Baseado no Computador (Computer Based Training)

CFA Conselho Federal de Administração

CMC Comunicação Mediada por Computador (Computer Mediated Communication)

CNE Conselho Nacional de Educação

DCN Diretrizes Curriculares Nacionais

DP Desvio Padrão

EAD Educação a Distância

FAAB Faculdade de Administração de Brasília

FEA Faculdade de Economia, Administração e Contabilidade da USP

FIA Fundação Instituto de Administração

FUVEST Fundação Universitária para o Vestibular

IME Instituto de Matemática e Estatística da USP

MEC Ministério da Educação

RH Recursos Humanos

SEED Secretaria de Educação a Distância do Ministério da Educação

USP Universidade de São Paulo

Nomenclatura dos Tipos Psicológicos:

$\begin{array}{llll}\text { I } & \text { Introversão } & \text { E } & \text { Extroversão } \\ \text { S } & \text { Sensação } & \text { N } & \text { Intuição } \\ \text { T } & \text { Pensamento } & \text { F } & \text { Sentimento } \\ \text { J } & \text { Julgamento } & \text { P } & \text { Percepção }\end{array}$




\section{APRESENTAÇÃO}

Durante minha experiência profissional, tive a oportunidade de me envolver com $e$ learning $^{1}$ em diferentes contextos; isto me levou a refletir sobre o potencial de utilização dessa metodologia no processo de ensino-aprendizagem e, mais especificamente, no processo de desenvolvimento de competências do administrador. De forma geral, a realização do curso de graduação em Administração na FEA/USP, concluído em 1996, assim como a atuação como profissional de administração, em consultoria e em empresas, contribuíram para esse enfoque.

Entre as experiências relacionadas com e-learning, primeiramente, participei como aluna de treinamentos disponibilizados pela Accenture (antiga Andersen Consulting), que incluíam pacotes de softwares (CBTs - Computer Based Trainings) e curso realizado na Internet, também com interação através de teleconferências via telefone. Em um segundo momento, participei de um treinamento no Centro de Treinamento da Accenture, em Chicago (1998), onde tive contato com algumas metodologias para o desenvolvimento de cursos, entre elas o Storyboard (simulação das telas de um software de treinamento). Ainda durante este período em que trabalhei na Accenture (1997 a 1999), participei de projetos de implantação de sistemas integrados de gestão com grande envolvimento nas atividades de treinamento, onde foi possível utilizar o e-learning para treinamento de grande número de pessoas, em diversas localidades, com rapidez.

Posteriormente, trabalhando na Vésper (1999 a 2001), empresa do setor de telecomunicações, liderei o projeto de desenvolvimento e implantação do primeiro treinamento da empresa através da Internet. O objetivo dessa iniciativa foi desenvolver um curso de integração para os novos funcionários, a ser disponibilizado nas dezessete filiais, liberando os profissionais de Recursos Humanos da tarefa de ministrar uma palestra periodicamente sobre a empresa. Durante esse projeto, surgiram dificuldades relacionadas com a contratação e gestão de fornecedores e foi possível perceber o desconhecimento existente no mercado quanto às melhores práticas do e-learning.

\footnotetext{
${ }^{1}$ E-learning é uma modalidade de educação a distância que utiliza a Internet para a sua operacionalização. Mais detalhes deste conceito serão comentados no capítulo dois - revisão bibliográfica.
} 
Dessa forma, quando ingressei no programa de pós-graduação do Departamento de Administração da FEA/USP (2001), escolhi o e-learning como tema para minha pesquisa. Nos últimos dois anos, período em que estive cumprindo os créditos, participei de alguns projetos relacionados ao tema que, em conjunto com as disciplinas realizadas, contribuíram de forma decisiva no delineamento do meu projeto. De forma complementar, a participação em Congressos e Eventos específicos de Educação a Distância e de Administração possibilitou minha atualização em relação às últimas tendências e melhores práticas existentes.

Um dos projetos de que participei foi desenvolvido pela Fundação Instituto de Administração (instituição conveniada com a FEA/USP), em parceria com a Editora Abril, e teve como objetivo o desenvolvimento de 4 cursos de e-learning. Meu envolvimento concentrou-se na assistência a um dos professores no desenvolvimento do conteúdo do curso. Essa experiência demonstrou a importância da fase de planejamento e construção do curso e os desafios de gestão de um projeto dessa natureza, incluindo aspectos como planejamento, parcerias, equipes multidisciplinares, direitos autorais, entre outros.

Em outro momento, quando cursei a disciplina "Educação Corporativa \& Gestão da Aprendizagem e do Conhecimento Organizacional", oferecida pelo Programa de PósGraduação em Administração da FEA/USP, participei da criação e implementação do ambiente de e-learning para os alunos desse curso, utilizando o software WebCT, em um modelo semelhante ao utilizado na pesquisa, objeto deste trabalho. Ao final do curso, foi aplicado um questionário de avaliação das atividades realizadas e foram obtidas sugestões de melhoria, sendo algumas implementadas nesta pesquisa.

Por fim, dando continuidade ao envolvimento em atividades de e-learning na FEA, participei do levantamento de atividades de educação a distância realizadas pelos professores da Faculdade, promovido pelo Laboratório de Ensino e Aprendizagem da FEA/USP. Nesse processo, foi possível identificar como alguns professores estão utilizando o de e-learning para complementar o ensino da administração.

A partir dessa trajetória profissional, emerge o foco deste trabalho: a contribuição do e-learning para o desenvolvimento de competências do administrador. 


\section{INTRODUÇÃO}

\subsection{O Contexto Atual}

Profundas mudanças no contexto do mundo moderno resultaram em um ambiente de grande turbulência. Entre as principais mudanças é possível citar: a necessidade de “orientação para o cliente", que passou a "ditar as regras", a "globalização dos mercados e da produção" e "o advento da economia baseada em conhecimento" (FLEURY e FLEURY, 2001, p.36).

Essas características do contexto atual determinaram um novo nível de exigência das empresas, decorrente, entre outros fatores, do aumento da concorrência e do aumento da velocidade de inovação. Da mesma forma, os profissionais inseridos no ambiente corporativo passam a ser fonte de vantagem competitiva para a empresa, visto que desempenham um papel fundamental no atendimento a novas demandas do negócio, na implementação de novas estratégias e na geração de inovações; e também passam a enfrentar um outro nível de cobrança, uma atuação relacionada ao conceito de competência. De acordo com ZARIFIAN ${ }^{2}$ (1994 apud FLEURY e FLEURY, 2001) a competência pode ser compreendida como “inteligência prática de situações", indo além das atribuições da tarefa e do estoque de conhecimentos do indivíduo.

Assim, “está aumentando entre as pessoas que já têm alto nível de instrução e ótimo desempenho profissional a percepção de que não estão conseguindo manter-se em dia com as mudanças"; ou seja, as transformações profundas pelas quais a sociedade está passando demandam que a educação seja vitalícia (DRUKER, 2000, p.64). Esse aspecto também é mencionado no Relatório para a UNESCO da Comissão Internacional sobre Educação para o século XXI, visto que "a evolução rápida do mundo exige uma atualização contínua dos saberes" e a educação passa a ocupar "cada vez mais espaço na vida das pessoas" (DELORS, 1999, p.103).

Esse cenário, também, gera um impacto nas instituições de ensino responsáveis pela formação do administrador, que precisam preparar um profissional para atuar nessa nova

\footnotetext{
${ }^{2}$ ZARIFIAN, P. Compétences et organization qualifiante em milieu industriel. In: MINET, Francis, PARLIER, Michel, WITTE, Serge. La Competénce: mythe, construction ou realité? Paris: Liaisons, 1994.
} 
realidade organizacional. De acordo com SILVA, "o maior desafio do administrador do futuro é ser um eterno aprendiz e levar o seu aprendizado para o ambiente das organizações” (1998, p.11).

Esses desafios atuais são mencionados no texto que discute o papel da Universidade e da FEA na atualidade:
Espera-se do Docente e dos programas de graduação que garantam formação específica nas respectivas áreas de conhecimento. Isto implica que, mesmo na graduação, nossos cursos devem refletir a fronteira do conhecimento na área, devem inserir o debate técnico e instrumentalizador, não como um dado pronto e acabado, mas como um processo continuado, capacitando o aluno no processo de aprendizado contínuo. [...] Mais uma vez cabe um desafio enorme para os Docentes. Por um lado o de acompanhar a fronteira do conhecimento traduzindo-o em linguagem útil para o aluno de graduação. Segundo, ser capaz de antecipar as necessidades dos mercados que absorverão os futuros profissionais, sendo isto reconhecidamente difícil em sociedades que se transformam tão rapidamente. Mais uma vez, cabe a focalização na formação básica e na capacitação para o aprendizado contínuo.
O papel instrumentalizador só poderá ser exercido se percebermos como o aluno muda a sua capacidade de comunicação, em especial em face de novas tecnologias de comunicação. O uso da Tecnologia da Informação (TI) e a inserção do aluno e do curso em uma ambientação internacional, ampliada a baixo custo pelo uso da tecnologia, não podem ser ignorados (MARTINS e FLEURY, 2000, p. 9-10).

No contexto da organização, a crescente utilização da tecnologia de informação, da Internet e do e-learning sinaliza a necessidade do administrador estar capacitado para atuar utilizando essas ferramentas. Levando-se em consideração as previsões quanto ao aumento da importância do ciberespaço, "que tende a tornar-se a principal infra-estrutura de produção, transação e gerenciamento econômicos" (LÉVY 1999, p.167), e da presença de equipes de trabalho virtuais, principalmente em empresas globalizadas (PRENCIPE, 2001), cada vez mais a informática torna-se um recurso fundamental para o administrador no desempenho de suas atividades.

Tendo em vista a necessidade de formar um administrador preparado para assumir a responsabilidade por seu próprio aprendizado, de forma a viabilizar sua educação por toda a vida e também preparado para trabalhar utilizando as tecnologias de informação cada vez mais presentes, o e-learning desponta como um componente a ser considerado nesse processo. 


\subsection{Os Objetivos da Pesquisa}

De acordo com FERRARI (1982) a finalidade da pesquisa é tentar conhecer e explicar fenômenos que ocorrem no mundo, incluindo seu funcionamento, estrutura e função, como esses fenômenos se modificam e as possibilidades de controle e orientação.

MATTAR (1999, p. 60) comenta os aspectos que devem ser considerados na definição do objetivo de pesquisa:

- tempo disponível;

- recursos disponíveis;

- acessibilidade aos detentores dos dados;

- disponibilidade dos meios de captação dos dados.

Considerando as questões colocadas por FERRARI e MATTAR, este estudo pretende analisar a contribuição do e-learning, como atividade complementar do curso de graduação, para o desenvolvimento de competências do administrador. Essa discussão será realizada a partir de três objetivos específicos, descritos a seguir:

1. Identificar a contribuição das atividades de e-learning (conteúdo, testes autocorrigidos, WebQuest, Fórum e Chat) para o desenvolvimento de competências técnicas, foco da disciplina Administração de RH I;

2. Analisar a contribuição do e-learning no desenvolvimento de competências de aprendizagem e competências sociais;

3. Discutir a influência do estilo de aprendizagem do aluno na utilização do e-learning para o desenvolvimento de competências do administrador, acima citadas (técnicas, de aprendizagem e sociais).

O primeiro objetivo busca analisar se as atividades de e-learning ajudaram no aprendizado do conteúdo da disciplina pesquisada (Administração de Recursos Humanos I); ou seja, no desenvolvimento de competências técnicas do administrador. Dessa forma, foi pesquisada a opinião dos alunos em relação a dois aspectos: grau de contribuição de cada atividade de e-learning no aprendizado da matéria (Dimensão Competências do Administrador) e grau de satisfação em relação às atividades realizadas (Dimensão Atividades de e-Learning).

Já o segundo objetivo se refere ao potencial de contribuição do e-learning no desenvolvimento de outras competências do administrador, não diretamente relacionadas ao 
conteúdo da disciplina Administração de RH I. Assim, foi pesquisada a opinião do aluno em relação ao nível de contribuição do e-learning no aprimoramento da auto-aprendizagem, pesquisa na Internet, comunicação em ambientes virtuais, participação em discussões e formação de comunidades virtuais.

Por fim, o terceiro objetivo, busca analisar possíveis impactos na contribuição do $e$ learning para o desenvolvimento de competências resultantes do estilo de aprendizagem dos alunos; considerando as competências analisadas nos dois objetivos anteriores (técnicas, de aprendizagem e sociais). Portanto, buscou-se analisar as possíveis relações entre os estilos de aprendizagem e as notas atribuídas pelos alunos sobre a contribuição do e-learning no desenvolvimento de competências.

Para a realização dos objetivos propostos, esta pesquisa foi dividida em dois momentos. Na primeira etapa, foi realizada uma pesquisa bibliográfica sobre os temas Formação do Administrador, Aprendizagem e e-Learning, cujo resultado está apresentado no próximo capítulo (Revisão Bibliográfica). A realização da pesquisa empírica, segunda etapa, consistiu na análise das três dimensões estudadas: Competências do Administrador, Atividades de e-Learning e Estilo de Aprendizagem. Também fez parte da pesquisa a análise de alguns aspectos com potencial de influenciar as dimensões definidas, chamados de variáveis intervenientes: perfil do aluno, grau de satisfação do aluno com aspectos tecnológicos, nível de aproveitamento do curso, grau de satisfação do professor com a utilização do e-learning. A Figura 1, a seguir, apresenta de forma resumida o esquema de realização deste estudo. 
Figura 1 - Esquema do Estudo

PESQUISA BIBLIOGRÁFICA

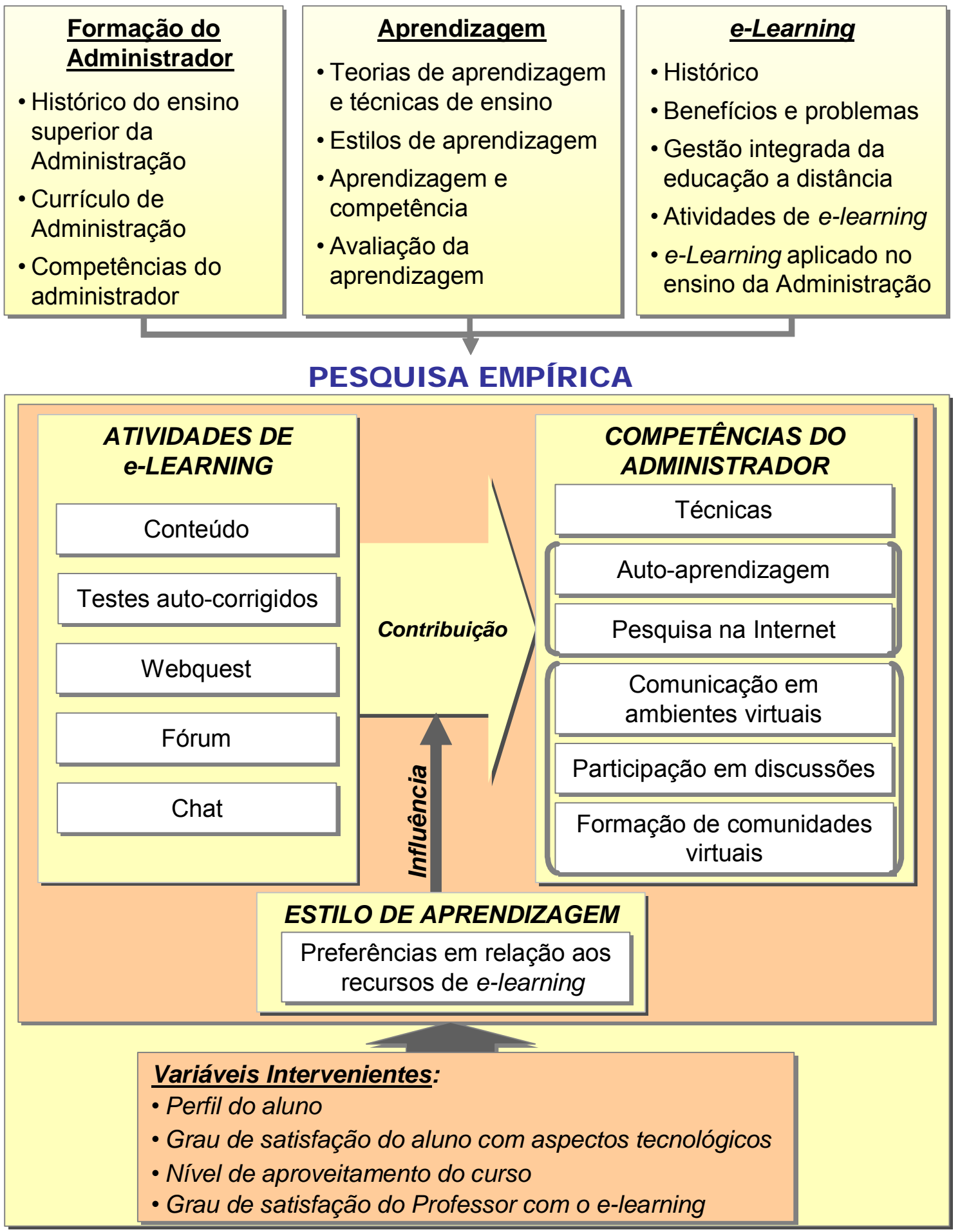




\subsection{A Justificativa da Pesquisa}

A justificativa inicial para realização deste estudo consiste na importância de se estudar modelos de aprendizagem para o desenvolvimento de competências $^{3}$ do administrador.

De acordo com Paulo da Costa LOPES, "os cursos de Administração possuem dificuldade em prover, de maneira adequada ao atual ambiente de negócios, competências essenciais ao exercício profissional" (2002, p. 2). REIGELUTH corrobora, quando discute a necessidade de tornar os métodos de ensino mais eficazes e eficientes, de forma a atender às mudanças crescentes nas tecnologias e sociedade como um todo (1983).

A pesquisa realizada pelo CFA, em 1998, revela que 42\% dos administradores pesquisados consideram "que a educação, a formação, a qualificação e a reciclagem são as armas mais eficientes e eficazes para vencer os desafios futuros".

Ainda com base nos resultados dessa pesquisa (CFA, 1998), "a exploração de didáticas de ensino mais interativas, motivantes e envolventes e que promovam a autoaprendizagem" foram identificadas entre as tendências que provavelmente influenciarão a formação do Administrador nos próximos anos. Essa afirmação é confirmada por BOK (1988), em sua avaliação sobre o ensino superior como um todo.

Considerando estes aspectos, fica clara a necessidade de se estimular uma cultura de auto-aprendizagem, onde a educação a distância pode ser um componente importante para viabilizar a educação continuada durante toda a vida (LIMA, 2000; MAIA, 2001; FORMIGA, 2002). Da mesma forma, a teoria de estilo de aprendizagem também pode contribuir para a melhoria do processo de ensino-aprendizagem, à medida que estimula um aumento da consciência do aluno e professor em relação a esse processo.

Além disso, o e-learning propõe novas formas de educação, que poderiam ser incorporadas para melhorar o ensino presencial. HILTZ (1994) cita algumas das melhorias trazidas pela classe virtual, se comparada ao ensino presencial tradicional:

- Incentivo e apoio ao aprendizado colaborativo ou em grupo;

- Aprendizado ativo, a participação ativa é necessária;

- Ritmo do curso mais ajustado ao aluno do que ao professor;

\footnotetext{
${ }^{3} \mathrm{O}$ foco em competências do administrador é de grande importância, pois se refere à abordagem proposta recentemente nas Diretrizes Curriculares Nacionais (BRASIL, 2002).
} 
- Uso do computador;

- Anotações completas sobre o conteúdo.

De acordo com BERNDT, “com a rapidez do desenvolvimento da rede Internet e outras podemos antever, em um futuro breve, revolucionárias abordagens ao ensinoaprendizagem. Torna-se imperioso que os cursos de administração não só participem deste processo como o liderem dentro de suas instituições" (1996, p. 63).

Ampliando as possibilidades de utilização da educação a distância, em 18 de outubro de 2001, entrou em vigor a Portaria $n^{0} 2253$, que permite às instituições de ensino superior a introdução "na organização pedagógica e curricular de seus cursos superiores reconhecidos, a oferta de disciplinas que, em seu todo ou em parte, utilizem método não presencial", não podendo exceder vinte por cento do tempo previsto para integralização do respectivo currículo ${ }^{4}$.

Por outro lado, de acordo com GODOY (1997b, p. 111), o uso do computador como recurso de ensino ainda é reduzido no ensino superior. Essa ferramenta possui grande potencial para auxiliar o docente na execução do programa, guiando o aluno, disponibilizando materiais, aplicando testes, simulações e casos, disponibilizando relatórios de progresso para acompanhamento dos alunos e armazenando informações.

Adicionado às justificativas apresentadas, está o contexto da organização, que consiste no ambiente de atuação do administrador. A crescente utilização da tecnologia de informação, da Internet e do e-learning nas empresas sinaliza a necessidade de o administrador estar capacitado para desempenhar suas atividades utilizando essas novas ferramentas.

De acordo com LÉVY, o ciberespaço "será em breve o principal equipamento coletivo internacional da memória, pensamento e comunicação" (1999, p. 167). Seguindo essa tendência, de acordo com o Gartner Group, em 2004, 80\% dos trabalhos executados nas atuais companhias globalizadas, serão realizados por times virtuais (PRENCIPE, 2001); crescimento possivelmente resultante da ampliação de áreas de atuação, pressões para redução de prazos na realização de tarefas, ausência do local de trabalho e necessidade de redução de custos envolvidos com deslocamento e viagens.

\footnotetext{
4 Além disso, a oferta dessas disciplinas "deverá incluir métodos e práticas de ensino-aprendizagem que incorporem o uso integrado de tecnologias de informação e comunicação para a realização dos objetivos pedagógicos" e o exame final deverá ser realizado presencialmente (BRASIL, 2001, p. 1).
} 
Do ponto de vista da atuação do administrador, de acordo com SOUKI, ANTONIALLI e SALGADO (2001), a informática é um dos recursos mais importantes para que o processo decisório do administrador ocorra com rapidez e assertividade. Dessa forma, o administrador precisa de um sólido conhecimento interdisciplinar em administração e informática.

Apresentados os aspectos que justificam a aplicação do e-learning para a formação do administrador, é preciso explicar a importância de estudar a melhor forma de utilizar esse método de ensino.

Em primeiro lugar, a pesquisa sobre novas estratégias e tecnologias na educação, como o e-learning, contribui para o desenvolvimento dos métodos de ensino em geral, à medida que estes são revistos e atualizados. De acordo com BOK, "os esforços para melhorar o aprendizado não podem avançar muito longe, a não ser por acaso, a menos que as universidades encontrem um método de determinar quais as iniciativas que obtêm êxito e quais as que não obtêm” (1988, p. 203). Dessa forma, o esforço de investigar o processo de ensinar e aprender e de avaliar seus efeitos auxiliará os professores e dirigentes a "fazerem opções mais seguras sobre métodos de instrução, emprego de tecnologia" e outras questões (BOK, 1988, p. 204).

Além disso, faltam pesquisas estruturadas sobre e-learning. De acordo com HARA e KLING (1999), os estudos sobre ensino a distância mediado por computador precisam ser mais sistemáticos e críticos.

O estudo das atividades de e-learning, também, pode ser justificado pela conclusão de YONEZAWA (2000), que, em sua tese de doutorado, identificou o conteúdo e a forma do curso como fatores críticos de sucesso.

ARBAUGH (2000) complementa, afirmando que tem sido observado um rápido crescimento do número de cursos oferecidos por faculdades através da Internet, embora o conhecimento ainda seja limitado em relação ao que torna esses cursos efetivos em termos de experiências de aprendizado.

Além disso, de acordo com Jonathon Levy, vice-presidente da Harvard Business School Publishing Corporation, o e-learning está sendo redescoberto e redirecionado, após ter fracassado nos moldes utilizados no final dos anos 90, quando se verificou a ineficiência de literalmente transferir cursos para o computador. "Mesmo assim, [o e-learning] ainda está 
longe de ser utilizado em sua potência máxima como uma ferramenta de fato revolucionária capaz de reinventar o aprendizado" (CAMPOS, 2002).

Especificamente no caso da utilização de e-learning na empresa, a pesquisa sobre o potencial do e-learning na América Latina (Relatório 2001), realizada pela PricewaterhouseCoopers, demonstra um grande potencial de desenvolvimento: $40 \%$ das 190 empresas pesquisadas expressaram interesse estratégico em e-learning, embora somente $20 \%$ estejam utilizando essa modalidade de educação a distância de forma significativa. Corroborando com esses resultados, a pesquisa realizada no Brasil com 100 executivos de empresas de vários setores indicou que $46 \%$ das empresas pesquisadas utilizam ferramenta de e-learning, sendo que desses $61 \%$ pretendem estender sua utilização (O ENSINO..., 2003). A crescente utilização do e-learning no ambiente corporativo indica outra justificativa deste trabalho, uma vez que os resultados podem sugerir caminhos para a utilização do e-learning também nas empresas, apesar do foco desta pesquisa ser o aluno de graduação.

Resumindo, a justificativa para a realização deste estudo está fundamentada, principalmente, na necessidade de aprimorar os métodos de ensino para o desenvolvimento de competências do administrador, na necessidade de estimular uma cultura de autoaprendizagem, na possibilidade de utilizar técnicas não presenciais até $20 \%$ do curso, na crescente utilização das tecnologias de informação no ambiente corporativo e na clara necessidade de se estudar melhores formas de utilização do e-learning, considerando o recente desenvolvimento dessa metodologia, seu potencial de crescimento e os desafios ainda sem soluções estruturadas. 


\section{REVISÃO BIBLIOGRÁFICA}

Com base nos objetivos propostos, a revisão bibliográfica deste trabalho foi desenvolvida em três pilares:

a) Formação do Administrador: apresentação breve do histórico do ensino superior da Administração e seu currículo e discussão das competências do administrador;

b) Aprendizagem: discussão das teorias de aprendizagem, das técnicas de ensino, do estilo de aprendizagem, da questão do desenvolvimento de competências e da avaliação da aprendizagem;

c) e-Learning: incluindo um breve histórico, seus benefícios e problemas, a gestão integrada da educação a distância, as atividades de $e$-learning e experiências de $e$ learning no ensino da Administração.

Tendo em vista a abrangência de cada um desses temas, não é viável abordá-los de forma detalhada. Desse modo, neste capítulo estão apresentados somente os elementos mais importantes para esta pesquisa.

\subsection{A Formação do Administrador}

O desafio atual de formação do administrador é preparar um profissional para atuar como "agente transformador, capaz de ajustar-se com rapidez aos avanços da ciência e da tecnologia no estabelecimento de uma nova ordem. O impacto da tecnologia na sociedade exige uma permanente atualização das ações educacionais e uma constante reconstrução do seu cotidiano" (GUERRA, 2001, p. 6).

Em coerência com a necessidade de constante atualização e revisão do processo educativo, a Lei 9131/95 instituiu o Conselho Nacional de Educação (CNE), órgão capaz de orientar e supervisionar o funcionamento do sistema de ensino superior, e o Exame Nacional de Cursos ("provão"), procedimento para avaliação dos cursos de graduação (MARTINS, 1989). Em 1999, 431 cursos de Administração participaram do ENC, envolvendo 37.850 graduandos (ANDRADE, LIMA e TORDINO, 2001).

Pesquisas também constituem outra fonte de informações para discutir melhorias dos cursos de Administração. Em 1998, o CFA realizou a pesquisa "Perfil, Formação e 
Oportunidades de Trabalho do Administrador Profissional", através da realização de 20 dinâmicas de grupo e da aplicação de 783 questionários com administradores profissionais, professores universitários e empregadores de diferentes regiões do Brasil. De acordo com essa pesquisa, dos 387 administradores pesquisados, 49\% avaliaram positivamente a formação universitária que concluiram, embora criticassem a formação universitária do administrador, enfatizando

[...] a formação prática insuficiente, a desatualização somada à superficialidade dos conteúdos transmitidos, a falta de sintonia entre o ensino e as necessidades do mercado, a ênfase na formação geral em detrimento da formação profissional e a ilusão de sucesso profissional fácil (CFA, 1998).

Também durante essa pesquisa (1998), foram identificadas as deficiências na formação do Administrador, do ponto de vista dos 256 professores pesquisados. Os resultados obtidos, apesar de não trazerem novidades, reforçam os aspectos que precisam ser aprimorados: a desarticulação entre a teoria e a prática $(22,4 \%)$, a falta de sintonia entre o curso e as exigências do mercado (17\%), o reduzido espaço reservado para a pesquisa (15\%), a desmotivação, o desinteresse e a apatia dos estudantes (14,6\%), o perfil do ingresso (13\%) e a falta de unidade da grade curricular $(12,6 \%)$. Considerando essas questões, foram citados alguns recursos didáticos que deveriam ser exaustivamente explorados: estágio supervisionado (40\%), programas de consultoria (66,7\%), visitas às empresas $(60 \%)$, jogos de empresa (76\%) e elaboração de casos (74\%); além da ênfase em didáticas interativas.

Com o objetivo de compreender melhor os desafios atuais dos cursos de Administração, a seguir, são apresentados, de forma resumida, o histórico do ensino superior da Administração, as mudanças do currículo mínimo de Administração e as competências que integram o perfil esperado do administrador.

\subsubsection{O Histórico do Ensino Superior da Administração}

A criação e evolução dos cursos de Administração, no Brasil, estão fortemente relacionadas aos processos de desenvolvimento do país. Na medida em que crescia o uso da técnica maquinária ou organizatória, também crescia a necessidade de profissionais cada vez mais especializados nas funções administrativas, para atuar na formação da máquina burocrática (COVRE, 1981). 
Com o objetivo de apresentar de forma resumida o histórico, a seguir são mencionados alguns dos principais marcos do ensino superior da Administração, em seqüência cronológica.

De acordo com ANDRADE (2002), atual Presidente do CFA, o primórdio da Administração no Brasil se deu em 23 de junho de 1931, com a fundação do "Instituto de Organização Racional do Trabalho", em São Paulo. Essa organização, mais conhecida pela sigla "IDORT", estava preocupada com os aspectos organizacionais e de formação profissional, tendo articulado a implantação do taylorismo no Brasil. O IDORT também foi responsável, em 1942, pela criação do Serviço Nacional de Aprendizagem Industrial - SENAI (IDORT, 2002).

Em 1944, é criada a Fundação Getúlio Vargas, através do Decreto-lei n 6.693 , com o objetivo de estudar a organização racional do trabalho e de preparar pessoas para a administração pública e privada (COVRE, 1981).

Dois anos depois (1946), a Faculdade de Economia, Administração e Contabilidade da Universidade de São Paulo (FEA-USP) é fundada, com o nome Faculdade de Ciências Econômicas e Administrativas, oferecendo inicialmente bacharelado em ciências econômicas e ciências contábeis e também contribuindo para o ensino e pesquisa em administração (FEA, 2003).

$\mathrm{Na}$ década de 50, são criadas duas escolas de Administração na Fundação Getúlio Vargas. Em 1952, é criada a Escola Brasileira de Administração Pública e de Empresas da Fundação Getúlio Vargas (EBAPE-FGV), no Rio de Janeiro. Em 1954, é criada a Escola de Administração de Empresas de São Paulo (EAESP-FGV), onde, em 1955, é aberta a primeira turma de graduação em Administração.

Em 1964, são estabelecidos os cursos de Administração de Empresas, Ciências Atuariais e Administração Pública da FEA-USP, através da Portaria GR no 8 de 17/01/64 (PAIVA, 2002).

Outro marco importante na evolução do ensino da Administração foi a criação da profissão de Técnico de Administração, através da assinatura da Lei $n^{\circ} 4769$, de 9 de setembro de 1965 (ANDRADE, 2002); seguida pela criação do primeiro currículo mínimo de administração, no ano 1966 (BERNDT, 1996), tema abordado no próximo tópico.

A partir de então, os cursos de Administração passam a se expandir de forma rápida e intensa (COVRE, 1981). Essa tendência também foi observada no ensino superior brasileiro como um todo; de acordo com MARTINS, "o período de maior intensidade de matrículas 
ocorreu durante os anos 60, quando a taxa de crescimento foi de $218 \%$. Na década seguinte, esse ritmo permanece também bastante elevado, uma vez que foi de 208\%" (1989, p. 66). O Quadro 1 demonstra essa expansão no caso dos cursos de Economia e Administração do Estado de São Paulo.

Quadro 1 - Número de Escolas de Economia e Administração, por Período, no Estado de São Paulo

\begin{tabular}{lc}
\hline \multicolumn{1}{c}{ Períodos } & $\mathbf{N}^{\mathbf{0}}$ Escolas \\
\hline Até 1940 & 3 \\
De $1940 / 50$ & 9 \\
De $1951 / 60$ & 14 \\
De $1961 / 70$ & 38 \\
De $1970 / 80$ & 66 \\
\hline
\end{tabular}

Fonte: Adaptado de COVRE (1981, p.80).

De acordo com MARTINS (1989), na década de 80 observou-se um crescimento de 16\% no número de matrículas do ensino superior como um todo e, no início dos anos 90, de $3,5 \%$, representando uma certa estagnação da expansão, se comparado às décadas anteriores. A partir de 1994, são verificados sinais de recuperação, sendo que, em 2001, foi identificado um crescimento de 43\% em relação a 1998 (INEP NOTÍCIAS, 2002). A recente expansão no número de ingressantes no ensino superior pode ser compreendida como conseqüência do aumento do número de concluintes do ensino médio (INEP NOTÍCIAS, 2001); etapa considerada gargalo para o crescimento do sistema educacional brasileiro (MARTINS, 1989).

O curso de Administração, em 1998, ocupou o segundo lugar na relação dos cursos com maior número de alunos, com 257.408 matrículas (o curso de Direito foi primeiro lugar); e a mesma posição em relação ao número de concluintes (31.630 alunos).

Em 2001, o Censo da Educação Superior, divulgado pelo INEP, mapeou 1.009 cursos de graduação em Administração no Brasil, dando conta de 356.156 matrículas (INEP, 2002).

\subsubsection{O Currículo de Administração}

A concepção do currículo mínimo teve como objetivos: facilitar transferências de alunos entre instituições; fornecer diploma profissional para o exercício da profissão; 
assegurar uniformidade mínima; permitir a fixação da duração mínima, média ou máxima do curso; observar normas gerais, assegurando "igualdade de oportunidades" (NICOLINI, 2002).

Nesse contexto, com o objetivo de atender à exigência da Lei de Diretrizes e Bases, o primeiro currículo mínimo do Curso de Administração surge em 1966, regulamentado pelo Conselho Federal de Educação (substituído em 1995 pelo Conselho Nacional de Educação), para fixar o conteúdo mínimo e a duração do curso (NICOLINI, 2002).

Após 27 anos, o atual currículo mínimo (de 1993) entra em vigor. BERNDT (1996) chama a atenção para as semelhanças entre o currículo antigo e o novo. Ambos os currículos propõem ênfase na metodologia de ensino, ao invés das matérias. Essas, por sua vez, foram consideradas semelhantes, apesar do aprimoramento de alguns nomes, algumas inclusões e a redução da importância da área de Direito. A carga horária passa a ser de 3.000 horas, já incluído o estágio supervisionado, ao invés de 2.700 horas sem o estágio; e o tempo mínimo de integralização de 4 anos é mantido.

De acordo com COMINI e LIMA, os principais aspectos do novo currículo incluem: “a elevação da duração mínima do curso para 3.000 horas-aula, a flexibilidade dada às instituições na distribuição de 960 horas-aula (32\% da duração total) de matérias eletivas e a separação entre matérias de formação básica e instrumental de matérias de formação profissional"' (1996, p. 139).

NICOLINI afirma que a maior novidade do novo currículo "é a tentativa de mudança da ênfase na formação", de tecnicista para generalista, assumindo a Administração como uma “ciência social aplicada" (2002, p. 5).

De acordo com BERNDT (1996), os dois currículos podem ser considerados como guia, cabendo à instituição a missão de desenvolver um bom curso, formulando e implementando uma proposta pedagógica adequada.

Um levantamento junto a 99 escolas de Administração do Brasil foi realizado por COMINI e LIMA (1996), com o objetivo de analisar os resultados da reestruturação curricular. A pesquisa mostrou que 50\% das escolas aproveitaram a revisão do currículo para rever os objetivos do curso. Com relação às mudanças curriculares, as disciplinas de formação profissionalizante aumentaram sua participação no total de horas-aula do currículo novo, resultando em redução da carga horária das disciplinas de formação básica. Os fatores facilitadores do processo de implementação do novo currículo mais mencionados foram a “necessidade e pressão para a mudança e a participação dos docentes"; enquanto que os 
fatores de restrição destacados foram a "resistência dos docentes, dificuldade de ajustes de carga horária e dificuldade de adaptação da grade curricular" (COMINI e LIMA, 1996, p. 146).

Apesar do aumento da flexibilidade decorrente das mudanças realizadas, o currículo mínimo continuava limitando a atuação das Instituições de Ensino Superior. De acordo com Parecer do Conselho Nacional de Educação,

\footnotetext{
os currículos mínimos profissionalizantes, rigidamente concebidos na norma, para serem observados nas instituições, não mais permitiam o alcance da qualidade desejada segundo a sua contextualização no espaço e tempo. Ao contrário, inibiam a inovação e a diversificação na preparação ou formação do profissional apto para a adaptabilidade (BRASIL, 2002, p. 2).
}

Em 1995, é atribuída à Câmara de Educação Superior do Conselho Nacional de Educação competência para a elaboração do projeto de Diretrizes Curriculares Nacionais DCN, com o objetivo de "servir de referência para as instituições na organização de seus programas de formação, permitindo flexibilidade e priorização de áreas de conhecimento na construção dos currículos plenos" (BRASIL, 2002).

De acordo com NICOLINI (2002), a grande evolução ocorrida está na introdução das Diretrizes Curriculares, possibilitando a criação de propostas diferenciadas de formação e a definição do perfil do profissional a ser formado e, em seguida, das competências a serem desenvolvidas. "Evoluiu-se, então, da qualificação obrigatória ditada pelo currículo mínimo para a formação de competências, com grande grau de liberdade" (NICOLINI, 2002, p. 13).

Como resultado dessa maior flexibilização, as Instituições de Ensino Superior têm a oportunidade de vincular seu projeto pedagógico à abordagem de competências, possibilitando a formação de administradores mais preparados para lidar com os desafios que se apresentam.

\subsubsection{As Competências do Administrador}

Antes de iniciar a discussão sobre as competências do administrador, é importante esclarecer o conceito de competência. Para tanto, foi escolhida a definição proposta por FLEURY \& FLEURY: “um saber agir responsável e reconhecido, que implica mobilizar, integrar, transferir conhecimentos, recursos, habilidades, que agreguem valor econômico à 
organização e valor social ao indivíduo" (2001, p. 21). A Figura 2 apresenta de forma esquemática essa definição, incluindo os verbos associados às competências do profissional.

Figura 2 - Competências como fonte de valor para o indivíduo e para a organização

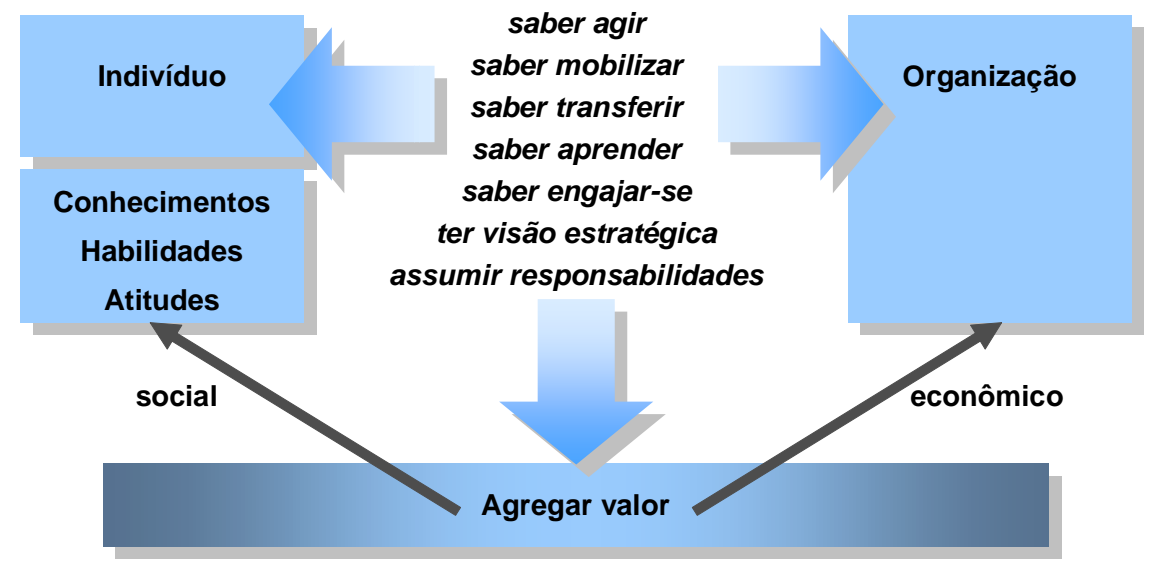

Fonte: FLEURY e FLEURY (2001, p. 21).

DUTRA (2001) complementa esse conceito ao definir a noção de entrega, ou seja, a competência está vinculada à capacidade de entrega do indivíduo, considerando as necessidades da organização.

Como esta pesquisa está voltada para a Instituição de Ensino Superior (IES) formadora de futuros administradores, será utilizado na pesquisa empírica o conceito de Competências de Formação, proposto por AMATUCCI em sua tese de doutorado sobre o perfil do administrador brasileiro:

Ser competente é saber agir. A competência é, portanto, a ação com consciência e 'conhecimento de causa'. Competências de Formação são atributos ou qualidades humanas, obtidas por aprendizagem, do profissional que a Instituição de Ensino Superior deseja formar, tendo em vista a ação na situação de trabalho futura. Atribuir competências a um indivíduo visa torná-lo competente, isto é, pronto para a ação consciente e com conhecimento de causa (2000, p. 85).

Considerando que o conceito proposto por AMATUCCI (2000) foi adaptado de autores franceses, este está totalmente alinhado com o conceito desenvolvido por FLEURY e FLEURY (2001). Apesar disso, é importante reforçar a principal diferença da Competência de Formação em relação aos conceitos utilizados na literatura e nas empresas, visto que esse trata de ações em seu estado potencial ao invés da ação realizada no contexto do trabalho. Assim, a competência de formação constitui uma experiência inicial do aluno, se manifestando como um "saber agir" no ambiente acadêmico. Esse saber agir se transformará realmente numa "entrega" nos ambientes profissionais em que eles desejarem se inserir. 
FLEURY \& FLEURY (2001) propõem a categorização das competências do indivíduo em três blocos, a partir de uma visão sistêmica:

- Competências de Negócio: relacionadas à compreensão do negócio, seus objetivos na relação com o mercado, clientes e concorrentes; compreensão do ambiente político e social; capacidade de planejamento. Exemplos: conhecimento do negócio, orientação para o cliente;

- Competências Técnico-profissionais: específicas de determinada operação, ocupação ou atividade. Exemplos: desenho técnico, conhecimento do produto, finanças. Também faz parte das competências técnico-profissionais a atualização constante dos conhecimentos e a disponibilização de novos, além da sua utilização na realização das atividades.

- Competências Sociais: necessárias para interagir com as pessoas. Exemplos: comunicação, negociação, mobilização para mudança, sensibilidade cultural, trabalho em equipe.

Com base na revisão bibliográfica realizada, foi possível identificar competências que devem ser desenvolvidas na formação do administrador, conforme proposta de vários autores.

Para iniciar essa discussão, são apresentadas as competências e habilidades que os cursos de graduação de Administração devem formar em seus profissionais, de acordo com o parecer aprovado do CNE sobre as Diretrizes Curriculares:

- reconhecer e definir problemas, equacionar soluções, pensar estrategicamente, introduzir modificações no processo produtivo, atuar preventivamente, transferir e generalizar conhecimentos e exercer, em diferentes graus de complexidade, o processo da tomada de decisão;

- desenvolver expressão e comunicação compatíveis com o exercício profissional, inclusive nos processos de negociação e nas comunicações interpessoais ou intergrupais;

- refletir e atuar criticamente sobre a esfera da produção, compreendendo sua posição e função na estrutura produtiva sob seu controle e gerenciamento;

- desenvolver raciocínio lógico, crítico e analítico para operar com valores e formulações matemáticas presentes nas relações formais e causais entre fenômenos produtivos, administrativos e de controle, bem assim expressandose de modo crítico e criativo diante dos diferentes contextos organizacionais e sociais; 
- ter iniciativa, criatividade, determinação, vontade política e administrativa, vontade de aprender, abertura às mudanças e consciência da qualidade e das implicações éticas do seu exercício profissional;

- desenvolver capacidade de transferir conhecimentos da vida e da experiência cotidianas para o ambiente de trabalho e do seu campo de atuação profissional, em diferentes modelos organizacionais, revelando-se profissional adaptável (BRASIL, 2002, p. 13).

De acordo com BASTOS, o "comprometimento com a profissão pode ser visto como elemento crítico para o engajamento do profissional em cursos de ação que lhes garantam lidar com a turbulência do momento presente" (1996, p. 32).

Em 1995, o CFA - Conselho Federal de Administração realizou a pesquisa "Perfil do Administrador e Mercado de Trabalho". O levantamento com 747 administradores respondentes identificou, a partir de uma lista de 31 itens, os atributos/ habilidades do administrador que foram considerados "muito importantes", são eles: responsabilidade, liderança, iniciativa, capacidade de trabalho em equipe, tomada de decisões, criatividade, comunicação pessoal, honestidade, autoconfiança e planejamento (BERNDT, 1996).

FLEURY (2001) e DUTRA (2001) procuraram, em sua proposta conceitual sobre competência, ir além das definições tradicionais de competências: somatória de conhecimentos, habilidades e atitudes, desenvolvidas por McCLELLAND 5 (1990 apud FLEURY e FLEURY, 2001) e seus seguidores na década de 80. As pesquisas realizadas pela ANGRAD (1996) e pelo CFA (1998), citadas a seguir, se prendem ao conceito tradicional de competência.

A Pesquisa "PHAD - Perfil e Habilidades do Administrador", realizada pela ANGRAD (Associação Nacional dos Cursos de Graduação em Administração), em 1996, com 145 Coordenadores de Curso de Graduação em Administração, identificou a importância de itens pré-definidos em relação ao perfil e habilidades do administrador.

Com relação ao perfil, o aspecto considerado mais importante foi a "formação humanística e visão global que o habilite a compreender o meio social, político, econômico e cultural onde está inserido e a tomar decisões em um mundo diversificado e interdependente”. Seguindo a mesma linha, a habilidade considerada mais importante foi a "demonstração da

\footnotetext{
${ }^{5}$ McClELLAND, D. C.; SPENCER, L. M. Competency assessment methods: history and state of the art. Boston Hay: McBer Research Press, 1990.
} 
compreensão do todo administrativo, de modo integrado, sistêmico e estratégico, bem como de suas relações com o ambiente externo"; seguida da "utilização de raciocínio lógico, crítico e analítico [...]", em segundo lugar e da "comunicação interpessoal e expressão correta nos documentos [...]", em terceiro lugar (ANGRAD, 1996).

Dentre os resultados obtidos na pesquisa "Perfil, Formação e Oportunidades de Trabalho do Administrador Profissional”, realizada pelo CFA em 1998, está o perfil ideal do administrador profissional, que tende a um modelo de formação mais pragmático, enfatizando as habilidades e as atitudes em detrimento do conhecimento:

- Conhecimentos: conhecimento em informática, em idiomas, em planejamento e conhecimento sistêmico da empresa.

- Habilidades: saber trabalhar em equipe, capacidade de planejar, capacidade para tomar decisão, capacidade para aprender, capacidade de comunicação verbal e escrita, capacidade de negociação, capacidade de assumir riscos e visão articulada das várias áreas da empresa.

- Atitudes: ter espírito empreendedor, motivar a equipe, ser ético, demonstrar entusiasmo pelo trabalho, comprometimento com a empresa, pré-disposição para trabalhar muitas horas.

Essa pesquisa também identificou os principais atributos dos egressos dos Cursos de Administração, segundo a perspectiva dos 300 empregadores pesquisados: dispor de um diploma universitário (27\%); estar atualizado (26\%); dominar temas relevantes (24\%); dispor de uma visão geral e articulada da empresa (23\%); aprender fácil e rápido (19\%).

AMATUCCI define os atributos do administrador que "qualquer perfil, de qualquer IES [Instituição de Ensino Superior], de qualquer lugar do planeta deveria, nos próximos dez anos, [...] conter" (2000, p. 128), dentre eles é possível citar: aprender a aprender; aprender rapidamente a operar sistemas integrados, atualizar-se em assuntos de Administração; comunicar-se competentemente.

BASTOS (1996) observa a necessidade da atualização constante dos profissionais e das organizações, de forma a acompanhar a aceleração na produção de conhecimentos e tecnologias, fatores críticos para a sobrevivência. O autor, também, comenta os outros aspectos que compõem o perfil "ideal" esperado dos novos profissionais: flexibilidade, criatividade, adaptabilidade, visão abrangente e formação cultural. 
Nesse contexto, a capacidade de aprender continuamente torna-se uma condição para o crescimento profissional, exigindo uma mudança na postura do administrador em relação ao aprendizado (WICK e LEÓN, 1993). O Quadro 2, a seguir, ao comparar as percepções dos administradores do passado com aquelas que deveriam ser adotadas pelos administradores do futuro, reforça a necessidade de o profissional assumir a responsabilidade pelo próprio aprendizado e desenvolvimento.

\section{Quadro 2 - Visão dos Administradores em Relação à Aprendizagem}

$\begin{array}{cc}\text { OS ADMINISTRADORES DO } & \text { OS ADMINISTRADORES DO } \\ \text { PASSADO } & \text { FUTURO }\end{array}$

- Esperavam para ser ensinados

- Procuram deliberadamente aprender

- Achavam que o aprendizado ocorria principalmente na sala de aula

- Reconhecem o poder do aprendizado decorrente da experiência de trabalho

- Responsabilizavam o chefe pela própria carreira

- São responsáveis pela própria carreira

- Não eram considerados responsáveis pelo próprio desenvolvimento

- Assumem a responsabilidade pelo próprio desenvolvimento

- Percebiam a educação como completa ou precisando de pequenos ajustes

- Não percebiam a ligação entre o aprendizado e os resultados do negócio

- Consideram a educação como um esforço contínuo e para toda a vida

- Percebem como o próprio aprendizado afeta os negócios

- Deixavam o aprendizado a cargo da intuição

- Decidem intencionalmente o que aprender

Fonte: WICK e LEÓN (1993, p. 42, tradução da autora).

MORAES corrobora com essa idéia, afirmando que o "perfil do homem atual deve estar pautado no aprender a aprender, na educação continuada, permanente, sabendo pensar, fazendo funcionar" (1998, p. 2). De acordo com a autora, os projetos pedagógicos das instituições de ensino devem contemplar as características da cultura facilitadora da criação de competências, que inclui aspectos como: a disposição para o aprender a aprender, a inovação do conhecimento e a aquisição de linguagens, ponto de partida para o desenvolvimento cognitivo do aluno. Dessa forma, é importante a criação e formação de uma cultura adequada às exigências do contexto em que o profissional de administração atua. 


\subsection{A Aprendizagem}

De acordo com GAGNÉ, “aprendizagem é uma modificação na disposição ou na capacidade do homem, modificação essa que pode ser retida e que não pode ser simplesmente atribuída ao processo de crescimento" (1974, p. 3). GAGNÉ (1974) complementa descrevendo que a aprendizagem se manifesta como uma alteração no comportamento ou na disposição, que, conforme o caso, pode ser atitude, interesse ou valor.

O conceito proposto por BIGGE é igual, em sua essência, ao apresentado anteriormente, apesar de utilizar termos diferenciados: "a aprendizagem, ao contrário da maturação, envolve uma mudança duradoura no indivíduo vivo, não marcada por sua herança genética. Pode ser uma mudança de 'insights', de comportamento, de percepção ou de motivação, ou ainda uma combinação desse elementos" (1977, p. 1).

KOLB apresenta o conceito de aprendizagem baseado na abordagem vivencial (experiential learning): “Aprendizagem é o processo pelo qual o conhecimento é criado, através da transformação da experiência” (1984, p. 3, tradução da autora).

FLEURY e OLIVEIRA conceituam aprendizagem como "um processo de mudança provocado por estímulos diversos e mediado por emoções que podem ou não produzir mudança no comportamento da pessoa" (2002, p. 134).

Resumindo: a partir dos conceitos apresentados, é possível dizer que aprendizagem é um processo de mudança, provocado por estímulos e mediado por emoções, resultando em uma modificação duradoura no comportamento, na disposição ou em uma combinação de ambos, que não pode ser atribuída à herança genética.

Nos próximos tópicos, serão brevemente discutidos: as teorias de aprendizagem, as técnicas de ensino e suas relações com o e-learning; o conceito e as teorias de estilo de aprendizagem, com foco maior na teoria de Tipos Psicológicos desenvolvida por Carl Gustav Jung e alguns conceitos sobre avaliação da aprendizagem. 


\subsubsection{As Teorias de Aprendizagem e as Técnicas de Ensino}

"De um modo geral, uma teoria é uma tentativa humana de sistematizar uma área de conhecimento, uma maneira particular de ver as coisas, de explicar e prever observações, de resolver problemas" (MOREIRA, 1999, p. 12). O esquema conceitual proposto por MOREIRA (1999) apresenta as teorias mais recentes de aprendizagem, agrupando-as em três grandes enfoques: comportamentalismo, cognitivismo e humanismo (Figura 3).

Figura 3 - Um esquema tentativo para os principais enfoques teóricos à aprendizagem e ao ensino e alguns de seus mais conhecidos representantes

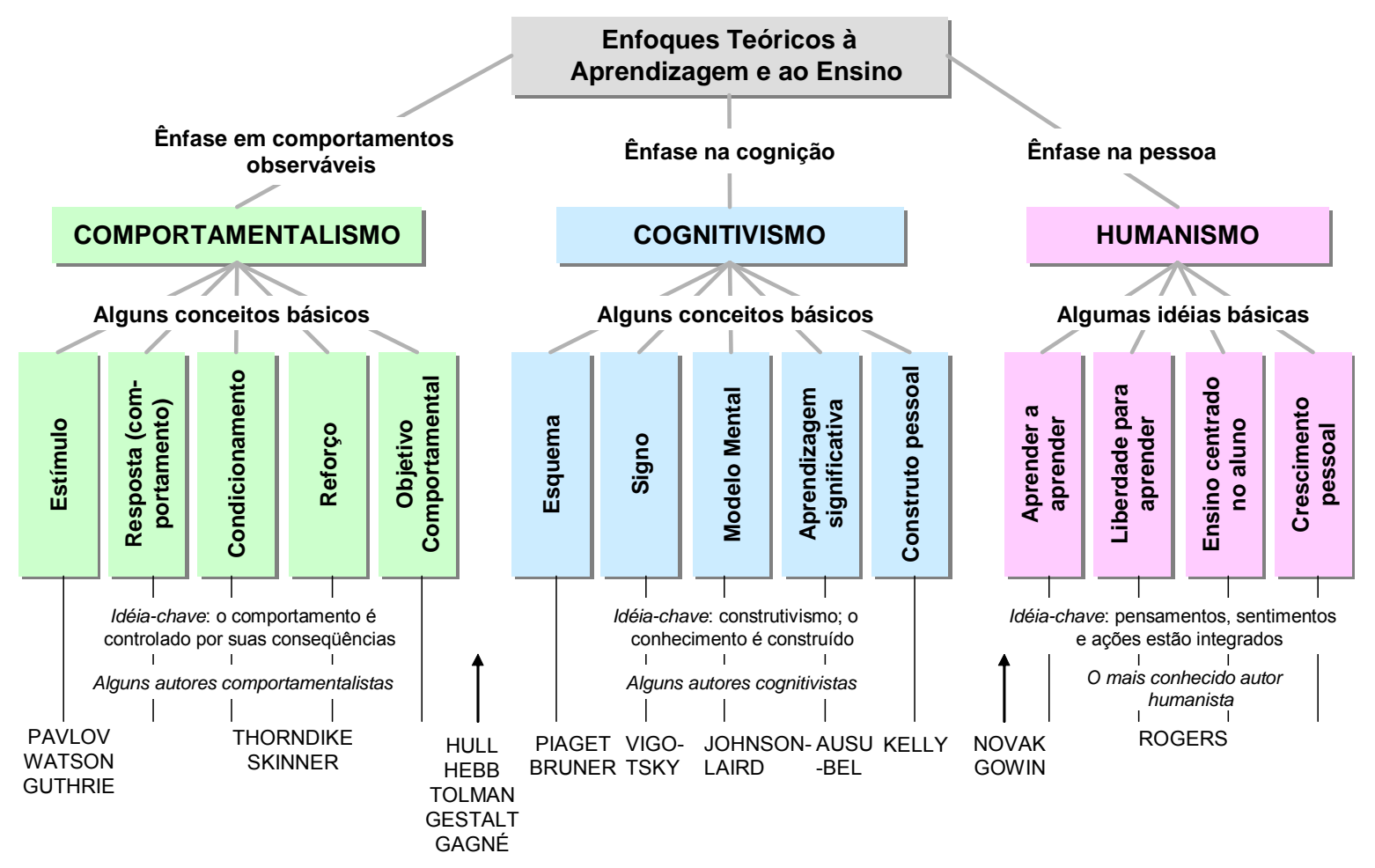

Fonte: Adaptado de MOREIRA (1999, p.18).

Dentre os enfoques apresentados, a visão behaviorista está baseada nos comportamentos observáveis e mensuráveis do sujeito, sendo a aprendizagem expressada por esses comportamentos. Relacionada a esse enfoque está a teoria conexionista, que trata "a aprendizagem como uma questão de conexões entre estímulos e respostas", supondo que “todas as respostas (comportamentos) são eliciadas por estímulos (condições que levam aos comportamentos)" (MOREIRA, 1999, p. 20). Já a teoria cognitivista trata, principalmente, de processos mentais, se ocupando da "atribuição de significados, da compreensão, transformação, armazenamento e uso da informação envolvida na cognição" (MOREIRA, 
1999, p. 15). Dentro dessa linha de pensamento, surge o construtivismo, que visualiza a cognição como um processo de construção, sendo o aluno considerado agente da construção de sua estrutura cognitiva. O enfoque humanista percebe o aluno como pessoa, considerando o domínio afetivo e os sentimentos de forma integrada ao conhecimento e comportamento (MOREIRA, 1999).

\section{As Técnicas de Ensino}

De acordo com VEIGA, "as técnicas de ensino não são naturais ao processo de ensinar, mas são condições que dão acesso a ele. Portanto, nesse sentido, elas são compreensíveis como 'artifícios', que se interpõem na relação entre o professor e o aluno, submissas à autoridade e à intencionalidade do primeiro" $(2001$, p. 8).

As técnicas de ensino podem ser agrupadas em três categorias distintas: a aula expositiva, o ensino em pequenos grupos e o ensino individualizado. Enquanto que a aula expositiva é um método mais utilizado para a transmissão de conhecimentos, o ensino em pequenos grupos (ou ensino colaborativo) e o ensino individualizado surgem como alternativas para gerar um maior nível de raciocínio, satisfação e tolerância com diferenças individuais (GODOY, 1997a; GODOY e CUNHA, 1997).

A aula expositiva consiste na exposição contínua do professor, que utiliza recursos audiovisuais e responde a perguntas eventuais dos alunos. Já o ensino em pequenos grupos, pode utilizar três técnicas diferentes (GODOY e CUNHA, 1997, p. 86-98):

- Seminário: encontro de grupo pequeno para discutir um assunto determinado;

- Método do caso: estudantes trabalham e discutem com base na descrição de uma situação real, possibilitando a análise de questões e problemas fundamentais e concretos;

- Jogo de empresa: os participantes realizam ações em uma empresa fictícia, que são implementadas em rodadas sucessivas e os resultados das decisões são acompanhados.

O ensino individualizado surge do esforço de utilização dos recursos audiovisuais e tecnológicos na educação buscando facilitar a aprendizagem através da individualização da instrução. Novas propostas, como a educação a distância e o e-learning, podem ser incluídas nessa técnica, cujas principais características são (GODOY, 1997b, p. 103):

- Respeito pelo ritmo do aluno, o importante é adquirir o domínio dos conteúdos estudados; 
- Aluno é o responsável pelo seu aprendizado, sendo exigida participação ativa;

- Objetivos são claros e subdivididos em unidades a serem aprendidas conforme uma seqüência determinada;

- Sistema de avaliação a partir de testes e/ou tarefas específicas, permitindo acompanhamento e feedback do professor.

Por fim, as várias técnicas de ensino, componentes do processo de ensino e aprendizagem, permitem diferentes intermediações entre o professor e o aluno. Algumas delas, como a exposição e a demonstração, estão mais centradas no professor; enquanto que outras, como o estudo dirigido, o estudo de texto e a pesquisa bibliográfica, estão mais centradas no aluno. As técnicas também podem estar mais centradas na individualização, como o ensino programado, ou na socialização do aluno, como o estudo do meio, seminário, debate, discussão e trabalho em grupo (ARAÚJO, 2001).

BROWN e ATKINS (1997) apresentam o nível de participação e controle do professor e do aluno para cada técnica de ensino analisada (Figura 4). Os autores ressaltam que mesmo nos extremos existe alguma participação e controle tanto do professor quanto do aluno. Além disso, o nível de participação e controle pode variar dependendo da forma como a técnica de ensino é aplicada; no caso da discussão em pequenos grupos, por exemplo, pode ser realizada uma discussão altamente estruturada e controlada pelo professor ou uma discussão livre com facilitação ocasional do professor.

\section{Figura 4 - Participação e Controle do Professor e Aluno}

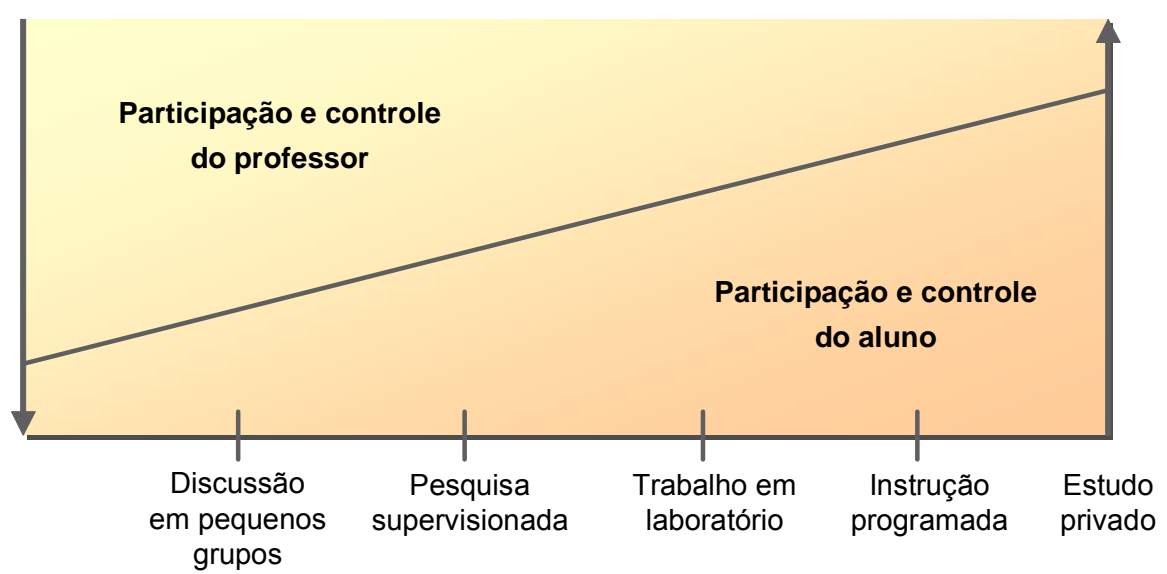

Fonte: BROWN e ATKINS (1997, p.3, tradução e cores da autora).

JOHNSON e FOA (1989, p. 69) complementam esta análise ao relacionar os níveis de interatividade cognitiva com os níveis de independência do aluno, com foco nos usos da tecnologia para o ensino (Figura 5). 
Figura 5 - Usos da tecnologia para o ensino

\section{Nível de Independência do Aluno}

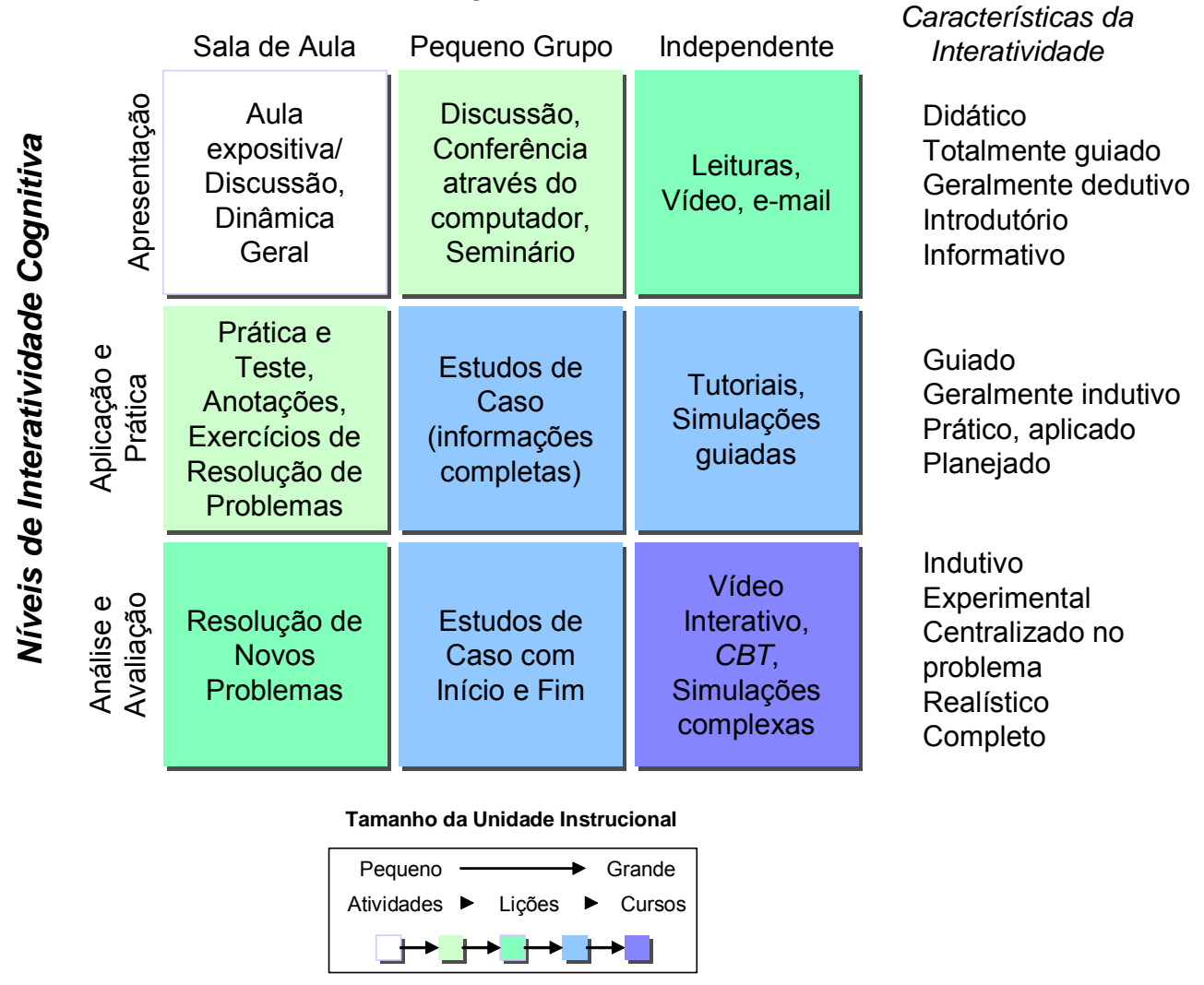

Fonte: JOHNSON e FOA (1989, p.69, tradução e cores da autora).

LIMA (2000) discute a necessidade de mudança na abordagem do processo de ensinoaprendizagem, colocando as limitações do modelo baseado no conteúdo e propondo novos caminhos:

A educação para o 'ensinar a fazer', com ênfase no conteúdo e na 'didática do ensino', onde o professor/instrutor é o transmissor do conhecimento, não consegue sobreviver ao confronto que se aproxima com uma sociedade em que as tecnologias se tornaram mais simples de ser manipuladas, porém mais difíceis de ser criadas e onde todos tenderão a desenvolver uma polivalência em suas ações, gerindo e criando novos recursos de ação sobre a realidade. [...]

Torna-se, pois, fundamental que se procurem novos caminhos e alternativas para a construção de uma educação do futuro. Alternativas que possibilitem a combinação dos diversos elementos que fizeram parte das fantasias dos educadores com visão prospectiva, tais como o respeito ao ritmo e condições de aprendizagem individual, libertação do professor das tarefas mecanicistas, possibilidades de montar programas individualizados, utilizar recursos de multimeios de forma dinâmica, desenvolver metodologias interativas [...], visando estabelecer uma relação na qual o enfoque preponderante não seja o educador/treinador, como vem sendo historicamente 
enfatizado, nem o educando/treinando isoladamente, mas sim o processo de aprendizagem em si e a interação interpessoal com tecnologias de aprendizagem que, ao envolver o educando/treinando, permitem que ele encontre o significante de cada elemento assimilado em seu quadro mental.

Com isto, o educador/treinador estará se aproximando de uma revolucionária concepção da relação ensino-aprendizagem, na qual se desenvolverá o novo paradigma a ser criado, tendo como alicerce a certeza de que o processo de aprendizagem efetiva depende muito mais do educando e de seu envolvimento e interação com o ato de aprender (necessidade) do que da boa vontade ou capacidade persuasiva (ou coercitiva) do educador/treinador e da sofisticação dos recursos de multimeio que se possa utilizar (LIMA, 2000, p. 67-69).

Nesse contexto, o aumento das discussões sobre a abordagem centrada no aluno tem levado cada vez mais educadores a reconhecer o valor de incentivar os alunos a assumirem o controle por seu próprio aprendizado (CHOU, 2001).

CHAGAS também discute a questão do controle exercido pelo professor em sala de aula:

o professor precisa de muita habilidade porque por um lado tem a responsabilidade pela organização do curso e pela disciplina da classe, mas por outro deve ouvir sugestões dos alunos sobre a metodologia e outros aspectos da aula. Espera-se que exercendo uma autonomia responsável, os alunos obtenham melhores resultados porque assim exercem um papel ativo na definição do processo de ensino/aprendizagem, que deve levar a maior motivação (2002, p. 60-61).

Corroborando com esses autores, TAPSCOTT ${ }^{6}$ afirma que o novo modelo de aprendizagem da geração $\mathrm{Net}^{7}$

deve basear-se na descoberta e na participação. Ser hipermidiático, ou seja, não linear. $\mathrm{O}$ aluno deve ser o centro do processo, ele aprende a aprender e nunca se forma. O professor pode ser denominado facilitador, que seria, segundo o autor, uma espécie de consultor e conselheiro da equipe (1999 apud CAROLEI, 2002, p. 21).

${ }^{6}$ TAPSCOTT, Don. A geração Digital. São Paulo: Ed. MAKRON, 1999.

7 “Os meios de comunicação fazem parte da nossa história [...]. Cada geração é exposta a um determinado tipo de mídia, adquire novas formas de ver o mundo e cria maneiras de expressão. [...] E a geração Net, como diz Tapscott, não assiste ao mundo, ela o experimenta, temos que pensar neles como usuários e não como expectadores" (CAROLEI, 2002, p. 110). 
Nesse novo papel, o professor

não é mais o detentor do conhecimento, aquele que sabe tudo e seus alunos são meros receptores do conhecimento. Com as milhares de informações que estão ao alcance de todos principalmente na Internet, o trabalho isolado do professor já não satisfaz mais. As mudanças de postura, a quebra de paradigmas faz com que o trabalho do professor não seja mais isolado. Com isso o trabalho em conjunto, cooperativo vem de encontro com as necessidades dos alunos na busca da construção do conhecimento e o professor entra como mediador, orientador deste conhecimento, aquele que mostra os caminhos para seus alunos em conjunto buscarem de forma interativa o saber e a construção de novos saberes (MOURA, AZEVEDO e MEHLECKE, 2002).

\section{As Teorias de Aprendizagem e o e-Learning}

Dando seqüência à discussão estabelecida neste capítulo, a seguir, serão comentadas algumas relações entre as teorias de aprendizagem e aspectos do e-learning.

De acordo com GODOY, em meados de 1950, Skinner, teórico da visão behaviorista, introduziu “a idéia das 'máquinas de ensinar' e da 'instrução programada' enquanto formas de ensino, que permitiram ao aluno aprender a partir da auto-instrução, sem necessariamente participar das situações tradicionais de sala de aula" (1997b, p. 101).

Os professores Thomas BEEBE e Peter RILEY (1997), da Southern Illinois University, identificaram alguns aspectos da instrução apoiada por computador (Computer Assisted Instruction - CAI) que se relacionam com os princípios behavioristas de estímulo resposta, entre eles estão: a resposta imediata à solicitação do aluno (estímulo), a repetição para melhorar o aprendizado e a retenção (deve ser oferecida ampla oportunidade de prática para fortalecer a ligação estímulo/resposta), a informação sobre a correção da resposta contribui para o aprendizado (feedback e reforço) e o aprendizado deve ser obtido através da condução do estudante para a resposta desejada, com cada vez menos dicas.

Simultaneamente, o aspecto cognitivo também está presente, sendo representado por (BEEBE e RILEY, 1997): informações prévias que precisam ser lembradas (orientação e lembrança) são utilizadas para o aprendizado, o aprendizado é simplificado quando processos cognitivos existentes podem ser utilizados (habilidades intelectuais) e o aprendizado é mais eficiente quando a instrução está adaptada às necessidades e características de cada estudante (individualização). 
Os modelos mais recentes de educação a distância, incluindo o e-learning, por fazer uso intenso da interação entre alunos e dos alunos com o professor, se aproximam mais da teoria cognitivista. De acordo com LEWIS (2002), a comunicação mediada por computador efetivamente sustenta a teoria construtivista, pois enfatiza o acesso a recursos e a colaboração entre alunos, estimulando a construção do próprio conhecimento. SANTOS (2002) e CHOU (2001) também mencionam a utilização da abordagem construtivista em cursos de e-learning.

Na mesma linha, GOMES comenta:

O computador, mesmo sendo considerado apenas ferramenta, oferece-nos modelos de mente e um novo meio para projetar idéias e divagações e, através de um canal valioso, a Internet, estabelecemos relações não só com o objeto do conhecimento como também com o outro, tornando possível, como na abordagem de VYGOTSKY, o fazer-se homem na intermediação com o outro (2003, p. 1).

A atuação do professor no e-learning, mencionada anteriormente, é outro aspecto que se aproxima da teoria de desenvolvimento cognitivo de VYGOTSKY, tendo em vista o "papel fundamental do professor como mediador na aquisição de significados contextualmente aceitos" e "o indispensável intercâmbio de significados entre professor e aluno" (MOREIRA, 1999, p. 120).

A abordagem humanista, proposta por ROGERS, também pode ser relacionada com o e-learning, tendo em vista as questões já discutidas do aluno no centro do processo de aprendizagem e do professor como facilitador. De acordo com MOREIRA, a abordagem proposta por ROGERS

implica que o ensino seja centrado no aluno, que a atmosfera da sala de aula tenha o estudante como centro. Implica confiar na potencialidade do aluno para aprender, em criar condições favoráveis para o crescimento e auto-realização do aluno, em deixá-lo livre para aprender, manifestar seus sentimentos, escolher suas direções, formular seus próprios problemas, decidir sobre seu próprio curso de ação, viver as conseqüências de suas escolhas. O professor passa a ser um facilitador, cuja autenticidade e capacidade de aceitar o aluno como pessoa e de colocar-se no lugar do aluno são mais relevantes, para criar condições para que o aluno aprenda, do que sua erudição, suas habilidades e o uso que faz de recursos instrucionais (1999, p. 147).

Tendo em vista a mudança radical proposta na abordagem de ROGERS, MOREIRA (1999) comenta que é preciso analisar até onde é possível utilizar os princípios de 
aprendizagem propostos sem desconforto para professores e estudante, visando a facilitar a aprendizagem significante.

Considerando as diferentes técnicas e tecnologias que podem ser utilizadas no $e$ learning, esse método de ensino não pode ser relacionado com uma única teoria de aprendizagem. Além disso, é possível realizar através da Internet determinadas atividades que normalmente são presenciais, como o jogo de empresas e o estudo de caso, ampliando ainda mais esse leque. De qualquer forma, os modelos mais recentes de e-learning, enfatizando o aluno no centro do processo e a importância da interação e da construção colaborativa, parecem estar mais próximos do enfoque cognitivista e humanista. Apesar disso, nada impede que seus recursos também sejam utilizados para medir comportamentos, em um modelo mais behaviorista. A discussão mais detalhada sobre essas atividades e recursos está apresentada no capítulo de revisão bibliográfica sobre e-learning.

\subsubsection{O Estilo de Aprendizagem}

De acordo com KOLB, “o processo de aprendizagem não é idêntico para todos os seres humanos. Parece que as estruturas psicológicas que regem o aprendizado permitem emergir processos individuais adaptativos únicos, que tendem a enfatizar algumas orientações adaptativas" (1984, p. 62, tradução da autora).

Considerando "que o processo de aprendizagem é dirigido pelas necessidades e objetivos individuais, os estilos de aprendizagem tornam-se altamente individuais tanto na direção quanto no processo" (KOLB, RUBIN e McINTYRE, 1978, p. 39). Além disso, as experiências particulares e as demandas atuais do ambiente podem influir no desenvolvimento de determinadas habilidades de aprendizagem (WILSON, 2000).

De acordo com CARDOSO e JANDL, "o conceito de estilo de aprendizagem é representado, simultaneamente, por três componentes: (1) trata-se do modo com que se processa a informação; (2) consiste em uma seleção dinâmica de estratégias de aprendizagem e (3) compromete a própria percepção do aluno com respeito a sua aprendizagem" (1998, p. 137).

BONHAM apresenta um conceito de estilo de aprendizagem, que, segundo o autor, está em concordância com aquele utilizado pelos educadores em geral: "a forma característica em que o aprendiz opera em uma situação de aprendizagem" (1989, p. 29, tradução da autora). 
Estilo de aprendizagem também pode ser conceituado como "a forma típica de uma pessoa se comportar, sentir e processar informação em situações de aprendizagem" (STEPHEN, 1987, p. 41, tradução da autora).

A identificação dos estilos de aprendizagem predominantes nos alunos permite ao professor utilizar estratégias de ensino que se aproximem das preferências dos alunos e, ao mesmo tempo, favoreçam e incentivem o desenvolvimento de outros estilos, aumentando a capacidade de adaptabilidade e flexibilidade (CARDOSO e JANDL, 1998; BONHAM, 1989).

BONHAM (1989:29) ressalta que existem diferentes idéias sobre o que é um estilo e como essa informação deve ser utilizada. O Quadro 3, a seguir, apresenta um resumo das principais teorias de estilo de aprendizagem, relacionando: autor, teoria, instrumento, estilos, escala utilizada no instrumento e sujeitos participantes das pesquisas. 
Quadro 3 - Teorias e Instrumentos de Estilo de Aprendizagem

\begin{tabular}{|c|c|c|c|c|c|c|c|}
\hline TEORIA & $\begin{array}{l}\text { Diferenciação } \\
\text { psicológica }\end{array}$ & $\begin{array}{l}\text { Estilo cognitivo } \\
\text { educacional }\end{array}$ & $\begin{array}{l}\text { (Relacionado a) } \\
\text { Aprendizado } \\
\text { Vivencial }\end{array}$ & $\begin{array}{l}\text { Tipos } \\
\text { psicológicos } \\
\text { (Jung) }\end{array}$ & $\begin{array}{l}\text { (Relacionado ao } \\
\text { aprendizado } \\
\text { universitário em } \\
\text { sala de aula) }\end{array}$ & $\begin{array}{l}\text { (Relacionado ao } \\
\text { aprendizado de } \\
\text { crianças em sala } \\
\text { de aula) }\end{array}$ & Não identificado \\
\hline INSTRUMENTO & $\begin{array}{l}\text { Teste Figuras } \\
\text { Encaixadas } \\
\text { Teste de Grupos de } \\
\text { Figuras Encaixadas }\end{array}$ & $\begin{array}{l}\text { Inventário de } \\
\text { Estilo de } \\
\text { Interesse } \\
\text { Cognitivo }\end{array}$ & $\begin{array}{l}\text { Inventário de } \\
\text { Estilo de } \\
\text { Aprendizagem }\end{array}$ & $\begin{array}{l}\text { Indicador de Tipo } \\
\text { Myers-Briggs }\end{array}$ & $\begin{array}{l}\text { Escala de Estilos } \\
\text { de Aprendizagem } \\
\text { do Estudante } \\
\text { Grasha- } \\
\text { Riechmann }\end{array}$ & $\begin{array}{l}\text { Pesquisa de } \\
\text { Preferências de } \\
\text { Produtividade } \\
\text { Ambiental }\end{array}$ & $\begin{array}{l}\text { Inventário de } \\
\text { Estilos de } \\
\text { Aprendizagem }\end{array}$ \\
\hline $\begin{array}{l}\text { ELEMENTOS DO } \\
\text { ESTILO }\end{array}$ & $\begin{array}{l}\text { Independência, } \\
\text { dependência (field) }\end{array}$ & $\begin{array}{l}\text { Símbolos e seus } \\
\text { significados ( } 22 \\
\text { elementos), } \\
\text { determinantes } \\
\text { culturais (3), } \\
\text { modalidades de } \\
\text { inferência (5) }\end{array}$ & $\begin{array}{l}\text { Acomodador, } \\
\text { Divergente, } \\
\text { Assimilador, } \\
\text { Convergente }\end{array}$ & $\begin{array}{l}\text { Extroversão/ } \\
\text { Introversão, } \\
\text { Sensação/ } \\
\text { Intuição, } \\
\text { Pensamento/ } \\
\text { Sentimento, } \\
\text { Percepção/ } \\
\text { Julgamento }\end{array}$ & $\begin{array}{l}\text { Independente/ } \\
\text { Dependente, } \\
\text { Colaborativo/ } \\
\text { Competitivo, } \\
\text { Participante/ } \\
\text { Ausente }\end{array}$ & $\begin{array}{l}\text { Ambiente } \\
\text { imediato (4 } \\
\text { elementos), } \\
\text { Emocional (4), } \\
\text { Necessidades } \\
\text { sociais (4), } \\
\text { Necessidades } \\
\text { físicas (9) }\end{array}$ & $\begin{array}{l}\text { Condições (4 } \\
\text { elementos, cada } \\
\text { um com } 2 \\
\text { opções), } \\
\text { Conteúdo (4), } \\
\text { forma (4), } \\
\text { expectativa }\end{array}$ \\
\hline TIPO & $\begin{array}{l}\text { Formas geométricas } \\
\text { para serem } \\
\text { combinadas }\end{array}$ & $\begin{array}{l}\text { Escala do tipo } \\
\text { Likert }\end{array}$ & $\begin{array}{l}\text { Ordenação de } \\
\text { alternativas }\end{array}$ & Escolha forçada & $\begin{array}{l}\text { Escala do tipo } \\
\text { Likert }\end{array}$ & $\begin{array}{l}\text { Escala do tipo } \\
\text { Likert }\end{array}$ & $\begin{array}{l}\text { Ordenação de } \\
\text { alternativas }\end{array}$ \\
\hline $\begin{array}{l}\text { SUJEITOS PARA } \\
\text { NORMALIZAÇÃO }\end{array}$ & $\begin{array}{l}\text { Ampla variedade de } \\
\text { adultos e crianças }\end{array}$ & $\begin{array}{l}\text { Estudantes de } \\
\text { graduação }\end{array}$ & $\begin{array}{l}\text { Gerentes de } \\
\text { empresas, grupos } \\
\text { ocupacionais, } \\
\text { estudantes } \\
\text { formados e de } \\
\text { graduação }\end{array}$ & $\begin{array}{l}\text { Ampla variedade } \\
\text { de adultos e } \\
\text { crianças }\end{array}$ & $\begin{array}{l}\text { Desconhecido: } \\
\text { assumir } \\
\text { estudantes de } \\
\text { graduação }\end{array}$ & $\begin{array}{l}\text { Adultos (não } \\
\text { descrito) }\end{array}$ & Não declarado \\
\hline REFERÊNCIA & $\begin{array}{l}\text { Witkin, Moore, } \\
\text { Goodenogh e Cox, } \\
1977\end{array}$ & Nunney, 1978 & Kolb, 1976 & $\begin{array}{l}\text { Myers and } \\
\text { McCaulley, } 1985\end{array}$ & Grasha, 1972 & $\begin{array}{l}\text { Price, Dunn and } \\
\text { Dunn, } 1982\end{array}$ & Canfield, 1983 \\
\hline
\end{tabular}

Fonte: BONHAM (1989. p. 30, tradução da autora). 
A partir da análise realizada por BONHAM (1989), foi possível complementar as teorias de estilos de aprendizagem com outras teorias apresentadas por outros autores (STEPHEN, 1987; WILSON, 2000; MUMFORD e HONEY, 1992; VINCENT e ROSS, 2001; BARBOSA, 2002; FELDER, 1993; MONTGOMERY, 1995). Dessa forma, o Quadro 4 apresenta um resumo de todas as teorias identificadas nesta pesquisa bibliográfica.

Quadro 4 - Resumo das Teorias e Instrumentos de Estilos de Aprendizagem

\begin{tabular}{|c|c|c|c|}
\hline REFERÊNCIA & TEORIA & INSTRUMENTO & $\begin{array}{c}\text { ELEMENTOS DOS } \\
\text { ESTILOS }\end{array}$ \\
\hline GRASHA, 1972 & $\begin{array}{l}\text { (Relacionado ao } \\
\text { aprendizado } \\
\text { universitário em } \\
\text { sala de aula) }\end{array}$ & $\begin{array}{l}\text { Escala de Estilos de } \\
\text { Aprendizagem do } \\
\text { Estudante Grasha- } \\
\text { Riechmann } \\
\end{array}$ & $\begin{array}{l}\text { Independente/ Dependente, } \\
\text { Colaborativo/ Competitivo, } \\
\text { Participante/ Ausente }\end{array}$ \\
\hline KOLB, 1976 & $\begin{array}{l}\text { (Relacionado a) } \\
\text { Aprendizagem } \\
\text { Vivencial } \\
\end{array}$ & $\begin{array}{l}\text { Inventário de Estilo } \\
\text { de Aprendizagem }\end{array}$ & $\begin{array}{l}\text { Acomodador, Convergente, } \\
\text { Assimilador, Divergente }\end{array}$ \\
\hline \begin{tabular}{|l|} 
WITKIN, \\
MOORE, \\
GOODENOGH e \\
COX, 1977 \\
\end{tabular} & $\begin{array}{l}\text { Diferenciação } \\
\text { psicológica }\end{array}$ & $\begin{array}{l}\text { Teste Figuras } \\
\text { Encaixadas }\end{array}$ & $\begin{array}{l}\text { Independência, dependência } \\
\text { (campo) }\end{array}$ \\
\hline NUNNEY, 1978 & $\begin{array}{l}\text { Estilo cognitivo } \\
\text { educacional }\end{array}$ & $\begin{array}{l}\text { Inventário de Estilo } \\
\text { de Interesse } \\
\text { Cognitivo }\end{array}$ & $\begin{array}{l}\text { Símbolos e seus significados } \\
\text { ( } 22 \text { elementos), determinantes } \\
\text { culturais (3), modalidades de } \\
\text { inferência (5) }\end{array}$ \\
\hline $\begin{array}{l}\text { ALBRECHT, } \\
1980\end{array}$ & $\begin{array}{l}\text { Compreensão } \\
\text { sobre cérebro }\end{array}$ & Mindex & $\begin{array}{l}\text { Blue sky; Blue earth; Red sky; } \\
\text { Red earth }\end{array}$ \\
\hline $\begin{array}{l}\text { LYNCH, 1981/ } \\
1984\end{array}$ & $\begin{array}{l}\text { Estrutura do } \\
\text { cérebro }\end{array}$ & BrainMap & $\begin{array}{l}\text { Controle; Exploração; Compra; } \\
\text { Preservação }\end{array}$ \\
\hline $\begin{array}{l}\text { HERMANN } \\
1981 / 1988\end{array}$ & $\begin{array}{l}\text { Funcionamento } \\
\text { do cérebro }\end{array}$ & $\begin{array}{l}\text { Formulário de } \\
\text { Participante } \\
\text { Pesquisa Hermann } \\
\end{array}$ & $\begin{array}{l}\text { Cerebral left; Limbic left; } \\
\text { Cerebral right; Limbic right }\end{array}$ \\
\hline $\begin{array}{l}\text { PRICE, DUNN e } \\
\text { DUNN, } 1982\end{array}$ & $\begin{array}{l}\text { (Relacionado ao } \\
\text { aprendizado de } \\
\text { crianças em sala } \\
\text { de aula) }\end{array}$ & $\begin{array}{l}\text { Pesquisa de } \\
\text { Preferências de } \\
\text { Produtividade } \\
\text { Ambiental }\end{array}$ & $\begin{array}{l}\text { Ambiente imediato (4 } \\
\text { elementos), Emocional (4), } \\
\text { Necessidades sociais (4), } \\
\text { Necessidades físicas (9) }\end{array}$ \\
\hline $\begin{array}{l}\text { HONEY e } \\
\text { MUMFORD, } \\
1982\end{array}$ & $\begin{array}{l}\text { (Relacionado a) } \\
\text { Aprendizagem } \\
\text { Vivencial }\end{array}$ & $\begin{array}{l}\text { Questionário de } \\
\text { Estilos de } \\
\text { Aprendizagem }\end{array}$ & $\begin{array}{l}\text { Executores/Ativista; } \\
\text { Executores/Pragmático; } \\
\text { Pensadores/Refletor; } \\
\text { Pensadores/Teorista } \\
\end{array}$ \\
\hline $\begin{array}{l}\text { CANFIELD, } \\
1983\end{array}$ & Não identificado & $\begin{array}{l}\text { Inventário de Estilos } \\
\text { de Aprendizagem }\end{array}$ & $\begin{array}{l}\text { Condições (4 elementos, cada } \\
\text { um com } 2 \text { opções), Conteúdo } \\
\text { (4), forma (4), expectativa }\end{array}$ \\
\hline
\end{tabular}


Quadro 4 - Resumo das Teorias e Instrumentos de Estilos de Aprendizagem (continuação)

\begin{tabular}{|l|l|l|l|}
\hline \multicolumn{1}{|c|}{ REFERÊNCIA } & \multicolumn{1}{|c|}{ TEORIA } & INSTRUMENTO & \multicolumn{1}{|c|}{$\begin{array}{c}\text { ELEMENTOS DOS } \\
\text { ESTILOS }\end{array}$} \\
\hline WARD, 1983 & Não disponível & Não disponível & $\begin{array}{l}\text { Idealista; Pragmático; } \\
\text { Realista; Existencialista }\end{array}$ \\
\hline $\begin{array}{l}\text { MYERS e } \\
\text { MCCAULLEY, }\end{array} 985$ & $\begin{array}{l}\text { Tipos psicológicos } \\
\text { (Jung) }\end{array}$ & $\begin{array}{l}\text { Indicador de Tipo } \\
\text { Myers-Briggs }\end{array}$ & $\begin{array}{l}\text { Extroversão/ Introversão, } \\
\text { Sensação/ Intuição, } \\
\text { Pensamento/ Sentimento, } \\
\text { Percepção/ Julgamento }\end{array}$ \\
\hline KANNAR, 1995 & Fatores fisiológicos & $\begin{array}{l}\text { Teste de Estilos de } \\
\text { Aprendizagem }\end{array}$ & $\begin{array}{l}\text { Auditivo; Visual; } \\
\text { Cinestésico }\end{array}$ \\
\hline $\begin{array}{l}\text { CASADO, } \\
1998\end{array}$ & $\begin{array}{l}\text { Tipos psicológicos } \\
\text { (Jung) }\end{array}$ & $\begin{array}{l}\text { Inventário } \\
\text { Brasileiro para } \\
\text { Diagnóstico das } \\
\text { Diferenças } \\
\text { Individuais }\end{array}$ & $\begin{array}{l}\text { Extroversão/ Introversão, } \\
\text { Sensação/ Intuição, } \\
\text { Pensamento/ Sentimento, } \\
\text { Percepção/ Julgamento }\end{array}$ \\
\hline $\begin{array}{l}\text { FELDER e } \\
\text { SALOMAN, 1998 }\end{array}$ & $\begin{array}{l}\text { Indice de Estilos de } \\
\text { Aprendizagem }\end{array}$ & $\begin{array}{l}\text { Apresentação (visual x } \\
\text { verbal); Percepção } \\
\text { (sensorial x intuitivo); } \\
\text { Organização (indutiva x } \\
\text { dedutiva); Processamento } \\
\text { (ativo x reflexivo); } \\
\text { Compreensão (seqüencial } \\
\text { x global) }\end{array}$ \\
\hline
\end{tabular}

Organizado por JACOBSOHN, L. V.

Buscando organizar as diferentes abordagens sobre o tema, CLAXTON e MURRELL (1988) propõem uma classificação em quatro categorias, sendo cada uma baseada em níveis mais "profundos" das características humanas (Figura 6).

Figura 6 - Categorias para Agrupar as Teorias de Estilo de Aprendizagem

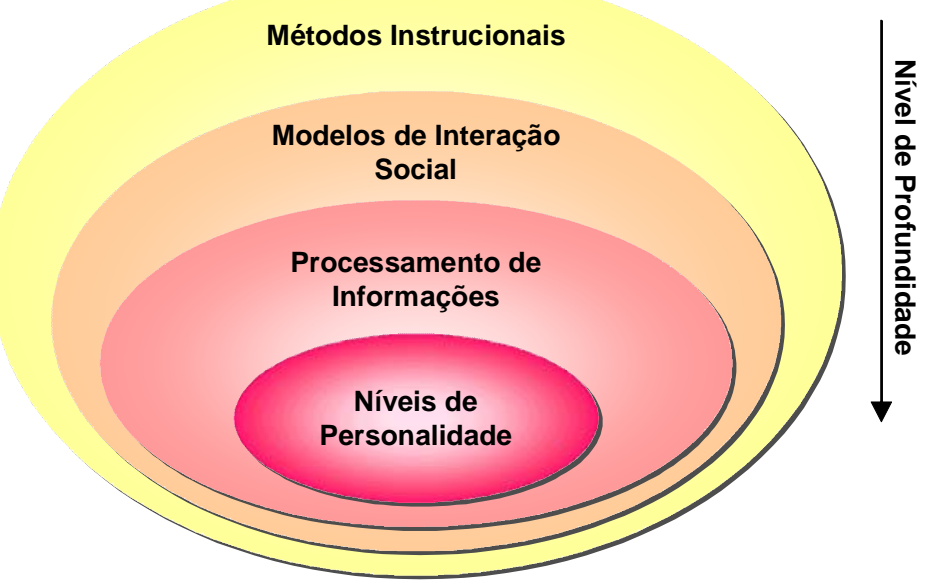

Fonte: Adaptado de CLAXTON e MURRELL (1988). 
Analisando os aspectos em comum das teorias apresentadas no Quadro 4 é possível sugerir algumas relações com as categorias propostas por CLAXTON e MURRELL (1988) na Figura 6.

A primeira categoria, Métodos Instrucionais, está relacionada ao ambiente preferido para aprendizagem, onde a teoria proposta por PRICE, DUNN e DUNN (1982) pode ser considerada (GRIGGS, 1991).

A teoria proposta por GRASHA (1972) pode ser classificada na categoria Modelos de Interação Social, considerando que trata da forma com que o indivíduo interage na sala de aula, descrevendo os diferentes papéis assumidos pelos alunos na interação com os colegas, professores e conteúdo do curso (GRIGGS, 1991; HEINEMAN, 1995).

As teorias que envolvem a abordagem intelectual preferida para assimilar informações são as que podem ser classificadas na categoria Processamento de Informações. Dentre elas é possível citar as que tratam do funcionamento e estrutura do cérebro (HERMANN, 1981; LYNCH, 1981; ALBRECHT, 1980) e outras com foco na complexidade cognitiva (KOLB, 1976; HONEY e MUMFORD, 1982; KANNAR, 1995; FELDER e SALOMAN, 1998).

Os modelos que abordam a personalidade do indivíduo podem ser classificados na categoria Níveis de Personalidade, dentre eles é possível citar a proposta de WITKIN (1977), baseado na teoria de diferenciação psicológica, e aqueles baseados na teoria de Tipos Psicológicos de Jung (MYERS e McCAULLEY, 1985; CASADO, 1998), conforme sugerido por GRIGGS (1991).

Considerando a profundidade da teoria de Tipos Psicológicos e a validade comprovada do Inventário Brasileiro para Diagnóstico das Diferenças Individuais, proposto por CASADO (1998), este foi selecionado para analisar o estilo de aprendizagem dos alunos desta pesquisa. Os critérios considerados nessa escolha e uma breve descrição do instrumento são apresentados no capítulo de metodologia da pesquisa. A seguir, estão resumidos alguns aspectos da teoria de Tipos Psicológicos, com foco no processo de aprendizagem. 


\section{Os Tipos Psicológicos de Jung}

O conceito de tipo, segundo a concepção de Jung, se refere ao: "exemplo característico de uma disposição geral que se observa nos indivíduos” (CASADO, 1993, p. 31).

“Jung apresentou inicialmente seus dois tipos básicos, gerais, de comportamento ou de atitude, que se distinguem pela direção que dão a seus interesses e ao movimento da libido" (CASADO, 1993, p. 31); ou seja, pela relação do indivíduo com o objeto9? a Introversão e a Extroversão. Assim, “o extrovertido é o sujeito que busca no ambiente a energia e o objetivo para agir; [...] adora encontrar pessoas, conversar sobre tudo e possui enorme facilidade em estabelecer contatos", enquanto que o "tipo introvertido ocupa-se dos seus processos internos suscitados pelos fatos externos, [...] é mais reservado, se relaciona com poucas pessoas e se satisfaz com atividades solitárias" (CASADO, 1994, p. 2).

De acordo com CASADO, “as disposições básicas elucidaram parte das questões colocadas por Jung acerca das diferenças individuais, mas restavam muitas indagações sobre determinadas tendências no processo de ajustamento do homem" (1998, p. 42). Dessa forma, as funções psicológicas, atividades psíquicas que orientam o homem nas suas interações com o meio ambiente e nos seus processos internos, também deveriam ser consideradas para a compreensão das diferenças individuais.

Considerando os dois momentos que fazem parte da ação humana, a captação de informações sobre as situações e a decisão necessária para ação, Jung denominou as funções psicológicas voltadas à informação de Funções Perceptivas e as funções voltadas ao processo de decisão de Funções Judicativas (CASADO, 1998).

As duas funções perceptivas são a Sensação e a Intuição. "A pessoa do tipo sensação percebe os fatos através dos órgãos dos sentidos; é [...] mais voltada ao que é real e concreto [...] capta primordialmente detalhes e a importância do que é material. Seu oposto, o tipo intuição, está mais propenso a buscar novas possibilidades e desafios que possam existir no futuro" (CASADO, 1994, p. 2).

\footnotetext{
8 "[...] para Jung o conceito de libido equivale a energia psíquica, ou seja, intensidade do processo psíquico" (CASADO, 1998, p. 35).

9 "Por objeto entende-se tudo o que estiver fora da individualidade do homem, tudo o que representar qualquer realidade distinta do sujeito" (CASADO, 1998, p. 35).
} 
Já as funções judicativas, responsáveis por avaliar o que é percebido pelo indivíduo, constituem dos tipos Pensamento e Sentimento. Enquanto que o tipo Pensamento toma decisões baseadas em aspectos objetivos, racionais, lógicos e critérios pessoais, o tipo Sentimento segue a lógica do coração, considerando aspectos emocionais resultantes da decisão e os valores das pessoas envolvidas (CASADO, 1994, p. 3).

Por fim, a postura do indivíduo frente ao mundo define as funções Julgamento e Percepção, considerando se o indivíduo está mais propenso a decidir ou se está mais voltado à captação de informações, respectivamente.

A pessoa do tipo percepção possui maior flexibilidade e se adapta a situações de
mudança. Este tipo de pessoa necessita de muita informação antes de tomar uma
decisão. Já as pessoas do tipo julgamento preferem ter as coisas estabelecidas e
acabadas, por isso tendem a tomar rapidamente suas decisões; além disso, gostam de
ter um plano para seguir e metas a alcançar (CASADO, 1994, p. 3).

Essa breve análise deixa claro que cada um dos tipos psicológicos possui aspectos positivos e negativos. Assim, a compreensão do tipo psicológico pelo indivíduo possibilita que gerencie seu potencial e suas limitações (CASADO, 1994).

O Quadro 5 resume as implicações das preferências individuais em relação ao processo de aprendizagem para cada tipo psicológico, propostas por BOOTH e WINZAR (1993), incluindo também as características mencionadas por CASADO (1998). As letras que se encontram entre parêntesis logo após cada tipo psicológico se referem à nomenclatura adotada internacionalmente, utilizada para facilitar o registro e a comparação dos dados (CASADO, 1998, p. 103).

É importante ressaltar que "estas formulações são válidas para condições normais. Sempre que condições perturbadoras estiverem em curso há o risco de desenvolvimento de um pseudotipo, mascarando a disposição natural do indivíduo e falsificando outra disposição contrária. Este processo não é salutar podendo levar o indivíduo à neurose, sendo que a saúde só será restabelecida se a disposição original for restaurada” (CASADO, 1998, p. 36). 
Quadro 5 - Preferências de Aprendizado, por Tipo Psicológico

\begin{tabular}{|c|c|}
\hline $\begin{array}{l}\text { Introversão (I) } \\
\text { Idéias, relacionamentos } \\
\text { Pensamento, profunda concentração } \\
\text { Regras em primeiro lugar } \\
\text { Leitura, raciocínio verbal } \\
\text { Satisfação com trabalho solitário } \\
\text { Conceitos } \\
\text { Testes escritos }\end{array}$ & $\begin{array}{l}\text { Extroversão (E) } \\
\text { Fatos específicos } \\
\text { Ação espontânea } \\
\text { Exemplos em primeiro lugar } \\
\text { Conversa, discussão, com um grupo } \\
\text { Gosta de ter pessoas ao redor } \\
\text { Aplicação prática } \\
\text { Testes orais } \\
\text { Atividade psicomotora }\end{array}$ \\
\hline $\begin{array}{l}\text { Sensação (S) } \\
\text { Real, concreto, tangível } \\
\text { Sem complicação } \\
\text { Tarefas que envolvem cuidado, } \\
\text { perfeição } \\
\text { Progresso passo a passo } \\
\text { Observação de detalhes } \\
\text { Regras-exemplo com muitas variações } \\
\text { Memória de fatos, detalhes } \\
\text { Interesses práticos } \\
\text { Desempenho, inteligência motor } \\
\text { espacial } \\
\text { Testes de escolhas objetivas } \\
\text { Aplicação do que aprendeu }\end{array}$ & $\begin{array}{l}\text { Intuição (N) } \\
\text { Significados, palavras, símbolos, abstrações } \\
\text { Complexo } \\
\text { Tarefas que envolvem rápidos insights e } \\
\text { percepção de relacionamentos } \\
\text { Encontrando o próprio caminho no novo } \\
\text { material, descoberta } \\
\text { Lampejos de insights } \\
\text { Exemplos suficientes para ter um princípio } \\
\text { Compreensão de conceitos gerais } \\
\text { Imaginação, possibilidades } \\
\text { Interesses intelectuais (independente da } \\
\text { capacidade e inteligência) } \\
\text { Leitura } \\
\text { Testes com tempo determinado, analítico, } \\
\text { teórico } \\
\text { Aprendizado de novos modelos }\end{array}$ \\
\hline $\begin{array}{l}\text { Pensamento (T) } \\
\text { Objetivo } \\
\text { Lógico, organização sistemática } \\
\text { Justiça } \\
\text { Cético, crítico } \\
\text { Matemática, ciência, habilidade técnica }\end{array}$ & $\begin{array}{l}\text { Subjetivo } \\
\text { Valor, mérito } \\
\text { Aprendizado através de relações interpessoais } \\
\text { Elogios } \\
\text { Harmonia, amizade } \\
\text { Consciência social }\end{array}$ \\
\hline $\begin{array}{l}\text { Julgamento (J) } \\
\text { Decisivo } \\
\text { Trabalha de forma estável e ordenada } \\
\text { Instrução formalizada, estrutura } \\
\text { Decisões muito rápidas } \\
\text { Tarefas pré-determinadas } \\
\text { Direcionado para a conclusão }\end{array}$ & $\begin{array}{l}\text { Purioso } \\
\text { Trabalha de forma flexível, segue impulsos } \\
\text { Resolução informal de problemas } \\
\text { Decisões só com muita informação } \\
\text { Tarefas descobertas } \\
\text { Gerenciamento de problemas emergentes } \\
\text { Ações improvisadas, adaptação a situações de } \\
\text { mudança } \\
\text { Segue o fluxo } \\
\text { Ainda aberto para mais informações }\end{array}$ \\
\hline
\end{tabular}

Fonte: Adaptado de BOOTH e WINZAR (1993, p. 109-120, tradução da autora). 


\subsubsection{A Aprendizagem e as Competências}

De acordo com LOPES, "a questão fundamental é como prover as competências de gestão necessárias ao exercício profissional do administrador, nesse contexto de relações sistêmicas complexas, incertezas e descontinuidades" (P.C. LOPES, 2002, p. 1).

Philippe PERRENOUD, professor da Université de Genéve, afirma que a competência "não se forma com a assimilação de conhecimentos suplementares, gerais ou locais, mas sim com construção de um conjunto de disposições e esquemas que permitem mobilizar os conhecimentos na situação, no momento certo e com discernimento" (1999, p. 31).

De acordo com PERRENOUD, para o desenvolvimento de competências, não é preciso abrir mão do conteúdo, visto que "quanto mais complexas, abstratas, mediatizadas por tecnologias, apoiadas em modelos sistêmicos da realidade forem consideradas as ações, mais conhecimentos aprofundados, avançados, organizados e confiáveis elas exigem” $(1999$, p. 7).

Dessa forma, "um estudante será levado a construir competências de alto nível somente confrontando-se, regular e intensamente, com problemas numerosos, complexos e realistas, que mobilizem diversos tipos de recursos cognitivos" (PERRENOUD, 1999, p. 57).

RHINESMITH propõe um ciclo de aprendizagem das competências globais do gestor, conforme apresentado na Figura 7. De acordo com o autor, “[...] as competências desenvolvem-se pelo fluxo constante do quadro mental ${ }^{10}$ para a prática, desta para a tarefa e da tarefa para o quadro mental de novo. Ao aplicar o quadro mental ao comportamento, o gestor global está a desenvolver uma competência”. O autor ressalta que o quadro mental não é uma competência, visto que esta "só se desenvolve quando os quadros mentais se traduzem em comportamentos aplicados" (1993, p. 75).

De igual modo, uma característica não é uma competência. Uma pessoa pode ser flexível, mas não aplicar essa flexibilidade no trabalho com a mudança organizacional. A flexibilidade transforma-se numa competência de um gestor global quando este a usa para se adaptar às mudanças da organização [...] (RHINESMITH, 1993, p.75).

Assim, as características são consideradas como um fator contribuinte do quadro mental, estando representadas deste modo no modelo da Figura 7.

\footnotetext{
${ }^{10}$ Quadro mental: forma de pensar e de perceber o mundo (RHINESMITH, 1993).
} 


\section{Figura 7 - Ciclo de Aprendizagem das Competências Globais}

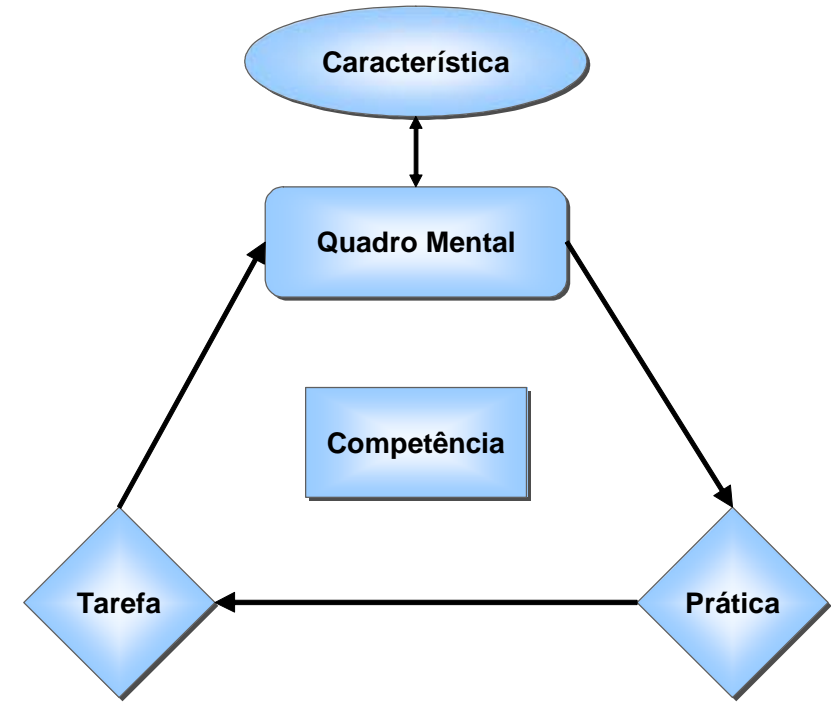

Fonte: RHINESMITH (1993, p. 75).

O ciclo de aprendizado proposto por RHINESMITH (1993) e o conceito de competência de FLERUY e FLEURY (2001), apresentado anteriormente na Figura 2, estão coerentes com o trabalho de ZARIFIAN ${ }^{11}$ (1994 apud FLEURY e FLEURY, 2001); ou seja, o ser e o fazer não se separam. Dessa forma, a competência se refere a como o conhecimento se articula com as características pessoais, valores, visão de mundo e o contexto de trabalho, sendo que os componentes afetivo e atitudinal são importantes no desenvolvimento de competências. Portanto, a inadequação dos sistemas de ensino se deve ao foco em um modelo de transmissão de conhecimentos e atitudes, ao invés do incentivo ao espírito crítico do aluno, ensinando-o a aprender (LUZ, 1998).

BOK corrobora, quando afirma que "em termos de pedagogia, a preparação para a aprendizagem contínua implica a mudança para formas mais ativas de instrução" (1988, p. 192).

Outra abordagem para o desenvolvimento de competências é apresentada por LE BOTERF ${ }^{12}$ (Quadro 6), em que o autor propõe uma "conjugação de situações de aprendizagem que podem propiciar a transformação do conhecimento em competência", agregando valor ao indivíduo e à organização (1994 apud FLEURY e FLEURY, 2001, p. 29).

${ }^{11}$ ZARIFIAN, P. Compétences et organization qualifiante em milieu industriel. In: MINET, Francis, PARLIER, Michel, WITTE, Serge. La Competénce: mythe, construction ou realité? Paris: Liaisons, 1994.

${ }^{12}$ LE BOTERF, G. De la compétence. Paris: Les Edtions d’ Organization, 1994. 
Quadro 6 - Processo de Desenvolvimento de Competências

\begin{tabular}{|l|l|l|}
\hline \multicolumn{1}{|c|}{ TIPO } & \multicolumn{1}{|c|}{ FUNÇÃO } & COMO DESENVOLVER \\
\hline Conhecimento teórico & Entendimento, interpretação & $\begin{array}{l}\text { Educação formal e } \\
\text { continuada }\end{array}$ \\
\hline $\begin{array}{l}\text { Conhecimento sobre os } \\
\text { procedimentos }\end{array}$ & Saber como proceder & $\begin{array}{l}\text { Educação formal e } \\
\text { experiência profissional }\end{array}$ \\
\hline Conhecimento empírico & Saber como fazer & Experiência profissional \\
\hline Conhecimento social & Saber como se comportar & $\begin{array}{l}\text { Experiência social e } \\
\text { profissional }\end{array}$ \\
\hline Conhecimento cognitivo & $\begin{array}{l}\text { Saber como lidar com a } \\
\text { informação, saber como } \\
\text { aprender }\end{array}$ & $\begin{array}{l}\text { Educação formal e } \\
\text { continuada, e experiência } \\
\text { social e profissional }\end{array}$ \\
\hline
\end{tabular}

Fonte: FLEURY e FLEURY (2001, p. 28).

PERRENOUD cita a necessidade de o professor estabelecer um novo contrato didático com o aluno para a formação de competências:

\begin{abstract}
Em uma pedagogia centrada nos conhecimentos, o contrato do aluno é escutar, tentar entender, fazer os exercícios com aplicação e restituir suas aquisições por intermédio do referencial de testes de conhecimento papel-lápis, na maioria das vezes individuais e anotados.

Em uma pedagogia das situações-problema ${ }^{13}$, o papel do aluno é implicar-se, participar de um esforço coletivo para elaborar um projeto e construir, na mesma ocasião, novas competências. Ele tem o direito a ensaios e erros e é convidado a expor suas dúvidas, a explicitar seus raciocínios, a tomar consciência de suas maneiras de aprender, de memorizar e de comunicar-se (1999, p. 65).
\end{abstract}

\title{
2.2.4 A Avaliação da Aprendizagem
}

Dentre as questões importantes a serem consideradas na abordagem por competências está a avaliação da aprendizagem. De acordo com PERRENOUD, "se a abordagem por competências não transformar os procedimentos de avaliação - o que é avaliado e como é

${ }^{13}$ Características de uma situação-problema, segundo ASTOLFI et al: "está organizada em torno da superação de um obstáculo pela classe, obstáculo este previamente identificado"; "deve oferecer uma resistência suficiente, que leve o aluno a investir seus conhecimentos anteriores disponíveis, bem como suas representações, de maneira que leve ao seu questionamento e à elaboração de novas idéias" (1997, p.144 apud PERRENOUD,1999, p. 58).

ASTOLFI et al. Mots-clés de la didactique des sciences. Repères, définitions, bibliographies, Bruxelas: De Boeck, 1997. 
avaliado - são poucas as suas chances de "seguir adiante"” (1999, p. 77). Na proposta do autor, quando os alunos aprendem através de situações-problemas ou em processos de projetos, eles

[...] estão, forçosamente, em situação de observação formativa ${ }^{14}$, sendo levados a confrontar suas maneiras de fazer e de dar-se feedback mutuamente. Neste caso, a avaliação não diz respeito ao adquirido, mas aos processos em curso, conforme uma seqüência de sucessivas interações, explicações e hesitações (PERRENOUD, 1999, p. 78).

Nesse contexto, o professor deve avaliar com base na comparação entre a tarefa a realizar, o que o aluno fez e o que faria se fosse mais competente, e não com base na comparação entre alunos. Assim, a partir

[...] do ponto de vista do professor, atenua-se a distinção entre o formativo e o certificativo, pois ele leva em consideração os mesmos indicadores de competências, em estágios diferentes de sua construção, ciente de que no fim do ano letivo ou do ciclo a avaliação será acima de tudo, certificativa (PERRENOUD, 1999, p. 78).

Para viabilizar essa proposta, é preciso que um outro contrato de avaliação seja negociado entre a instituição, o professor e os alunos.

GODOY (1995), no estudo sobre o estado da arte da avaliação da aprendizagem no ensino superior, menciona a proposta de avaliação inovadora que envolve os "contratos de aprendizagem"; caso em que "tanto as experiências de aprendizagem quanto os critérios de avaliação são negociados com os estudantes" (1995, p. 19).

O Alverno College, nos Estados Unidos, é reconhecido por sua experiência inovadora relacionada ao processo de avaliação, considerando que as

competências que os alunos devem desenvolver ${ }^{15}$ são freqüentemente avaliadas por meio de estratégias que vão além dos tradicionais exames escritos. Nesta

\footnotetext{
14 “A partir de uma opção que contempla como finalidade fundamental do ensino a formação integral da pessoa, e conforme uma concepção construtivista, a avaliação sempre tem que ser formativa, de maneira que o avaliador, independentemente de seu objeto de estudo, tem que observar as diferentes fases de uma intervenção que deverá ser estratégica" (ZABALA, 1998, p. 201); são elas: avaliação inicial, planejamento, adequação do plano (avaliação reguladora), avaliação final e avaliação integradora (estabelecimento de novas propostas de intervenção).

${ }^{15}$ A meta definida pelo Alverno College em relação às competências a serem desenvolvidas pelos alunos consiste em: desenvolver a comunicação, a capacidade analítica e de fazer julgamentos de valor, resolução de problemas, facilidade nas interações sociais, compreensão do relacionamento indivíduo-meio ambiente, do mundo contemporâneo e em relação às artes e humanidades (GODOY, 1995).
} 
experiência, o professor usa a avaliação visando principalmente à melhoria do desempenho dos alunos, ajudando-os a alcançarem níveis cada vez mais altos de competência. [...] Os contratos de aprendizagem são adotados e os docentes combinam com os alunos os resultados que deverão ser alcançados. Não existem notas no sentido tradicional, mas detalhadas avaliações qualitativas do desempenho dos alunos avaliados com base em critérios claramente estabelecidos sobre os resultados esperados. Também a auto-avaliação é enfatizada, pois todo o esforço é dirigido no sentido de ajudar o aluno a se tornar um aprendiz autônomo para o resto de sua vida (BOK ${ }^{16}, 1986$ apud GODOY, 1995, p. 19).

Sobre outros procedimentos de avaliação da aprendizagem, uma pesquisa identificou que, de acordo com a percepção dos alunos, "os testes objetivos de múltipla escolha ou de resposta breve são inadequados como indicadores de qualidade" (GODOY, 1995, p. 17). Dessa forma, outras opções mais adequadas e precisas para avaliação das realizações, do ponto de vista dos alunos, seriam: "as questões de ensaio, a organização de papers, os resultados de discussões em classe e as reuniões de orientação com docentes" (GODOY, 1995, p. 17).

Por outro lado, alguns processos de avaliação podem aumentar a carga de trabalho didático do professor, reforçando a importância de os professores utilizarem os resultados desses processos de forma competente, para capacitar os alunos a aprenderem com mais eficiência (GODOY, 1995).

De acordo com o relatório da Comissão Assessora para Educação Superior a Distância,

[...] na educação a distância, o modelo de avaliação da aprendizagem do aluno deve considerar seu ritmo [...]. A avaliação do aluno feita pelo professor deve somar-se à auto-avaliação, que auxilia o estudante a tornar-se mais autônomo, responsável, crítico, capaz de desenvolver sua independência intelectual (COMISSÃO..., 2002, p. 20).

Por fim, independente do procedimento de avaliação da aprendizagem escolhido, é muito importante que este esteja integrado e coerente com os objetivos de aprendizagem e os procedimentos de ensino (COMISSÃO..., 2002).

${ }^{16}$ BOK, D. Toward Higher Learning: The Importance of Assessing Outcomes. Change, v.18, n.6, p.18-27, 1986. 


\subsection{O e-Learning}

De acordo com o Decreto $N^{\circ} 2494$, de 10 de fevereiro de 1998, que regulamenta o Art. 80 da LDB,

Educação a distância é uma forma de ensino que possibilita a auto-aprendizagem, com mediação de recursos didáticos sistematicamente organizados, apresentados em diferentes suportes de informação, utilizados isoladamente ou combinados e veiculados pelos diversos meios de comunicação (BRASIL, 1998, p. 1).

MOORE, menciona que

A primeira tentativa em língua inglesa de definição e articulação de uma teoria da Educação a Distância surgiu em 1972. Mais tarde foi denominada de 'teoria da distância transacional'. Nesta primeira teoria afirmava-se que Educação a Distância não é uma simples separação geográfica entre alunos e professores, mas sim, e mais importante, um conceito pedagógico. É um conceito que descreve o universo de relações professor-aluno que se dão quando alunos e instrutores estão separados no espaço e/ou no tempo. Este universo de relações pode ser ordenado segundo uma tipologia construída em torno dos componentes mais elementares deste campo - a saber, a estrutura dos programas educacionais, a interação entre alunos e professores, e a natureza e o grau de autonomia do aluno (2002, p. 2).

Delimitando ainda mais esse conceito de educação a distância (EAD), VERDUIN e CLARK (1991, p. 11, tradução da autora) propõem quatro elementos para definir educação a distância:

1. Separação entre professor e aluno durante a maior parte do processo instrucional;

2. Influência de uma organização educacional, incluindo avaliação do aluno;

3. O uso de mídia educacional para unir professor e aluno e disponibilizar o conteúdo;

4. Disponibilidade de comunicação de duas vias entre professor, tutor, ou agente educacional e aluno.

Dentre as principais características da educação a distância é possível citar (NUNES, 1993, p. 6-16):

- Separação física entre professor e aluno;

- Utilização de meios técnicos de comunicação para transmitir o conteúdo e aproximar professor e aluno; 
- Previsão de uma comunicação de mão dupla entre professor e aluno, incluindo tutorias, orientações, observações sobre trabalhos realizados, esclarecimento de dúvidas e avaliações finais;

- Possibilidade de atender alunos relativamente dispersos (posição geográfica e/ou disponibilidade de horários);

- Alunos predominantemente adultos (possibilita valorização da experiência individual);

- Cursos auto-instrucionais (o centro do processo de ensino é o estudante, que precisa desenvolver habilidades de independência e iniciativa, aprendendo a partir do seu esforço individual e buscando o auto-desenvolvimento);

- Estudo individualizado (possibilidade de realizar o curso no ritmo desejado e de acordo com as características individuais do aluno);

- Cursos pré-produzidos (centralização da produção, que utiliza diversos meios e recursos como revistas, livros, rádio e televisão, filmes, computadores etc.);

- Comunicações massivas (vantagem de disponibilizar o curso para um grande número de alunos);

- Crescente utilização da tecnologia de informação;

- Tendência a adotar estruturas curriculares flexíveis (permite maior adaptação às possibilidades e expectativas individuais).

De acordo com ROSENBERG, e-learning "refere-se à utilização das tecnologias da Internet para fornecer um amplo conjunto de soluções que melhoram o conhecimento e o desempenho" (2002, p. 25). Assim, o e-learning pode ser considerado uma modalidade de educação a distância. $\mathrm{O}$ autor apresenta os três critérios fundamentais em que esse conceito está baseado:

1. Transmissão em rede, que possibilita atualização instantânea, arquivamento, distribuição e compartilhamento de instruções e informações;

2. Disponibilização via computador, utilizando os padrões de tecnologia da Internet;

3. Foco em uma visão ampla de aprendizado, soluções que vão além dos paradigmas tradicionais de treinamento. 


\subsubsection{O Histórico}

Segundo TODOROV (1994), a educação a distância nasceu sob o signo da democratização do saber, por tratar-se de uma inovação educativa que tem por objetivo gerar condições de acesso à educação para todos aqueles que não estejam sendo atendidos satisfatoriamente pelos meios tradicionais de ensino. O desafio para o futuro é pensar a educação a distância como parte das políticas instauradas para amenizar as desigualdades (LITWIN, 1999).

De acordo com NUNES (1993), as primeiras experiências com educação a distância foram realizadas no final do século XVIII, através do ensino por correspondência.

ROBERTS (1996) cita dois cursos a distância oferecidos no Canadá, com grande sucesso, entre os anos de 1880 e 1890 :

- William Rainey Harper, primeiro reitor e fundador da Universidade de Chicago, ofereceu um curso de hebraico por correspondência;

- Queen's College iniciou uma série de cursos a distância, com grande procura devido, principalmente, ao baixo custo e ao distanciamento entre os centros urbanos.

No início século XX, essas metodologias se desenvolveram e foram adaptadas a novos meios de comunicação de massa, principalmente o rádio. NUNES (1993) cita a experiência de KELLER $^{17}$ para ensino da recepção do Código Morse, durante a II Guerra Mundial.

De acordo com NUNES (1993), as experiências no Brasil com educação a distância foram iniciadas após a fundação do Instituto Rádio Monitor, em 1939, e do Instituto Universal Brasileiro, em 1941. O Movimento de Educação da Base (MEB) foi um dos primeiros projetos de destaque, com a preocupação de alfabetizar e apoiar a educação de jovens e adultos através das “escolas radiofônicas", principalmente no Norte e Nordeste do Brasil.

Um exemplo de sucesso de educação a distância no Brasil é o Telecurso 2000, atendendo a 500 mil alunos por ano através da televisão em circuito aberto e material impresso (LITTO, 2003).

\footnotetext{
${ }^{17}$ KELLER, F. Estudos sobre o Código Morse Internacional: um novo método para ensinar a recepção do código In: KERBAURY, Rachel R.(org). Keller. Coleção Grandes Cientistas Sociais, 41. São Paulo: Atica, 1983, p. 5968.
} 
Com o crescimento da Internet, os cursos a distância que utilizam este meio (cursos de e-learning) se disseminaram, tendo em vista o aumento da flexibilidade de comunicação entre o professor e o aluno.

Coerente com essa tendência, em 1996, é criada no Brasil a Secretaria de Educação a Distância (SEED), fundamentada na

[...] existência de um sistema tecnológico - cada vez mais barato, acessível e de manuseio mais simples - capaz de:

- trazer para a escola um enorme potencial didático-pedagógico;

- ampliar oportunidades onde os recursos são escassos;

- familiarizar o cidadão com a tecnologia que está em seu cotidiano;

- dar respostas flexíveis e personalizadas para pessoas que exigem diversidade maior de tipos de educação, informação e treinamento;

- oferecer meios de atualizar rapidamente o conhecimento;

- estender os espaços educacionais e;

- motivar os profissionais e alunos para aprender em continuamente, em qualquer estágio de suas vidas (SEED, 2002).

Também em 1996, a educação a distância no Brasil foi normatizada pela Lei de Diretrizes e Bases da Educação Nacional (Lei no 9394 de 20 de dezembro de 1996), oficializando sua utilização como modalidade válida para todos os níveis de ensino (VIANNEY, TORRES e SILVA, 2003).

Assim, os números da situação atual da educação a distância no Brasil (Quadro 7) indicam o crescimento ocorrido na última década, viabilizado pela criação da legislação em 1996, credenciamento de instituições e autorização de cursos, e pela pesquisa acadêmica gerando modelos pedagógicos e tecnologia (VIANNEY, TORRES e SILVA, 2003). O Quadro 7 também menciona algumas ações previstas do Ministério da Educação (MEC), visando à expansão da educação a distância. 
Quadro 7 - A Sala de Aula Virtual: Situação da Educação a Distância no País

\begin{tabular}{|c|c|}
\hline & $\begin{array}{c}\text { O QUE EXISTE HOJE NO } \\
\text { ENSINO SUPERIOR [A } \\
\text { DISTÂNCIA] }\end{array}$ \\
\hline$\checkmark$ & $\begin{array}{l}60 \text { cursos superiores, entre } \\
\text { graduação e pós-graduação latu } \\
\text { sensu }\end{array}$ \\
\hline$\checkmark$ & $\begin{array}{l}56 \text { deles em instituições públicas, } \\
\text { com } 99,01 \% \text { dos alunos }\end{array}$ \\
\hline$\checkmark$ & 84.397 alunos \\
\hline$\checkmark$ & $\begin{array}{l}67.024 \text { deles em cursos de } \\
\text { licenciatura }\end{array}$ \\
\hline$\checkmark$ & $\begin{array}{l}3 \text { instituições privadas oferecem } 4 \\
\text { cursos }\end{array}$ \\
\hline$\checkmark$ & $\begin{array}{l}4 \text { novos cursos de graduação em } \\
\text { instituições privadas foram } \\
\text { autorizados neste ano }\end{array}$ \\
\hline
\end{tabular}

\begin{tabular}{|ll|}
\hline \multicolumn{1}{|c|}{ O QUE PRETENDE O MEC } \\
\hline$\checkmark$ & 250 mil vagas em ensino superior a \\
& distância em 4 anos \\
$\checkmark$ & 10 mil delas neste ano [2003] \\
$\checkmark$ & 1 mil professores-tutores formados \\
& neste ano [2003] \\
$\checkmark$ & R\$ 600 milhões em investimentos \\
& em 4 anos \\
\hline \multicolumn{1}{|c|}{ NÚMEROS GERAIS } \\
\hline$\checkmark$ & $\begin{array}{l}1,2 \text { milhão de pessoas participam de } \\
\text { cursos a distância no País, em todos } \\
\text { os níveis de ensino }\end{array}$ \\
$\checkmark$ & $\begin{array}{l}\text { US\$ 80 milhões foram } \\
\text { movimentados por empresas no País } \\
\text { em 2002, em cursos de e-learning }\end{array}$ \\
\end{tabular}

Fonte: Livro a Universidade Virtual no Brasil, de João Vianney, Patrícia Torres e Elizabeth Silva, MEC e ABED apud CAFARDO (2003, p. A 14).

Para concluir este tópico sobre o histórico da educação a distância e, mais especificamente, do e-learning, é apresentado de forma resumida o modelo estruturado da evolução da educação a distância, considerando as diferentes tecnologias utilizadas.

De acordo com TAYLOR (2003), a evolução da educação a distância pode ser estruturada em cinco gerações: (1) Modelo Correspondência baseado na tecnologia impressa; (2) Modelo Multimídia, baseado nas tecnologias impressa, áudio e vídeo; (3) Modelo Teleducação ${ }^{18}$, baseado em tecnologias de telecomunicações que proporcionam oportunidades para a comunicação síncrona ${ }^{19}$; (4) Modelo de Aprendizagem Flexível, baseado na entrega online via Internet; (5) Modelo Inteligente de Aprendizagem Flexível, começa a surgir a partir da geração anterior, buscando maximizar a utilização de recursos da Internet e da Web. O Quadro 8 apresenta algumas características de cada modelo, incluindo um indicador relacionado com a variação do custo variável em função do aumento do volume de atividades.

18 Teleducação: "Termo utilizado como educação a distância, especialmente sistemas de EAD que utilizam a televisão ou o rádio como os principais meios de comunicação do conteúdo do curso" (ROMISZOWSKI e ROMISZOWSKI, 1998, p. 117). 
Quadro 8 - Modelos de Educação a Distância - Uma Estrutura Conceitual

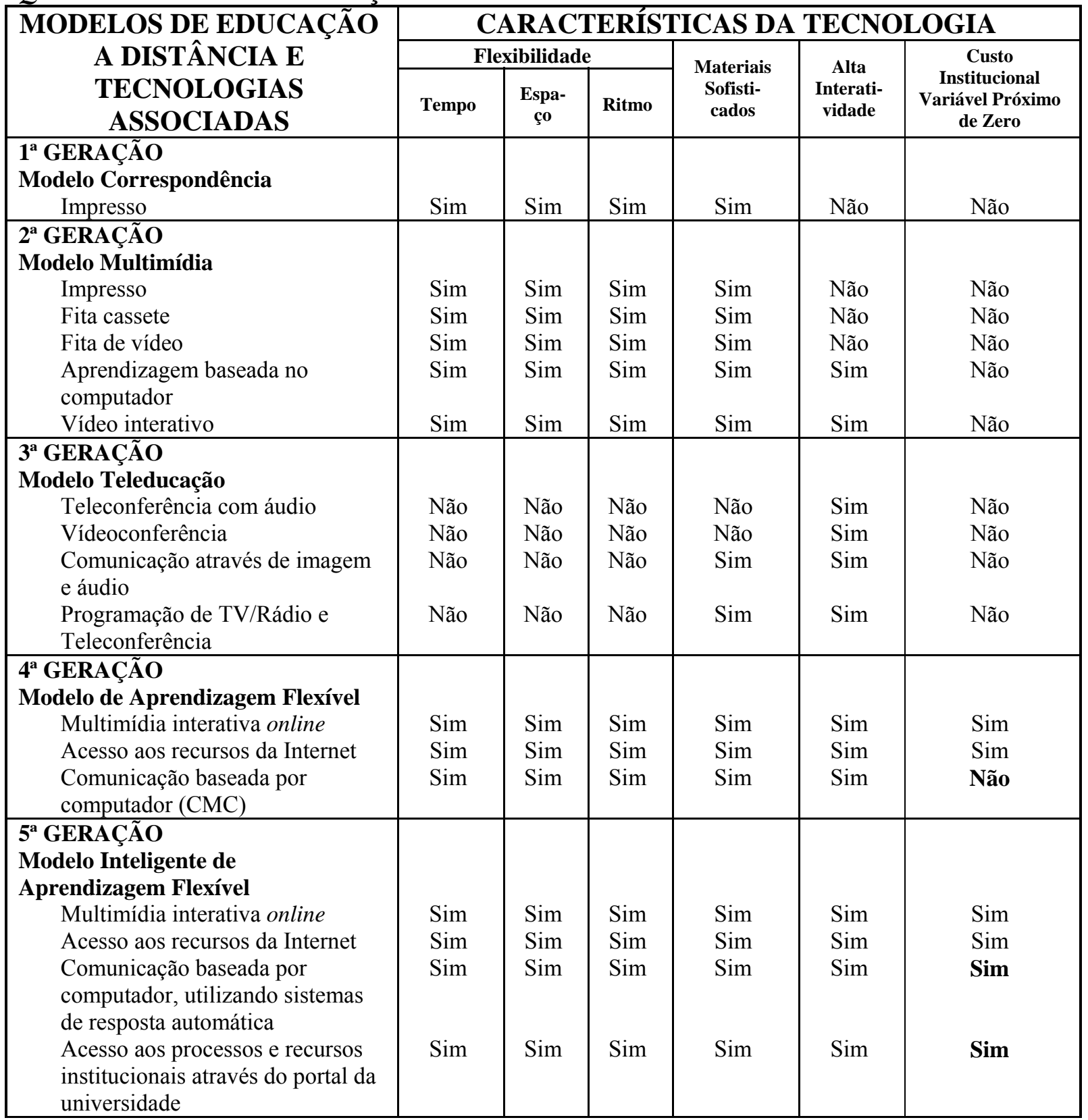

Fonte: TAYLOR (2003, p. 3, tradução da autora).

${ }^{19}$ Comunicação síncrona: processo de comunicação em que os "interlocutores estão fisicamente presentes ou remotamente conectados num mesmo ambiente, ao mesmo tempo, para que o processo se dê em tempo real, online ou presencialmente" (CHAVES, 2001). 


\subsubsection{Os Benefícios e os Problemas}

ROSENBERG (2002, p. 27-28) apresenta os benefícios do e-learning, alguns com foco no ambiente corporativo:

- Diminui os custos: minimiza custos com viagens, diminui o tempo para treinamento, reduz a necessidade de infra-estrutura;

- Melhora o nível de resposta do negócio: possibilita comunicar ilimitado número de pessoas virtualmente e simultaneamente (crítico quando há necessidade de mudar processos com rapidez);

- Mensagens consistentes ou customizadas, dependendo da necessidade: as pessoas recebem o mesmo conteúdo, apresentado da mesma forma. Além disso, os programas podem ser customizados de acordo com as necessidades das diferentes audiências;

- Conteúdo pode ser atualizado com facilidade e rapidez;

- Aprender 24 horas por dia e 7 dias por semana: Acesso de qualquer lugar em qualquer horário;

- Usuários familiarizados com Internet não terão dificuldades para acessar o curso;

- Universalidade: aproveitamento dos protocolos e browsers da Internet, que são universais;

- Construção de comunidades $^{20}$ : a Internet permite construir comunidades para compartilhar conhecimentos e insights após o curso;

- Escala: possibilidade de aumentar o número de alunos com um pequeno esforço e custo incremental;

- Aproveita investimentos realizados com as Intranets corporativas;

- Aumento do serviço ao cliente: o e-learning pode ajudar o consumidor a tirar maior proveito do site da organização.

Corroborando com ROSENBERG (2002), BROWN (2001) também menciona o grande potencial do ensino centrado no aluno e mediado por computador na formação de

\footnotetext{
${ }^{20}$ De acordo com Howard REINGHOLD, comunidades virtuais "são agregados sociais que surgem na Internet quando um número suficiente de pessoas leva adiante discussões públicas, longas o suficiente e com suficiente emoção, a ponto de estabelecer redes de relacionamento no ciberespaço" (apud CHAVES, 2001, p. 2). O livro do autor, "The Virtual Comunity: Homesteading at the Electronic Frontier", assim como outros textos estão disponíveis em seu site na Internet $<\mathrm{http}$ ://www.rheingold.com/vc/book>.
} 
comunidades virtuais, através das quais seus membros podem facilmente manter contato através da Internet, beneficiando não só os alunos (de forma pessoal, acadêmica ou ambos), mas também o departamento e a universidade através da rede de contatos estabelecida.

HUTCHINS (2001) menciona, entre as vantagens do e-learning, o contato com os recursos da informática e o incentivo à participação do aluno, tendo em vista que barreiras como preconceito, timidez e medo são mais facilmente deixados de lado.

Além disso, é possível estimular o desenvolvimento de habilidades através do ambiente online, como o pensamento crítico, a comunicação escrita e a resolução de problemas (ROVAI, 2002; MEYER, 2003; MURRAY e MASON, 2003), tendo em vista que as aulas online permitem que os alunos discutam assuntos mais polêmicos e participem igualmente em uma discussão mais cuidadosa e profunda dos temas (LANDIS, 2001; ONLINE..., 2003). O e-learning também ajuda a desenvolver habilidades relacionadas ao uso da tecnologia e da Internet (SPICELAND e HAWKINS, 2002; KRETOVICS e McCAMBRIDGE, 2002), cujo desenvolvimento em sala de aula é mais limitado.

Seguindo uma outra linha de pesquisa, SOELTL (2003) identificou, dentre as 13 organizações participantes da pesquisa, o estímulo ao auto-desenvolvimento como a principal razão interna à organização para a implantação do e-learning.

De acordo com PRETI,

autonomia, autoformação, autoaprendizagem, aprendizagem aberta, aprender a aprender, autoregulação, autopoiésis, etc. [são] terminologias diferentes que remetem a concepções e práticas diferenciadas, mas que têm em comum recolocar o aprendiz como sujeito, autor e condutor de seu processo de formação, apropriação, reelaboração e construção do conhecimento (2000, p. 5).

Assim, a "auto-aprendizagem é uma prática construída e consolidada em práticas e sistemas alternativos ${ }^{21}$, como a educação a distância, onde toda estrutura de suporte e procedimentos é posta para que aconteça o ato educativo e não a instrução" (PRETI, 2000, p. 12). Dessa forma, a educação a distância pode ser considerada mais flexível, estando pautada

\footnotetext{
${ }^{21}$ As características da educação alternativa são "ser participativa, partir da realidade e fundamentar-se na prática social do estudante, promover nos agentes do processo atitudes críticas e criativas, abrir caminhos à expressão e comunicação, promover processos e obter resultados, fundamentar-se na produção de conhecimentos, ser lúdica, prazerosa e bela, desenvolver atitudes de pesquisa" (GUITIÉRREZ PÉREZ e PRIETO CASTILHO, 1991 apud PRETI, 2000, p. 12). GUITIÉRREZ PÉREZ, F.; PRIETO CASTILHO, D. La mediación pedagógica: apuntes para una educación a distancia alternativa. San José, Costa Rica: Rádio Nederland Training Center, 1991.
} 
no paradigma da autoformação, fator que, dentre outros, explica seu crescimento (PRETI, 2000).

Corroborando, CERRI e BARUFI comentam que no ambiente virtual

[...] o aluno passa a ter um novo papel. Para ele, individualmente, o curso só existe se o acesso existir. Quantos acessos, a periodicidade deles, o exame mais ou menos demorado, a impressão ou não dos textos, a realização dos trabalhos, são algumas das decisões que deverá tomar. $\mathrm{O}$ ambiente virtual só existe para o aluno se ele acessar; o curso só se desenvolve se ele cumprir o que ficou estabelecido. Sua autonomia é clara e sua independência também. O aluno é fortemente responsável pela sua aprendizagem (2001, p. 20-21).

De acordo com DRUCKER, o ensino online "é mais flexível que a sala de aula, porque o estudante que não compreende o conteúdo de imediato pode rever o material. A interatividade do ensino online, sua facilidade de combinar imagens e gráficos com a palavra falada, lhe conferem uma vantagem em relação à sala de aula típica” (2000, p. 67).

Outra questão muito mencionada entre os benefícios do e-learning se refere à redução de custos se comparado à sala de aula, visto que o elevado investimento inicial pode ser compensado com o grande número de alunos (NUNES, 1993). Devido à dificuldade de encontrar autores que analisem esse aspecto no contexto das Instituições de Ensino, alguns aspectos, apresentados a seguir para ilustrar a discussão, se referem ao ambiente corporativo.

A Universidade Online da General Motors, que atende 88 mil funcionários de nível gerencial, profissional e técnico no mundo todo, estima que, para cada um dólar investido em e-learning, são economizados dois dólares em relação aos custos com o treinamento em sala de aula e mais um dólar em relação ao tempo de viagem ou de pessoal despendido (PANTAZIS, 2002).

De acordo com ROSENBERG (2002), a maior parcela de dinheiro economizada está relacionada ao custo de oportunidade dos "estudantes", ao invés dos custos com instrutor ou com viagem e moradia, embora estes também sejam verificados. Assim, a possibilidade do treinamento através do e-learning ter uma duração menor que em sala de aula impacta, positivamente, na produtividade dos funcionários, resultando em benefícios para a empresa. Além disso, a possibilidade de treinar um grande número de pessoas de uma vez também pode contribuir para a produtividade geral, considerando a agilidade obtida no processo. 
Por outro lado, algumas soluções podem reduzir o benefício financeiro devido ao aumento significativo do custo de fornecimento do treinamento, como é o caso da interação síncrona, que requer a presença do professor e de recursos de apoio (ROSENBERG, 2002). Mesmo a comunicação assíncrona ${ }^{22}$ também pode resultar em altos custos, tendo em vista a carga de trabalho envolvida por parte dos moderadores. Esse aspecto pode ser verificado na análise dos custos variáveis da comunicação mediada por computador proposta por TAYLOR (2003), que não tendem a diminuir em função do aumento do número de alunos, conforme apresentado no Quadro 8.

MURRAY e MASON também mencionam a limitação no ganho financeiro: "enquanto que a economia nos custos tem sido colocada em evidência como uma das razões para instituições educacionais e corporativas investirem em e-learning, os verdadeiros custos nem sempre estão aparentes" (2003, p. 17, tradução da autora). De acordo com os autores, é preciso considerar também os custos ocultos, como o acesso à Internet e a impressão de materiais pelos alunos. Complementando, FRYDENBERG (2002) chama a atenção para a vida útil limitada referente ao material disponível na Internet $(\mathrm{html})$, não sendo possível utilizá-lo por períodos muito longos sem incorrer em custos de manutenção.

Com o objetivo de auxiliar as instituições de ensino superior a planejarem melhor o custo envolvido na implantação de cursos através da Internet, MORGAN (2003) definiu seis categorias de custos que devem ser consideradas: custos com tecnologia; custos com pessoal de suporte (gestão do curso e suporte tecnológico); custos de treinamento do professor sobre como ensinar utilizando tecnologia; custos ocultos, como aumento do tráfego na rede, espaço físico para professores, tabulação e análise das avaliações e feedback; custos de desenvolvimento de cursos; e custos para implantação dos cursos. O autor também apresenta os investimentos realizados pela Marshall University em cursos online, de 1997 a 1999, totalizando US\$ 626,232 , dos quais $48 \%$ foram custos com desenvolvimento, $36 \%$ com oferecimento do curso e 16\% com tecnologia e infra-estrutura (MORGAN, 2003).

De forma geral, os benefícios obtidos com o e-learning dependerão muito das tecnologias e técnicas de ensino utilizadas, a serem definidas em função dos objetivos

\footnotetext{
${ }^{22}$ Comunicação assíncrona: processo de comunicação no qual a mensagem emitida por uma pessoa é recebida e respondida posteriormente (no próximo acesso ao ambiente virtual), visto que as pessoas não precisam estar simultaneamente conectadas, possibilitando a comunicação sem limitações de tempo e espaço geográfico (CHAVES, 2001; ROMISZOWSKI e ROMISZOWSKI, 1998).
} 
propostos e das necessidades dos alunos, que estão cada vez com menos tempo disponível e mais distantes geograficamente. Assim, para que estas vantagens sejam significativas, alguns desafios precisam ser vencidos.

Os resultados de uma pesquisa realizada com alunos de um curso através da Internet revelaram um dado importante: as persistentes frustrações dos alunos (HARA e KLING, 1999). De acordo com VASCONCELLOS e BERGAMASCHI (2001), alguns aspectos podem ser identificados como possíveis causas da frustração nas pessoas que utilizam os meios eletrônicos para interagir, seja em grupos virtuais ou em treinamentos a distância. Essas dificuldades podem levar à baixa participação ou até à desistência do aluno ou membro do grupo. A Figura 8, a seguir, apresenta um esquema com as causas da frustração e suas possíveis conseqüências.

Figura 8 - Problemas de Grupos e Equipes Virtuais

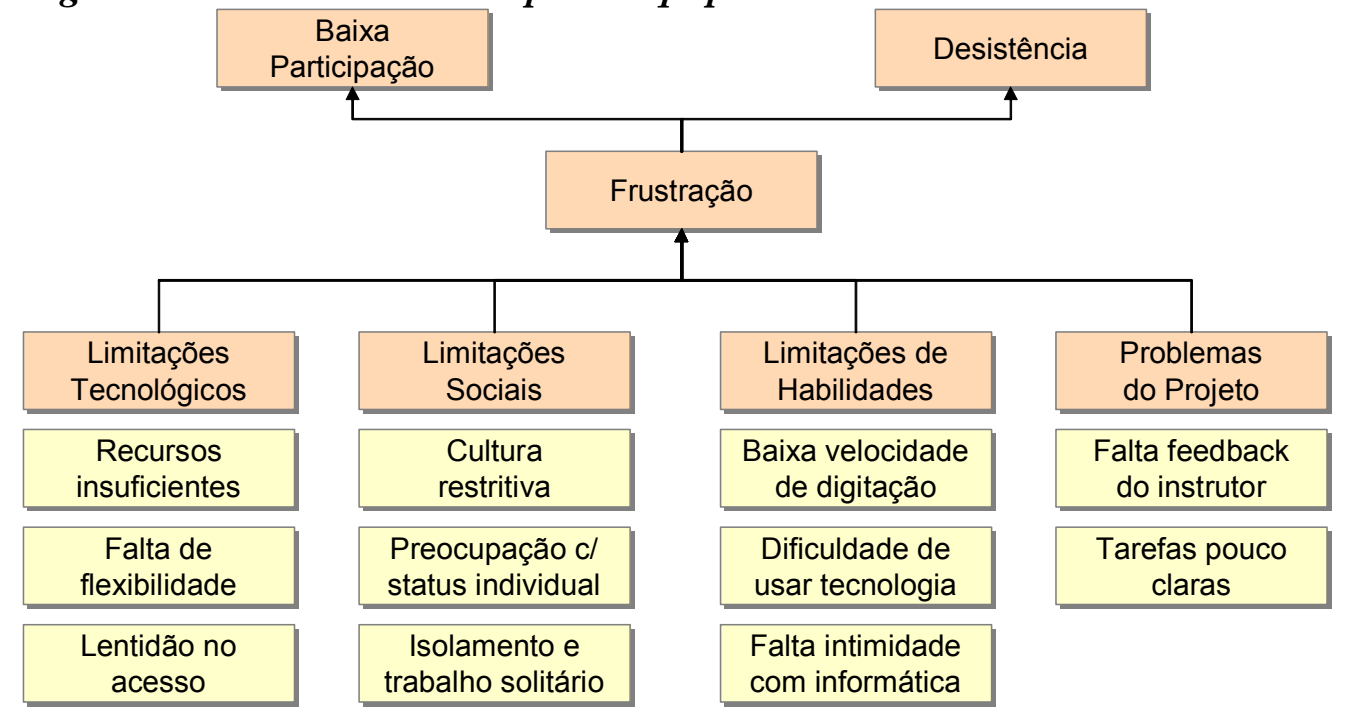

Fonte: VASCONCELLOS e BERGAMASCHI (2001, p.11).

Outra limitação significativa para utilização do e-learning é o acesso ao computador e à rede, ainda disponível para apenas um pequeno grupo de pessoas. De acordo com VIANNEY, TORRES e SILVA

o uso das novas tecnologias de comunicação e informação para a oferta de cursos on-line, ainda não se constitui como uma ferramenta suficiente para ampliar o atendimento e promover a democratização do ensino superior, permitindo o ingresso de parcelas da população até então impedidas de cursar a universidade. Em 2002, $87 \%$ das residências de classes média e média alta tinham acesso à Internet, contra apenas $12 \%$ dos domicílios das demais faixas de renda (2003, p. 7). 
Entre as principais barreiras do ensino individualizado e do uso de computadores no ensino, é possível citar (GODOY, 1997b, p. 112):

- dificuldade e falta de preparo dos docentes para abandonar seu papel tradicional de transmissor de informações e assumir a função de orientador;

- dificuldade de leitura e interpretação de textos;

- alto investimento inicial;

- dificuldade dos alunos serem promotores da sua aprendizagem;

- diálogo restrito entre aluno e professor;

- perda do aspecto social do aprendizado;

- recursos financeiros necessários para adquirir equipamentos.

Complementando, os resultados de um estudo de caso realizado em uma Instituição de Ensino Superior indicaram as principais dificuldades encontradas pelos alunos de pósgraduação em Administração na realização de atividades online como complemento das aulas presenciais: dificuldades para utilizar o software, baixa interatividade entre os participantes do curso e falta de tempo para realização das tarefas a distância (JACOBSOHN et al., 2002).

Na pesquisa realizada pela PricewaterhouseCoopers, em 2001, sobre o potencial do $e$ learning na América Latina, a cultura organizacional foi identificada como a maior barreira para implementação do e-learning. Dentre as razões apresentadas pela pesquisa para esse resultado estão o medo da mudança, a necessidade de atuação pró-ativa (ao invés de passiva) e a baixa alfabetização digital dos funcionários das empresas pesquisadas.

LANDIS (2001) menciona a importância da disciplina na participação de determinadas discussões online, em que o tempo e a presença ficam a critério do aluno; que, ao invés de comparecer na sala de aula, onde o professor conduz a maior parte do tempo, os alunos precisam participar e auxiliar na condução da própria aprendizagem, com o suporte do professor.

De acordo com OSIN, “as novas ferramentas, disponíveis graças à expansão da infraestrutura computacional e de comunicações, podem ser utilizadas para resolver os problemas do sistema educativo ou para perpetuá-los" (1999, p. 107, tradução da autora). Entre os problemas pedagógicos existentes é possível citar (OSIN, 1999):

- Heterogeneidade da população estudantil;

- Diferenças do tempo de aprendizagem; 
- Ensino como transferência de informação;

- Falta de adaptação do estudante;

- Possibilidades de expressão do estudante;

- Programa de estudos dissociado da vida real;

- Conhecimento inerte;

- Desconhecimento da pesquisa cognitiva (aprendizagem contextual, construtivismo e estrutura social da aprendizagem).

O autor também cita algumas limitações da educação a distância (OSIN, 1999): a pobreza do diálogo através do computador; o tempo escasso de contato entre estudante e computador; os benefícios não imediatos.

BRAGA (2002) analisa as justificativas para o e-learning ainda não ter decolado entre as Instituições de Ensino superior, dentre elas:

a) O conservadorismo e acomodação quanto aos métodos tradicionais de aprendizagem;

b) A falta de hábito, de conhecimento e afinidade quanto ao uso das tecnologias de $e$ learning;

c) A dificuldade das instituições de ensino em desenvolver a capacidade de aprenderem a aprender, gerando uma falta de autodidatismo por parte dos alunos;

d) $\mathrm{O}$ preconceito que relaciona o ensino a distância no Brasil a cursos de baixa qualidade.

Reforçando a importância da primeira dificuldade colocada por BRAGA (2002), BOTELHO comenta que o principal desafio para utilização do ensino a distância na Universidade "não diz respeito à tecnologia, mas sim à velocidade com que os professores assimilarão seu verdadeiro papel nas 'comunidades de aprendizado': serão facilitadores e tutores de capacitação, e não instrutores de disciplinas estanques" (2002, p. 12).

O Quadro 9, a seguir, resume, na opinião da autora, os benefícios e problemas do $e$ learning que poderão estar mais ou menos presentes, dependendo do contexto e da forma de utilização. 
Quadro 9-Benefícios e Problemas do e-learning

\begin{tabular}{|c|c|c|}
\hline $\begin{array}{l}\text { CATEGORIA } \\
\text { DE ANÁLISE }\end{array}$ & BENEFÍCIOS & PROBLEMAS \\
\hline $\begin{array}{l}\text { RECURSOS } \\
\text { FINAN- } \\
\text { CEIROS }\end{array}$ & $\begin{array}{l}\text { - Redução de custos com viagens, tempo } \\
\text { de deslocamento e infra-estrutura } \\
\text { - Ganhos com custo de oportunidade do } \\
\text { aluno decorrente da menor duração do } \\
\text { curso } \\
\text { - Aumento do } n^{\circ} \text { de alunos com baixo } \\
\text { custo incremental }\end{array}$ & $\begin{array}{l}\text { - Alto investimento inicial } \\
\text { - Investimento em equipamentos } \\
\text { - Estrutura para atendimento ao aluno } \\
\text { - Alto custo envolvido com } \\
\text { moderação (comunicação mediada } \\
\text { por computador) } \\
\text { - Consideração de custos ocultos }\end{array}$ \\
\hline $\begin{array}{l}\text { GESTÃO DO } \\
\text { CURSO }\end{array}$ & $\begin{array}{l}\text { - Uniformidade e consistência na } \\
\text { mensagem transmitida } \\
\text { - Disponibilização de informações mais } \\
\text { completas } \\
\text { - Facilidade e rapidez para atualização } \\
\text { - Adoção estruturas curriculares mais } \\
\text { flexíveis } \\
\text { - Treinamento de um grande número de } \\
\text { pessoas simultaneamente } \\
\text { - Aproveitamento dos padrões universais } \\
\text { da Internet }\end{array}$ & $\begin{array}{l}\text { - Falta de preparo dos professores } \\
\text { - Aumento da dedicação do professor } \\
\text { - Falta de clareza do conteúdo do } \\
\text { curso } \\
\text { - Falta de flexibilidade das } \\
\text { tecnologias }\end{array}$ \\
\hline $\begin{array}{l}\text { DINÂMICA } \\
\text { DO GRUPO }\end{array}$ & $\begin{array}{l}\text { - Integração de pessoas distantes } \\
\text { geograficamente } \\
\text { - Construção de comunidades virtuais }\end{array}$ & $\begin{array}{l}\text { - Limitação do aspecto social do } \\
\text { aprendizado } \\
\text { - Sentimento de isolamento e solidão }\end{array}$ \\
\hline ALUNO & $\begin{array}{l}\text { - Ritmo do curso adaptado ao aluno } \\
\text { - Acesso de qualquer lugar e a qualquer } \\
\text { hora } \\
\text { - Postura ativa frente ao próprio processo } \\
\text { de aprendizagem } \\
\text { - Incentivo a uma maior participação do } \\
\text { aluno } \\
\text { - Estímulo ao desenvolvimento do } \\
\text { pensamento crítico, comunicação } \\
\text { escrita, resolução de problemas e do } \\
\text { uso da informática e Internet }\end{array}$ & $\begin{array}{l}\text { - Dificuldade de leitura e } \\
\text { interpretação de textos } \\
\text { - Manutenção da postura passiva } \\
\text { - Medo da mudança } \\
\text { - Dificuldade para usar a tecnologia } \\
\text { - Baixa velocidade de digitação } \\
\text { - Limitações no acesso à Internet } \\
\text { - Falta de tempo }\end{array}$ \\
\hline
\end{tabular}

Organizado por JACOBSOHN, L. V.

Com base na análise sobre benefícios e limitações do e-learning e na discussão sobre a formação do administrador, foi possível definir algumas competências que essa metodologia de ensino teria potencial para desenvolver e que poderiam ser utilizadas nesta pesquisa.

Considerando as vantagens para o aluno, o e-learning pode ajudar no desenvolvimento da auto-aprendizagem, considerando a postura ativa que o estudante precisa assumir para viabilizar esse método de ensino (SOELTL, 2003; PRETI, 2000; CERRI e BARUFI, 2001). 
Por outro lado, a dificuldade de atuar em ambientes virtuais, baixa familiaridade com informática, consideradas como limitações na utilização do e-learning, transformam-se em oportunidade de crescimento, uma vez que o aluno passa a praticar a comunicação em ambientes virtuais (ROVAI, 2002; SPICELAND e HAWKINS, 2002; KRETOVICS e McCAMBRIDGE, 2002). De forma complementar, o aluno também tem mais oportunidades de expor suas opiniões e participar mais nas discussões (HUTCHINS, 2001; LANDIS, 2001; ONLINE..., 2003), visto que o ensino é mais individualizado e a comunicação virtual "permite maior liberdade de expressão a distância" (MORAN, 2000) e maior profundidade (LANDIS, 2001; ONLINE..., 2003), possibilitando o aprimoramento da competência de participação em discussões.

Ampliando o nível de análise para o grupo, o e-learning pode facilitar a formação de comunidades virtuais, espaços onde pessoas compartilham através da Internet conhecimentos e insights (ROSENBERG, 2002; BROWN 2001). A capacidade de formar e participar de comunidades virtuais está cada vez mais valorizada no ambiente corporativo, à medida que essas comunidades desempenham um papel importante na gestão do conhecimento organizacional ${ }^{23}$.

Dessa forma, a pesquisa empírica busca analisar o desenvolvimento dessas quatro competências, citadas acima. É importante ressaltar que a escolha das competências mencionadas na literatura se deu em função das atividades realizadas na disciplina estudada, e, apesar de a literatura mencionar o potencial do e-learning no desenvolvimento de outras competências, essas não serão abordadas nesta pesquisa.

Para facilitar a análise dos dados da pesquisa empírica, as competências pesquisadas foram agrupadas em três categorias: competências técnicas, competências de aprendizagem e competências sociais. Essa classificação foi adaptada da proposta de FLEURY e FLEURY (2001), apresentada no tópico sobre as competências do administrador (2.1.3), com uma diferença: os aspectos relacionados à atualização constante dos conhecimentos foram separados da categoria de Competências Técnicas, formando uma nova categoria denominada Competências de Aprendizagem.

\footnotetext{
23 “a gestão do conhecimento está imbricada nos processos de aprendizagem nas organizações e, assim, na conjugação desses três processos: aquisição e desenvolvimento de conhecimentos, disseminação e construção de memórias, em um processo coletivo de elaboração das competências necessárias à organização" (FLEURY e FLEURY, 2001, p. 33).
} 
Dessa forma, as Competências Técnicas se referem à futura utilização dos conhecimentos na realização das atividades profissionais (conhecimentos que são o foco da disciplina pesquisada); as Competências de Aprendizagem tratam da capacidade de atualização dos conhecimentos, incluindo a competência auto-aprendizagem; e as Competências Sociais estão relacionadas à interação com as pessoas, como é o caso da comunicação em ambientes virtuais, da participação em discussões e da formação de comunidades virtuais ${ }^{24}$.

\subsubsection{A Gestão Integrada da Educação a Distância}

TESTA, com base em nove entrevistas realizadas com especialistas e dois estudos de casos, identificou seis fatores críticos de sucesso para programas de educação a distância (EAD) via Internet, ou seja, questões que foram consideradas importantes ou geraram problemas nos casos estudados:

- Capacitação e experiência da equipe: "as pessoas envolvidas [...] devem ter experiência em educação a distância ou receber treinamento específico";

- Envolvimento dos membros da organização: "buscar o apoio de todas as pessoas da organização. E todos os membros da equipe, incluindo professores, deverão estar realmente envolvidos nas atividades do programa";

- Conhecimento e preocupação com as características e comportamento do estudante: “conhecer seus estudantes, para poderem desenvolver ações com o objetivo de atender suas necessidades, auxiliá-los na ambientação à Internet e a na disciplina para realizar as exigências dos cursos a distância, e evitar que se sintam abandonados ou isolados";

- Modelo pedagógico: “definir um projeto pedagógico, baseado na interação e colaboração, tendo especial cuidado com o design instrucional, evitando excessiva padronização e respeitando os fatores culturais dos estudantes";

24 A competência de formação de comunidades virtuais também poderia ser incluída na categoria de aprendizagem, pois possibilita a gestão do conhecimento. A opção por mantê-la junto com as competências sociais é justificada pela importância da interatividade para sua viabilização. 
- Tecnologia: “evitar focar na tecnologia, apesar de ser fundamental a avaliação da infra-estrutura tecnológica e dos softwares que compõe o ambiente de aprendizagem";

- Realização de parcerias (terceirização): "buscar parcerias estratégicas ou terceirizar parte de suas atividades" (2002, p. 103-105).

O modelo instrucional proposto por VERDUIN e CLARK (1991, p. 157) identifica os seis fatores principais a serem considerados na tomada de decisão para o planejamento e execução de experiências de aprendizado a distância (Figura 9). Os três primeiros fatores estão relacionados ao processo de planejamento, os dois fatores seguintes estão relacionados ao processo de aprendizado e interação e o fator final se refere à avaliação realizada pelo instrutor e/ ou pelo aluno. O objetivo desse modelo é identificar as variáveis e organizá-las em uma ordem lógica e não apresentar respostas diretas para as preocupações envolvidas em projetos dessa natureza.

\section{Figura 9 - Modelo Instrucional}

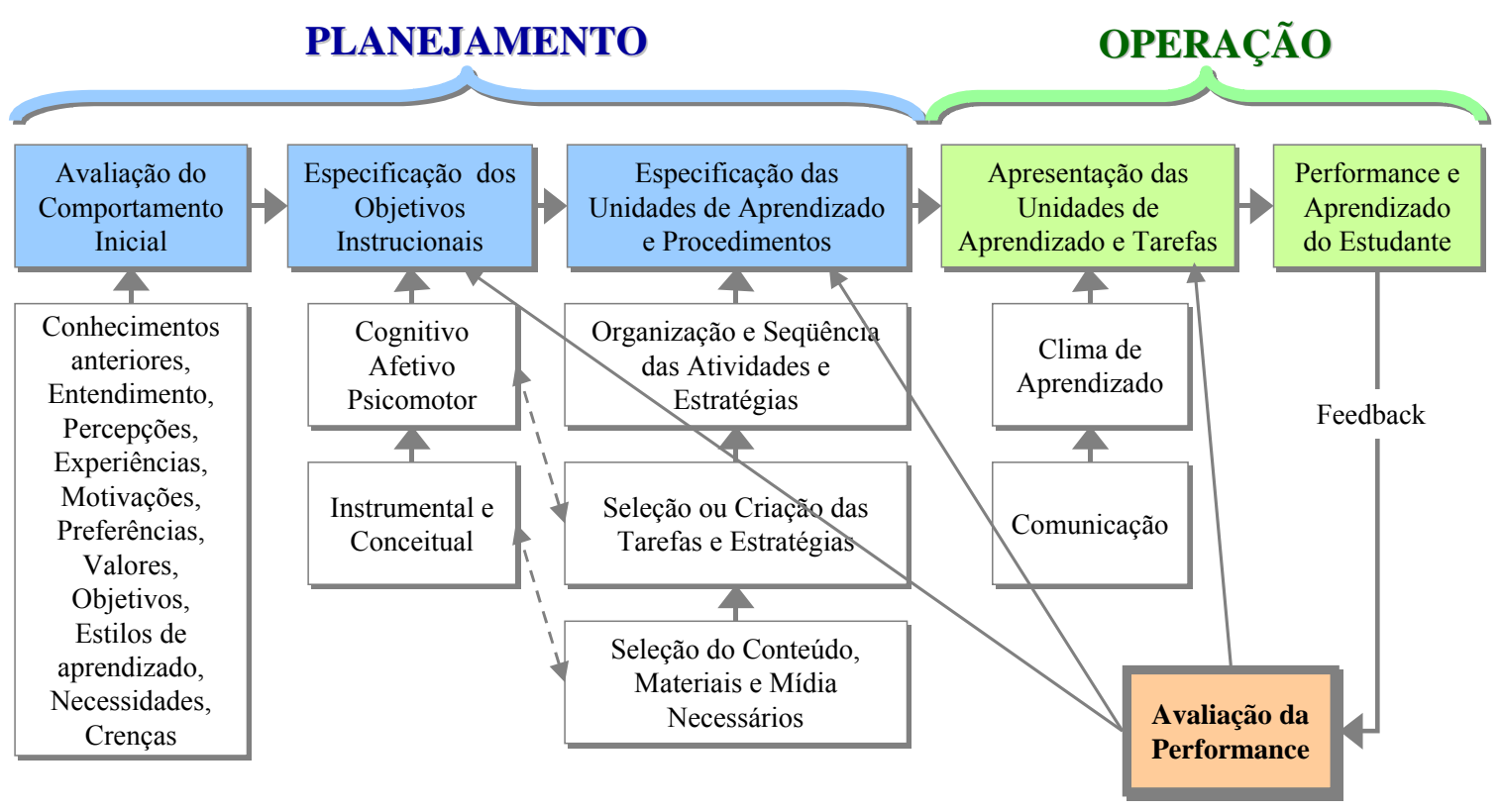

Fonte: VERDUIN e CLARK (1991, p. 157, tradução da autora).

Dentre os aspectos relacionados na etapa de avaliação do comportamento inicial do aluno (Figura 9 - modelo de VERDUIN e CLARK, 1991) é interessante notar a presença das preferências e do estilo de aprendizado dos alunos, visto que são fatores que podem auxiliar no planejamento dos objetivos e tarefas instrucionais. 
Considerando os aspectos gerenciais mencionados por TESTA (2002), como capacitação da equipe e parcerias, e o modelo instrucional proposto por VERDUIN e CLARK (1991), uma abordagem integrada é proposta para o gerenciamento das atividades de um curso a distância. A gestão integrada consiste em manter uma visão geral das atividades envolvidas no curso a distância e dos resultados esperados, compreendendo suas interrelações. A Figura 10 apresenta essa proposta, agrupando as atividades da gestão integrada da educação a distância, para fins didáticos, nas seguintes etapas: planejamento, execução, avaliação e implantação de melhorias. Cada uma dessas etapas produz um resultado: o curso a distância, a interação e aprendizado do aluno e as propostas de melhorias, respectivamente.

\section{Figura 10 - Gestão Integrada da Educação a Distância}

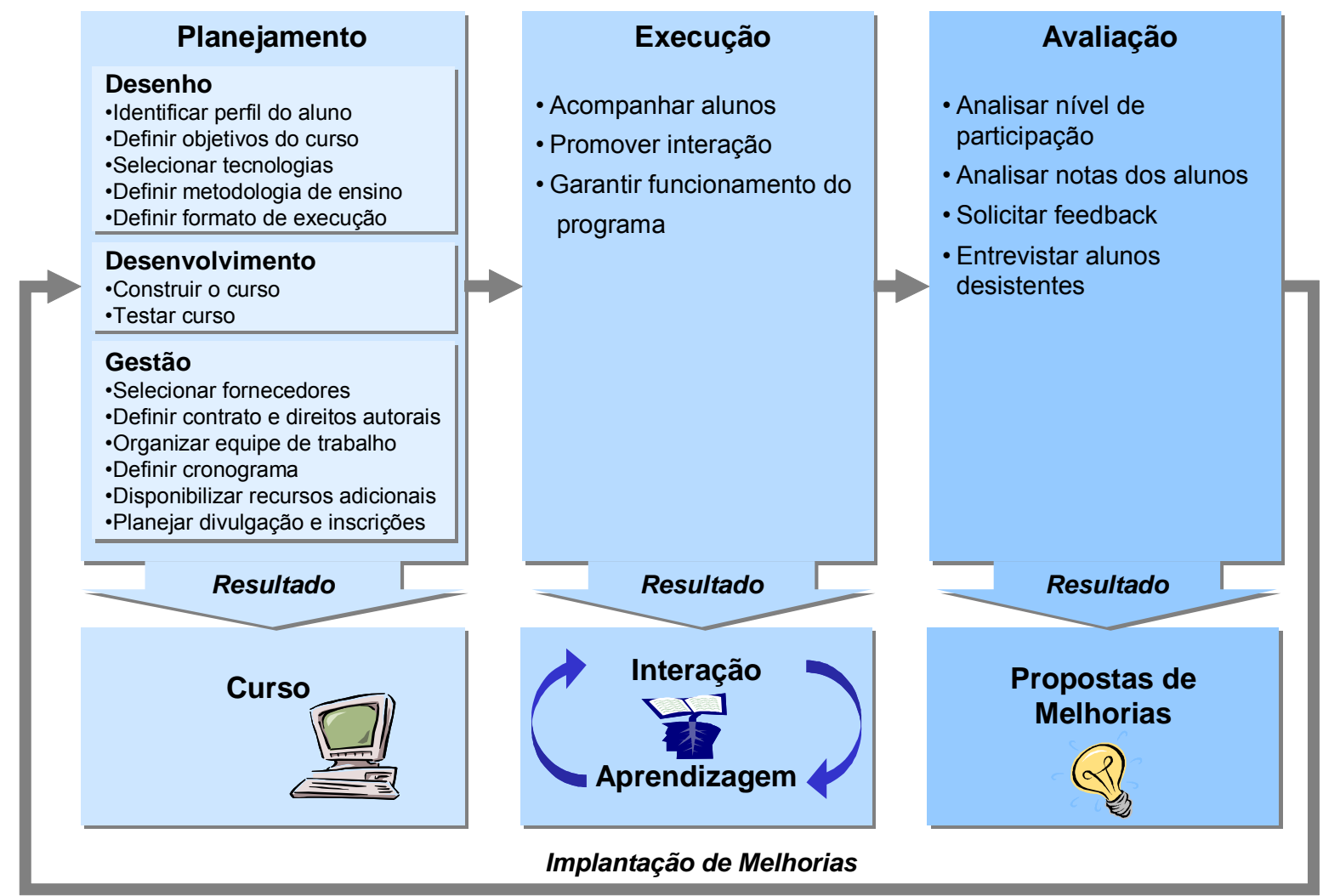

Organizado por JACOBSOHN, L. V.

A etapa de planejamento do curso pode ser dividida em três grandes grupos de atividades: desenho, desenvolvimento e gestão. As principais ações que integram a fase de desenho podem ser resumidas em: identificar o perfil do aluno; definir os objetivos do curso; selecionar as tecnologias; definir as técnicas de ensino; definir o formato da execução e avaliação. Nessa fase, busca-se desenvolver o curso tendo em vista a perspectiva do aluno, ao 
invés do conteúdo. Dessa forma, o conhecimento prévio do aluno, o que ele precisa saber, as condições que afetam o aprendizado e a avaliação são questões que devem ser consideradas.

Já a fase de desenvolvimento se refere à construção das telas e programas necessários para o curso, assim como dos testes de funcionalidades, conferência do conteúdo do curso e correção de problemas e erros identificados.

As atividades relacionadas à gestão ocorrem em paralelo às duas fases descritas anteriormente, são elas: selecionar fornecedores; definir contrato e direitos autorais; organizar e acompanhar a equipe de trabalho; definir e acompanhar o cronograma; disponibilizar e gerenciar recursos; planejar divulgação e inscrições.

Terminado o planejamento, o curso está pronto para ser disponibilizado, fase em que é realizado o acompanhamento dos alunos pelos tutores, que também são responsáveis por promover a interação entre os participantes do curso. A etapa seguinte (avaliação) é essencial para medir os resultados alcançados e possibilitar o aprimoramento contínuo do curso.

Tendo em mente o objetivo proposto de analisar a contribuição do e-learning no desenvolvimento de competências do administrador, no próximo tópico serão discutidas com maior detalhe as técnicas de ensino e recursos que podem ser utilizados através desse método de ensino.

\subsubsection{As Atividades de e-Learning}

De acordo com BORDENAVE e PEREIRA, para realizar os objetivos de aprendizagem propostos, o professor expõe os alunos a determinadas situações para que vivenciem experiências capazes de induzir o aprendizado. Para implementar esse processo o professor precisa estruturar "atividades, isto é, estabelecer ou promover situações de ensinoaprendizagem, em que haja uma alta probabilidade de que ditas experiências realmente aconteçam" (1995, p. 83-84). Embora o conceito de atividade seja equivalente ao método, procedimento ou técnica de ensino (já discutidas no tópico sobre aprendizagem), esse termo, proposto por BORDENAVE e PEREIRA (1995), possui uma conotação mais dinâmica e por isso foi escolhido para ser utilizado neste trabalho.

De acordo com JOY e GARCIA (2000), a obtenção dos resultados de aprendizagem depende de práticas pedagógicas efetivas. Assim, a questão principal a ser respondida no $e$ learning é “Qual a combinação de estratégias instrucionais e mídias que produzirá melhor os 
resultados de aprendizado para a audiência pretendida?” (JOY e GARCIA, 2000, p. 33, tradução da autora).

De acordo com o Dicionário de Terminologia de Educação a Distância, (ROMISZOWSKI e ROMISZOWSKI, 1998, p. 19), o conceito de mídia (ou meio de comunicação) pode ser "usado em dois sentidos: o processo de comunicação de informações entre os alunos e professores (meios auditivos, meios visuais, meios audiovisuais); os sistemas/materiais específicos" (papel, áudiocassete, rádio, televisão, videocassete, teleconferência com apenas áudio, videoconferência ${ }^{25}$, computador, Internet).

Dessa maneira, no planejamento das atividades instrucionais a distância é preciso escolher as mídias a serem utilizadas, conforme ilustrado na Figura 11. É importante ressaltar que essa figura é uma representação apenas esquemática, sendo que, na prática, as tecnologias acabam se misturando, como é o caso da teleconferência com áudio, inicialmente realizada através de aparelhos telefônicos específicos e hoje muito realizada através da Internet.

\section{Figura 11 - Mídias para disponibilizar ensino a distância}

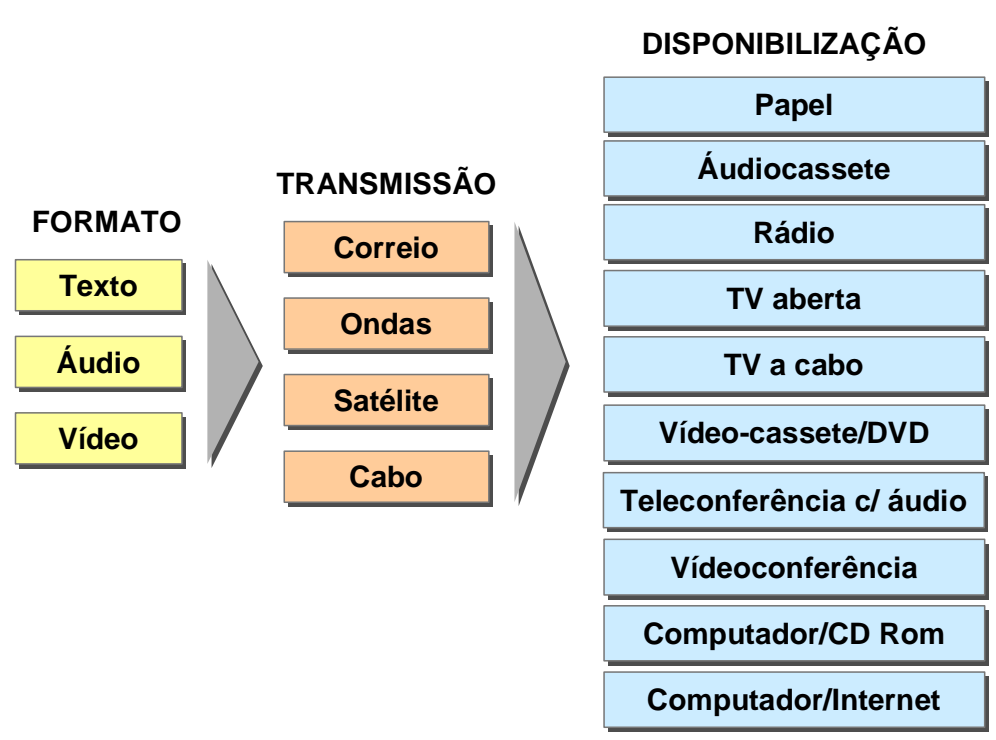

Organizado por JACOBSOHN, L. V.

Assim, considerando que as pessoas possuem diferentes estilos de aprendizagem, existe uma tendência de se utilizar formatos híbridos na realização de cursos a distância (blended learning); ou seja, utilizar mais de uma mídia, incluindo também a possibilidade de

25 Videoconferência: “conferência que reúne pessoas separadas pela distância e oferece a possibilidade comunicação audiovisual” (ROMISZOWSKI e ROMISZOWSKI, 1998, p. 123). 
realizar encontros presenciais periódicos. Esse formato permite aproveitar as vantagens de cada meio de comunicação, possibilitando um melhor atendimento das necessidades dos alunos. Assim, o curso híbrido tem sido mencionado na literatura como uma das tendências do e-learning (CAFARDO, 2003; FINN, 2002). De acordo com MURRAY e MASON (2003), a comunicação mediada por computador está cada vez mais presente nos cursos presenciais das instituições de ensino; possibilidade viabilizada no Brasil pela portaria do MEC (BRASIL, 2001, p. 1) que permite incluir métodos não presenciais nos cursos superiores reconhecidos (até $20 \%$ do tempo previsto para integralização do currículo).

Corroborando com JOY e GARCIA (2000), o estudo realizado por ROVAI "fornece evidências de que é o método e não a mídia que mais importa para um aprendizado efetivo" (2002, p. 1, tradução da autora); seguindo a mesma linha, MURRAY e MASON afirmam que "os resultados de aprendizagem estão mais relacionados com a forma como uma mídia em particular é utilizada do que com características intrínsecas da mídia em si” (2003, p. 7, tradução da autora). Esta questão é importante, pois transfere o foco da tecnologia de comunicação para a questão pedagógica, aspecto essencial da estratégia de e-learning.

O Quadro 10 apresenta uma descrição das atividades de e-learning que fizeram parte da pesquisa empírica deste trabalho; são elas: conteúdo, testes auto-corrigidos, WebQuest, Fórum e Chat. Apesar das atividades de e-learning estarem sendo tratadas neste estudo com o mesmo nome da ferramenta utilizada, elas não se limitam ao aspecto tecnológico, referindose, também, à situação de ensino proposta. A exceção é o WebQuest, que trata de uma atividade orientada de pesquisa na Internet.

Quadro 10 - Atividades de e-Learning

\begin{tabular}{|l|l|l|}
\hline ATIVIDADE & \multicolumn{1}{|c|}{ OBJETIVO } & \multicolumn{1}{c|}{ DESCRIÇÃO } \\
\hline Conteúdo & Compreensão da matéria & $\begin{array}{l}\text { Auto-estudo do material disponibilizado como } \\
\text { texto, transparências, áudio, vídeo, animações, } \\
\text { tutorial }\end{array}$ \\
\hline $\begin{array}{l}\text { Teste auto- } \\
\text { corrigido }\end{array}$ & $\begin{array}{l}\text { Revisão e aplicação do } \\
\text { conteúdo }\end{array}$ & $\begin{array}{l}\text { Conjunto de questões de múltipla escolha com } \\
\text { correção automática pelo software }\end{array}$ \\
\hline WebQuest & $\begin{array}{l}\text { Busca e análise de novas } \\
\text { informações }\end{array}$ & $\begin{array}{l}\text { Pesquisa orientada utilizando recursos da } \\
\text { Internet como ferramentas de busca e conteúdos } \\
\text { publicados }\end{array}$ \\
\hline Fórum & $\begin{array}{l}\text { Troca de opiniões e } \\
\text { construção colaborativa }\end{array}$ & $\begin{array}{l}\text { Local virtual para leitura e envio de mensagens } \\
\text { que são acessadas por todos no momento } \\
\text { desejado }\end{array}$ \\
\hline Chat & $\begin{array}{l}\text { Troca de opiniões e } \\
\text { construção colaborativa }\end{array}$ & $\begin{array}{l}\text { Local virtual para conversa entre os } \\
\text { participantes conectados simultaneamente }\end{array}$ \\
\hline
\end{tabular}


A seguir, são comentados aspectos importantes da utilização dessas atividades de $e$ learning, incluindo também os resultados de outras pesquisas.

Sobre a disponibilização de conteúdo através do e-learning, CERRI e BARUFI (2001) comentam a opinião dos alunos de um curso realizado inteiramente à distância no Instituto de Matemática e Estatística (IME) da USP em relação a esse aspecto. Na avaliação realizada, $90 \%$ dos alunos consideraram os textos disponibilizados online importantes e a maioria avaliou o material entre bom e ótimo, além de ter sido um recurso utilizado por todos os respondentes da pesquisa.

Ainda sobre essa pesquisa, realizada no IME/USP, de acordo com $85 \%$ dos alunos a realização e entrega dos exercícios propostos (entregues em papel ou disquete) ajudaram no estudo e preparação para as provas (CERRI e BARUFI, 2001); situação essa semelhante à que normalmente ocorre em cursos presenciais.

De acordo com o estudo realizado por DUTTON, DUTTON e PERRY (2002), a execução das atividades teve um impacto positivo nas notas e término do curso tanto dos alunos que participaram do curso online, quanto daqueles que cursaram a versão tradicional.

No caso específico da pesquisa na Internet, é necessário um modelo para orientação do aluno, tendo em vista a forma caótica com que as informações estão disponíveis na Web. Com o objetivo de ajudar o aluno a utilizar seu tempo do melhor modo, Bernie DODGE, professor da San Diego State University, criou o conceito de WebQuest: "uma investigação orientada na qual algumas ou todas as informações com as quais os aprendizes interagem são originadas de recursos da Internet [...]" (1995, p. 1).

Uma WebQuest deve conter (DODGE, 1995, p. 1): introdução fornecendo informações de fundo; tarefa factível e interessante; conjunto de fontes de informações necessárias para executar a tarefa; descrição do processo a ser realizado para completar a tarefa; orientações sobre como organizar a informação adquirida; conclusão que encerre a investigação.

De acordo com MARCH (1998), a Internet, conhecida por apresentar informações de forma caótica, sendo muitas inúteis, passa a ser um ótimo recurso do ponto de vista da aprendizagem ativa e com foco no aluno. Através da utilização da Web, o aluno precisa assumir a responsabilidade por seu próprio aprendizado, à medida que identifica as 
informações relevantes no todo disponível. Dessa forma, o modelo de WebQuest pode facilitar essa mudança, auxiliando os alunos a navegar pela rede.

Corroborando com essa afirmação, Bernie DODGE em entrevista para a World Education comenta os benefícios para os alunos provenientes da utilização de WebQuests:

O benefício de usar WebQuests, uma vez identificada a ocasião certa para utilização, é colocar mais responsabilidade nos próprios alunos. Este é um benefício chave para os alunos, porque idealmente eles vão obter alguma prática no processo de compreender novas informações, analisar dados de fontes diferentes do livro texto, adaptar a opinião de outros e organizar a si próprio e mutuamente para produzir algo que terá orgulho (STARR, 2000, tradução da autora).

Outra questão importante da utilização do e-learning é a interação entre o aluno e o professor e entre alunos, que, apesar de não ser novidade, tem sido considerada parte essencial no processo de aprendizagem. Dessa maneira, e-learning oferece novas possibilidades para o diálogo e a discussão, reduzindo as limitações da interação face-a-face, em tempo real. A comunicação mediada por computador ${ }^{26}$ (CMC - Computer Mediated Communication) pode trazer tanto vantagens quanto desvantagens, conforme apresentado no Quadro 11 (MURRAY e MASON, 2003).

Quadro 11 - Vantagens e Desvantagens da Comunicação Mediada por Computador

\begin{tabular}{|l|l|}
\hline \multicolumn{1}{|c|}{ VANTAGENS } & \multicolumn{1}{c|}{ DESVANTAGENS } \\
\hline Pode aumentar o nível de participação & $\begin{array}{l}\text { Normalmente baseada na comunicação escrita; não } \\
\text { possibilita linguagem corporal ou outras sugestões } \\
\text { visuais do significado }\end{array}$ \\
\hline Pode aumentar o envolvimento do aluno & $\begin{array}{l}\text { Há uma curva de aprendizagem do ambiente virtual } \\
\text { inevitável; as discussões podem demorar a começar }\end{array}$ \\
\hline $\begin{array}{l}\text { Estimula o aluno a assumir o papel de } \\
\text { tutor entre colegas e estimula a } \\
\text { aprendizagem entre colegas }\end{array}$ & O acesso a atividades online continua problemático \\
\hline $\begin{array}{l}\text { Promove uma abordagem centrada no } \\
\text { aluno }\end{array}$ & O estímulo à participação ativa pode ser difícil \\
\hline $\begin{array}{l}\text { Favorece compreensão e aprendizagem } \\
\text { profundas }\end{array}$ & $\begin{array}{l}\text { O gerenciamento de grandes volumes de discussão } \\
\text { pode exigir muito tempo de alunos e professores }\end{array}$ \\
\hline $\begin{array}{l}\text { Facilita o trabalho colaborativo } \\
\text { Pode ser necessário que o professor aprenda novas } \\
\text { habilidades de moderação online (ou adapte } \\
\text { habilidades existentes) }\end{array}$ \\
\hline $\begin{array}{l}\text { Possibilita disponibilizar os registros das } \\
\text { discussões }\end{array}$ & $\begin{array}{l}\text { O acúmulo de mensagens aumenta a sensação de } \\
\text { sobrecarga para alunos e professores }\end{array}$ \\
\hline
\end{tabular}

Fonte: MURRAY e MASON (2003, p.10, tradução da autora).

${ }^{26}$ A Comunicação Mediada por Computador é “o processo pelo qual pessoas criam, trocam e compreendem informação utilizando sistemas de rede de telecomunicações que facilitam a codificação, transmissão e decodificação das mensagens" (MURRAY e MASON, 2003, p. 3, tradução da autora). 
As interações online são muito diferentes daquelas estabelecidas na sala de aula, refletindo novos papéis na relação professor-aluno e diferentes estilos de redação e possibilitando seqüências de comunicação mais densas e profundas (LANDIS, 2001). As diferentes ferramentas de interação online, assim como seu funcionamento e suas principais características estão descritas no Quadro 12 (LANDIS, 2001).

Quadro 12 - Ferramentas do Curso Online

\begin{tabular}{|l|l|l|}
\hline FERRAMENTA & \multicolumn{1}{|c|}{ FUNCIONAMENTO } & \multicolumn{1}{c|}{ CARACTERÍSTICAS } \\
\hline E-mail & $\begin{array}{l}\text { Assíncrono, endereços de e-mail } \\
\text { individuais }\end{array}$ & $\begin{array}{l}\text { Direcionado para indivíduo ou } \\
\text { pequeno grupo; freqüentemente com } \\
\text { uma razão única }\end{array}$ \\
\hline Fórum & $\begin{array}{l}\text { Assíncrono, mensagens } \\
\text { organizadas por assunto em um } \\
\text { local central, normalmente as } \\
\text { respostas são encadeadas e } \\
\text { alinhadas uma abaixo da outra }\end{array}$ & $\begin{array}{l}\text { Histórico da interação é documentado } \\
\text { de forma contínua. Os títulos, estrutura } \\
\text { e a permanência dos registros podem } \\
\text { auxiliar na organização de conceitos e } \\
\text { distribuição de responsabilidades. }\end{array}$ \\
\hline Chat & $\begin{array}{l}\text { Síncrono, participantes acessam } \\
\text { um site central em uma hora } \\
\text { determinada. Normalmente um } \\
\text { interesse ou propósito comum é } \\
\text { compartilhado. }\end{array}$ & $\begin{array}{l}\text { Permite uma interação espontânea. } \\
\text { Várias conversas paralelas podem de } \\
\text { uma só vez, devido à defasagem no } \\
\text { tempo enquanto as pessoas estão } \\
\text { digitando. }\end{array}$ \\
\hline
\end{tabular}

Fonte: Adaptado de LANDIS (2001, p. 5, tradução da autora).

Cada ferramenta possui vantagens e desvantagens, várias dessas já apresentadas no Quadro 11. De acordo com LANDIS, enquanto o "Chat permite uma certa espontaneidade e interesse comum, característicos da interação face-a-face, o Fórum oferece uma oportunidade contínua para discussões mais profundas" (2001, p. 5, tradução da autora).

A pesquisa realizada por SPICELAND e HAWKINS (2002), utilizando a interação assíncrona com alunos de graduação da Universidade de Memphis, indicou que, como o aprendizado ativo envolve mais tempo, energia e auto-confiança do que aquele em sala de aula, os resultados limitados de aprendizado podem estar relacionados com a dificuldade de adaptação a essa nova forma de aprendizagem.

Quanto ao conteúdo das mensagens da comunicação mediada por computador, a pesquisa de $\mathrm{CHOU}$ com alunos de graduação mostrou que "um volume significativamente maior de interações relacionadas a conteúdos sociais e emocionais ocorreu nas discussões síncronas e um volume significativamente maior de interações orientadas para uma tarefa ocorreu nas discussões assíncronas” (2001, p. 77, tradução da autora). 
Analisando especificamente a utilização do Fórum, na pesquisa realizada por OLIVER e SHAW (2003), utilizando um ambiente de comunicação assíncrona como complemento das aulas tradicionais de um curso de medicina, a proporção de mensagens respondendo algum comentário foi de $30 \%$ do total enviado pelos alunos, resultando em um baixo nível de troca entre os participantes. Por outro lado, a proporção de mensagens enviadas pelo monitor foi muito alta, chegando a quase 50\% do total de mensagens do Fórum (OLIVER e SHAW, 2003).

SCHRUM e BENSON encontraram uma situação muito semelhante na utilização do Fórum pelos alunos de um MBA online, que "não produziu os resultados esperados [...] os alunos freqüentemente liam as questões dos professores e respondiam sem ler as respostas dos colegas, resultando em comentários lineares ao invés de uma discussão" (2000, p. 56, tradução da autora).

De acordo com a pesquisa realizada por OLIVER e SHAW, "o único elemento do contexto que pareceu influenciar o engajamento [dos alunos no Fórum] de forma importante foi o tutor" (2003, p. 65, tradução da autora); resultado também obtido por LANDIS (2001).

Reforçando a importância do tutor ou professor na interação através do Fórum, a análise estatística dos resultados da pesquisa de ARBAUGH (2000) com 97 alunos de um programa de MBA demonstrou que a atuação do instrutor, responsável por gerar e estimular a interação, estava fortemente associada ao aprendizado percebido pelos alunos. Da mesma forma, na experiência analisada por HARA e KLING (1999), a gestão da comunicação com os alunos, realizada pelo instrutor, destacou-se como aspecto chave, visto que a falta de feedback imediato e instruções ambíguas foram fonte de frustração nos estudantes.

Considerando a importância da atuação do professor nas discussões online, dois fatores precisam ser analisados com maior detalhe: a carga de trabalho necessária para acompanhar as discussões e o papel de moderador online.

Na experiência realizada por REINHARD, YONEZAWA e MORGADO (2000), os alunos valorizaram muito o suporte do professor e sua equipe, que dedicaram um total de 100 horas de suporte durante todo o curso (23 dias), resultando em uma média de 4,3 horas por dia.

SCHRUM e BENSON identificaram a dedicação necessária para realizar um bom trabalho como a principal preocupação dos professores envolvidos no curso de MBA online. 
Conforme comentado por um dos professores: "Eu acho que tem funcionado muito melhor do que eu esperava, porém [...] o custo foi que eu gastei 40-60 horas por semana para um curso de duas horas" (2000, p. 57).

Além da dedicação, de acordo com SPECTOR e LA TEJA, para ser um efetivo moderador online é preciso dominar habilidades específicas. No caso das discussões online assíncronas o moderador precisa "(1) permitir aos alunos tempo para reflexão, (2) manter as discussões vivas e em uma linha produtiva e (3) arquivar e organizar as discussões para usar em lições seguintes" (2001, p. 2, tradução da autora). Já as habilidades para moderar discussões online síncronas envolvem "(1) estabelecer regras básicas para a discussão, (2) estimular as interações com mínima intervenção, (3) perceber como as mensagens de texto podem apresentar-se aos alunos distantes e (4) estar atento às diferenças culturais" (SPECTOR e LA TEJA, 2001, p. 2, tradução da autora).

Complementando as habilidades do professor online, GUNN (2001) menciona as seguintes: auxiliar no esclarecimento de papéis e responsabilidade, gestão do tempo e expectativas; facilitar, moderar, motivar e promover participação; responder prontamente e fornecer feedback apropriado (construtivo); promover e ajudar no desenvolvimento de habilidades técnicas adequadas para utilizar o ambiente e ferramentas; prover materiais e atividades adequados para acomodar todos os estilos de aprendizagem; promover e estimular a auto-gestão e responsabilidade; avaliar, rever e modificar as práticas de ensino de acordo com o feedback (GUNN, 2001).

Sobre o Chat, CHAVES comenta algumas vantagens dessa atividade:

A interação que ocorre em encontros síncronos via Internet é de grande riqueza pois propicia a criação de laços sociais, oferece momentos para a criação de materiais coletivos, brainstorming e tomada de decisões. Surge um senso de envolvimento e engajamento que é crítico na construção de uma comunidade de aprendizagem. A sensação de presença social existe, já que acontece em tempo real (há alguém ao vivo do outro lado da tela), vivencia-se uma experiência de fluxo, onde a ação e atenção caminham juntas; não se percebe o tempo passar e o engajamento é profundo (2001, p. 7).

Por outro lado, dentre as principais limitações do uso de Chats com fins instrucionais estão: inadequado para exposições longas e palestras; dificuldades com horário (participantes que morem em regiões com diferentes fusos horários, ou os que só podem acessar a Internet em determinados horários); dificuldade para discutir em grupos muito grandes e não 
moderados; participantes com baixa habilidade de digitação, pouca familiaridade com o ferramental, dificuldade em digitar e simultaneamente ler as mensagens na tela (CHAVES, 2001).

De acordo com HILTZ, estudos que comparam encontros presenciais e virtuais concluem que "mais opiniões tendem a ser solicitadas e oferecidas em conferências online [...]. Entretanto, a democracia, se aproximando da anarquia, que caracteriza a comunicação mediada por computador desestruturada ou 'discussão livre' torna difícil para os grupos chegarem a um consenso sobre assuntos ou problemas complexos" $(1994$, p. 28 , tradução da autora).

Retomando a questão das comunidades virtuais, apresentada como uma das vantagens do e-learning, ROVAI (2002) pesquisou as diferenças entre a comunidade formada por alunos do curso presencial e por alunos do curso online assíncrono (Asyncchronous Learning Network), através do Índice de Percepção de Comunidade em Sala de Aula (Sense of Classroom Community Index). Participaram da pesquisa 326 alunos adultos, matriculados em cursos de graduação e pós-graduação em duas universidades. $\mathrm{O}$ autor verificou que não existe diferença significativa no sentimento geral da comunidade formada por alunos nos dois formatos de curso. Inclusive, em alguns cursos, os alunos de e-learning tiveram um senso de comunidade maior que nos cursos presenciais. De acordo com o autor, esse resultado sugere que o sentimento de isolamento relatado em vários cursos tende a estar relacionado ao formato e pedagogia de cada curso ao invés do sistema de e-learning como um todo. Como resultado, foi verificada uma maior variabilidade nas comunidades formadas a distância, indicando que a comunidade online é mais sensível ao formato e pedagogia do curso de $e$ learning do que no caso de aulas presenciais.

Além disso, ROVAI (2002) menciona que o ambiente de e-learning requer mais atenção e esforço tanto do professor quanto dos alunos para que as interações ocorram. Os resultados mostram uma relação positiva entre a formação de comunidade e o número de mensagens enviadas no sistema de e-learning, confirmando a importância da interatividade como componente para a construção da comunidade. Os dados também sugerem que instrutores experientes no ambiente online conseguem criar e manter níveis de comunidade que são no mínimo iguais àqueles verificados na sala de aula presencial. 
A discussão sobre as atividades de e-learning realizada neste tópico possibilita incluir a pesquisa na Internet, estimulada através do WebQuest, dentre as competências que o $e$ learning pode ajudar a desenvolver, complementando aquelas já comentadas no tópico 2.3.2 e fechando em cinco o número de competências a serem analisadas na pesquisa empírica. Sendo assim, a pesquisa na Internet pode ser incluída na categoria Competências de Aprendizagem, junto com a auto-aprendizagem.

\subsubsection{O e-Learning Aplicado ao Ensino da Administração}

Experiências de utilização do e-learning têm sido realizadas para ensino nas diversas áreas do conhecimento. Com o objetivo apenas de ilustrar a utilização do e-learning no ensino da Administração, no Mundo e no Brasil, a seguir serão comentadas algumas dessas experiências que foram transformadas em objeto de pesquisa científica. Os resultados dessas experiências relevantes para fundamentar esta pesquisa já foram comentados nos tópicos anteriores da revisão bibliográfica ou serão mencionados no capítulo de análise de resultados.

\section{No Mundo}

- MBA híbrido: desenvolvido em parceria por uma Faculdade de Administração americana e uma empresa, com duração de 2 anos, sendo $50 \%$ realizado no formato presencial e 50\% online. A pesquisa realizada por SCHRUM e BENSON (2000) analisa o primeiro semestre do curso com base no ponto de vista do professor, da administração e do aluno.

- MBA online: oferecido totalmente a distância, por uma Universidade baseada nos Estados Unidos, através de software para troca de materiais, discussões e trabalho em grupo e do envio de gravações das aulas realizadas em classe. A pesquisa desenvolvida por KRETOVICS e McCAMBRIDGE (2002) compara essa modalidade com o formato presencial.

- Programa de MBA online da Athabasca University (Canadá): pesquisa compara o formato online com o presencial em atividades de estudo de caso (ATHABASCA, 2001).

- Disciplinas online do programa de MBA da University of Wisconsin Oshkosh: foram analisadas cinco disciplinas online do programa, das quais os alunos também 
participavam de outras disciplinas no formato presencial. ARBAUGH (2000) examinou os efeitos das características tecnológicas, pedagógicas e do aluno no aprendizado.

- Simulação sobre estilos de liderança e ética na Texas A\&M University (EUA): experimento realizado utilizando um modelo de simulação em CD-ROM como complemento às aulas presenciais (BOYD e MURPHREY, 2002).

- Curso online de planejamento estratégico: aplicação desenvolvida pela University of Las Palmas de Gran Canária (Espanha) para disponibilizar conteúdos sobre o tema e possibilitar interação dos alunos (OSORIO; RUBIO-ROYO e OCÓN, 1999).

\section{No Brasil}

- Curso "Eficiência em Reuniões": experimento realizado por YONEZAWA (2000) em sua tese de doutorado, que constituiu no oferecimento de um curso a distância utilizando comunicação mediada por computador (CMC) integrada a um ambiente de e-learning.

- Software de apoio para disciplina de Marketing na Universidade Estadual de Londrina: "sistema que combina a tecnologia do estudo de caso com a interatividade do computador" (SOUZA, LOPES e GUAGLIARDI, 1998:1), desenvolvido no Departamento de Administração da Universidade Estadual de Londrina.

- Disciplina sistemas de informações gerenciais na Universidade Federal do Rio Grande do Sul: disciplina realizada virtualmente com algumas aulas presenciais. A pesquisa analisou a utilização da Internet como mecanismo de ensino-aprendizagem, através de uma dinâmica de grupo (CAVEDON, RECH e CANO, 2002).

- Disciplina de estatística em formato semi-presencial na Faculdade de Economia, Administração e Contabilidade de Ribeirão Preto da USP (FEARP-USP): NORONHA e VIEIRA (2002) apresentam o planejamento dessa disciplina do curso de Administração, no formato semi-presencial.

Apesar de ainda não terem sido objeto de pesquisa científica, duas outras experiências complementam a análise da utilização do e-learning no ensino da Administração: o lançamento do primeiro curso de graduação em Administração de Empresas na modalidade de educação a distância e o Desafio Sebrae 2003. 
O curso de graduação a distância em Administração é oferecido pela Faculdade de Administração de Brasília (FAAB), instituição mantida pela Associação Internacional de Educação Continuada (AIE) e foi aprovado pelo MEC (Ministério da Educação) através da portaria $\mathrm{N}^{\mathrm{o}} 1.604$, de 24 de julho de $2001^{27}$. Para a turma com início no segundo semestre de 2003, foram abertas 900 vagas, a serem distribuídas conforme a demanda dos Centros Regionais de: Belém, Belo Horizonte, Brasília, Curitiba, Fortaleza, Manaus, Salvador, Recife, Rio de Janeiro e São Paulo. A Tabela 1 mostra a distribuição dos 688 alunos aprovados no processo seletivo para o curso de administração a distância da FAAB, por Centro Regional (AIEC, 2003).

Tabela 1 - Número de Alunos Aprovados no Processo Seletivo do Curso de Administração a Distância na FAAB, por Centro Regional

\begin{tabular}{lcc}
\hline \multicolumn{1}{c}{ Centro Regional } & Número de Alunos Aprovados & \% do Total de Aprovados \\
\hline Belém & 232 & $34 \%$ \\
Brasília & 136 & $20 \%$ \\
São Paulo & 78 & $11 \%$ \\
Manaus & 70 & $10 \%$ \\
Salvador & 65 & $9 \%$ \\
Belo Horizonte & 34 & $5 \%$ \\
Curitiba & 34 & $5 \%$ \\
Recife & 20 & $3 \%$ \\
Rio de Janeiro & 12 & $2 \%$ \\
Fortaleza & 7 & $1 \%$ \\
\hline TOTAL & 688 & $100 \%$ \\
\hline
\end{tabular}

A seguir, algumas informações sobre o curso e a estratégia de ensino utilizada:

- Duração de 8 semestres, totalizando 3330 horas-aula;

- Modalidade de educação a distância semi-presencial, utilizando a Internet e a sala de aula;

- Turmas compostas por 50 alunos, que se reúnem mensalmente nos Centros Regionais, de forma presencial, para discutir casos ou realizar atividades práticas, sob a orientação do tutor;

\footnotetext{
${ }^{27}$ Em 2003, o Instituto UVB.BR obteve aprovação do MEC para oferecimento do curso de graduação a distância em administração através da Portaria $\mathrm{n}^{\circ}$ 1068/03 (MEC, 2003). O lançamento do curso está previsto para 2004, com um oferecimento de 600 vagas por semestre (IUVB.BR, 2003).
} 
- Cada aluno participa de um pequeno grupo, onde a interação pode ser feita por e-mail, Fórum, Chat ou telefone, com o objetivo de debater os temas do conteúdo, preparar os casos para discussão e auxiliar colegas em possíveis dúvidas;

- O conteúdo das disciplinas e as orientações de estudo são disponibilizados na Internet;

- Cada disciplina é dividida em unidades de ensino que apresentam os textos básicos para estudo individual, exercícios auto-corrigidos, leituras adicionais e casos;

- A avaliação da aprendizagem é realizada através das provas presenciais e da participação nas discussões e trabalho nos grandes e pequenos grupos.

Complementando a descrição de experiências, o Desafio Sebrae 2003 consiste em um jogo de empresas realizado pela Internet, com o objetivo de contribuir na formação de futuros empreendedores, através da aplicação prática dos conceitos envolvidos na gestão de um negócio. Assim, as equipes participantes têm a oportunidade de dirigir uma empresa, tomando decisões em todas as áreas - desde o preço dos produtos, passando pelo investimento em marketing e qualidade, até a compra de matérias-primas.

O Desafio Sebrae 2003 é a quarta edição da competição, sendo observado nas edições anteriores um crescimento acentuado no número de equipes participantes: na estréia foram 200 equipes inscritas, em 2001 foram 3.200 equipes e em 2002 participaram 10.000 equipes. A seguir, mais alguns detalhes interessantes sobre a competição:

- Público-alvo: alunos matriculados em qualquer curso de graduação credenciado pelo MEC;

- Equipe: deve ter no mínimo 3 e no máximo 5 integrantes, que podem ser de instituições de ensino e cursos diferentes mas do mesmo Estado e, se possível, da mesma cidade, para facilitar a tomada de decisões;

- Preparação: trata-se de uma gincana de perguntas e respostas sobre empreendedorismo e cultura geral (facultativo). Esse período deve ser aproveitado para a leitura detalhada do manual, o planejamento de estratégias e a divisão de funções.

- Funcionamento: é utilizado um software que apresenta um cenário virtual de uma empresa, através do qual os participantes tomam decisões e gerenciam o negócio. Nas duas últimas etapas, a competição deixa de ser virtual e passa a ser presencial, incluindo também situações de convivência, prazos e trabalho em equipe. 
As experiências relatadas neste tópico ilustram as diferentes abordagens em que o $e$ learning pode ser utilizado no ensino da Administração, reafirmando o potencial desse método de ensino; seja para atender alunos distantes ou com limitações de horário, seja para promover outras dinâmicas de aprendizagem e desenvolvimento de outras competências. 


\section{METODOLOGIA DA PESQUISA}

A realização deste projeto de dissertação dividiu-se em duas fases. Na primeira fase, apresentada nos dois capítulos iniciais, foi conduzida uma pesquisa bibliográfica sobre os aspectos relacionados ao estudo: formação do administrador, aprendizagem e $e$-learning. A partir das informações levantadas, foi implementada a segunda fase, que consistiu no levantamento de dados primários, através do método do estudo de caso.

Conforme já mencionado na página 5, o objetivo geral desta pesquisa é analisar a contribuição do e-learning, como atividade complementar do curso de graduação, para o desenvolvimento de competências do administrador, com base no conceito de Competência de Formação ${ }^{28}$, resultando nos seguintes objetivos específicos:

1. Identificar a contribuição das atividades de e-learning (conteúdo, testes autocorrigidos, WebQuest, Fórum e Chat) para o desenvolvimento de competências técnicas, foco da disciplina Administração de RH I;

2. Analisar a contribuição do e-learning no desenvolvimento de competências de aprendizagem e competências sociais;

3. Discutir a influência do estilo de aprendizagem do aluno na utilização do e-learning para o desenvolvimento de competências do administrador, acima citadas (técnicas, de aprendizagem e sociais).

As escolhas metodológicas realizadas neste estudo foram norteadas pelo caráter exploratório do trabalho, tendo em vista o tema abordado e os objetivos propostos.

De acordo com MATTAR (1999, p. 79), para a classificação da pesquisa é preciso considerar duas variáveis: (1) “o objetivo e grau em que o problema de pesquisa está cristalizado" e (2) "a natureza do relacionamento entre as variáveis estudadas". As categorias resultantes são: pesquisa exploratória, pesquisa conclusiva descritiva e pesquisa conclusiva causal.

\footnotetext{
${ }^{28}$ Competências de Formação são atributos ou qualidades humanas, obtidas por aprendizagem, do profissional que a Instituição de Ensino Superior deseja formar, tendo em vista a ação na situação de trabalho futura" (AMATUCCI, 2000, p. 85).
} 
Dessa forma, MATTAR discute os objetivos e características da pesquisa exploratória:

A pesquisa exploratória visa prover o pesquisador de maior conhecimento sobre o tema ou problema de pesquisa em perspectiva. Por isso é, apropriada para os primeiros estágios da investigação quando a familiaridade, o conhecimento e a compreensão do fenômeno por parte do investigador são, geralmente, insuficientes ou inexistentes (1999, p. 80).

Por outro lado, a pesquisa conclusiva é caracterizada por estar voltada para a solução de problemas ou avaliação de alternativas de cursos de ação, além de ser bem estruturada, possuir objetivos bem definidos e procedimentos formais (MATTAR, 1999).

A seguir, os principais aspectos da metodologia utilizada na realização desta pesquisa serão comentados, estando organizados nos seguintes tópicos: o estudo de caso, incluindo os conceitos desse método e da pesquisa-ação, a descrição do caso escolhido e o escopo da pesquisa; as variáveis e indicadores da pesquisa; as técnicas e instrumentos de coleta de dados; o plano de amostragem; o modelo da pesquisa.

\subsection{O Estudo de Caso}

Primeiramente, neste capítulo, são apresentados alguns conceitos importantes sobre a utilização da metodologia de estudo de caso e da pesquisa-ação, estratégias utilizadas neste estudo. Em seguida, o caso escolhido para esta pesquisa é descrito.

\subsubsection{A Estratégia do Estudo de Caso e a Pesquisa-ação}

A estratégia do estudo de caso é escolhida, dentre outros aspectos, "quando o pesquisador tem pouco controle sobre os eventos e quando o foco se encontra em fenômenos contemporâneos inseridos em algum contexto da vida real”' (YIN, 2001, p. 19).

O caso a ser estudado precisa ser um sistema específico, com limites bem definidos, sendo esses fatores críticos para seu entendimento (STAKE,1994). O pesquisador pode decidir estudar vários casos simultaneamente, mesmo assim, no momento em que é buscada a compreensão da complexidade de um caso, existe uma concentração da investigação nesse único caso.

É importante lembrar que o propósito do estudo de caso não é representar a população e sim representar o caso em questão (STAKE, 1994; SCANDURA e WILLIAMS, 2000). Da 
mesma forma que em outros métodos qualitativos, os resultados não são necessariamente representativos da população, não possibilitando generalizações. Além disso, existe uma grande ambigüidade nos resultados, resultante da característica básica dos métodos qualitativos que é a flexibilidade do entrevistador direcionar as questões (AAKER e DAY, 1990).

A estratégia do estudo de caso busca a compreensão tanto do que é comum quanto do que é particular sobre o caso estudado (STAKE, 1994). Dessa forma, é comum levantar informações sobre: natureza do caso; fontes históricas; instalações físicas; contexto, incluindo econômico, político e legal; outros casos relacionados; sobre as pessoas através das quais o caso poderá ser compreendido.

A qualidade do estudo de caso é uma questão importante a ser considerada. Atendendo a essa preocupação, YIN (2001) apresenta os quatro testes mais utilizados em projetos de pesquisas sociais empíricas, recomenda táticas do método de estudo de caso e detalha a fase da pesquisa em que cada tática deve ser usada (Quadro 13).

\section{Quadro 13 - Táticas do estudo de caso para quatro testes de projeto}

\begin{tabular}{|l|l|l|}
\hline \multirow{1}{*}{\multicolumn{1}{|c|}{ TESTE }} & \multicolumn{1}{|c|}{ TÁTICA DO ESTUDO DE CASO } & $\begin{array}{l}\text { FASE DA PESQUISA NA } \\
\text { QUAL A TÁTICA DEVE } \\
\text { SER APLICADA }\end{array}$ \\
\hline \multirow{2}{*}{$\begin{array}{l}\text { Validade do } \\
\text { constructo }\end{array}$} & Utiliza fontes múltiplas de evidências & Coleta de dados \\
\cline { 2 - 3 } & Estabelece encadeamento de evidências & Coleta de dados \\
\cline { 2 - 3 } & $\begin{array}{l}\text { O rascunho do relatório estudo de caso é } \\
\text { revisado por informantes-chave }\end{array}$ & Composição \\
\hline $\begin{array}{l}\text { Validade } \\
\text { interna }\end{array}$ & Faz adequação ao padrão & Análise de dados \\
\cline { 2 - 3 } & Faz construção da explanação & Análise de dados \\
\cline { 2 - 3 } $\begin{array}{l}\text { Validade } \\
\text { externa }\end{array}$ & $\begin{array}{l}\text { Utiliza lógica de replicação em estudos } \\
\text { de casos múltiplos }\end{array}$ & Projeto de pesquisa \\
\hline Confiabilidade & Utiliza protocolo de estudo de caso & Coleta de dados \\
\cline { 2 - 3 } & $\begin{array}{l}\text { Desenvolve banco de dados para o } \\
\text { estudo de caso }\end{array}$ & Coleta de dados \\
\hline
\end{tabular}

Fonte: YIN (2001, p. 55).

A seguir, o conceito de pesquisa-ação é comentado, tendo em vista que, durante a realização deste trabalho, a pesquisadora participou das ações de ensino como monitora, ministrando algumas aulas e construindo e acompanhando as atividades de e-learning do caso estudado. 
De acordo com THIOLLENT, "na pesquisa-ação os pesquisadores desempenham um papel ativo no equacionamento dos problemas encontrados, no acompanhamento e na avaliação das ações desencadeadas em função dos problemas” (2002, p. 15).

A área educacional possui tradição na utilização de métodos como o da pesquisa-ação. Uma das justificativas "consiste na constatação de uma desilusão para com a metodologia convencional, cujos resultados, apesar de sua aparente precisão, estão muito afastados dos problemas urgentes da situação atual da educação" (THIOLLENT, 2002, p. 74). Dessa forma, a partir da utilização desse método, "os pesquisadores em educação estariam em condição de produzir informações e conhecimentos de uso mais efetivo, inclusive a nível pedagógico" (THIOLLENT, 2002, p. 75).

\subsubsection{A Descrição do Caso Escolhido}

Para realização desta pesquisa, foi escolhido o caso da disciplina Administração de Recursos Humanos I, parte integrante do curso de graduação em administração da Faculdade de Economia, Administração e Contabilidade da Universidade de São Paulo (FEA/USP).

O Departamento de Administração da FEA/USP tem como missão "contribuir para o avanço do conhecimento em Administração, formando administradores de alta competência e socialmente responsáveis" (FEA, 2003). Para tanto, possui 76 professores, alocados em sete áreas: Administração Geral; Finanças; Métodos Quantitativos e Informática; Marketing; Recursos Humanos; Produção e Operações; Política de Negócios e Economia de Empresas. Também conta com vários núcleos específicos de estudo e com o apoio da FIA - Fundação do Instituto de Administração, instituição conveniada com a FEA/USP. Entre os cursos realizados estão os de graduação, pós-graduação e especialização.

O curso de graduação em Administração da FEA/USP oferecido no período diurno tem duração de 4 anos (mínimo de 8 semestres e máximo de 14 semestres), enquanto, no período noturno, a duração é de 5 anos. De acordo com estatísticas divulgadas pela FUVEST (Fundação Universitária para o Vestibular), para 2003, foram abertas 210 vagas no curso de graduação em Administração da FEA/USP/SP, sendo que 5.970 estudantes com segundo grau completo se inscreveram no processo seletivo, resultando em um total de 28,4 candidatos por vaga. 
O curso de graduação em Administração vem obtendo, desde 1996, conceito "A" na avaliação realizada pelo MEC através do Exame Nacional de Cursos, o Provão (EXAME NACIONAL DE CURSOS, 2002).

A disciplina Administração de RH I, foco deste estudo, foi ministrada no segundo semestre de 2002, para alunos do segundo ano do curso de administração, período diurno, pela Prof ${ }^{\mathrm{a}}$. Dr ${ }^{\mathrm{a}}$. Maria Tereza Leme Fleury e pela Prof ${ }^{\mathrm{a}}$. Dr ${ }^{\mathrm{a}}$. Ana Cristina Limongi França. A disciplina contou com o apoio de duas monitoras (Andréa Kanikadan e Liliana Vasconcellos Jacobsohn), uma tendo auxiliado mais no controle e feedback das atividades realizadas em classe e outra, a pesquisadora deste estudo, focalizou sua atuação na implementação e acompanhamento das atividades de $e$-learning.

Os objetivos propostos na disciplina Administração de RH I em relação ao desenvolvimento dos alunos foram:

- Assimilar os principais pressupostos teóricos que fundamentam a definição de políticas e práticas de Administração de Recursos Humanos nas organizações;

- Conhecer as principais atividades e procedimentos dos vários subsistemas da Administração de RH e os impactos de sua operacionalização em diferentes instâncias organizacionais;

- Familiarizar-se com o processo de formulação de políticas de gestão de RH, identificando seus elementos de implementação e avaliação;

- Implementar a metodologia e-learning através da utilização intensa de um ambiente virtual na Internet (WebCT), consolidando o auto-aprendizado contínuo;

- Criar uma comunidade de discussão virtual a partir de conteúdos específicos de forma a estimular a discussão crítica e a avaliação sistemática do aprendizado.

As atividades realizadas nessa disciplina podem ser agrupadas em presenciais e de ensino a distância através da Internet (e-learning), utilizando um modelo essencialmente presencial (90\% das aulas foram presenciais) com atividades de e-learning de forma complementar:

- $\quad$ Atividades presenciais: exposição dialogada; exercícios em classe; discussão de filmes e casos; simulações; desenvolvimento de trabalho de pesquisa em campo; seminário; 
- Atividades de e-learning: auto-estudo; testes auto-corrigidos (questões de múltipla escolha com resposta automática) sobre os textos de leitura; pesquisa na Internet; discussões através do Fórum e Chat.

Algumas das atividades de e-learning foram organizadas em uma Aula Virtual, em substituição a uma aula presencial, e que consistiu de 1 hora e 30 minutos de atividades a distância, organizadas da seguinte forma:

- Parte 1 - Auto-estudo (30 minutos): absorção do novo conteúdo através de vídeo, leitura de texto e/ou exercícios com protocolo de resposta auto-corrigido;

- Parte 2 - Discussão (30 minutos): discussão da questão proposta no Fórum e pesquisa de informações adicionais sobre o assunto;

- Parte 3 - Fechamento (30 minutos): Chat realizado no horário da aula presencial, para fechamento da discussão. Foi cobrada presença da mesma forma que na aula presencial.

No total foram realizadas 3 aulas virtuais, estando as atividades de cada uma dessas aulas detalhadas no Apêndice A. O Quadro 14 apresenta um resumo do total de atividades de e-learning realizadas durante o curso.

Quadro 14 - Atividades de e-Learning Realizadas na Disciplina Administração de RH1

\begin{tabular}{|l|l|}
\hline Conteúdo & 16 textos para leitura complementar sobre os diversos temas da \\
disponibilizado & disciplina \\
& Maior parte das transparências utilizadas em classe (14 conjuntos) \\
& 1 Vídeo sobre Educação Corporativa \\
& 2 cursos de e-learning utilizando slides animados e voz, sobre Gestão de \\
& Competências e Qualidade de Vida no Trabalho, além de exercícios e \\
& textos complementares (opcionais). \\
\hline Exercícios e & 4 Testes auto-corrigidos \\
discussões & 2 exercícios específicos de pesquisa na Internet (utilização do banco de \\
propostos & dados ProQuest e atividade WebQuest) \\
& Fórum disponível durante todo o semestre \\
& Realização de 3 Chats \\
\hline
\end{tabular}

Dentre as atividades de e-learning realizadas, foi proposta uma WebQuest sobre Qualidade de Vida no Trabalho, na qual a tarefa dos alunos era sugerir um Programa de Qualidade de Vida para a empresa Music Television - MTV (as instruções da atividade encontram-se no Apêndice B). 
A avaliação do nível de aproveitamento na disciplina foi realizada da seguinte forma:

- $1^{\mathrm{a}}$ prova $-25 \%$

- $2^{\text {a }}$ prova $-25 \%$

- Trabalho final - 25\% (12,5\% projeto do trabalho e $12,5 \%$ apresentação final)

- Participação (atividades a distância e presenciais) - 25\%

Para implementação das atividades de e-learning foi utilizado o software WebCT, disponível para todos os professores e alunos da USP. O WebCT foi desenvolvido por Murray Goldberg, da University of British Columbia, em 1997, com o objetivo de criar "uma coleção inovativa de ferramentas baseadas na Web que facilitassem aos instrutores criar e fundir conteúdos e que fosse simples para os alunos usarem" (HUTCHINS, 2001). Dados do site da empresa (WEBCT, 2001) apontam que, em julho de 2000, o WebCT já tinha mais de 6,7 milhões de estudantes espalhados por cerca de 147.000 Faculdades e Universidades em 57 países ao redor do mundo.

Utilizando-se da Internet, o WebCT proporciona que os estudantes interajam com o material do curso e os instrutores criem ou modifiquem cursos já existentes (KHAN, 1997). Conforme HUTCHINS (2001) e WEBCT (2001), a interface que esse recurso proporciona é bastante simples, tanto para o instrutor construir o curso (organização do conteúdo, formato e design) e gerenciá-lo (utilizando-se de ferramentas como o administrador, controle de acesso, grade, gráficos, sistema de conferência, área para Chat, e-mail, apresentações, auto-avaliação, "quizzes" online, glossário, acompanhamento do progresso do aluno e busca) como para os alunos aprenderem e interagirem (por exemplo, enviar e-mails para o grupo, participar de Chats privados ou abertos, revisar o trabalho dos colegas, iniciar e participar de fóruns de discussão).

A Figura 12, a seguir, mostra a tela inicial do ambiente WebCT construído para a disciplina Administração de RH I. 
Figura 12 - Página Inicial do Ambiente da Disciplina na Internet

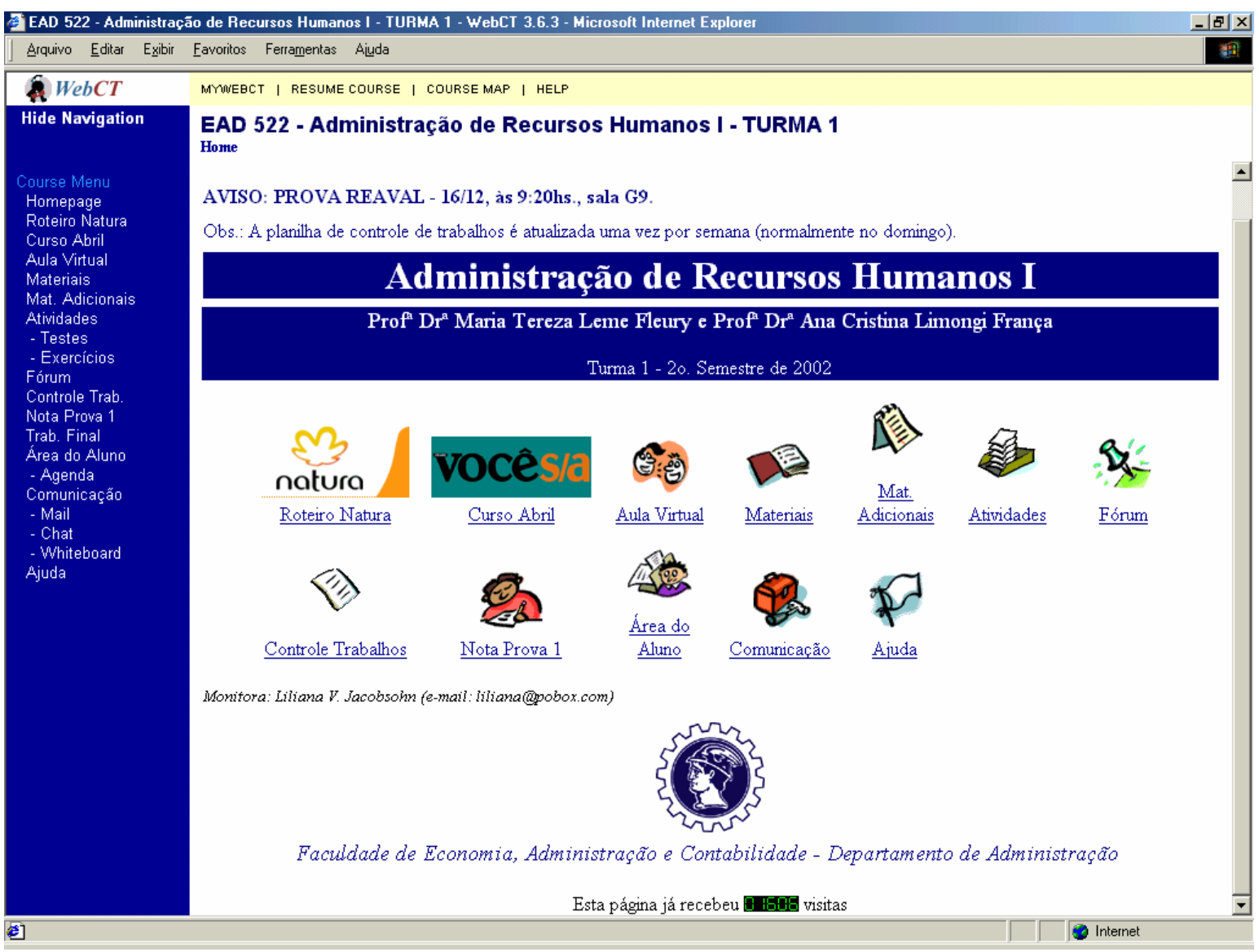

Com base nas recomendações de uma experiência realizada com alunos de pósgraduação, descrita por JACOBSOHN et al. (2002), no início do semestre foi realizada uma aula presencial no laboratório de informática, para que os alunos acessassem, pela primeira vez, o software WebCT e praticassem a utilização dos recursos e ferramentas disponíveis no sistema.

\subsubsection{Escopo da Pesquisa}

É importante esclarecer alguns aspectos que não fazem parte do objetivo deste trabalho:

- Apresentar de forma detalhada a discussão sobre a formação do administrador, sobre as teorias de aprendizagem, incluindo estilo de aprendizagem e tipos psicológicos;

- Comprovar a validade e confiabilidade dos instrumentos de coleta de dados utilizados; 
- Analisar a gestão do e-learning como um todo, visto que o foco está no planejamento das atividades, deixando os demais aspectos para pesquisas futuras;

- Discutir a questão do e-learning do ponto de vista da instituição;

- Analisar, no caso estudado, todas as competências que o e-learning pode ajudar a desenvolver, considerando que foram escolhidas apenas cinco competências em função das atividades realizadas;

- Analisar com detalhe os aspectos tecnológicos envolvidos.

\subsection{As Variáveis da Pesquisa}

A partir da revisão bibliográfica foram definidos variáveis e indicadores para cada uma das três dimensões da pesquisa, tendo em vista os objetivos estabelecidos (Quadro 15).

Quadro 15 - Variáveis e Indicadores da Pesquisa por Dimensão

\begin{tabular}{|c|c|c|}
\hline DIMENSÃO & VARIÁVEL & INDICADOR \\
\hline \multirow[t]{3}{*}{$\begin{array}{l}\text { Competências } \\
\text { do } \\
\text { administrador }\end{array}$} & $\begin{array}{l}\text { Grau de contribuição das atividades } \\
\text { de } e \text {-learning no desenvolvimento de } \\
\text { competências técnicas }\end{array}$ & $\begin{array}{l}\text { Contribuição de cada atividade de } \\
\text { e-learning para o aprendizado: } \\
\text { - Teste auto-corrigido } \\
\text { - WebQuest } \\
\text { - Fórum } \\
\text { - Chat } \\
\text { Contribuição geral do e-learning } \\
\text { para o aprendizado }\end{array}$ \\
\hline & $\begin{array}{l}\text { Grau de contribuição do e-learning } \\
\text { no desenvolvimento de } \\
\text { competências de aprendizagem }\end{array}$ & $\begin{array}{l}\text { Contribuição do e-learning no } \\
\text { desenvolvimento das } \\
\text { competências: } \\
\text { - Auto-aprendizagem } \\
\text { - Pesquisa na Internet }\end{array}$ \\
\hline & $\begin{array}{l}\text { Grau de contribuição do e-learning } \\
\text { no desenvolvimento de } \\
\text { competências sociais }\end{array}$ & $\begin{array}{l}\text { Contribuição do e-learning no } \\
\text { desenvolvimento das } \\
\text { competências: } \\
\text { - Comunicação em ambientes } \\
\text { virtuais } \\
\text { - Participação em discussões } \\
\text { - Formação de comunidades } \\
\text { virtuais }\end{array}$ \\
\hline
\end{tabular}


Quadro 15 - Variáveis e Indicadores da Pesquisa por Dimensão (continuação)

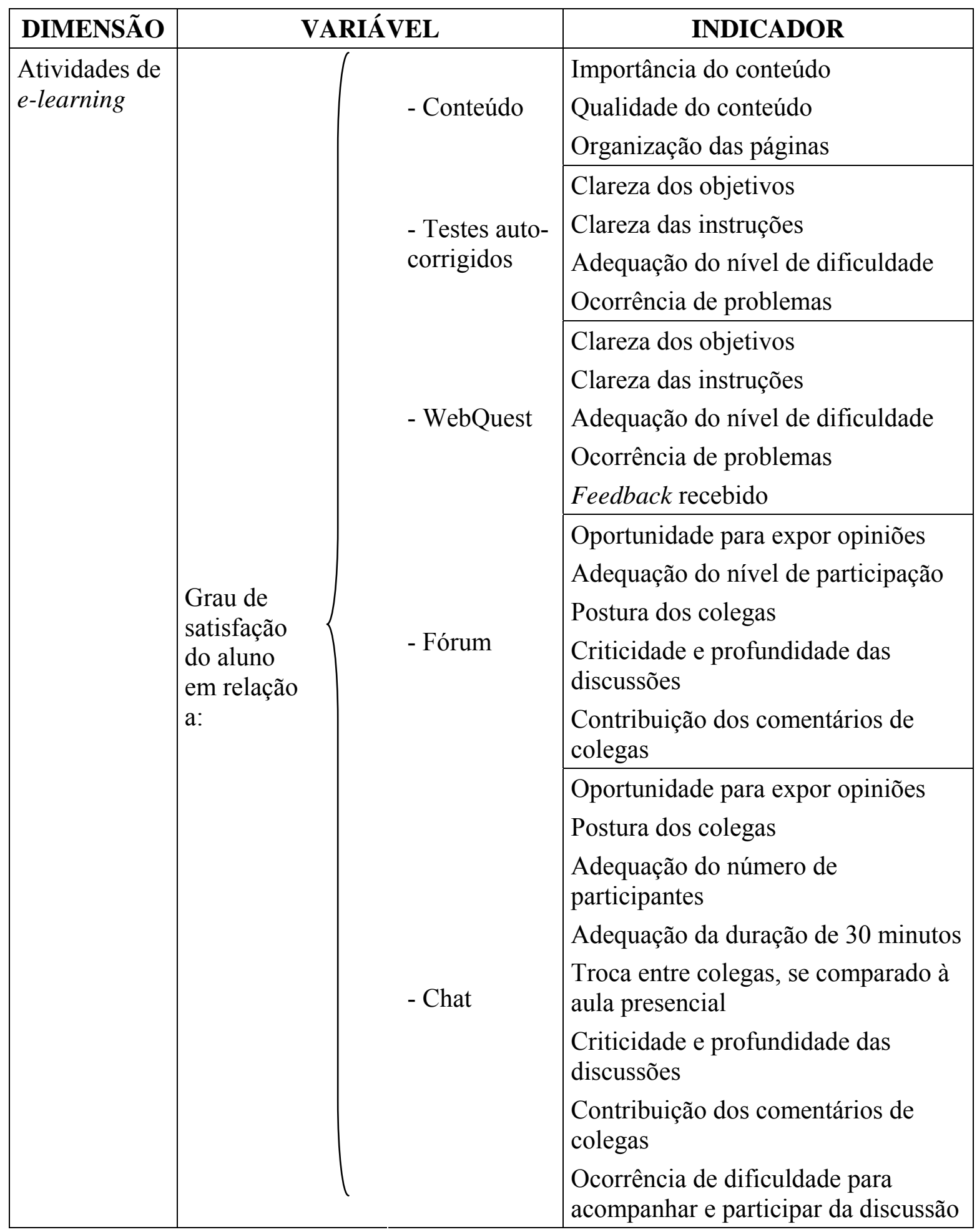


Quadro 15 - Variáveis e Indicadores da Pesquisa por Dimensão (continuação)

\begin{tabular}{|l|l|l|}
\hline DIMENSÃO & \multicolumn{1}{|c|}{ VARIÁVEL } & \multicolumn{1}{c|}{ INDICADOR } \\
\hline $\begin{array}{l}\text { Atividades de } \\
\text { e-learning } \\
\text { (continuação) }\end{array}$ & $\begin{array}{l}\text { Grau de satisfação geral do aluno } \\
\text { em relação ao e-learning }\end{array}$ & $\begin{array}{l}\text { Atendimento às expectativas } \\
\text { Aumento do interesse em Gestão de } \\
\text { Pessoas } \\
\text { Adequação da substituição da aula } \\
\text { presencial pela virtual } \\
\text { Adequação da integração entre } \\
\text { atividades online e presenciais } \\
\text { Interesse em cursar outra disciplina } \\
\text { com atividades de e-learning }\end{array}$ \\
\hline $\begin{array}{l}\text { Estilo de } \\
\text { aprendizagem }\end{array}$ & $\begin{array}{l}\text { Preferências do aluno em relação } \\
\text { ao processo de aprendizagem } \\
\text { com base na teoria de Tipos } \\
\text { Psicológicos (CASADO, 1998) }\end{array}$ & $\begin{array}{l}\text { Disposição a: } \\
\text { Extroversão/ Introversão } \\
\text { Sensação/ Intuição } \\
\text { Pensamento/ Sentimento } \\
\text { Percepção/ Julgamento }\end{array}$ \\
\hline
\end{tabular}

A partir da pesquisa bibliográfica, também foram identificadas variáveis intervenientes com potencial de influenciar as dimensões pesquisadas (Quadro 16).

Quadro 16 - Variáveis Intervenientes e seus Indicadores

\begin{tabular}{|l|l|}
\hline \multicolumn{1}{|c|}{ VARIÁVEL } & \multicolumn{1}{c|}{ INDICADOR } \\
\hline $\begin{array}{l}\text { Características do } \\
\text { Perfil do Aluno }\end{array}$ & $\begin{array}{l}\text { Interesse pelo tema (Gestão de Pessoas) } \\
\text { Avaliação quanto ao nível de motivação para realizar um bom } \\
\text { trabalho } \\
\text { Adequação da carga de trabalho proposta } \\
\text { Incidência de dificuldades relacionadas à falta de tempo } \\
\text { Impressão sobre e-learning } \\
\text { Nível de satisfação com experiências anteriores de e-learning } \\
\text { Freqüência de acesso à Internet } \\
\text { Familiaridade com informática/Internet }\end{array}$ \\
\hline $\begin{array}{l}\text { Grau de satisfação } \\
\text { em relação aos } \\
\text { aspectos } \\
\text { tecnológicos }\end{array}$ & $\begin{array}{l}\text { Facilidade de acesso ao site do WebCT } \\
\text { Adequação do tempo de resposta do sistema (WebCT) } \\
\text { Facilidade de navegação nas telas do WebCT } \\
\text { Facilidade para utilização das ferramentas do WebCT } \\
\text { Ocorrência de dificuldades relacionadas à insuficiência dos } \\
\text { recursos tecnológicos disponíveis }\end{array}$ \\
\hline
\end{tabular}


Quadro 16 - Variáveis Intervenientes e seus Indicadores (continuação)

\begin{tabular}{|l|l|}
\hline \multicolumn{1}{|c|}{ VARIÁVEL } & \multicolumn{1}{c|}{ INDICADOR } \\
\hline $\begin{array}{l}\text { Nível de } \\
\text { aproveitamento do } \\
\text { curso }\end{array}$ & $\begin{array}{l}\text { Número de acessos à Homepage, atividades, ferramentas de } \\
\text { comunicação e materiais (No de Hits) } \\
\text { Número de mensagens lidas e enviadas ao Fórum (nível de } \\
\text { participação no Fórum) } \\
\text { Nível de participação online } \\
\text { Nota nos testes auto-corrigidos } \\
\text { Nota das provas da disciplina } \\
\text { Nota no trabalho final }\end{array}$ \\
$\begin{array}{l}\text { Nota de participação nas atividades presenciais e online } \\
\text { Nota final da disciplina } \\
\text { Freqüência nas aulas presenciais }\end{array}$ \\
\hline $\begin{array}{l}\text { Grau de } \\
\text { satisfação do } \\
\text { professor com a } \\
\text { utilização do } e- \\
\text { learning }\end{array}$ & $\begin{array}{l}\text { Opinião dos professores sobre a utilização do e-learning: } \\
\text { contribuições e desafios }\end{array}$ \\
\hline
\end{tabular}

\subsection{Necessidade e Fontes de Dados}

Os dados podem ser caracterizados em dois tipos distintos (MATTAR, 1999:134):

- Dados primários: aqueles que não foram coletados antes, estando ainda com os pesquisados. Fontes: pessoas, pessoas com informações sobre o pesquisado e situações similares;

- Dados secundários: dados já coletados, tabulados, ordenados e até analisados para outros propósitos. Fontes: publicações, governos, instituições não governamentais e prestadores de serviços.

O Quadro 17, apresentado a seguir, detalha os dados necessários para a realização desta pesquisa, sua classificação e as fontes onde foram obtidos. 
Quadro 17 - Necessidade e fontes de dados

\begin{tabular}{|l|l|l|}
\hline \multicolumn{1}{|c|}{ NECESSIDADE } & $\begin{array}{c}\text { TIPO DE } \\
\text { DADO }\end{array}$ & \multicolumn{1}{|c|}{ FONTE DE DADO } \\
\hline $\begin{array}{l}\text { Fundamentação teórica sobre Formação do } \\
\text { Administrador, Aprendizagem e e-Learning }\end{array}$ & Secundário & $\begin{array}{l}\text { Publicações, pesquisas } \\
\text { realizadas e sites da } \\
\text { Internet }\end{array}$ \\
\hline $\begin{array}{l}\text { Grau de contribuição do e-learning no } \\
\text { desenvolvimento de competências } \\
\text { Grau de satisfação em relação às atividades de } \\
\text { e-learning realizadas } \\
\text { Preferências do aluno em relação ao processo } \\
\text { de aprendizagem (estilo de aprendizagem) } \\
\text { Perfil do aluno* } \\
\text { Opinião sobre aspectos tecnológicos* }\end{array}$ & Primário & $\begin{array}{l}\text { Alunos da disciplina } \\
\text { pesquisada }\end{array}$ \\
\hline $\begin{array}{l}\text { Grau de satisfação do professor com a } \\
\text { utilização do } \text {-learning* }\end{array}$ & Primário & $\begin{array}{l}\text { Professores da disciplina } \\
\text { pesquisada }\end{array}$ \\
\hline Aproveitamento do curso* & Primário & $\begin{array}{l}\text { Relatórios de } \\
\text { acompanhamento }\end{array}$ \\
\hline
\end{tabular}

(*) Variáveis intervenientes

\subsection{Técnicas e Instrumentos de Coleta dos Dados}

De acordo com MATTAR (1999, p. 159-160), existem dois métodos básicos para coleta de dados primários:

- Comunicação: questionamento verbal ou escrito dos respondentes para obtenção da informação desejada;

- Observação: registro de comportamento, fatos e ações de interesse para a pesquisa.

Nesta pesquisa o levantamento de dados primários foi realizado através da comunicação. Essa escolha pode ser justificada pelas vantagens do método: versatilidade, rapidez, menor custo e possibilidade de obter a grande maioria de tipos de dados (MATTAR, 1999).

As formas de aplicação do método de comunicação são (MATTAR, 1999, p. 160):

- Entrevista: pessoal (individual ou em grupo) ou por telefone; 
- Questionário auto-preenchido: pessoal, correio/ fax, jornais/ revistas, acompanhando um produto, e-mail ou publicação em página da Internet.

Os critérios para decidir sobre a utilização do instrumento de coleta de dados são muitos, como por exemplo: o tipo de pesquisa (exploratória ou conclusiva), o tipo de respondente (nível educacional e social), o assunto da pesquisa, a disponibilidade de meios para administrar a pesquisa, incluindo a qualidade do funcionamento e o acesso ao público pesquisado e o tipo de análise e interpretação pretendidas (MATTAR, 1999).

Nesta pesquisa, foram utilizados três questionários auto-preenchidos, além de entrevistas e documentos. O Quadro 18, a seguir, apresenta os instrumentos utilizados para levantar cada uma das informações necessárias.

Quadro 18 - Necessidade de Dados Primários e Técnica/Instrumentos de Coleta

\begin{tabular}{|c|c|}
\hline NECESSIDADE & TÉCNICA / INSTRUMENTO DE COLETA \\
\hline $\begin{array}{l}\text { Grau de contribuição do e-learning no } \\
\text { desenvolvimento de competências }\end{array}$ & \multirow[t]{3}{*}{ Questionário de Avaliação (Apêndice C) } \\
\hline $\begin{array}{l}\text { Grau de satisfação em relação às } \\
\text { atividades de } e \text {-learning realizadas }\end{array}$ & \\
\hline Opinião sobre aspectos tecnológicos* & \\
\hline $\begin{array}{l}\text { Preferências do aluno em relação ao } \\
\text { processo de aprendizagem (estilo de } \\
\text { aprendizagem) }\end{array}$ & $\begin{array}{l}\text { Inventário Brasileiro para Diagnóstico das } \\
\text { Diferenças Individuais }\end{array}$ \\
\hline Perfil do aluno* & Questionário de Perfil (Apêndice D) \\
\hline $\begin{array}{l}\text { Grau de satisfação do professor com a } \\
\text { utilização do e-learning* }\end{array}$ & Entrevista individual \\
\hline Aproveitamento do curso* & Relatórios de acompanhamento da disciplina \\
\hline
\end{tabular}

(*) Variáveis intervenientes.

Os tópicos seguintes apresentam com maior detalhe os instrumentos e técnicas da coleta de dados primários desta pesquisa: questionários auto-preenchidos e entrevista individual, incluindo alguns conceitos e a forma de utilização de cada um. 


\subsubsection{Os Questionários Auto-preenchidos}

\section{Os Questionários de Perfil e de Avaliação}

MATTAR apresenta o conceito do processo de medição, realizado através da aplicação do instrumento de coleta de dados: "O processo de medição consiste em associar números a um objeto, que, segundo uma regra estabelecida, passam a representar as quantidades de suas características ou atributos" (1999, p. 194).

Para realizar a medição, são necessários objetos, uma propriedade a ser medida e um instrumento. A construção do instrumento de coleta de dados inclui a definição da escala que será utilizada. A escala nominal possibilita "classificar um objeto, pessoa ou alguma característica, por meio de números ou outros símbolos" (MARTINS, 2001, p. 26). A escala ordinal é utilizada para ordenar, através da comparação, pessoas, objetos ou fatos, em relação à determinada característica. A grande diferença da escala ordinal, se comparada à intervalar, está relacionada à impossibilidade de ser definido o tamanho do intervalo entre o elemento colocado em primeiro lugar e o colocado em segundo na ordenação. Dessa forma, a escala intervalar é aquela em que os intervalos entre os números demonstram a "posição e quanto que as pessoas, objetos ou fatos estão distantes entre si, em relação a determinada característica” (MATTAR, 1999, p. 197).

O Questionário de Perfil utiliza uma escala nominal e questões abertas, com o objetivo de levantar dados pessoais, perfil de acesso à Internet, infra-estrutura tecnológica utilizada e experiências anteriores com e-learning.

O Questionário de Avaliação utilizado para levantamento da opinião dos alunos sobre a contribuição do e-learning no desenvolvimento de competências, o grau de satisfação em relação às atividades de e-learning e os aspectos tecnológicos foi construído com uma escala ordinal, com notas de zero (péssimo) a dez (excelente), além de questões abertas e espaços para inclusão de comentários.

Embora não tenha sido possível realizar um pré-teste dos questionários, por limitações de cronograma, o Questionário de Avaliação já tinha sido aplicado em uma disciplina de pósgraduação (JACOBSOHN et al., 2002), com formato muito semelhante, o que possibilitou seu aprimoramento para utilização na presente pesquisa. 


\section{Instrumento para Análise do Estilo de Aprendizagem}

Para análise do estilo de aprendizagem dos alunos, foi selecionado o Inventário Brasileiro para Diagnóstico das Diferenças Individuais, desenvolvido pela Prof ${ }^{\mathrm{a}}$. Dr ${ }^{\mathrm{a}}$. Tânia CASADO (1998). A justificativa dessa escolha é apresentada a seguir.

Três critérios foram considerados na seleção do instrumento utilizado nesta pesquisa para identificar o estilo de aprendizagem dos alunos:

1. Acesso ao instrumento;

2. Ampla utilização em pesquisas anteriores realizadas;

3. Idioma do instrumento;

4. Validade do instrumento.

Através da revisão bibliográfica foi possível ter acesso aos seguintes instrumentos relacionados a estilos de aprendizagem:

- Índice de Estilo de Aprendizagem, desenvolvido por FELDER e SALOMAN;

- Questionário de Estilo de Aprendizagem, proposto por HONEY \& MUMFORD;

- Inventário de Estilo de Aprendizagem, proposto por David KOLB;

- Inventário Brasileiro para Diagnóstico de Diferenças Individuais, desenvolvido por Tânia CASADO.

O instrumento proposto por FELDER \& SALOMAN foi descartado, pois não possui uma ampla utilização em pesquisas anteriores, considerando que foi criado recentemente como uma alternativa ao Inventário de KOLB. Além disso, uma pesquisa de mestrado defendida recentemente na Universidade Federal de Santa Catarina verificou que a validade desse instrumento está comprometida (W. M. G. LOPES, 2002). O questionário de HONEY \& MUMFORD também foi descartado, considerando que estava disponível apenas em inglês.

Sendo assim, os dois instrumentos que atendiam aos três primeiros critérios são: o Inventário de Estilo de Aprendizagem, proposto por KOLB, utilizado em mais de 150 pesquisas (KARUPPAN, 2001) e o instrumento desenvolvido por CASADO, que tem sido amplamente aplicado em turmas de alunos de graduação da FEA/USP e em turmas de cursos para executivos. 
Por outro lado, enquanto o instrumento desenvolvido por KOLB foi traduzido para o português, o Inventário Brasileiro para Diagnóstico das Diferenças Individuais foi "criado em Português falado no Brasil, extinguindo problemas decorrentes de tradução, de expressões idiomáticas e de aspectos culturais diversos da população alvo" (CASADO, 1998, p. 84).

Além disso, a validade do Inventário de Estilo de Aprendizagem, proposto por KOLB, recebeu algumas críticas quanto a sua validade (BOSTROM, OLFMAN e SEIN, 1993), apesar de os autores terem concluído que possíveis imperfeições existentes nesse inventário não afetaram de forma significativa a operacionalização dos estilos de aprendizagem nas pesquisas realizadas.

Assim, para esta pesquisa, optou-se pela aplicação do Inventário Brasileiro para Diagnóstico das Diferenças Individuais, tendo em vista que sua validade foi comprovada na tese de doutorado defendida por CASADO, que concluiu que o instrumento "demonstrou validade de conteúdo, tendo capacidade para medir o que se propõe medir” (1998, p. 149).

O Inventário Brasileiro para Diagnóstico das Diferenças Individuais é constituído por 150 questões com no mínimo duas alternativas de resposta cada, abordando temas e situações cotidianos. "Através das respostas, o sujeito expressa suas preferências entre aspectos opostos" (CASADO, 1994, p. 2). O instrumento "revela quatro dimensões, com dois pólos contrastantes e complementares cada uma, resultando na determinação de dezesseis tipos psicológicos" (CASADO, 1994, p. 2). Como resultado de sua aplicação, as preferências dos respondentes são identificadas através da determinação do tipo psicológico de cada um.

\section{$\underline{\text { A Forma de Aplicação dos Questionários }}$}

MATTAR (1999, p. 174) discute as formas de aplicação do questionário (entrevista pessoal, entrevista por telefone e correio) em função de características como custo, tempo para aplicação, controle amostral, uniformidade da mensuração, nível educacional exigido dos respondentes, tamanho da amostra, entre outras características.

Assim, tendo em vista o tamanho da amostra, o contexto do caso estudado e os recursos disponíveis, optou-se por aplicar os questionários durante a aula presencial, possibilitando um maior número de respostas. Além disso, o preenchimento dos questionários foi considerado como uma das atividades da disciplina, valendo nota de participação. 
No final do semestre foi enviado um e-mail para os alunos que não tinham preenchido todos os questionários, solicitando a colaboração através do preenchimento do documento em formato eletrônico e reenvio através do próprio e-mail.

No caso específico do Inventário Brasileiro para Diagnóstico das Diferenças Individuais, a Prof ${ }^{\mathrm{a}}$. Dr ${ }^{\mathrm{a}}$. Tânia Casado aplicou, pessoalmente, o questionário de acordo o procedimento normalmente utilizado, impossibilitando a opção de preenchimento em formato eletrônico no caso dos alunos que não estavam presentes na aula em questão.

\subsubsection{A Entrevista Individual}

As vantagens e desvantagens da entrevista individual em profundidade propostas por GORDON e LANGMAID (1988, p. 15-16, tradução da autora) são apresentadas no Quadro 19.

\section{Quadro 19 - Vantagens e Desvantagens da Entrevista Individual em Profundidade}

\begin{tabular}{|c|c|}
\hline VANTAGENS & DESVANTAGENS \\
\hline $\begin{array}{l}\text { Informações longitudinais podem ser obtidas de um respondente } \\
\text { de cada vez (exemplo: processo de compras); } \\
\text { A opinião da maioria e da minoria pode ser notada independente } \\
\text { do processo de grupo; } \\
\text { Um senso de perspectiva é possível, particularmente quando são } \\
\text { realizadas várias entrevistas; } \\
\text { Assuntos muito íntimos e pessoais podem ser discutidos; } \\
\text { Não ocorre pressão de colegas de grupo; } \\
\text { As habilidades do entrevistador podem superar a tendência de } \\
\text { expressar atitudes e comportamentos socialmente aceitos; } \\
\text { Dificuldades no recrutamento de participantes podem ser } \\
\text { transpostas; } \\
\text { A amostra pode ser segmentada e dividida de forma a cobrir mais } \\
\text { células do que normalmente é possível em entrevistas em grupo. }\end{array}$ & $\begin{array}{l}\text { Consome muito tempo, } \\
\text { tanto na condução da } \\
\text { entrevista quanto na } \\
\text { análise das fitas } \\
\text { gravadas; } \\
\text { O custo é alto; } \\
\text { Existe uma tendência de } \\
\text { as pessoas pensarem } \\
\text { logo em quantos ao } \\
\text { invés de como, por que } \\
\text { e o que. }\end{array}$ \\
\hline
\end{tabular}

A entrevista pode ser classificada de acordo com seu grau de estruturação, conforme apresentado por FONTANA e FREY (1994:363) e por AAKER e DAY (1990, p. 163-164):

- Entrevista estruturada: o entrevistador faz uma série de perguntas pré-estabelecidas ao respondente, que possui limitação nas opções de respostas por categorias, resultando em pouca flexibilidade nas questões realizadas e nas respostas fornecidas. Este tipo de 
entrevista, normalmente, não é considerada como uma entrevista em profundidade, como ocorre nas outras duas classificações;

- Entrevista semi-estruturada: o entrevistador procura abordar uma lista específica de tópicos e subárea. As palavras exatas a serem utilizadas e o momento de questionar sobre cada tópico ficam a critério do entrevistador;

- Entrevista não estruturada: o respondente possui grande liberdade para responder dentro dos assuntos de interesse do entrevistador. Além disso, é estabelecida uma interação entre o entrevistador e o entrevistado, através da abertura existente para o entrevistador responder questões e da possibilidade de desvio do roteiro de acordo com os sentimentos do entrevistador.

A entrevista semi-estruturada foi utilizada para levantar a opinião das professoras que ministraram a disciplina Administração de RH I em relação utilização do e-learning, visando à complementação das análises realizadas em função da opinião dos alunos. $\mathrm{O}$ roteiro da entrevista encontra-se no Apêndice E.

\subsection{A População e a Amostra}

MATTAR (1999, p. 266) apresenta alguns dos conceitos importantes sobre população e amostra:

- "População de pesquisa é o agregado de todos os casos que se enquadram em um conjunto de especificações previamente estabelecidas";

- "Amostra é qualquer parte de uma população", selecionada segundo determinadas regras;

- "Amostragem é o processo de colher amostras de uma população".

A amostra pode ser definida conforme dois métodos diferentes (MATTAR 1999, p. 268):

- Amostragem probabilística: cada elemento da população tem uma chance conhecida e diferente de zero de ser selecionado para compor a amostra, não quer dizer que as probabilidades precisam ser iguais (amostra probabilística);

- Amostragem não probabilística: a seleção dos elementos da amostra depende do julgamento do pesquisador, não sendo possível determinar a probabilidade do elemento fazer parte da amostra (amostra não probabilística). 
É importante ressaltar que apenas a amostra probabilística possibilita generalização dos resultados para a população, que não é o caso da amostra utilizada nesta pesquisa.

Assim para a realização da pesquisa empírica, foi escolhida uma disciplina entre aquelas oferecidas no curso de graduação em Administração da FEA/USP, no segundo semestre de 2002, para análise da opinião dos alunos que integraram as turmas 1 e 2 do período diurno, totalizando 119 estudantes. A seguir, estão apresentadas as principais definições do plano de amostragem.

\subsubsection{População e Unidade de listagem}

A população pesquisada está definida a seguir, de acordo com os termos propostos por MATTAR (1999, p. 264):

- Elementos de pesquisa (unidade sobre a qual procura-se obter informações): alunos de graduação em Administração da FEA/USP;

- Unidade amostral (“elemento disponível [...] para seleção em algum estágio do processo de amostragem"): disciplinas do curso de graduação em Administração na FEA/USP;

- Abrangência geográfica: São Paulo/SP;

- Período de tempo: agosto a dezembro de 2002.

\subsubsection{Método de amostragem}

Os métodos de amostragem podem ser agrupados conforme o tipo de amostra, ou seja, amostra não probabilística ou probabilística.

Os métodos de amostragem não probabilística apresentados por MATTAR (1999, p. 271-275) são:

- Conveniência ou acidental: seleção de acordo com alguma conveniência do pesquisador;

- Intencional ou julgamento: escolha com base no julgamento ou estratégia definida pelo pesquisador que atenda aos objetivos da pesquisa;

- Quotas ou proporcional: tentativa de obter uma amostra similar à população conforme determinados aspectos; 
- Tráfego: seleção de acordo com a disponibilidade no local;

- Autogeradas: o pesquisador tem pouco conhecimento sobre a população e, ao localizar elementos da amostra, solicita indicações de conhecidos que também façam parte da população;

- Desproporcionais: seleção de elementos de forma desproporcional a características conhecidas na população.

Para a realização desta pesquisa, o método de amostragem utilizado para escolha do caso foi conveniência; a seleção foi realizada tendo em vista o tema da disciplina e a viabilidade de implementar as atividades de e-learning propostas.

\subsubsection{Composição dos Elementos da Pesquisa}

No total, 119 alunos cursaram a disciplina Administração de RH I, escolhida para esta pesquisa. O Quadro 20 apresenta o número de questionários válidos obtidos e o período de aplicação, considerando cada um dos instrumentos de coleta. A última linha do quadro contém o total de alunos que preencheram todos os questionários aplicados.

Quadro 20 - Número de Questionários Válidos para cada Instrumento

\begin{tabular}{|l|c|c|}
\hline \multicolumn{1}{|c|}{ INSTRUMENTO DE COLETA } & $\begin{array}{c}\text { No }^{\circ} \text { DE QUESTIONÁRIOS } \\
\text { VÁLIDOS }\end{array}$ & APLICAÇÃO \\
\hline Questionário de Perfil (Apêndice D) & 117 & Agosto/2002 \\
\hline Questionário de Avaliação (Apêndice C) & 83 & Outubro/2002 \\
\hline $\begin{array}{l}\text { Inventário Brasileiro para Diagnóstico das } \\
\text { Diferenças Individuais }\end{array}$ & 84 & Novembro/2002 \\
\hline $\begin{array}{l}\text { Total de alunos que preencheram todos } \\
\text { os questionários }\end{array}$ & $\mathbf{6 1}$ & - \\
\hline
\end{tabular}

Nesse contexto, com o objetivo de aproveitar ao máximo os dados disponíveis, algumas das análises apresentadas no capítulo de resultados se referem ao total de respondentes do questionário em questão; ou seja, ao analisar a freqüência de respostas do Questionário de Avaliação foram considerados os 83 respondentes. Por outro lado, ao analisar possíveis relações entre as variáveis obtidas a partir de diferentes questionários foi considerado o grupo de 61 respondentes. Também, os testes de hipótese foram realizados com a amostra de 61 alunos, que responderam todos os questionários, exceto na análise do 
desenvolvimento da auto-aprendizagem em relação ao desenvolvimento da competência técnica em que foram considerados os 83 respondentes (tópico 4.2.1).

No total, dos 392 questionários válidos (considerando os quatro instrumentos) 349 foram recebidos em papel, durante o curso, e 42 foram recebidos após o término das aulas em formato de arquivo, através de e-mail.

A seguir, são apresentados alguns aspectos sobre o grupo de alunos que respondeu ao Questionário de Perfil ( $\mathrm{n}=117)$, incluindo informações gerais, utilização da Internet, infraestrutura tecnológica disponível e experiência anterior com e-learning:

- A maioria dos alunos é do sexo masculino (62\%);

- A média de idade é 20 anos (desvio padrão igual a 1,2), variando entre 18 e 25, não incluindo a idade de 35 anos, valor que foge das dimensões esperadas - outlier (MARTINS, 2001:59);

- $73 \%$ dos alunos só estuda;

- $71 \%$ dos alunos costumam acessar a Internet todo dia;

- $44 \%$ costumam acessar durante o dia, $45 \%$ costumam acessar durante a noite e $11 \%$ acessam em ambos os períodos;

- $48 \%$ dos alunos costumam acessar a Internet de casa e da Faculdade, 21\% acessam somente de casa e $11 \%$ acessam em casa, na Faculdade e no trabalho;

- $50 \%$ dos alunos utilizam a Internet principalmente para lazer (pelo menos $50 \%$ do tempo) e $36 \%$ utilizam principalmente para a Faculdade ou trabalho;

- $100 \%$ dos alunos utilizam e-mail, 90\% utilizam a Internet para pesquisa, 69\% para download de arquivos, 18\% participam de Chats, 13\% de jogos e 13\% de listas de discussão;

- $100 \%$ dos alunos utilizam o sistema operacional Windows;

- $57 \%$ dos alunos acessam a Internet através de cabo ou outra opção de conexão rápida;

- $\quad 9 \%$ dos alunos já tinham participado de algum curso de e-learning, sendo que destes, 7 alunos consideraram o curso excelente ou bom e 6 alunos consideraram regular ou ruim. 
Considerando apenas os alunos que responderam o Questionário de Avaliação ( $n=83)$, $77 \%$ afirmaram acessar o WebCT, em média, 1 a 2 vezes por semana e 19\% dos alunos afirmaram acessar 3 ou mais vezes por semana.

Além disso, 35\% deste grupo de alunos mencionaram terem alto interesse em Gestão de Pessoas (49\% médio interesse e 16\% baixo interesse).

\subsection{Modelo da Pesquisa}

O objetivo do modelo desta pesquisa, apresentada na Figura 13, é resumir todos os aspectos envolvidos neste trabalho. Após a definição do objetivo da pesquisa, a revisão bibliográfica foi iniciada, assim como o planejamento da metodologia de pesquisa, tendo sido realizadas de forma interdependentes. Como resultado, foram delineadas as dimensões e variáveis da pesquisa. O próximo passo consistiu na escolha e delineamento das técnicas e instrumentos de coleta dos dados primários. Por fim, a realização da pesquisa e a análise dos dados resultaram no atendimento aos objetivos propostos. 


\section{OBJETIVO}

Analisar a contribuição do e-learning, como atividade complementar do curso de graduação, para o desenvolvimento de competências do administrador

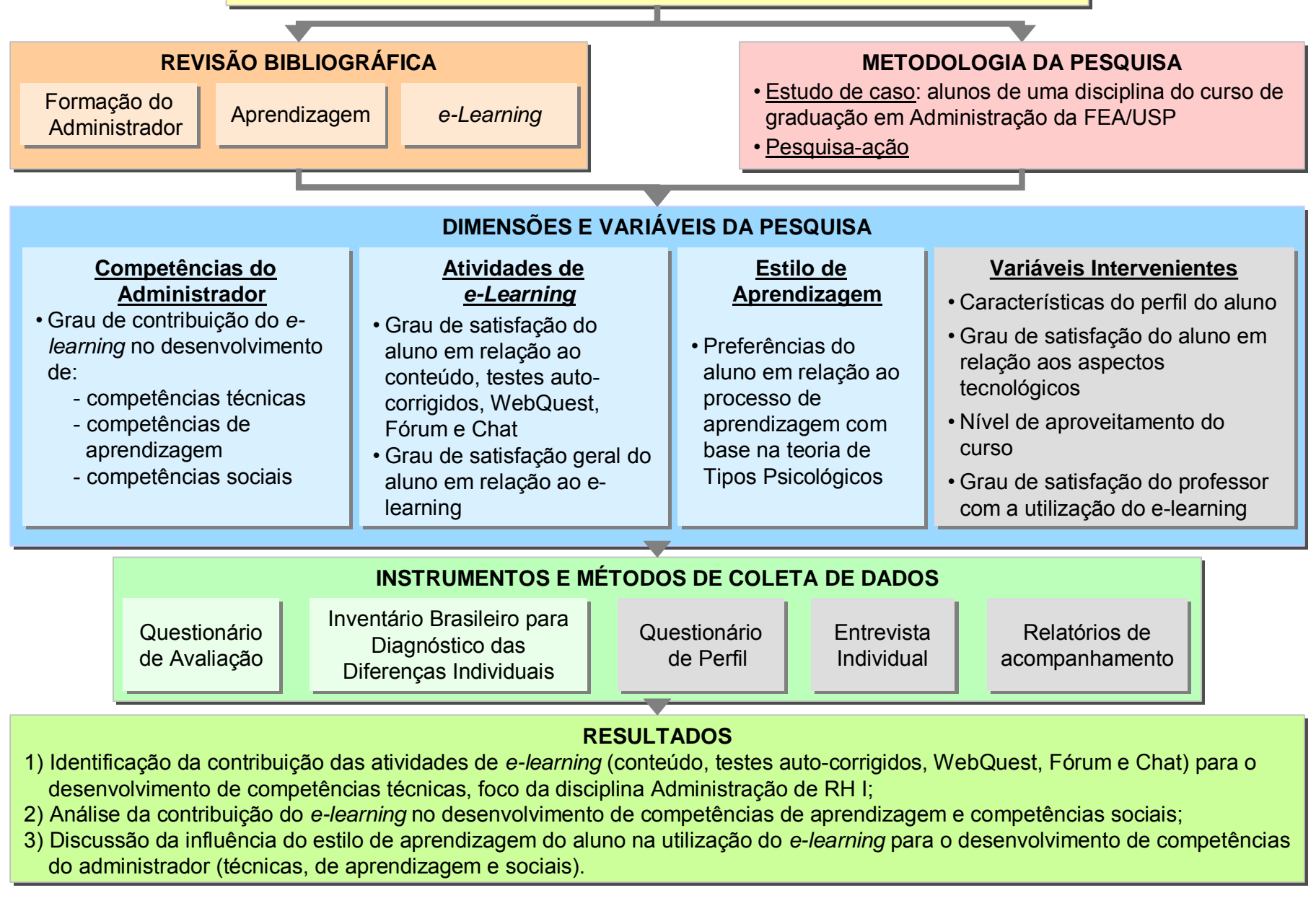




\section{ANÁLISE DOS RESULTADOS}

Os resultados foram agrupados em tópicos, organizados de acordo com os objetivos específicos desta pesquisa. Dessa forma, para cada objetivo, os dados são analisados em dois momentos. Primeiramente, é apresentada uma visão geral dos resultados de todas as variáveis pesquisadas. Em seguida, tendo em vista o grande número de dados coletados, optou-se por analisar de forma aprofundada somente os aspectos mais interessantes e significativos.

Antes de iniciar a apresentação dos resultados, é importante comentar as técnicas de estatística descritiva e testes de hipótese utilizadas na análise dos dados quantitativos coletados. De forma resumida, foram realizados os seguintes cálculos:

- Cálculo da freqüência, média e desvio padrão das respostas para cada variável pesquisada.

- Cálculo da média e freqüência das variáveis, realizando cruzamentos entre as dimensões estudadas e dessas dimensões com as variáveis intervenientes.

- Aplicação do teste Qui-quadrado com o objetivo de identificar associação entre as variáveis das três dimensões pesquisadas e dessas com as variáveis intervenientes. No caso da dimensão Atividades de e-Learning, algumas das variáveis foram escolhidas para esta análise com base nas tabelas de freqüências. Foram realizados diversos cruzamentos entre as variáveis do estudo, resultando em 67 associações, a níveis de significância entre $0,1 \%$ a $10 \%$. Desses testes com resultado significativo, 21 não estavam de acordo com a condição de utilização da prova de no máximo $20 \%$ das freqüências absolutas serem inferiores que 5 (MATTAR, 1998), não sendo possível agrupar os dados de forma a atender a essa condição. Apesar disso, tendo em vista o caráter exploratório deste estudo, optou-se por manter esses resultados, à medida que indicam uma tendência na associação entre as variáveis.

- Aplicação do teste Mann-Whitney para identificar diferenças significativas entre médias de dois grupos. Para aplicação dessa prova foram escolhidas algumas variáveis a partir de uma análise prévia das tabelas cruzando dimensões. Dos 16 casos em que o teste MannWhitney foi aplicado, a hipótese de igualdade entre as médias dos dois grupos (Ho) não foi rejeitada, a um nível de significância de 5\% e 10\%. 
Para possibilitar as análises realizadas, a escala ordinal utilizada no Questionário de Avaliação foi assumida como intervalar (PEREIRA, 1999); também, as notas com valor decimal atribuídas pelos alunos (ex.: 8,5) foram arredondadas para o próximo número inteiro maior.

Os resultados do Inventário Brasileiro para Diagnóstico das Diferenças Individuais foram analisados conforme fórmula proposta no instrumento, resultando na identificação do tipo psicológico do aluno.

\subsection{A contribuição das atividades de e-learning para o desenvolvimento de competências técnicas, foco da disciplina}

A contribuição das atividades de e-learning para o desenvolvimento de competências técnicas foi pesquisada a partir das opiniões dos alunos em relação a cada atividade de $e$ learning (conteúdo, teste auto-corrigido, WebQuest, Fórum e Chat), buscando identificar a sua percepção sobre a contribuição para o aprendizado da matéria e a sua avaliação sobre a forma de realização da atividade.

Primeiramente, com o objetivo de fornecer uma visão geral dos resultados obtidos, são apresentados a moda, média e desvio padrão (DP) das notas atribuídas pelos alunos para cada variável da Dimensão Atividades de e-Learning (Tabela 2) e para a variável "grau de contribuição do e-learning no desenvolvimento de competências técnicas", que integra a Dimensão Competências do Administrador (Tabela 3). Em seguida, os resultados mais interessantes são analisados com maior detalhe, agrupados nos tópicos: conteúdo, testes autocorrigidos, WebQuest, Fórum, Chat e satisfação geral em relação ao e-learning.

Tabela 2 - Distribuição das Opiniões dos Alunos sobre as Variáveis da Dimensão Atividades de e-Learning

\begin{tabular}{lccc}
\hline Questão & Moda* & Média* & DP \\
\hline Grau de satisfação em relação ao conteúdo & & & \\
O conteúdo disponibilizado era importante & 8 & 7,6 & 1,5 \\
O conteúdo disponibilizado era de qualidade & 8 & 7,8 & 1,3 \\
As páginas estavam bem organizadas & 8 & 8,0 & 1,3 \\
\hline Grau de satisfação em relação ao teste auto-corrigido & 8 & & \\
Os objetivos estavam claros & 10 & 8,5 & 1,9 \\
As instruções estavam claras & 7 & 7,3 & 1,8 \\
O nível de dificuldade estava adequado & 10 & 7,8 & 2,3 \\
Não tive problemas para realizar os testes auto-corrigidos & & & \\
\hline
\end{tabular}


Tabela 2 - Distribuição das Opiniões dos Alunos sobre as Variáveis da Dimensão Recursos de e-Learning (continuação)

\begin{tabular}{lccc}
\hline Questão & Moda* $^{*}$ & Média* $^{*}$ & DP \\
\hline Grau de satisfação em relação ao WebQuest & & & \\
Os objetivos estavam claros & 8 & 7,6 & 2,1 \\
As instruções estavam claras & 8 e 10 & 7,8 & 2,1 \\
O nível de dificuldade estava adequado & 8 & 7,7 & 1,9 \\
Não tive problemas para realizar as atividades & 10 & 7,8 & 2,0 \\
O feedback recebido foi adequado & 7 & 6,9 & 9,9 \\
\hline
\end{tabular}

\section{Grau de satisfação em relação ao Fórum}

Tive a oportunidade de expor minhas opiniões

O nível de participação foi adequado

A postura dos colegas foi adequada

10

8,4

1,9

Foi possível discutir os temas com profundidade e de forma crítica

7

8

6,8

1,9

7,1

Comentários de colegas foram úteis para meu aprendizado

6

5,4

2,3

\section{Grau de satisfação em relação ao Chat}

Tive a oportunidade de expor minhas opiniões

A postura dos colegas foi adequada

O número de participantes foi adequado

A duração de 30 minutos foi adequada

O contato e troca entre colegas foi maior do que na aula presencial

Foi possível discutir os temas com profundidade e de forma crítica

Comentários de colegas foram úteis para meu aprendizado

Não senti dificuldade para acompanhar e participar da discussão

\section{Grau de satisfação geral em relação às atividades de $e$-learning}

As atividades realizadas atenderam às minhas expectativas

Meu interesse em Gestão de Pessoas aumentou

O conteúdo da aula virtual (auto-estudo, discussão e Chat)

substituiu adequadamente a aula presencial

6

$5,8 \quad 2,4$

A integração entre as atividades online e presenciais foi adequada

$\begin{array}{ccc}10 & 8,0 & 2,0 \\ 6 & 6,0 & 2,4 \\ 7 & 6,6 & 2,3 \\ 5 \text { e } 7 & 6,0 & 2,4 \\ 8 & 6,4 & 2,8 \\ 7 & 5,2 & 2,5 \\ 7 & 5,8 & 2,4 \\ 10 & 6,7 & 2,6\end{array}$

\begin{tabular}{ccc}
7 & 7,0 & 1,7 \\
7 & 5,8 & 2,9 \\
6 e 7 & 5,3 & 3,1 \\
8 e 10 & 6,7 & 2,2 \\
8 & 6,7 & 2,6 \\
\hline
\end{tabular}

*Nota: $0=$ Péssimo e $10=$ Excelente 
Tabela 3 - Distribuição das Opiniões dos Alunos sobre o Grau de Contribuição das atividades de e-Learning no Desenvolvimento de Competências Técnicas

\begin{tabular}{lccc}
\hline Questão & Moda* & Média* & DP \\
\hline $\begin{array}{l}\text { Os TESTES auto-corrigidos contribuíram para o meu } \\
\text { aprendizado }\end{array}$ & 8 e 10 & 7,3 & 2,2 \\
$\begin{array}{l}\text { O WEBQUEST contribuiu para o meu aprendizado da } \\
\text { matéria }\end{array}$ & 8 & 7,4 & 2,1 \\
$\begin{array}{l}\text { As discussões no FÓRUM contribuíram positivamente para o } \\
\text { meu aprendizado }\end{array}$ & 6 & 6,2 & 2,5 \\
$\begin{array}{l}\text { As discussões no CHAT contribuíram positivamente para o } \\
\text { meu aprendizado }\end{array}$ & 7 & 6,4 & 2,1 \\
$\begin{array}{l}\text { De forma GERAL, a contribuição das atividades de } e- \\
\text { learning para meu aprendizado foi: }\end{array}$ & 7 & 6,8 & 2,0 \\
\hline
\end{tabular}

*Nota: $0=$ Péssimo e $10=$ Excelente

\subsubsection{O Conteúdo}

O conteúdo disponibilizado foi percebido pelos alunos como importante, de qualidade e bem organizado, considerando que mais de $50 \%$ das notas atribuídas para esses aspectos foram de 8 a 10. Analisando os resultados, é possível notar que, dentre os três indicadores analisados, apenas 2 alunos (2\%) atribuíram notas menores que 5, no caso, para a importância do conteúdo. Dessa forma, houve concordância entre os alunos sobre a avaliação do conteúdo disponibilizado, resultando em uma nota média de 7,8, considerando os três indicadores. Além disso, a moda e a mediana para os três indicadores são iguais a oito.

A avaliação positiva em relação à importância e qualidade do conteúdo disponibilizado é semelhante com os resultados verificados na experiência de CERRI e BARUFI (2001).

A partir de um relatório gerado pelo software WebCT foi possível identificar o número de vezes em que as páginas de conteúdo foram acessadas ( $\mathrm{N}^{\mathrm{o}}$ de Hits). Assim, os materiais mais acessados pelos alunos foram: as fotos tiradas dos alunos durante a primeira aula no laboratório de informática da FEA (200 Hits); as transparências das aulas sobre Modelos de Gestão de Pessoas (188 Hits) e Moderação Online (128 Hits); o texto "Dez passos para montar um currículo nota 10" (136 Hits); as transparências da aula sobre Gestão Estratégica de Pessoas (112 Hits); o Programa da Disciplina (105 Hits). É interessante notar 
que os materiais mais acessados também foram aqueles disponibilizados no início da disciplina.

O Gráfico 1 apresenta, de forma resumida, o número de Hits dos materiais disponibilizados, agrupados de acordo com a natureza do material. Os materiais das Aulas Virtuais incluíram as instruções para realizar uma pesquisa no ProQuest (banco de dados virtual), o vídeo sobre Educação Corporativa e, principalmente, os dois módulos de conteúdo do curso Abril-FIA. As transparências utilizadas nas aulas em classe também foram bastante acessadas. Com um número menor de acessos estão os materiais que comentavam o resultado de atividades realizadas em classe e os textos de apoio.

\section{Gráfico 1 - $N^{o}$ de Acessos aos Materiais Disponibilizados Online}

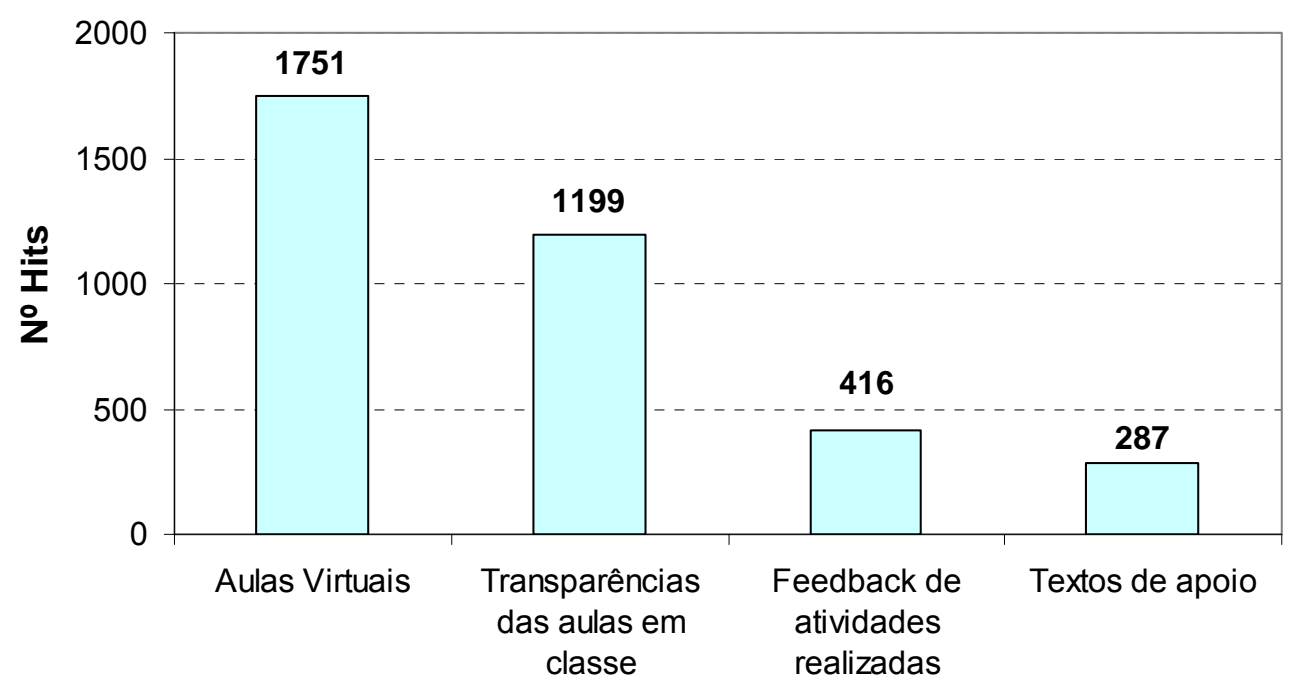

O primeiro módulo de conteúdo que fazia parte do curso desenvolvido pela Abril-FIA (“Gestão por Competências") foi acessado por 51\% dos 119 alunos que cursaram a disciplina, através de um novo ambiente também construído utilizando o software WebCT. Dos alunos que acessaram, foi possível verificar três níveis diferentes na intensidade de utilização do material, com base no número e tempo de acesso ao ambiente do curso. Assim, a Tabela 4 mostra a distribuição dos alunos que acessaram o curso por nível de utilização, indicando também que, quanto mais alto o nível de utilização, maior o número médio de Hits, calculado a partir do número de vezes que o aluno acessou a Homepage, atividades, ferramentas de comunicação e materiais nesse ambiente. O número total de Hits do primeiro módulo de conteúdo, considerando todos os alunos, foi 1211. 
Tabela 4 - Níveis de Utilização do Conteúdo do Curso Abril-FIA (1 ${ }^{\circ}$ Módulo)

\begin{tabular}{llcc}
\hline $\begin{array}{c}\text { Nível de } \\
\text { Utilização }\end{array}$ & \multicolumn{1}{c}{$\begin{array}{c}\mathbf{N}^{\mathbf{0}} \text { e tempo de acesso ao } \\
\text { ambiente do curso }\end{array}$} & $\begin{array}{c}\mathbf{N}^{\mathbf{0}} \text { médio } \\
\text { de Hits }\end{array}$ & $\begin{array}{c}\text { \% dos alunos que acessaram } \\
(\mathbf{n = 6 1 )}\end{array}$ \\
\hline Baixo & $\begin{array}{l}\text { Um acesso com duração } \\
\text { inferior a 5 minutos }\end{array}$ & 4 & $30 \%$ \\
Médio & $\begin{array}{l}\text { Um acesso com duração igual } \\
\text { ou superior a 5 minutos }\end{array}$ & 16 & $30 \%$ \\
Alto & Mais de um acesso & 34 & $40 \%$ \\
\hline
\end{tabular}

Alguns alunos aproveitaram muito bem o material disponibilizado, o que pode ser percebido no número total de Hits do aluno que mais utilizou o conteúdo ( 248 Hits) e no depoimento de outro aluno, enviado espontaneamente por e-mail:

[...] eu gostei demais do curso. Olha, realmente, se eu soubesse que era tão bom teria feito antes. Tanto assim que não agüentei e mesmo sem muito tempo fiz também os módulos 9, 13, 18 e 19. Olha, o curso está muitíssimo bem estruturado. A parte de gestão de competência, apesar de estar quase igual ao livro, dava pra entender tudo, claramente, na tranqüilidade de casa, prestando mais atenção. Realmente, acho que não é demais dizer que estes cursos nesse molde poderiam substituir com louvor as aulas teóricas de RH. Na classe, a gente poderia exercitar mais casos, exercícios. Ia ser realmente bom $[\ldots]$

No segundo módulo de conteúdo disponibilizado, sobre "Qualidade de Vida no Trabalho", não foi possível controlar o acesso da mesma forma, visto que o material foi disponibilizado no próprio ambiente da disciplina. Assim, a informação obtida se refere somente ao número total de acessos às diferentes páginas deste conteúdo, que totalizou 368 Hits; número muito menor que o verificado no módulo sobre "Gestão por Competências", possivelmente por ter sido disponibilizado no final do semestre (novembro), período em que os alunos estão mais sobrecarregados com trabalhos e provas. Dessa forma, parece ser mais interessante aproveitar o início do semestre para disponibilizar os conteúdos online.

Dentre as principais sugestões fornecidas pelos alunos para melhorar o material disponibilizado, coerentes com a proposta do curso, é possível citar: disponibilizar com maior rapidez as transparências apresentadas em classe; incluir maior número de textos extras para aprofundamento dos temas; manter o calendário atualizado com as atividades propostas; disponibilizar endereços de páginas na Internet e artigos sobre casos práticos relacionados aos assuntos tratados na disciplina. 
Conforme já comentado na revisão bibliográfica como uma das vantagens do $e$ learning, o conteúdo preparado para esta disciplina poderá ser facilmente aproveitado para outras turmas, possibilitando o aprimoramento e a atualização contínuos. Outra vantagem mencionada por uma das professoras envolvidas na pesquisa se refere à possibilidade de atendimento aos alunos que queiram se envolver mais com a matéria, aspecto que será comentado posteriormente a partir da variável nível de interesse em Gestão de Pessoas.

\subsubsection{Os Testes Auto-corrigidos}

Conforme já mencionado, foram propostos 4 testes auto-corrigidos utilizando o WebCT. O Gráfico 2, a seguir, mostra que 66\% dos alunos que cursaram a disciplina completaram todos os testes, o que é um número bastante razoável. Além disso, a nota média obtida nos testes foi 8,6, com desvio padrão de 1,4, demonstrando esforço por parte dos alunos para realizar os exercícios.

\section{Gráfico 2 - Distribuição dos Alunos por Número de Testes Auto-corrigidos Completados}

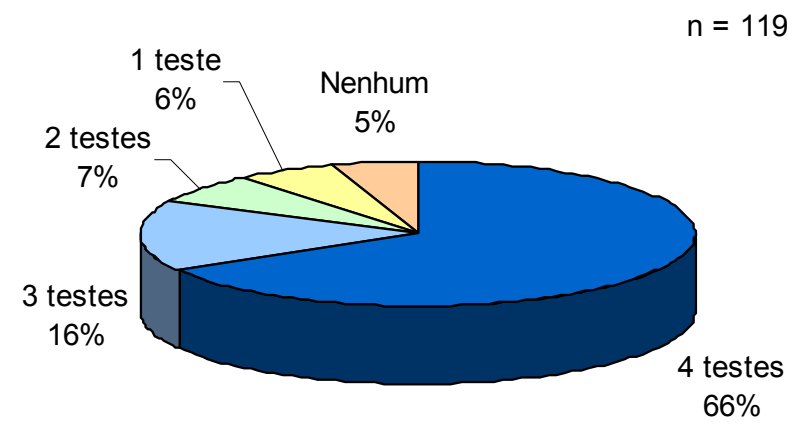

Quanto aos resultados da atividade, de acordo com os alunos que responderam o questionário, a percepção sobre a contribuição dos testes auto-corrigidos para o aprendizado foi positiva, visto que $52 \%$ dos 81 respondentes atribuíram notas 8,9 ou 10 para esse indicador; além disso, apenas $11 \%$ atribuíram nota menor que 5 e as notas mais freqüentes foram 8 e 10 (Gráfico 3). 
Gráfico 3 - Distribuição das Notas Atribuídas pelos Alunos sobre a Contribuição dos Testes Auto-corrigidos para o Aprendizado

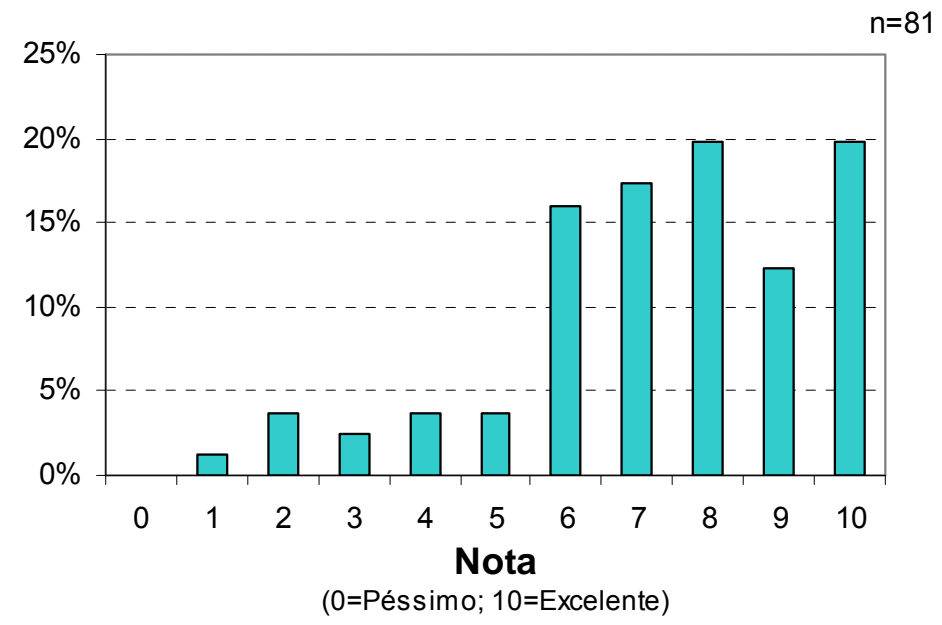

Este resultado é coerente com a literatura, que menciona a importância dos exercícios no aprendizado da matéria (CERRI e BARUFI, 2001; DUTTON, DUTTON e PERRY; 2002).

Um aspecto interessante foi verificado nos resultados: as notas relativas à contribuição dos testes auto-corrigidos para o aprendizado atribuídas pelos alunos com presença igual ou acima de 90\% nas aulas em classe foram, a um nível de significância de 5\%, mais baixas do que aquelas atribuídas pelos alunos com presença menor que $90 \%$, resultando da aplicação do teste qui-quadrado, ou seja, $19 \%$ dos alunos que estiveram mais presentes na sala de aula atribuíram notas menores do que 5 para esse indicador, enquanto que apenas $4 \%$ dos alunos com menor freqüência atribuíram notas nessa faixa (Gráfico 4).

Uma possível explicação seria os alunos que faltaram à aula presencial por alguma razão terem encontrado nos exercícios auto-corrigidos um apoio para revisar a matéria perdida, resultando em uma maior contribuição para o aprendizado.

Outra análise pode ser feita para esse resultado, considerando os comentários realizados pelos respondentes sobre os testes auto-corrigidos: dos alunos que atribuíram nota menor que 5 para a contribuição dessa atividade, aqueles que incluíram comentários, criticaram o nível de detalhe das questões e a necessidade de ler ou consultar o texto para saber a resposta correta, não sendo possível responder apenas com base nas discussões em classe. Embora outros alunos também tenham realizado essa observação, é possível que aqueles mais assíduos às aulas presenciais tenham sentido que seu esforço de aprendizado em classe não foi reconhecido conforme o esperado. Apesar disso, é importante ressaltar que 74\% 
dos alunos atribuíram notas entre 7 e 10 para a adequação do nível de dificuldade dos testes auto-corrigidos.

Gráfico 4 - Distribuição das Notas Atribuídas pelos Alunos sobre a Contribuição dos Testes Auto-corrigidos para o Aprendizado, por \% de Presença nas Aulas em Classe

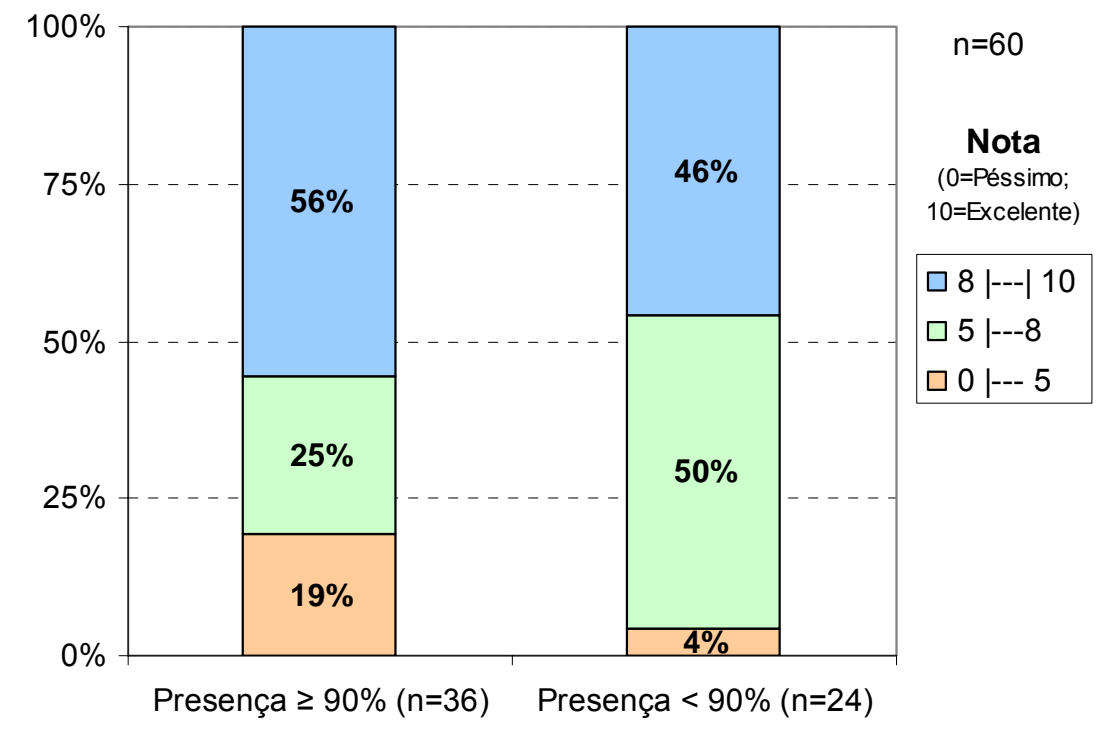

De qualquer forma, a crítica em relação ao nível de detalhe das questões teria um peso maior, se não fosse considerado que o objetivo dos professores, ao propor os testes autocorrigidos, era justamente incentivar a leitura dos textos. Objetivo este percebido por alguns alunos, conforme os comentários apresentados a seguir:

- "Os testes auto-corrigidos foram fundamentais no que concerne à minha compreensão do texto";

- "São um incentivo para a leitura dos textos, por isso, eu acho que deveria haver um exercício auto-corrigido para cada texto";

- "Os testes são uma boa verificação de leitura do livro, mas não vão além dele".

Apesar disso, de forma a atender melhor às necessidades dos alunos, poderiam ser utilizados dois grupos de questões: aquelas para estimular a leitura dos textos e questões adicionais para discutir aspectos mais gerais de cada conteúdo. A comunicação clara do objetivo da atividade também contribuiria para harmonizar as expectativas dos alunos, uma vez que, apesar da nota média para clareza dos objetivos dos testes auto-corrigidos ser 7,8, $14 \%$ dos alunos atribuíram notas iguais ou menores que 5 para esse indicador e um aluno incluiu o comentário: "Não está claro o objetivo dos testes, que estavam muito difíceis". 
Além da abrangência das questões, a realização dessa atividade envolve uma questão operacional: quando disponibilizar as respostas do exercício. A correção instantânea, logo após o término do preenchimento, pode proporcionar uma revisão mais cuidadosa dos próprios erros pelo aluno, pois este estará mais envolvido com a atividade, além de, conforme comentário de um aluno, minimizar a "ansiedade do aluno aguardando as respostas". Por outro lado, essa prática possibilita que alguns alunos tenham acesso ao gabarito antes de realizar o exercício. Para evitar essa situação, seria possível esperar até que grande parte dos alunos tenha completado a atividade para, então, disponibilizar a correção. Essa opção foi sugerida por um dos alunos através do questionário: "o gabarito só deveria ser disponibilizado depois que todos os alunos tivessem completado a atividade". O problema desse procedimento é o aluno não se interessar ou ter tempo para acessar o exercício e analisar seus erros após a correção, resultando em perdas para o aprendizado.

Dessa forma, se for levada em consideração a importância de se estimular a autoaprendizagem, na busca de uma mudança de postura em relação ao aprendizado, conforme proposto por WICK e LEÓN (1993) e apresentado anteriormente no Quadro 2, a correção instantânea parece estar mais coerente com esse comportamento. Os alunos genuinamente preocupados com seu aprendizado provavelmente vão optar pela realização do exercício ao invés de copiar o gabarito. Como complemento dessa estratégia, será necessário sensibilizar os demais alunos sobre a importância de aproveitar as oportunidades de aprendizado disponíveis.

KASHY et al. (2003) sugerem que a cópia high-tech está associada com níveis mais baixos de performance (resultado obtido em uma pesquisa realizada com 472 alunos, matriculados na disciplina de Introdução ao Cálculo do curso de engenharia). Os autores destacam a necessidade de os professores desenvolverem atividades com questões e formatos mais sofisticados de forma a ajudar os alunos a resistirem ao uso de soluções "fáceis".

Com o objetivo de aproveitar ao máximo o exercício para o aprendizado, a forma de apresentação das respostas após a correção precisa ser melhorada, pois alguns alunos tiveram dificuldade: "há confusão na hora de verificar as respostas dos testes", "o feedback recebido como quantos acertos no teste auto-corrigido não são tão intuitivos" (comentários dos alunos). Apesar de existirem limitações do próprio software, é preciso definir uma forma mais clara ou incluir explicações para entendimento da correção das questões. 
Um grupo muito pequeno de alunos (6\%) revelou ter tido problemas para realizar os testes auto-corrigidos (notas menores que 5), sendo que a nota mais freqüente atribuída para esse indicador foi 10 (Tabela 2).

Com o objetivo de sintetizar os principais aspectos discutidos neste tópico, a Figura 14 apresenta, no formato esquemático de causa e efeito, as possíveis explicações do resultado obtido em relação à contribuição do teste auto-corrigido para o aprendizado do aluno.

Figura 14 - Resumo das Possíveis Relações Explicativas da Contribuição do Teste Autocorrigido para o Aprendizado do Aluno

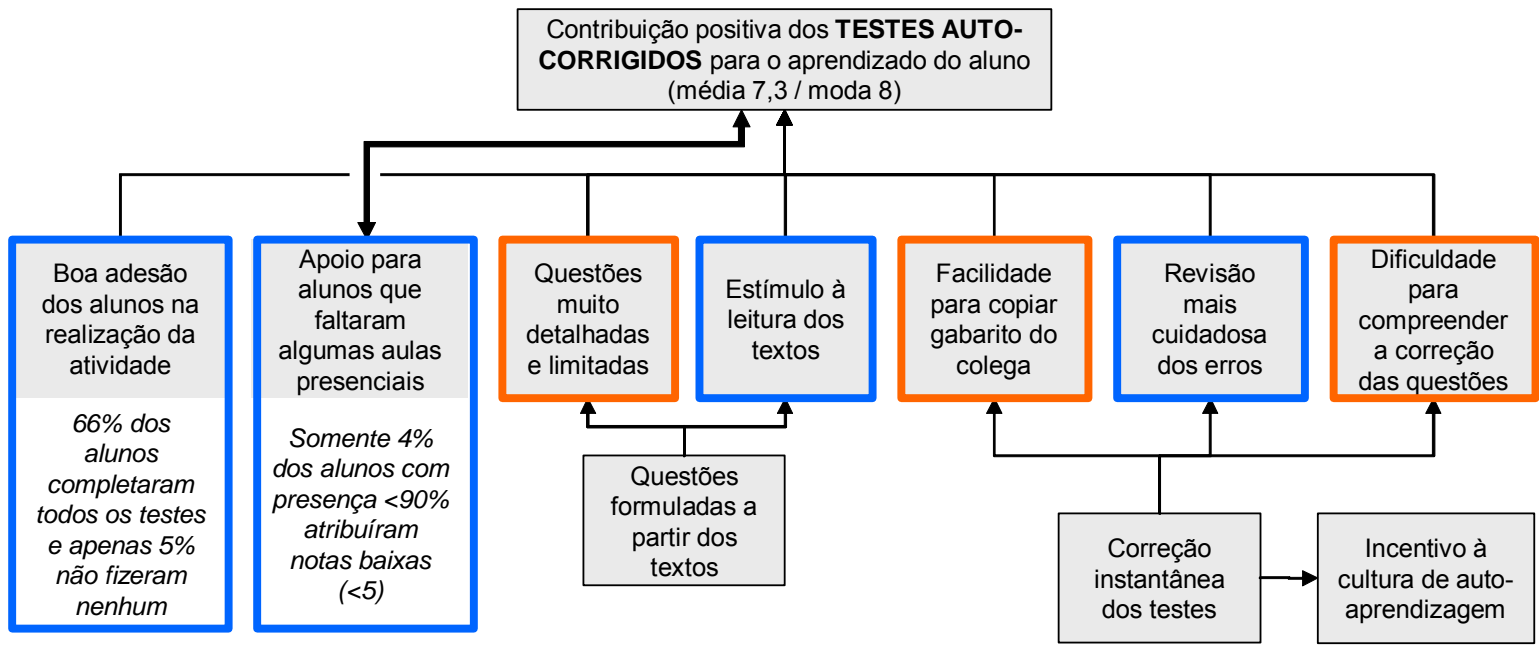

LEGENDA

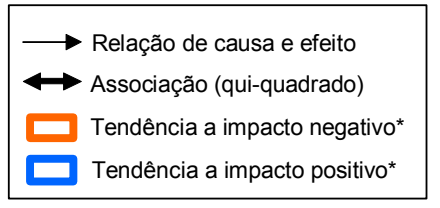

*Foi analisado o impacto apenas dos aspectos com ligação direta com a contribuição da atividade para o aprendizado do aluno.

\subsubsection{O WebQuest}

A atividade WebQuest, que, conforme detalhado na literatura, trata-se de uma pesquisa orientada na Internet, foi realizada por $61 \%$ dos alunos, em grupo, durante a aula virtual (estando a maior parte dos alunos presentes no laboratório de informática). De acordo com a percepção dos alunos, o WebQuest contribuiu de forma positiva para o aprendizado (Gráfico 5), uma vez que 62\% dos respondentes atribuíram notas entre 8 e 10 para esse indicador e a mediada e moda são iguais a 8. Alguns alunos incluíram comentários muito positivos sobre essa atividade: "foi a melhor parte do curso"; "acredito que o WebQuest se mostrou uma atividade surpreendente e com resultados muito melhores que meu pessimismo inicial frente a ele". Além disso, de acordo com a professora que acompanhou essa atividade, 
o nível dos trabalhos que resultaram do WebQuest foram muito superiores se comparado à atividade semelhante realizada em classe, visto que os alunos tinham conhecimento da teoria (aula teórica realizada antes) e tinham a Internet disponível para pesquisar, o que possibilitou ir além dos conteúdos abordados na aula teórica.

Por outro lado, alguns alunos ficaram insatisfeitos com a atividade, como relatou um aluno: "eu não gostei da atividade, o objetivo do exercício não estava claro, os dados fornecidos não eram suficientes para analisar a situação da Mtv, a base teórica também não era suficiente $[\ldots] "$.

\section{Gráfico 5 - Distribuição das Notas Atribuídas pelos Alunos sobre a Contribuição do} WebQuest para o Aprendizado

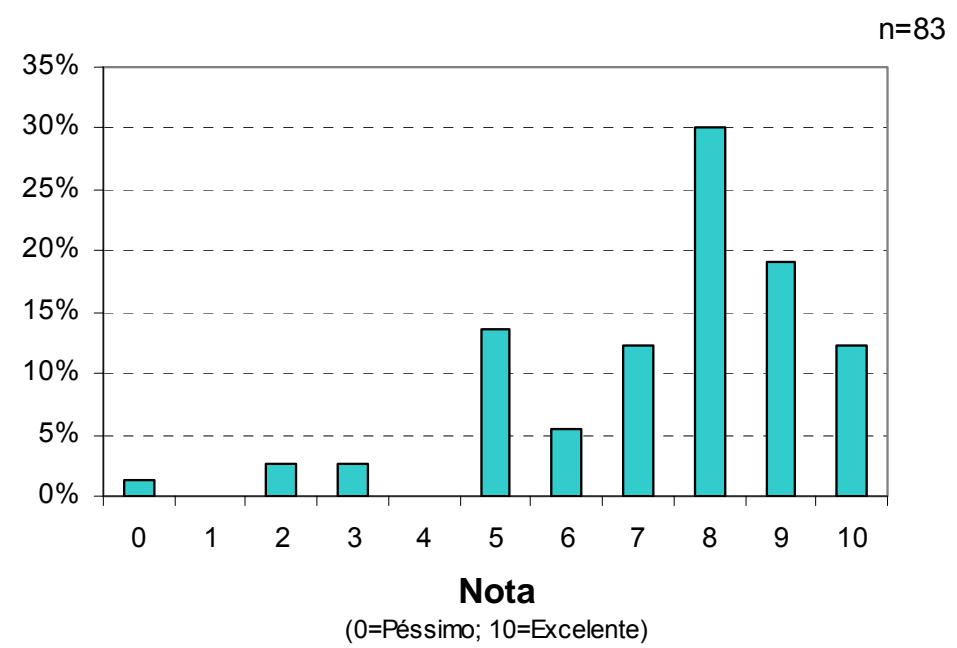

MARCH (1998) explica a contribuição do WebQuests para o aprendizado através da utilização de várias estratégias para aumentar a motivação do aluno, considerando que alunos motivados "não só se esforçam mais, como suas mentes estão mais alertas e prontas para fazer conexões". Entre as estratégias citadas estão: utilização de uma questão central que precisa ser respondida; utilização de recursos reais, como acesso direto a especialistas, pesquisa em bancos de dados e relatórios atuais; divulgação do resultado do trabalho, que pode ser enviado ou apresentado para avaliação e feedback; realização do trabalho em grupo.

Através da prova qui-quadrado, ao nível de significância de 5\%, identificou-se uma possível associação entre a contribuição do WebQuest para o aprendizado e o nível de interesse do aluno. Dos alunos que disseram ter alto interesse em Gestão de Pessoas, 56\% atribuíram notas 9 e 10 para a contribuição do WebQuest no aprendizado; uma freqüência 
muito maior, se comparada a $18 \%$ dos alunos de médio interesse que atribuíram notas na mesma faixa (Gráfico 6).

Gráfico 6 - Distribuição das Notas Atribuídas pelos Alunos sobre a Contribuição do WebQuest para o Aprendizado, por Nível de Interesse em Gestão de Pessoas.

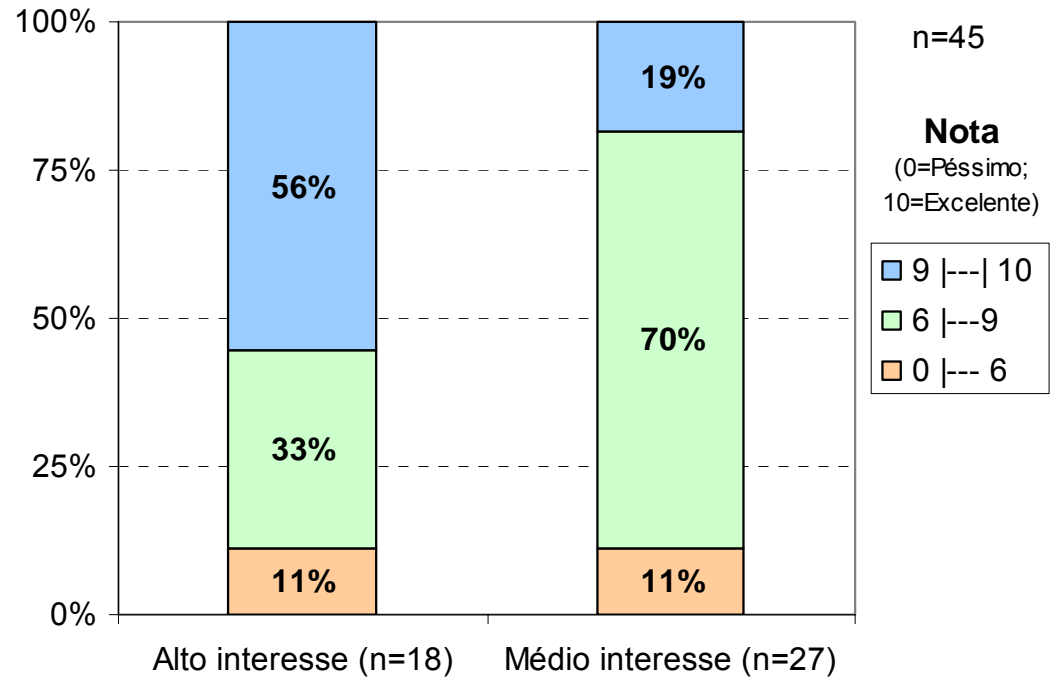

Também como resultado da aplicação do teste qui-quadrado, foi verificada associação entre a contribuição do WebQuest para o aprendizado e o número de mensagens enviadas ao Fórum, ao nível de significância de 5\%. O total de mensagens enviadas pelos alunos ao Fórum de discussão durante o semestre variou desde alunos que não enviaram nenhuma mensagem a alunos que enviaram 15 (Gráfico 7). O Fórum será discutido com mais detalhe no próximo tópico.

Considerando apenas os alunos que responderam todos os questionários da pesquisa, $72 \%$ dos que enviaram 4 ou mais mensagens atribuíram uma nota entre 8 e 10 para a contribuição do WebQuest no aprendizado; freqüência esta muito mais alta, se comparada aos $41 \%$ dos alunos que enviaram menos que 4 mensagens e atribuíram notas na mesma faixa (Gráfico 8). 
Gráfico 7 -Número de Mensagens Enviadas ao Fórum por Todos os Alunos da Disciplina e pelos Alunos que Responderam os Três Questionários da Pesquisa

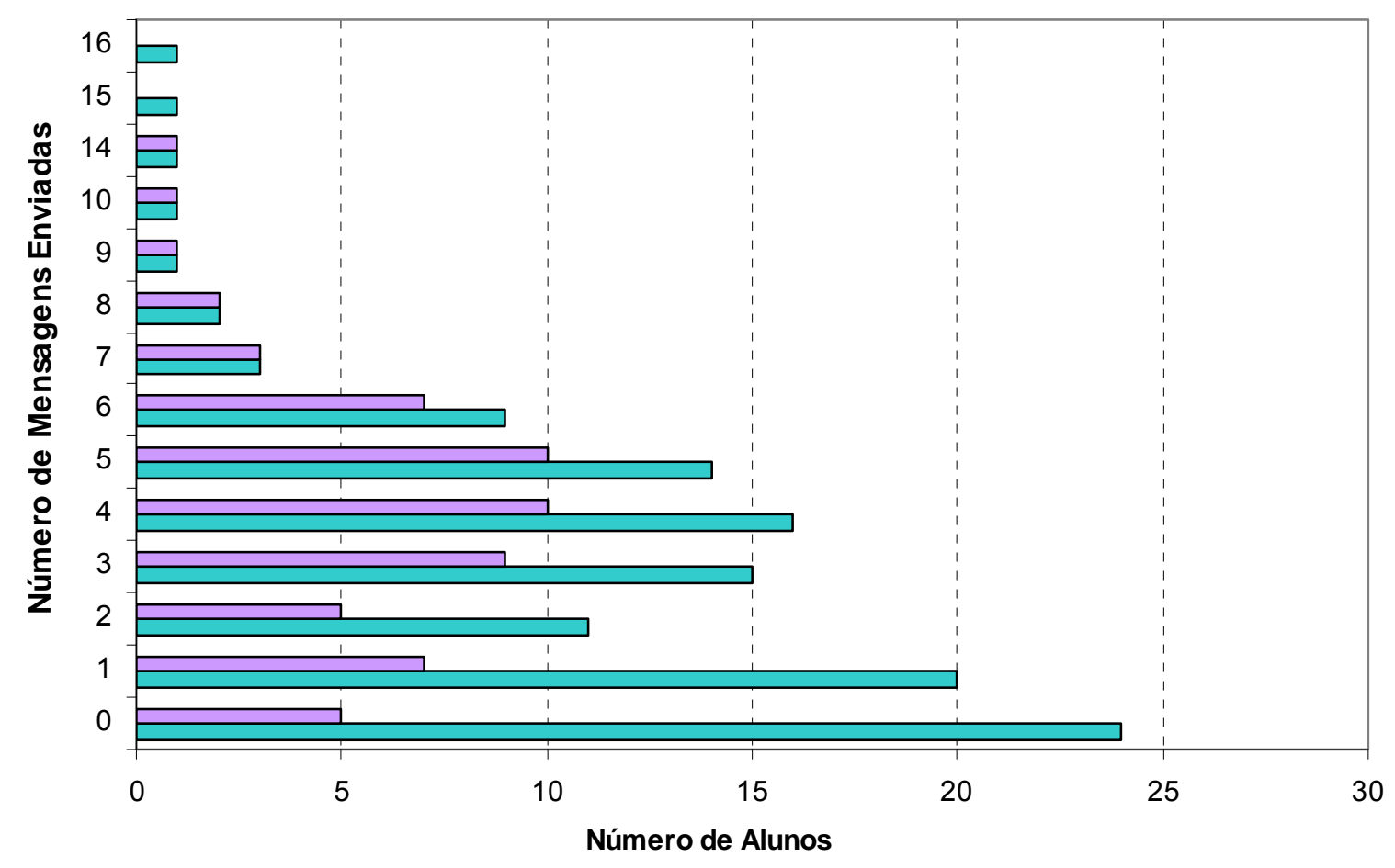

$\square$ Alunos que responderam os três questionários da pesquisa $(n=61)$

$\square$ Alunos da disciplina $(n=119)$

Gráfico 8 - Distribuição das Notas Atribuídas pelos Alunos sobre a Contribuição do WebQuest para o Aprendizado, por Número de Mensagens Enviadas ao Fórum

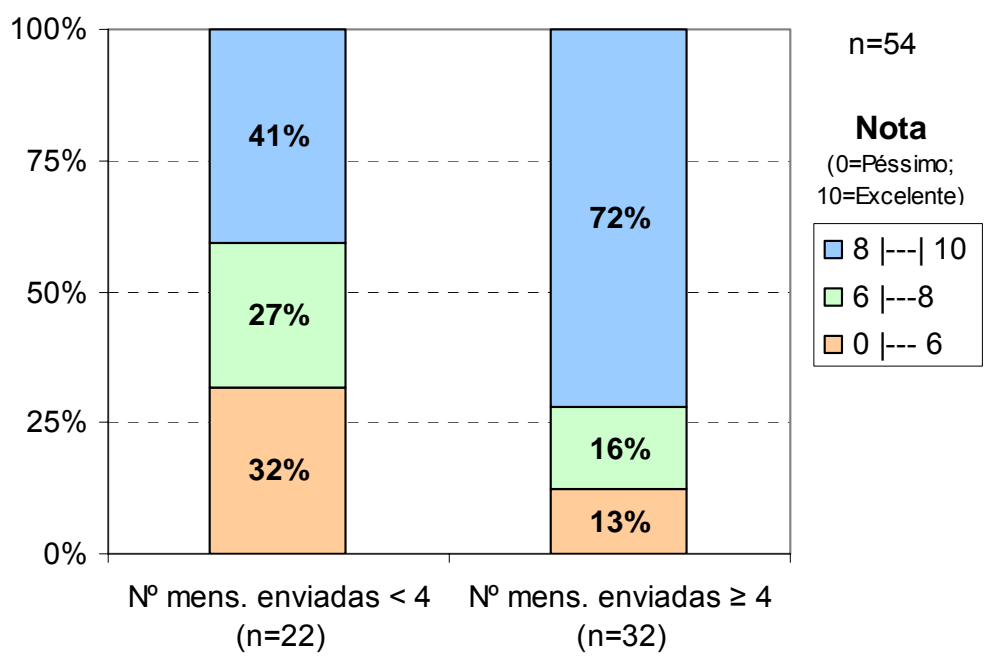

O resultado é interessante, uma vez que o Fórum é essencialmente colaborativo e o WebQuest foi desenvolvido em grupo. De acordo com ROMERO (1998, p. 25), "Para que se 
consiga construção conjunta, pressupõe-se participação [...] o que equivale dizer que o bom relacionamento interpessoal é fundamental". Nesse contexto, é coerente que os alunos mais participativos nas discussões do Fórum tenham percebido uma maior contribuição da atividade em grupo WebQuest para o aprendizado. Esta discussão será retomada no tópico seguinte.

O aspecto mais freqüente dos comentários incluídos no questionário em relação a essa atividade foi a falta de tempo para realizá-la. A duração é discutida por DODGE (1995), que define dois níveis de WebQuest com objetivos instrucionais diferentes:

- WebQuest Curta: o objetivo é a aquisição e integração do conhecimento; o aluno entra em contato com um número grande de informações, atribuindo sentido a elas; planejada para ser executada em uma ou três aulas.

- WebQuest Longa: o objetivo é ampliar e refinar o conhecimento; o aluno analisa profundamente um corpo de conhecimento e transforma em algo que outros possam utilizar; possui uma duração de uma semana a um mês.

No caso estudado, seria interessante aumentar a duração da WebQuest, planejada inicialmente para durar uma hora, considerando que os alunos com maior interesse no tema poderiam ter mais tempo para se aprofundar, gerando um resultado positivo para o aprendizado, conforme verificado no teste qui-quadrado. Para tornar a programação mais flexível, a atividade poderia ser iniciada durante a aula e ser concluída posteriormente.

Outra questão que precisa ser melhor equacionada é o feedback sobre os trabalhos entregues, que também foi enfatizada no comentário de alguns alunos. Esse foi o indicador mais mal avaliado dessa variável, uma vez que $21 \%$ dos alunos atribuíram notas menores do que 5. Apesar de ter sido realizado um Chat no final da aula, não foi possível concluir a atividade de pesquisa, mostrando aos alunos o que eles aprenderam, conforme sugerido por DODGE (1995).

Com o objetivo de sintetizar os principais aspectos discutidos neste tópico, a Figura 15 apresenta, no formato esquemático de causa e efeito, as possíveis explicações do resultado obtido em relação à contribuição do WebQuest para o aprendizado do aluno. 


\section{Figura 15 - Resumo das Possíveis Relações Explicativas da Contribuição do WebQuest para o Aprendizado do Aluno}

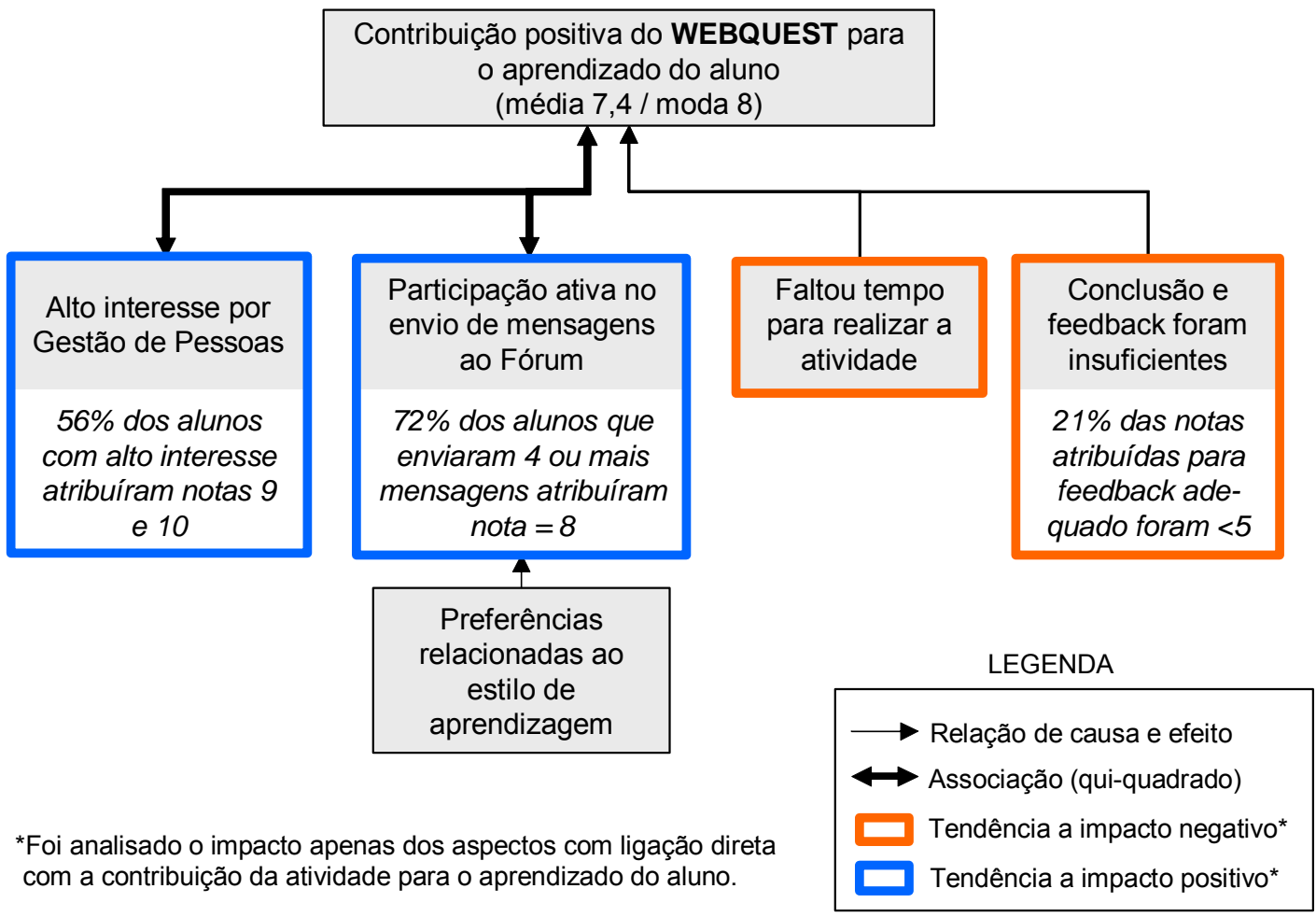

\subsubsection{O Fórum}

O espaço virtual de discussão assíncrona (Fórum) poderia ter sido mais bem utilizado pela maioria dos alunos, visto que, conforme já apresentado no Gráfico 7 , muitos não enviaram nenhuma mensagem. Apesar de a nota média para a adequação do nível de participação no Fórum ser 6,8, ao analisar o conteúdo das mensagens é possível verificar que o nível de interação e troca foi baixo. Do total de mensagens enviadas pelos alunos, apenas $11 \%$ eram respostas ao comentário de um colega; o restante estava limitado à inclusão de uma opinião, considerando o caráter obrigatório da participação (Gráfico 9). O percentual de 30\% de respostas encontrado em outra pesquisa (OLIVER e SHAW, 2003) reforça esta percepção quanto ao baixo nível de interação; fato esse também percebido pelos alunos, conforme apontado em alguns comentários incluídos no questionário de avaliação:

- "Houve pouquíssima participação. As pessoas não se envolveram na discussão e só participaram por obrigação";

- “O Fórum tecnicamente funciona bem, porém, acho que ninguém escreve nada além do que é exigido pelo professor, ou seja, seu propósito não foi concluído"; 
- “As mensagens enviadas ao fórum por um aluno dificilmente foram lidas pelos outros alunos";

- "Havia um número grande de comentários, às vezes não havia tempo para ler todos";

- “Não foi possível ler todas as opiniões do fórum, porém percebi que a maioria falava das mesmas coisas";

- "não achei o conteúdo exposto interessante ou inovador";

- "Não percebi análises críticas nos comentários".

É interessante notar que, apesar da baixa interação, os temas que geraram discussão entre os alunos (resposta ao comentário de um colega) foram os mais polêmicos: a avaliação de atividades online realizadas na disciplina ( $6 \%$ das mensagens), principalmente a utilização do Chat, e as questões propostas pelos professores (4\% das mensagens), em especial aquelas relacionadas ao processo de recrutamento e seleção na empresa. Também foram enviadas mensagens ao Fórum com o objetivo de entregar trabalhos realizados online, através do envio de arquivos anexados, e mensagens que não valiam nota de participação ("espontâneas") com comentários sobre aulas presenciais, dúvidas, divisão dos grupos para o trabalho final, entre outros assuntos.

\section{Gráfico 9 - Distribuição das Mensagens Enviadas ao Fórum pelos Alunos, Considerando seu Conteúdo (Assunto e Intenção)}

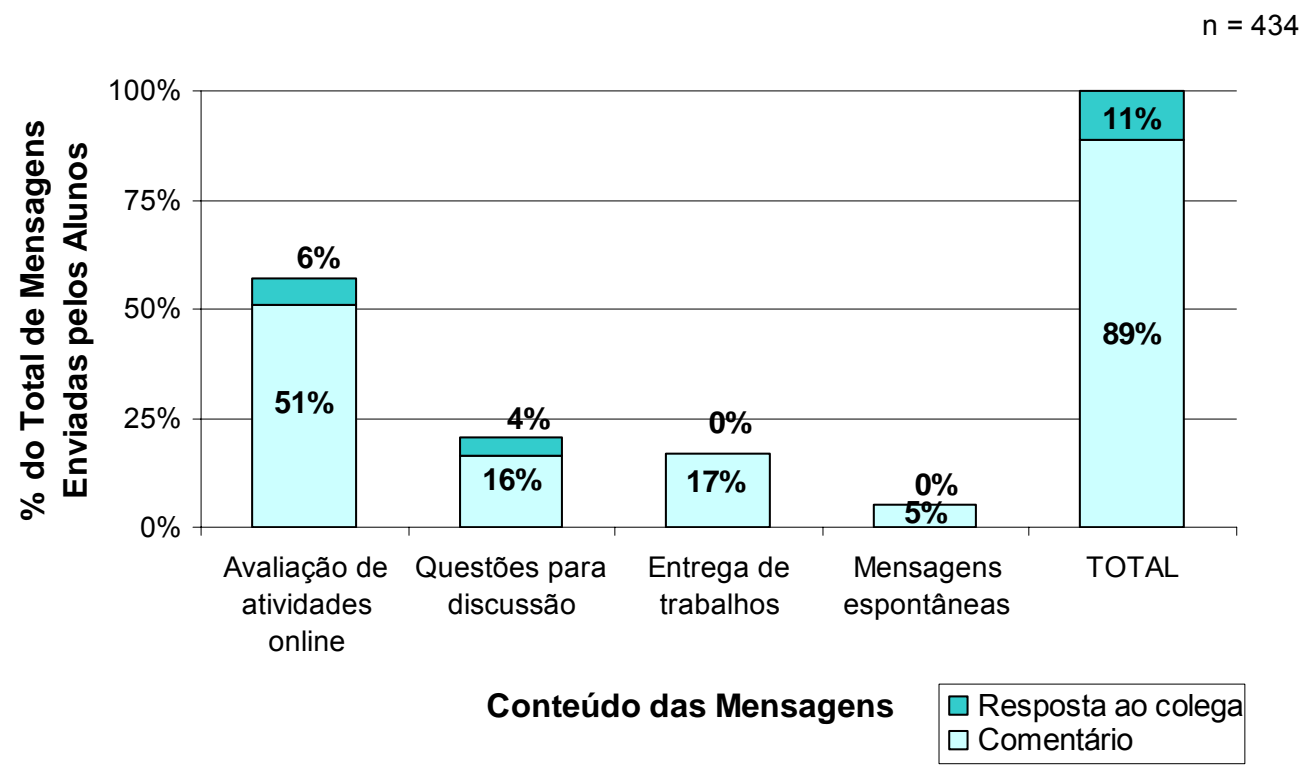

A falta de motivação para leitura dos comentários dos colegas e o caráter obrigatório da atividade podem explicar, pelo menos para parte dos alunos, a inclusão de opiniões com 
pouca análise crítica, situação também verificada em outras pesquisas (SCHRUM e BENSON, 2000). Como resultando, foi incluído um grande número de mensagens muito parecidas, que, por sua vez, acabaram desestimulando a leitura dos comentários dos colegas, impactando no nível de interação.

De acordo com OLIVER e SHAW (2003), o uso da avaliação para estimular a participação dos alunos parece resultar em um sucesso apenas superficial, visto que os alunos cumprem a tarefa sem necessariamente se envolver em um diálogo produtivo. Por outro lado, a não obrigatoriedade no envio de mensagens pode resultar em níveis ainda mais baixos de participação, conforme mencionado por alguns autores (MORRIS, MITCHELL e BELL, 1999; JACOBSOHN et al., 2002; OLIVER e SHAW, 2003). Dessa forma, uma solução seria desenvolver critérios de avaliação mais sofisticados, evitando que o simples crédito de nota pelo envio de mensagens mude o comportamento do aluno sem necessariamente melhorar o aprendizado (OLIVER e SHAW, 2003).

Embora a questão da obrigatoriedade seja importante, o papel desempenhado pelo professor, tutor ou monitor na discussão do Fórum tem sido mencionado na literatura como essencial no atingimento dos objetivos de aprendizagem dessa atividade (OLIVER e SHAW, 2003; LANDIS, 2001; ARBAUGH, 2000; HARA e KLING, 1999). Dessa forma, a dedicação que o professor poderá dispor para o planejamento e acompanhamento das atividades online passa a ser um aspecto chave a ser considerado, visto que o gerenciamento das mensagens pode exigir muito tempo dos alunos e, principalmente, dos professores, que precisam lidar com a expectativa do aluno em receber respostas imediatas (LEH, 2001; PRAMMANEE, 2003; SCHRUM e BENSON, 2000). Questão essa apresentada no capítulo dois como uma das desvantagens da comunicação mediada por computador (Quadro 11). Além disso, o número de horas de trabalho de professores e monitores verificado em outras pesquisas reforça esta exigência (SCHRUM e BENSON, 2000; REINHARD, YONEZAWA e MORGADO, 2000).

Apesar das diferenças entre os relatos encontrados na literatura e o caso estudado, era esperado que houvesse uma sobrecarga dos professores e monitores envolvidos. De acordo com a colocação de uma das professoras da disciplina pesquisada na entrevista, a preparação das atividades online exige três vezes o trabalho de um curso normal, mas por outro lado, o investimento é otimizado, pois pode ser reutilizado. Apesar disso, a sobrecarga diretamente ligada às atividades do Fórum foi percebida, principalmente, pela pesquisadora, que ficou 
responsável por moderar a discussão assíncrona. A sobrecarga observada pode ser explicada, principalmente, por dois fatores: (1) o caráter complementar das atividades, considerando que as atribuições das aulas presenciais se mantiveram, assim como os demais projetos em andamento; (2) o desenvolvimento das atividades online durante a realização da disciplina. Essa situação impossibilitou um maior envolvimento no Fórum, que pode ser observado pelo total de mensagens enviadas pelos monitores (apenas 11\% do total de 488 mensagens) e no comentário de um dos alunos: "O moderador deveria ter participado mais, tentando finalizar as discussões".

Apesar da participação obrigatória e da limitada participação dos monitores, ótimas contribuições foram enviadas ao Fórum, incluindo experiências pessoais e citações de autores relacionadas ao tema em questão. Além disso, $54 \%$ dos alunos que responderam os três questionários $(\mathrm{n}=61)$ conseguiram ler pelo menos 20 mensagens do Fórum durante o semestre, indicando que, apesar da interação ter sido baixa, os alunos leram muitas das mensagens enviadas pelos colegas (Gráfico 10).

\section{Gráfico 10 - Número de Mensagens Lidas no Fórum por Todos os Alunos da Disciplina e pelos Alunos que Responderam os Três Questionários da Pesquisa}

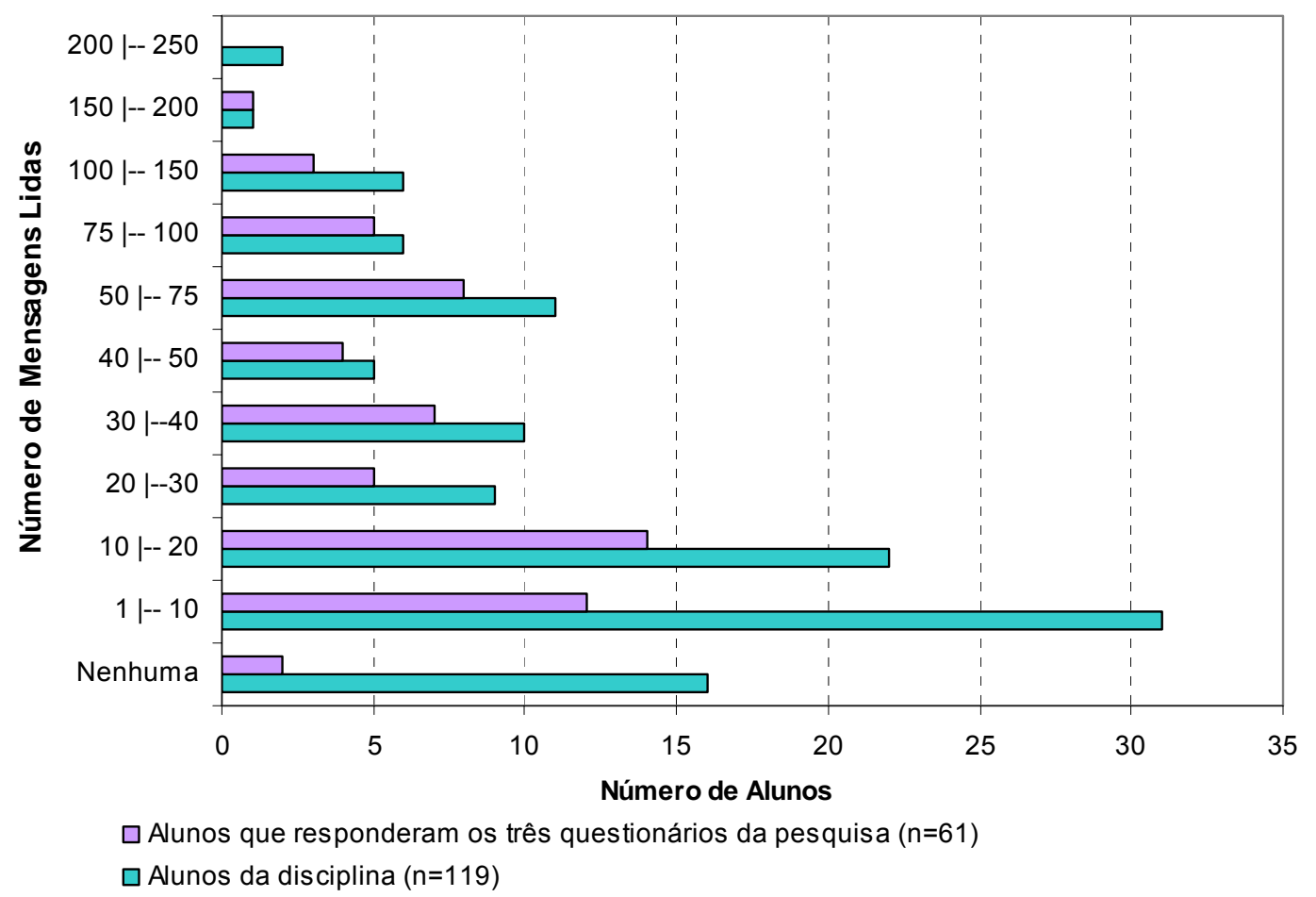

Esse fenômeno é comentado por MURRAY e MASON, quando explicam que "a maioria dos participantes dos fóruns de discussão são, na maior parte do tempo, receptores passivos de mensagens, ao invés de contribuidores ativos na discussão" (2003, p. 4, tradução 
da autora); ou seja, observadores (ou lurkers). Segundo os autores, apesar desse ser um tema ainda pouco pesquisado, a leitura de mensagens não pode ser considerada passiva, visto que, em muitas situações, pode estimular engajamento, pensamento e até reflexão. Assim, o fato de não ser enviada uma contribuição para a discussão não deve ser assumido como falta de envolvimento ou de aprendizado (MURRAY e MASON, 2003).

No caso desta pesquisa, o alto número de mensagens lidas por alguns alunos, pode indicar que, embora o nível de interação e troca tenha sido baixo, houve oportunidade para aprendizado.

O Gráfico 11 reforça a afirmação sobre o engajamento dos observadores, já que o aluno que mais leu mensagens (236), enviou apenas uma mensagem ao Fórum. Esse gráfico também mostra com maior detalhe a variação na forma de participação dos alunos, que não pode ser analisada somente com base nas mensagens enviadas. Da mesma forma que alguns alunos leram muitas mensagens e enviaram poucas, o inverso também foi observado; assim como, um dos alunos que mais leu mensagens, foi aquele que mais enviou. Um dos aspectos que influencia esse resultado é o estilo de aprendizagem do aluno, que será comentado posteriormente em relação ao nível de participação online.

\section{Gráfico 11 - Número de Mensagens Lidas no Fórum por Número de Mensagens Enviadas}

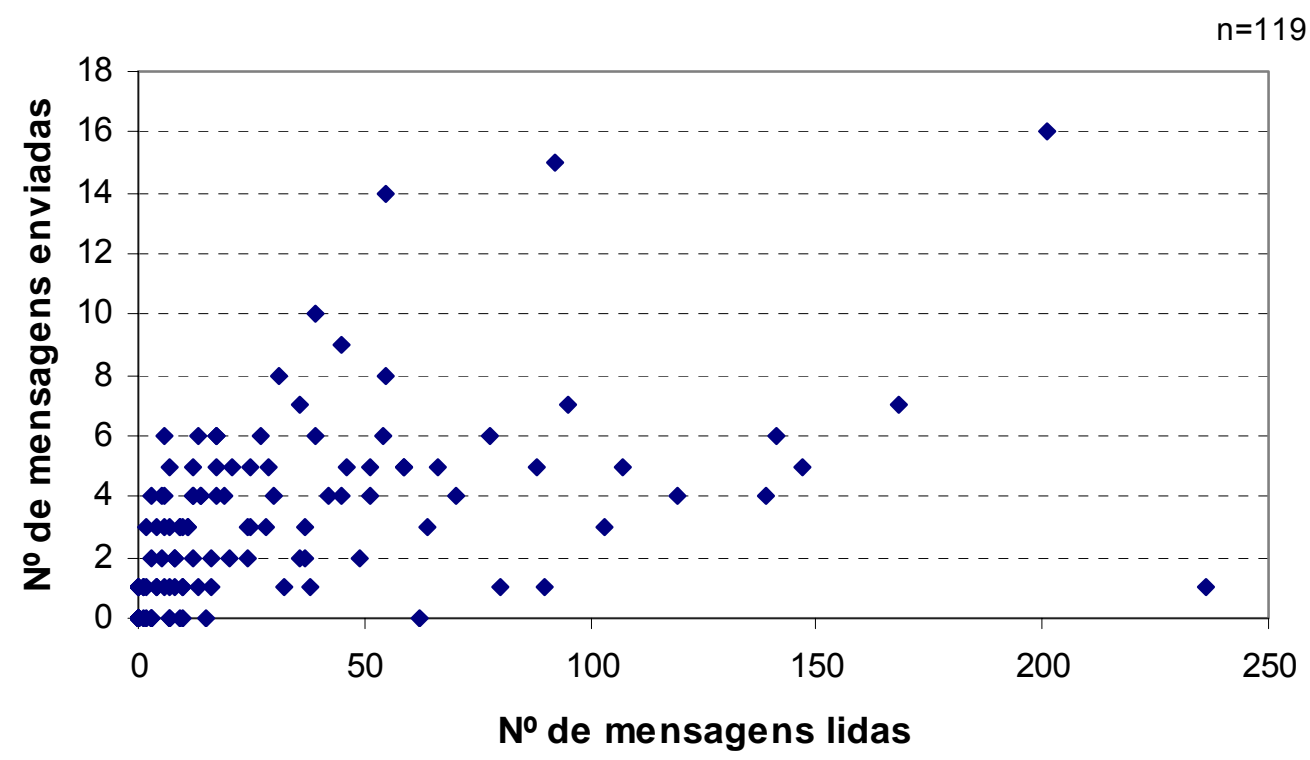

Coerente com a constatação de os alunos terem participado de forma diferenciada no Fórum, a percepção deles sobre a contribuição da discussão assíncrona para o aprendizado 
também variou (desvio padrão igual a 2,5); enquanto 17\% dos alunos atribuíram nota 9 ou 10 para esse indicador, $11 \%$ atribuíram nota entre 3 e zero (Gráfico 12).

\section{Gráfico 12 - Distribuição das Notas Atribuídas pelos Alunos sobre o Fórum}

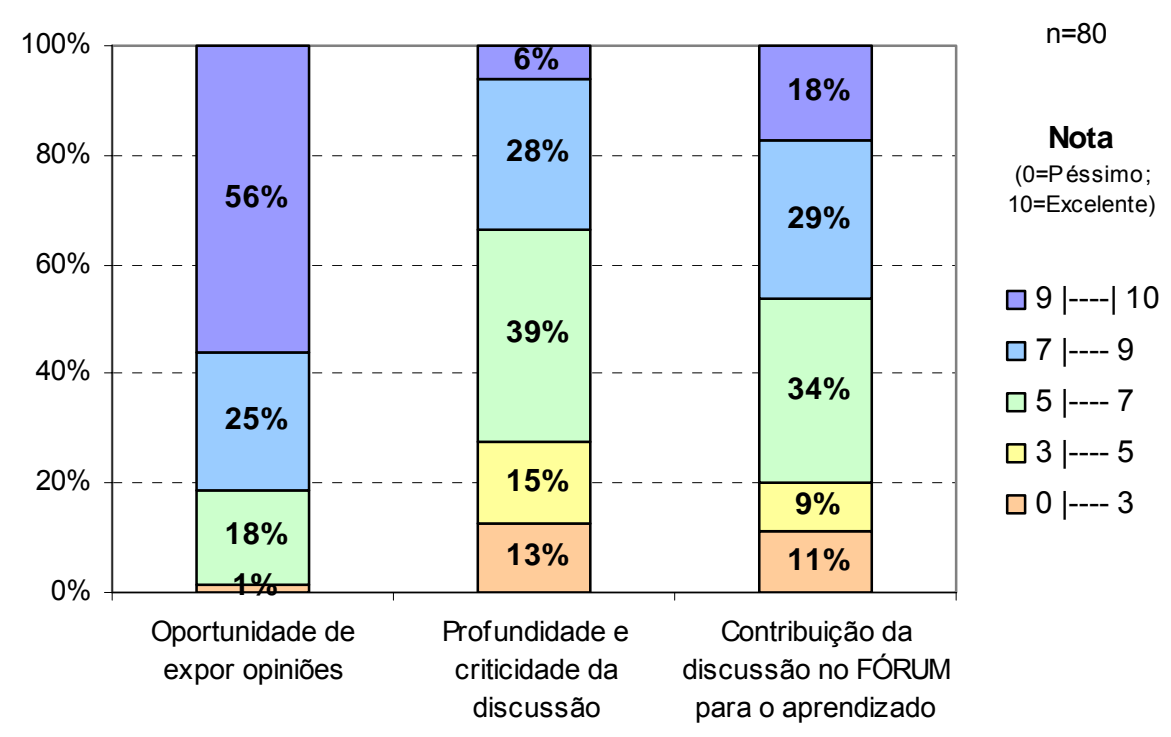

Apesar de as opiniões terem sido diversas, de forma geral, os alunos perceberam que houve contribuição do Fórum para o aprendizado, considerando a nota média de 6,1 e os comentários positivos de dois alunos:

- "Acho que o fórum, neste caso, é a melhor ferramenta para discussão em grupo, por ser mais calmo e abrir a oportunidade de discussões mais sérias e profundas";

- “Achei o fórum muito útil e aproveitável. [...] Todos tiveram opiniões bastante construtivas e estão contribuindo no meu aprendizado".

Esse resultado tende a confirmar o potencial do Fórum no estímulo ao envolvimento, compreensão e aprendizado dos alunos mencionado na literatura (MURRAY e MASON, 2003; BROWN, 2001).

De acordo com os alunos, o ponto forte do Fórum foi a oportunidade de expor opiniões, considerando que $41 \%$ atribuíram nota 10 para esse aspecto (Gráfico 12). O depoimento de um aluno reforça essa constatação: "Consegui expor minhas idéias com muita liberdade. E é possível comentar as idéias de cada um”. Essa percepção está coerente com a colocação de alguns autores sobre a possibilidade de a comunicação mediada por computador aumentar o nível de participação dos alunos, na comparação com a sala de aula (MURRAY e MASON, 2003; GU, 2003; ONLINE..., 2003). 
Por outro lado, como já foi discutido, faltou análise crítica e profundidade nas discussões, limitando as possibilidades de aprendizado (a nota média para este item foi 5,4). O Gráfico 12 reflete essa avaliação, visto que $27 \%$ dos alunos atribuíram nota menor que 5; percepção que também apareceu nos comentários dos alunos:

- “[...] por se tratar de opiniões, a profundidade do tema ficou em segundo plano";

- "Os temas foram tratados superficialmente pelos alunos e não acrescentaram muito".

Dessa forma, o baixo nível de interação e a superficialidade das discussões possivelmente limitaram as contribuições dessa atividade para o aprendizado. Por outro lado, a análise das notas atribuídas pelos alunos sobre a contribuição para o aprendizado, agrupadas pelo nível de participação no Fórum (Tabela 5 apresentada a seguir) reforçam uma possível relação entre o nível de participação e a contribuição para o aprendizado, visto que, de acordo com a pesquisa realizada por LEWIS, "as atividades de um grupo de discussão online precisam atingir um determinado nível de intensidade e engajamento dos participantes para resultar em aprendizado efetivo" (2002, p. 1, tradução da autora). Apesar de a associação não ser estatisticamente significativa e, também, da grande variabilidade das notas (principalmente no caso dos alunos de baixa participação, que atribuíram notas zero e 10), pode ser observada uma leve tendência dos alunos que mais participaram terem percebido uma maior contribuição do Fórum para o aprendizado, representada por uma nota média maior e um desvio padrão menor.

Tabela 5 - Média e Desvio Padrão das Notas* Atribuídas pelos Alunos sobre a Contribuição do Fórum para o Aprendizado, por Nível de Participação no Fórum**

Participação no Fórum

\section{Contribuição do Fórum para o aprendizado}

Média

\begin{tabular}{lll}
\hline BAIXA participação & 5,25 & 3,27 \\
MÉDIA participação & 6,27 & 2,94 \\
ALTA participação & 6,28 & 1,81 \\
\hline
\end{tabular}

6,27

6,28

Desvio Padrão

* Nota: 0 = Péssimo e $10=$ Excelente

**Baixa participação no Fórum: mensagens enviadas $<4$ e mensagens lidas $<20$

Média participação no Fórum: mensagens enviadas $\geq 4$ ou mensagens lidas $\geq 20$

Alta participação no Fórum: mensagens enviadas $\geq 4$ e mensagens lidas $\geq 20$

Embora alguns alunos tenham mencionado a falta de tempo como uma dificuldade para a participação no Fórum, os resultados mostram que esse não foi um fator decisivo. De acordo com o Gráfico 13, 50\% dos alunos que tiveram uma baixa participação no Fórum, 
mencionaram a falta de tempo; valor esse não muito diferente dos $40 \%$ dos alunos com alta participação que afirmaram ter a mesma limitação.

Gráfico 13 - Distribuição dos Alunos que Mencionaram a Falta de Tempo como uma Dificuldade na Realização das Atividades Online, por Nível de Participação no Fórum

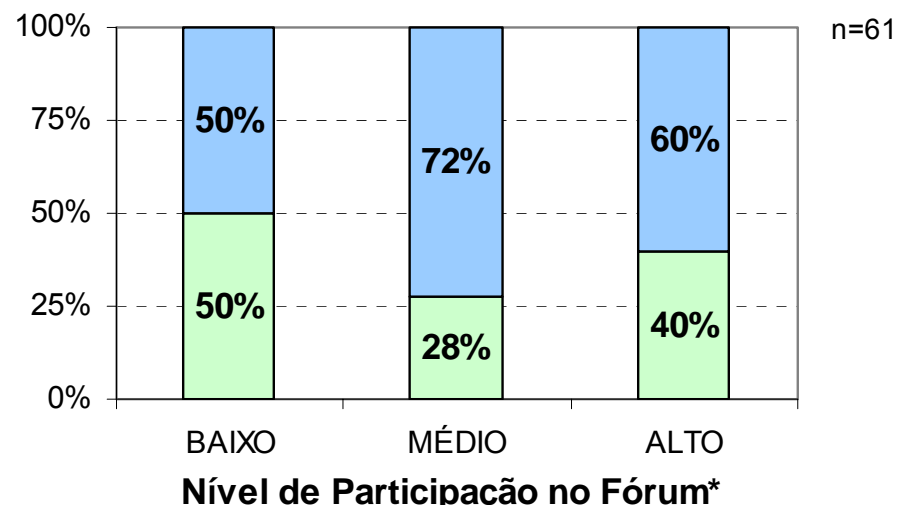

$\square$ Faltou tempo

**Baixa participação no Fórum: mensagens enviadas $<4$ e mensagens lidas $<20$

Média participação no Fórum: mensagens enviadas $\geq 4$ ou mensagens lidas $\geq 20$

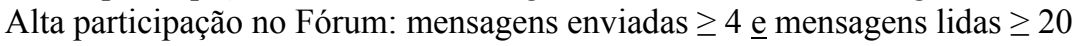

Por outro lado, a percepção dos alunos em relação à falta de tempo está associada, a um nível de significância de 5\%, com a contribuição percebida do Fórum para o aprendizado; resultado obtido a partir da prova qui-quadrado, indicando que os alunos que afirmaram terem falta de tempo, atribuíram notas mais altas em relação à contribuição do Fórum para o aprendizado. Esse resultado está coerente com as análises realizadas até o momento:

- existe uma tendência de os alunos que mais participaram no Fórum terem atribuído notas mais altas em relação à contribuição dessa atividade para o aprendizado (Tabela $5)$;

- a falta de tempo não parece estar relacionada ao nível de participação no Fórum (Gráfico 13).

O Gráfico 14 apresenta de forma mais clara a possível relação entre essas três variáveis, indicando que, dentre os alunos que afirmaram ter tido falta de tempo, aqueles que tiveram alta e média participação atribuíram notas bem mais altas em relação à contribuição do Fórum para o aprendizado; o inverso ocorreu no caso dos alunos com baixa participação. 
Gráfico 14 - Distribuição das Notas Atribuídas pelos Alunos em Relação à Contribuição do Fórum para o Aprendizado, por Falta de Tempo e por Nível de Participação no Fórum

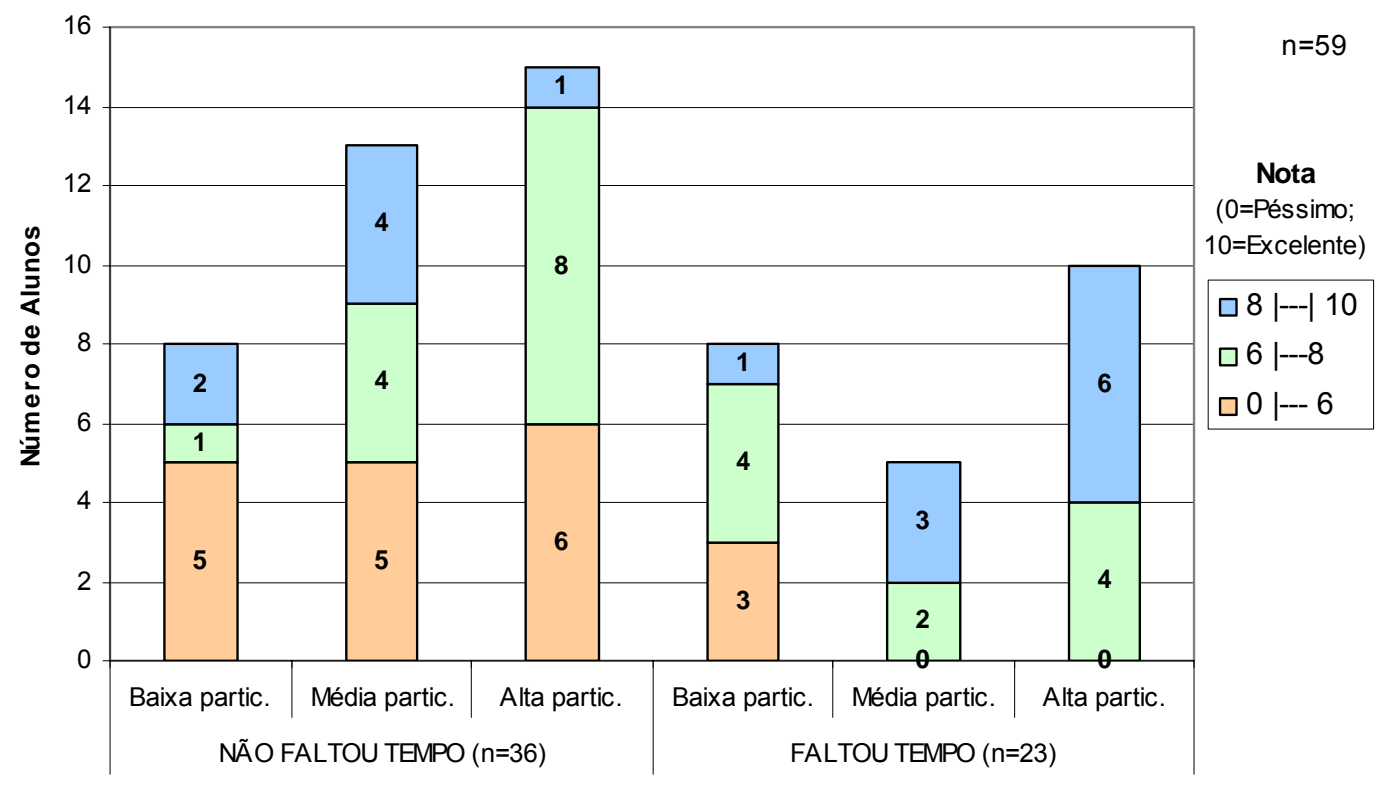

Nível de Participação no Fórum / FALTA DETEMPO

É possível que os alunos mais participantes, percebendo o potencial da atividade, acharem que, se tivessem mais tempo, poderiam ter intensificado sua participação. Outro aspecto que pode ser relacionado a esse resultado é a sensação de sobrecarga criada pelo grande número de mensagens (MURRAY e MASON, 2003; LANDIS, 2001); assim, aqueles alunos mais engajados na atividade (que perceberam maior contribuição para o aprendizado) provavelmente sentiram mais as limitações de tempo para participar da forma que gostariam.

No caso dos alunos que não mencionaram a falta de tempo como uma dificuldade, é possível que, dentre aqueles com maior participação, alguns não tenham percebido que o Fórum contribui de forma relevante para o aprendizado (notas abaixo de 6), considerando que o tempo utilizado nas atividades foi suficiente. Apesar disso, parece existir uma leve tendência de os alunos com maior participação terem atribuído notas mais altas em relação à contribuição para o aprendizado (notas entre 6 e 10).

Com base nas análises realizadas, o caminho para aprimorar a utilização do Fórum parece estar relacionado a um aumento na interação (troca) e na profundidade das discussões, estimulando a análise crítica. Como resultado, é possível que o nível de engajamento aumente, resultando em maior participação e maior oportunidade de aprendizado. Assim, dentre as melhorias a serem implementadas, destacam-se a utilização de critérios mais 
sofisticados de avaliação da participação e uma maior participação dos professores e monitores.

Com o objetivo de sintetizar os principais aspectos discutidos neste tópico, a Figura 16 apresenta, no formato esquemático de causa e efeito, as possíveis explicações do resultado obtido em relação à contribuição do Fórum para o aprendizado do aluno. 
Figura 16 - Resumo das Possíveis Relações Explicativas da Contribuição do Fórum para o Aprendizado do Aluno

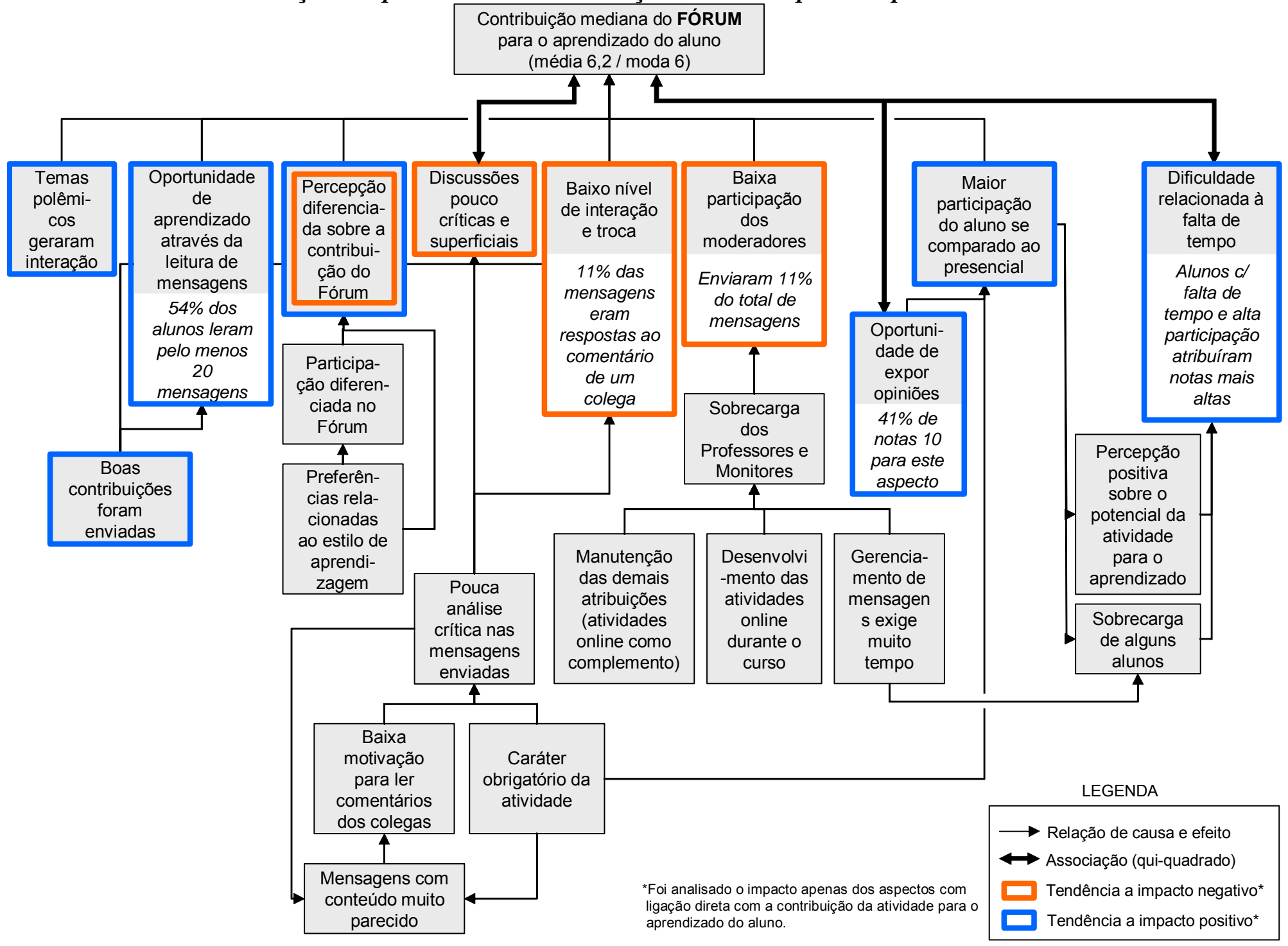




\subsubsection{O Chat}

A avaliação das discussões no Chat (ambiente em que todos os participantes estão conectados simultaneamente) foi, em determinados aspectos, semelhante ao Fórum; reforçando como vantagem desse tipo de atividade a oportunidade de o aluno expor suas opiniões (Gráfico 15); aspecto associado à contribuição percebida do Chat para o aprendizado ao nível de significância de $1 \%$.

\section{Gráfico 15 - Distribuição das Notas Atribuídas pelos Alunos em Relação ao Chat}

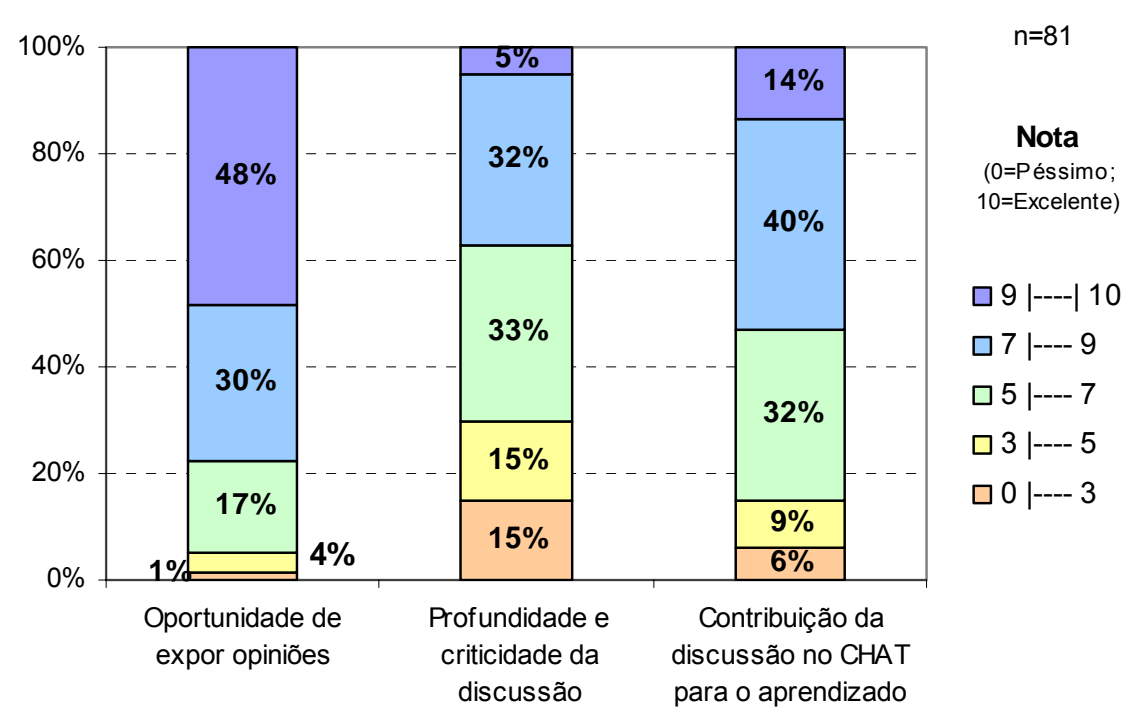

Com base nas gravações do Chat, é possível afirmar que a troca de idéias e interação entre os participantes foi maior do que no Fórum; e, possivelmente, maior que na aula presencial, considerando que a nota média atribuída pelos alunos em relação à troca entre colegas ser maior do que na aula presencial foi 6,4 , com moda igual a 8 . Além disso, a participação dos alunos em geral também foi maior conforme mencionado na literatura (HUTCHINS, 2001), principalmente no caso daqueles que não costumam participar em sala de aula, aspecto também percebido por eles:

- "Outra vantagem [do Chat] é possibilitar a alta participação de todos os alunos com um número quase ilimitado de emissão de mensagens";

- "O resultado final foi positivo, pois o Chat possibilitou que todos os alunos pudessem opinar"; 
- “[o Chat] promoveu a participação dos alunos de um modo nunca visto, mesmo aqueles que jamais participariam em sala não tiveram medo de se expor e participaram livremente, sem o constrangimento que costuma acompanhar numa sala de aula real";

- "no Chat as pessoas mais tímidas tiveram maior participação";

- "Bastante interessante, pois todos participaram bastante. Eu também dei algumas opiniões pessoais no Chat, algo que provavelmente não teria feito se fosse em sala de aula".

As professoras também mencionaram terem percebido uma maior participação, no Chat, de alunos que normalmente participam pouco em classe; resultado coerente com a pesquisa realizada por PARKER e GEMINO (2001), que identificou o ambiente online como fator que ajudou no aumento do nível de interação entre os alunos.

É possível que esse maior nível de interação e participação possa explicar o fato de a moda e mediana das notas atribuídas pelos alunos em relação à contribuição do Chat para o aprendizado serem iguais a 7; um pouco maior que a nota 6 calculada para a contribuição do Fórum.

De forma semelhante, na pesquisa realizada por CHOU (2001), os alunos demonstraram um maior engajamento na discussão síncrona, através de um número maior de questões e respostas; enquanto na discussão assíncrona, os alunos pareceram estar mais interessados em expressar suas opiniões, ao invés de desafiar as visões uns dos outros.

Esse resultado sugere a riqueza do Chat, visto que "propicia a criação de laços sociais, oferece momentos para a criação de materiais coletivos, brainstorming e tomada de decisões" (CHAVES, 2001), principalmente se somado a relatos positivos registrados pelos alunos:

- "achei muito interessante as opiniões das pessoas e posso dizer que aprendi com elas";

- "as discussões foram extremamente enriquecedoras e os comentários dos moderadores, muito propícios e pertinentes".

Assim como o resultado obtido com a atividade WebQuest, também foi identificada uma associação entre a contribuição do Chat para o aprendizado percebida pelos alunos e o nível de interesse deles em Gestão de Pessoas, a um nível de significância de 5\% (prova quiquadrado). O Gráfico 16 mostra que os alunos com alto interesse na matéria atribuíram notas mais altas em relação à contribuição do Chat para o aprendizado, indicando que o maior 
interesse no assunto estimulou-os a perceberem a discussão como mais produtiva. Essa tendência também foi observada em relação ao Fórum, porém não estatisticamente significativa.

\section{Gráfico 16 - Distribuição das Notas Atribuídas pelos Alunos para a Contribuição do Chat no Aprendizado, por Nível de Interesse em Gestão de Pessoas}

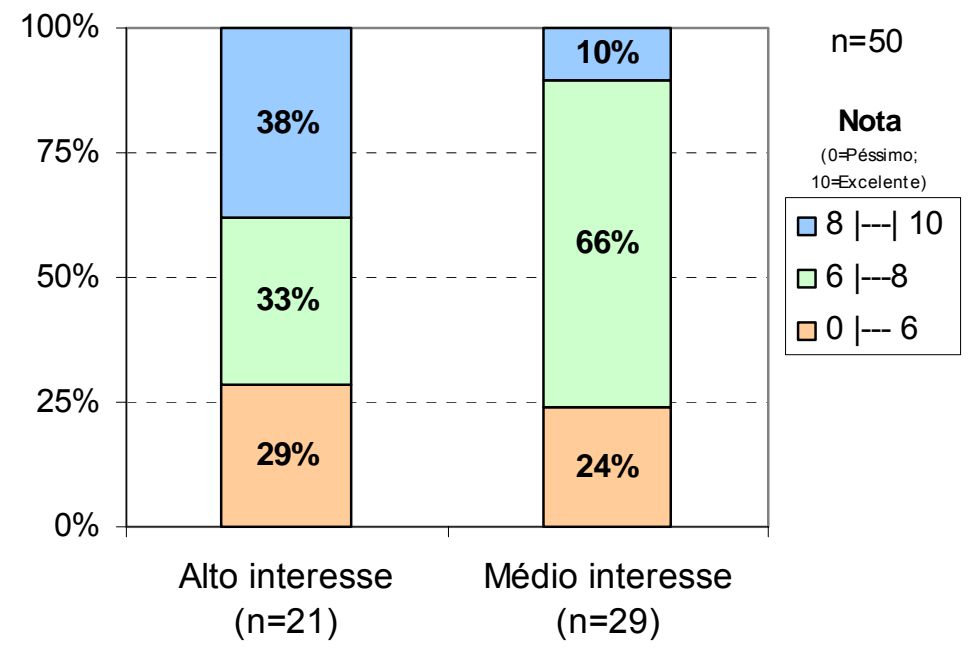

A proximidade dos resultados obtidos no Chat e Fórum é reafirmada, através da prova qui-quadrado, que identificou uma associação entre as notas atribuídas pelos alunos em relação à contribuição para o aprendizado do Chat e do Fórum, a um nível de significância de 0,1\%. Conforme explicitado no Gráfico 17, os alunos que atribuíram notas altas para a contribuição do Chat, fizeram o mesmo em relação à contribuição do Fórum; o que se repete para as notas médias e baixas.

Apesar das diferenças entre o Chat e o Fórum, discutidas no capítulo dois, essas duas formas de comunicação online são altamente interativas e baseadas na linguagem escrita; provavelmente, agradando mais a alunos com determinado estilo de aprendizagem, que puderam aproveitar melhor essas experiências e, como resultado, perceberam uma maior contribuição para o aprendizado.

A partir da forte associação entre essas duas variáveis (Gráfico 17), é possível explicar a associação verificada entre a contribuição do Chat para o aprendizado e a falta de tempo dos alunos, a um nível de significância de 10\%, visto que o Chat, por ser síncrono, não parece gerar sobrecarga para seus participantes como no Fórum. Dessa forma, a tendência de os alunos que atribuíram notas altas para a contribuição do Fórum e do Chat serem os mesmos e a associação entre a contribuição do Fórum e a falta de tempo, verificada a um nível de 
significância de $5 \%$ e já discutida no tópico anterior, podem justificar a associação entre a contribuição do Chat e a falta de tempo.

Gráfico 17 - Distribuição das Notas Atribuídas pelos Alunos em relação à Contribuição do Fórum e do Chat para o Aprendizado

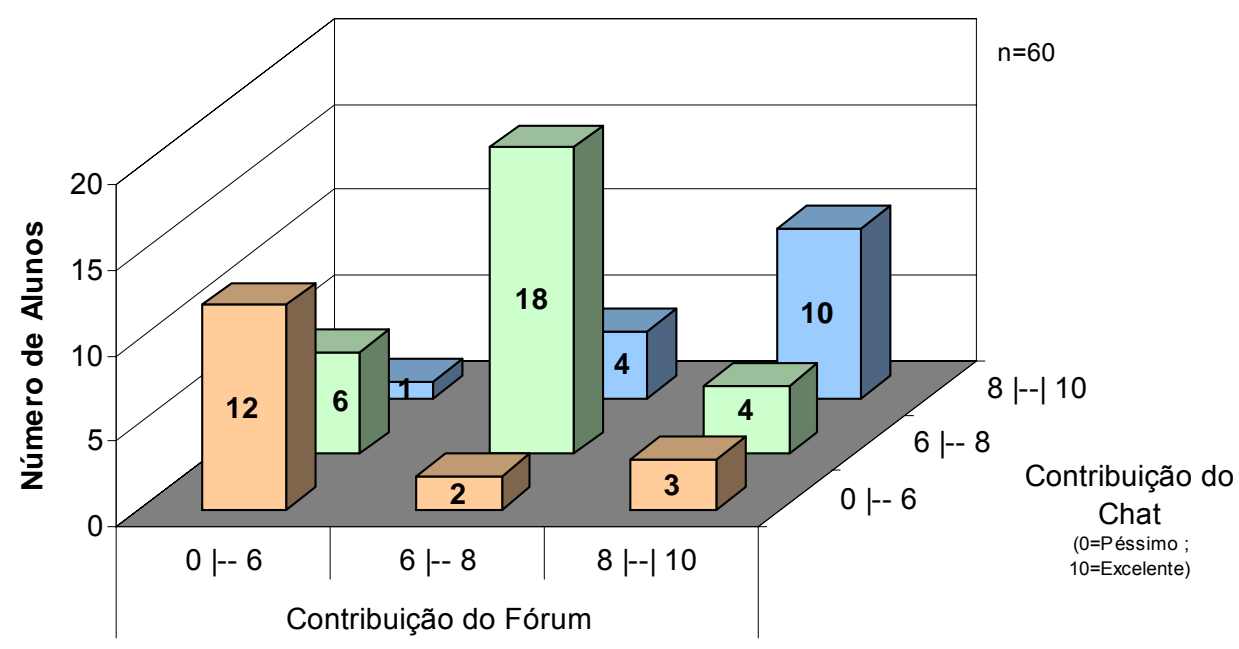

A mesma associação verificada entre as notas relativas à contribuição para o aprendizado do Fórum e Chat não foi identificada nos demais cruzamentos possíveis das atividades realizadas (testes auto-corrigidos, WebQuest, Fórum e Chat); exceto no caso do Chat e WebQuest, variáveis associadas, a um nível de significância de 10\% (prova quiquadrado), possivelmente devido ao caráter colaborativo de ambos.

Embora a avaliação do Chat em relação ao nível de participação e à contribuição percebida para o aprendizado tenha sido positiva, ficou claro que a sua utilização precisa ser melhorada, principalmente no que se refere à profundidade e análise crítica das discussões (Gráfico 15, já apresentado). Esse aspecto e suas possíveis explicações foram abordados nos comentários dos alunos:

- "Postura inadequada de alguns; falta de tempo e de foco deixaram discussões superficiais";

- "Como foi visto, muitos alunos não respeitaram o assunto, horário e sala do Chat, comprometendo uma discussão que poderia ser muito frutífera";

- “As discussões não contribuíram para o aprendizado e eram difíceis (quase impossíveis) de serem acompanhadas"; 
- 'Não há um fluxo de idéias que nos permitam aprofundar a discussão. Não há linearidade nas idéias discutidas";

- "Achei o Chat a parte mais confusa de todo o trabalho realizado virtualmente, as discussões foram muito superficiais, o comportamento dos colegas foi inadequado, pouco tempo de aula e muita confusão de idéias. Além disso, acho bastante complicado acompanhar a leitura e ao mesmo tempo criar opiniões para serem incluídas nas discussões";

- “minha participação foi um pouco prejudicada já que eu digito muito devagar e quando eu terminava a digitação outro assunto já estava em discussão";

- "Os comentários ficavam perdidos em meio às conversas paralelas";

- "O tempo de Chat muito curto e o número de pessoas muito grande";

- “discussão boa, mas sem conclusão”.

Segundo depoimento de uma das docentes que participaram do Chat, esses comentários procedem, visto que é difícil para o professor/monitor encaminhar uma discussão mais aprofundada de um tópico, evitar "conversas paralelas" e, ao mesmo tempo, incentivar a participação de todos. $\mathrm{O}$ aspecto positivo observado foi a participação no Chat de alunos mais introvertidos, com maior dificuldade de verbalização em aulas presenciais, aspecto já comentado anteriormente.

Assim, enquanto, no Fórum, a problemática da profundidade da discussão girou em torno da obrigatoriedade da participação, da falta de motivação para ler os comentários dos colegas e a baixa participação do moderador, no Chat, essa questão parece estar relacionada com a postura imatura de alguns alunos, com a dificuldade para acompanhar a discussão, com o formato de realização da atividade (número grande de participantes e duração) e com o papel do moderador.

O primeiro aspecto que será comentado se refere diretamente ao comportamento do aluno. A partir de uma análise comparativa entre o conteúdo da discussão em diferentes grupos, ficou claro que a falta de seriedade de alguns alunos gerou um impacto negativo na discussão como um todo; de forma que os constantes comentários fora de contexto, como, por exemplo, sobre jogos de futebol, atrapalhavam a leitura das mensagens e resultavam em frustração daqueles que estavam interessados no tema proposto. 
Reforçando essa afirmação, o resultado do teste qui-quadrado indicou, a um nível de significância de $0,2 \%$, associação entre as notas atribuídas pelos alunos em relação à adequação da postura dos colegas no Chat e as notas atribuídas em relação à contribuição dos comentários de colegas para o aprendizado. Dessa forma, o aluno que provavelmente participou das salas de discussão onde os colegas demonstraram menos seriedade com a discussão, percebeu que os comentários dos colegas contribuíram pouco para o aprendizado (67\% dos alunos que atribuíram nota inferior a 6 para a postura dos colegas também atribuíram nota inferior a 6 para a contribuição dos comentários dos colegas). O comportamento imaturo de alguns alunos durante a discussão, possivelmente, influenciou negativamente a discussão como um todo, limitando a contribuição do Chat para o aprendizado dos colegas; a associação entre as notas atribuídas em relação à postura dos colegas e à contribuição do Chat foi identificada, com nível de significância de $0,1 \%$ (Gráfico 18).

Gráfico 18 - Distribuição das Notas Atribuídas pelos Alunos em Relação à Postura dos Colegas, por Avaliação da Contribuição do Chat para o Aprendizado

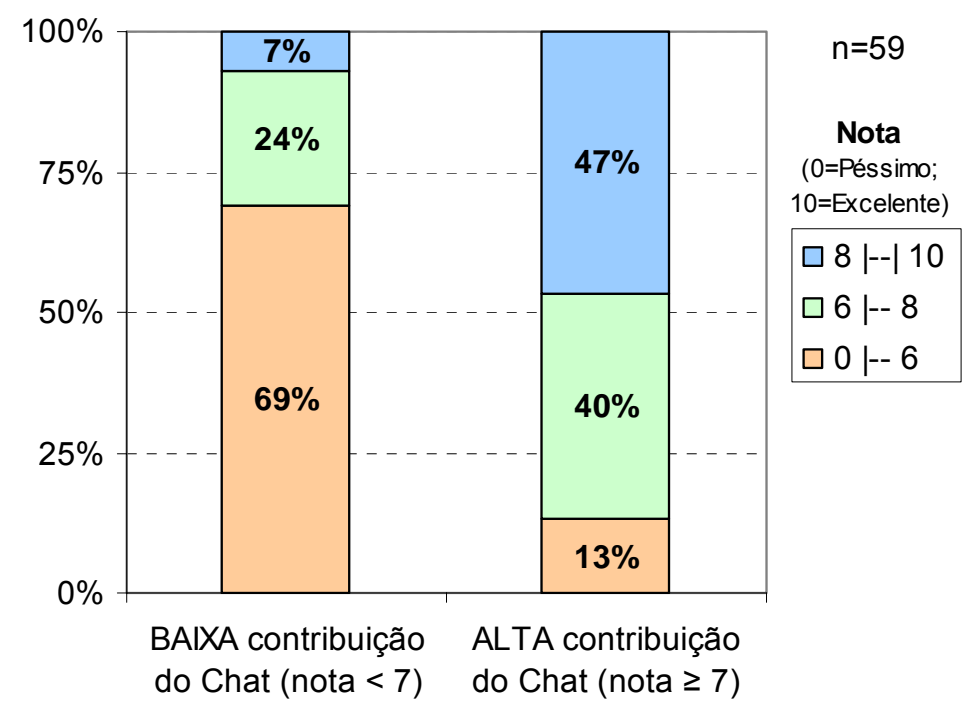

A postura imatura de alguns alunos também foi mencionada pelas professoras. Uma sugestão, mencionada na entrevista, seria discutir a questão do comportamento esperado com maior cuidado antes da discussão. Além disso, poderia ser considerada a adoção de algumas práticas com o objetivo de minimizar esse problema, como a formação dos grupos de discussão com base no nível de interesse e postura em discussões anteriores, a utilização de critérios de avaliação da participação ou até ações mais rigorosas como o bloqueio do sistema. 
A habilidade do aluno para ler e incluir comentários no Chat também pode ter prejudicado seu aproveitamento na atividade, visto que 30\% dos alunos atribuíram notas entre zero e 5 para a existência de dificuldades no acompanhamento e participação das discussões. De acordo com a pesquisa realizada por SORG e McELHINNEY, os participantes do Chat tiveram dificuldades para "acompanhar os vários tópicos sendo discutidos simultaneamente, analisar as novas mensagens e contribuir com comentários importantes", especialmente aqueles com dificuldades na comunicação escrita e na digitação (2000, p. 6, tradução da autora). CHAVES chama a atenção para esse aspecto, quando coloca a participação de alunos com "baixa habilidade de digitação, pouca familiaridade com o ferramental, dificuldade em digitar e simultaneamente ler as mensagens na tela" (2001) como uma das limitações do Chat com fins instrucionais.

Essa questão também pode ter ser analisada em relação aos professores e monitores, que, além de acompanhar o Chat, também precisaram desenvolver habilidades específicas para atuar como moderadores (SPECTOR e LA TEJA, 2001).

Além disso, no primeiro Chat realizado, a dificuldade para acompanhar a discussão foi acentuada devido ao grande número de participantes (20 alunos); o que resultou em comentários sendo incluídos com uma velocidade muito alta, dificultando a leitura e o estabelecimento de uma seqüência na discussão. Esse problema foi minimizado, nas discussões posteriores, através da participação de mais um moderador, possibilitando a realização de discussões em duas salas de Chat simultaneamente com aproximadamente 10 alunos em cada uma.

A definição do número de participantes e duração de cada Chat foi influenciada pelos aspectos operacionais envolvidos na realização da discussão. A primeira questão que foi levantada com os alunos no início do curso foi o melhor horário para realizar o Chat, sendo que poucos alunos afirmaram ter disponibilidade para participar da discussão fora do horário de aula. Se por um lado, a realização da atividade no horário das aulas presenciais garantiu maiores índices de presença, essa escolha também gerou limitações relacionadas a:

- duração do Chat - para acomodar os 60 alunos da turma presencial em uma hora e meia de aula, foi necessário dividir o grupo em três horários de 30 minutos cada um;

- número de moderadores - determinou o número de salas de discussão simultâneas; 
- presença na Faculdade - como vários alunos tinham outra aula logo antes ou depois do Chat, foi necessário participar do laboratório de informática da Faculdade. Apenas alguns alunos aproveitaram a vantagem de não ter que se deslocar até a Faculdade para assistir à aula;

- número de computadores do laboratório - os equipamentos disponíveis foram suficientes na maior parte das vezes.

De acordo com as notas e comentários dos alunos, o número de participantes da discussão poderia ser menor e a duração um pouco maior (notas médias iguais a 6,6 e 6,0, respectivamente), o que implicaria em um formato diferente de realização.

A discussão do formato de realização do Chat também faz-se necessária, tendo em vista as diferentes opiniões dos alunos sobre a substituição das três aulas presenciais por aulas virtuais, para realização da discussão síncrona. A opinião dos alunos sobre esse aspecto, da mesma forma que sobre outras questões relacionadas ao e-learning, variou muito; a seguir, alguns dos comentários dos alunos:

- "Deve-se ressaltar que as atividades de e-learning devem ocorrer de forma COMPLEMENTAR, e nunca substituir a aula presencial";

- “Aulas virtuais com Chat devem ser complemento, o problema é que a maioria não está disponível para fazer Chats em outros horários";

- O que mais gostei foi "poder substituir a aula presencial pela aula virtual. Poupando o tempo e o dinheiro (gasolina) que por sinal é bastante, para vir até a faculdade";

- "Não acho que a turma em geral esteja preparada para substituir as aulas presenciais por aulas virtuais. No meu caso, a dificuldade de acesso foi o maior problema".

No total, 14\% dos 108 respondentes do questionário de avaliação se manifestaram sobre essa questão, sendo a grande maioria dos comentários discordando da substituição da aula presencial. Como resultado dessa divergência de opiniões, a média das notas atribuídas pelos alunos em relação à adequada substituição da aula presencial pela aula virtual (autoestudo, discussão no Fórum e Chat) foi 5,3, com desvio padrão de 3,1.

Interessantemente, a nota atribuída pelos alunos para esse aspecto está associada com a nota atribuída em relação à contribuição do Chat para o aprendizado, a um nível de significância de 1\% (prova qui-quadrado). No Gráfico 19, verifica-se essa tendência dos 
alunos que atribuíram maiores notas para a contribuição do Chat também terem atribuído maiores notas para a adequada substituição da aula presencial pela virtual e vice-versa.

Gráfico 19 - Distribuição das Notas Atribuídas pelos Alunos em Relação à Adequada Substituição da Aula Presencial pela Virtual e à Contribuição do Chat para o Aprendizado

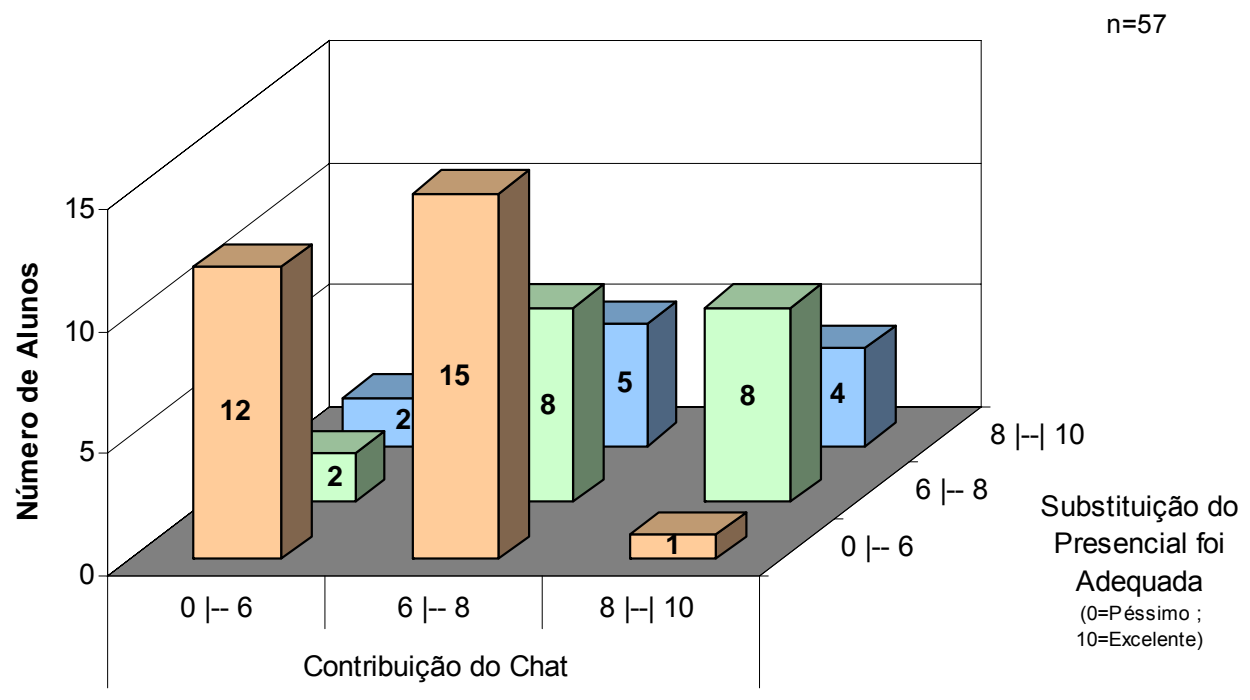

Esse resultado traz de volta o foco da discussão para a contribuição percebida pelos alunos em relação ao Chat. Apesar das limitações discutidas até o momento, a percepção dos alunos sobre a contribuição dessa atividade para o aprendizado também pode ter sido influenciada pelo estilo de aprendizagem dos alunos (a ser comentado posteriormente) e pelos pressupostos existentes em relação ao processo de ensino-aprendizagem. No capítulo dois, foi discutida a necessidade de adoção de uma abordagem centrada no aluno, ao invés daquela mais tradicional, baseada na transmissão de conteúdo pelo professor (LIMA, 2000; CHOU, 2001; CAROLEI, 2002; MOURA, AZEVEDO e MEHLECKE, 2002; REIGELUTH, 1983), a importância da interação no processo de aprendizagem (CHOU, 2001) e o novo papel do professor, como facilitador (BOTELHO, 2002; CAROLEI, 2002; MOURA, AZEVEDO e MEHLECKE, 2002). Os comentários e avaliações de alguns dos alunos participantes desta pesquisa reforçam a dificuldade de o aluno assumir a responsabilidade por sua própria aprendizagem, resultado coerente com a literatura que menciona a manutenção da postura passiva como uma das dificuldades na utilização do e-learning (GODOY, 1997b; PricewaterhouseCoopers, 2001; BRAGA, 2002).

Assim, a preocupação de alguns alunos em relação a essa substituição parece refletir uma supervalorização do conteúdo transmitido pelo professor, mantido no centro do processo 
educativo. Nessa visão, como o objetivo do Chat não é transmitir conteúdos, seu potencial para a aprendizagem pode parecer muito limitado. Dessa forma, a expectativa de alguns alunos, que esperam uma dinâmica semelhante àquela estabelecida em sala de aula, não é atendida; situação refletida nessa discussão sobre a substituição da aula presencial e em alguns comentários, como este: “Discussões permeadas por 'achismos' que não representaram real conteúdo. Falta controle do supervisor de forma a guiar o tema". No comentário de outro aluno, a participação diferenciada do professor é mencionada: "Me parece que os alunos em geral mostraram um pouco de desinteresse com relação ao e-learning. Senti isso também da minha parte. Talvez pelo fato de os professores terem sido menos participativos em relação a uma aula em sala de aula".

Novas opções tecnológicas, como o uso de vídeo e voz, podem tornar o Chat mais próximo da relação estabelecida na sala de aula; mas, por outro lado, considerando que esta pesquisa justamente discute a possibilidade de enriquecer o processo de ensino-aprendizagem através da utilização de diversas técnicas, parece mais interessante poder criar diferentes dinâmicas, ao invés de tentar se aproximar ao modelo do ensino presencial.

Além disso, é importante ter em mente as diferenças nos estilos de aprendizagem dos alunos, que resulta em discordâncias quanto às melhores atividades e métodos de ensino. Dessa forma, os alunos dificilmente chegariam a um consenso sobre a importância do Chat em relação ao presencial.

A conexão entre o tema da discussão e o conteúdo das aulas presenciais também foi analisada através das duas opções realizadas: (1) foi proposto um texto para leitura e discussão no Chat, tema que seria posteriormente abordado durante a aula presencial; (2) a discussão no Chat foi realizada após a aula presencial sobre o assunto. O segundo modelo pareceu ser mais produtivo para os alunos, tendo sido registrado em alguns comentários dos alunos:

- "Agendar o Chat após a aula presencial, acho que, assim, os comentários seriam mais relevantes";

- "Creio que é indispensável que o assunto do Chat já tenha sido transmitido durante a aula; de maneira que no Chat seja feita uma revisão dirigida do que foi visto em aula";

Do ponto de vista do professor, enquanto a realização da aula teórica antes da discussão possibilita uma participação maior dos alunos, a ordem inversa permite identificar 
conhecimentos prévios e criar interesse pelo tema. Assim, a abordagem a ser adotada deve estar coerente com os objetivos de aprendizagem propostos.

A atividade WebQuest realizada após a aula teórica sobre o tema e antes do Chat, também pareceu ser uma boa prática, visto que envolveu um maior conteúdo teórico, sua aplicação em um caso prático e a discussão em pequenos grupos. Assim, os alunos se interessaram mais pela discussão realizada após essa atividade, conforme mencionado por um dos alunos: "Foi o melhor chat do semestre, pois todos estavam engajados e empenhados em discutir o assunto".

Durante o andamento da disciplina, observou-se uma crescente melhoria nas aulas virtuais realizadas, tanto no formato das atividades propostas quanto na atuação dos alunos e moderadores.

Dessa forma, é preciso levar em conta que os alunos, professores e monitores precisam de tempo para se familiarizem com a tecnologia e pedagogia envolvidas no e-learning. BROWN (2001) ilustra esta questão quando menciona os triângulos do tempo, onde o aluno iniciante despende muito tempo para se familiarizar com a tecnologia e o método de ensino, sobrando menos tempo para realizar atividades relacionadas ao conteúdo e à interatividade (formação da comunidade); o inverso se aplica ao aluno experiente (Figura 17). De acordo com o autor, a classificação entre iniciante e experiente baseia-se em fatores como personalidade, tempo, interação e, possivelmente, participação e envolvimento.

Figura 17 - Triângulos do Tempo

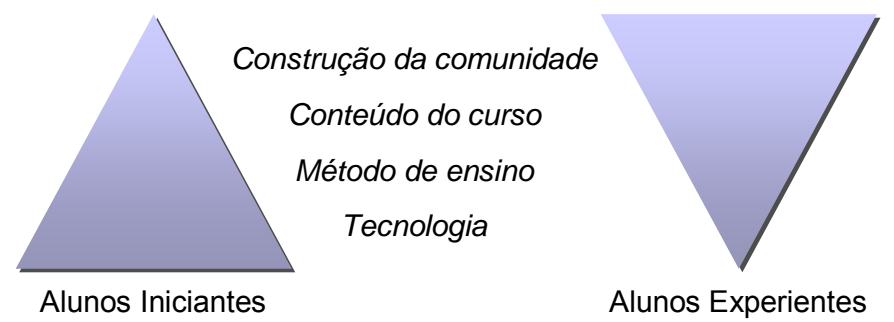

Fonte: BROWN (2001, p. 26, tradução e cores da autora).

A evolução nas discussões realizadas no Chat também foi mencionada pelos alunos através dos comentários enviados ao Fórum sobre cada uma das discussões realizadas (Quadro 21), incluindo aspectos como: necessidade de se familiarizar com a atividade; organização e número de participantes; manutenção do foco da discussão; papel dos moderadores. 
Quadro 21 - Comentários dos Alunos sobre as Melhorias no Chat

\begin{tabular}{|l|l|}
\hline $1^{\circ}$ Chat & $\begin{array}{l}\text { Comentários dos alunos sobre a discussão no Chat } \\
\text { "Mas para uma primeira experiência de aula virtual, até que deu resultado. } \\
\text { Espero que possamos nos aprimorar nesse método de ensino, pois ele parece ser } \\
\text { bem eficaz"; } \\
\text { "Acho que por não estarmos acostumados tivemos dificuldades, mas } \\
\text { possivelmente nos acostumaremos melhor nas próximas experiências". }\end{array}$ \\
\hline $2^{\circ}$ Chat & $\begin{array}{l}\text { "A discussão foi muito mais organizada e enriquecedora, pois o foco da } \\
\text { discussão estava claro e foi mantido nas discussões"; } \\
\text { "Gostei do 20 Chat, achei que as pessoas participaram mais, e se mostraram } \\
\text { mais familiarizadas com esse tipo de material didático"; } \\
\text { "Achei que no segundo Chat, obtive um aproveitamento melhor que no } \\
\text { primeiro, pois a classe se mostrou um pouco mais organizada e a discussão } \\
\text { ocorreu com maior fluidez. Espero o próximo!"; } \\
\text { "Foi melhor que o primeiro devido ao número de pessoas que participaram da } \\
\text { discussão"; } \\
\text { "[... por estarmos mais familiarizados com o Chat e por termos avançado mais } \\
\text { na matéria, pudemos nos concentrar em temas relevantes e pertinentes ao } \\
\text { propósito da aula". }\end{array}$ \\
\hline $3^{\circ}$ Chat & $\begin{array}{l}\text { "Na minha opinião, o e-learning na nossa turma apresentou um constante } \\
\text { aperfeiçoamento ao longo do semestre"; } \\
\text { "A participação dos moderadores está cada vez melhor e a discussão como um } \\
\text { todo". }\end{array}$ \\
\hline
\end{tabular}

Essa mesma tendência também parece se aplicar ao Fórum, embora nesta pesquisa esta evolução não tenha sido observada. É possível que o uso limitado não tenha possibilitado que os alunos se acostumassem com a ferramenta a ponto de resultar em melhores discussões.

Com o objetivo de sintetizar os principais aspectos discutidos neste tópico, a Figura 18 apresenta, no formato esquemático de causa e efeito, as possíveis explicações do resultado obtido em relação à contribuição do Chat para o aprendizado do aluno. 
Figura 18 - Resumo das Possíveis Relações Explicativas da Contribuição do Chat para o Aprendizado do Aluno

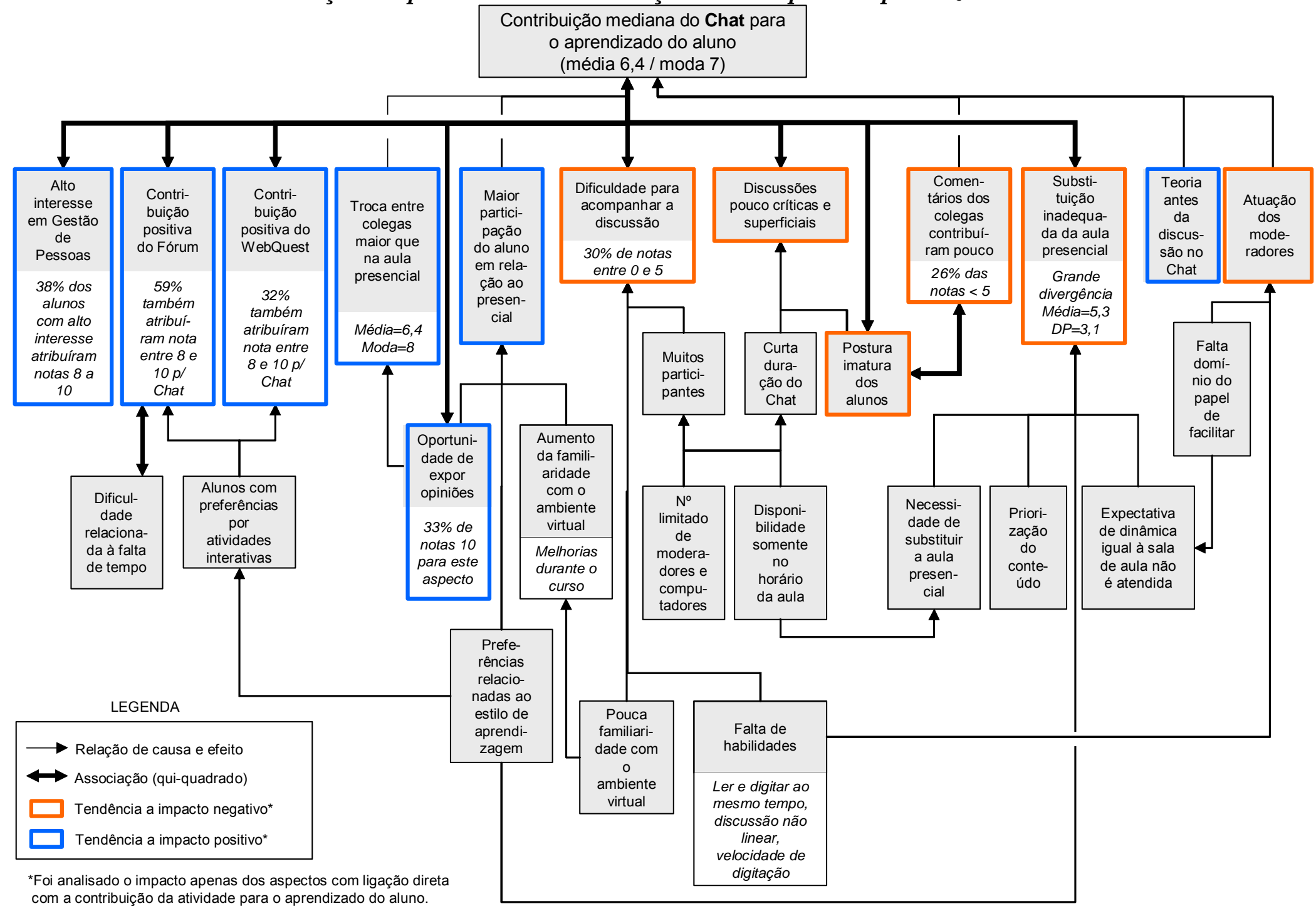




\subsubsection{Satisfação geral em relação ao e-learning}

De acordo com a percepção dos alunos, as atividades de e-learning que mais contribuíram para o aprendizado foram os testes auto-corrigidos e o WebQuest, considerando que $52 \%$ e $62 \%$ dos respondentes, respectivamente, atribuíram notas altas (de 8 a 10) para esses aspectos (Gráfico 20). Por outro lado, a contribuição do Fórum para o aprendizado foi o indicador que mais recebeu notas baixas (11\% das notas estão entre zero e 2), resultado já discutido em tópico anterior.

Gráfico 20 - Distribuição das Notas Atribuídas pelos Alunos para a Contribuição de Cada Atividade de e-Learning no Aprendizado

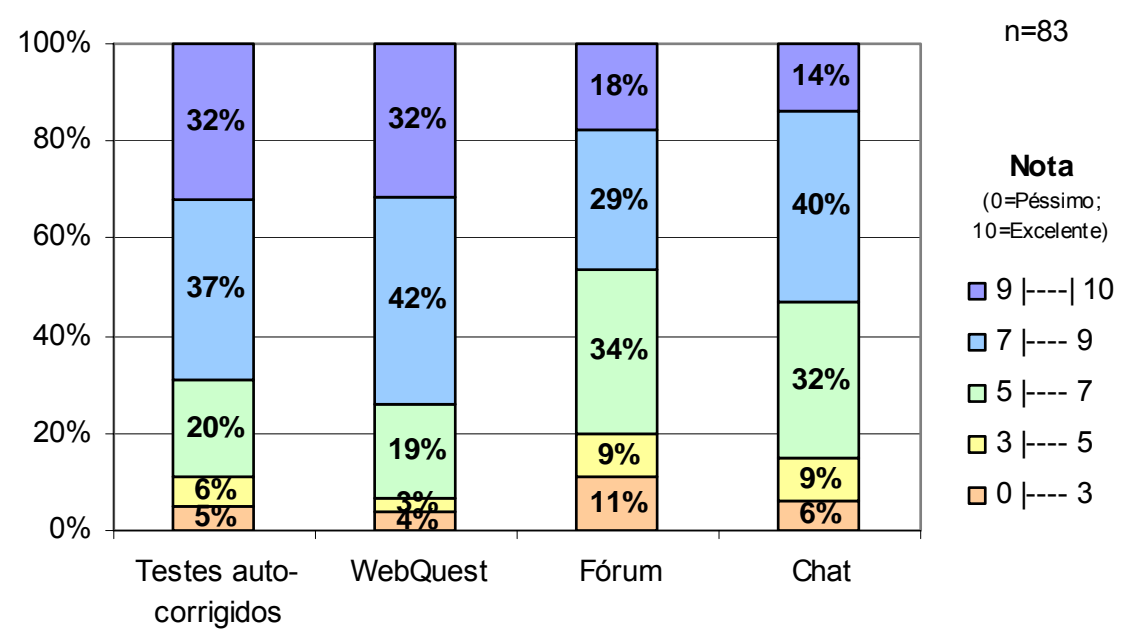

Ao analisar as respostas sobre o que os alunos mais gostaram e menos gostaram na experiência de e-learning (questão aberta), a discussão no Chat foi um dos aspectos mais comentados e, claramente, motivo de maior divergência (Gráfico 21): 24 alunos (22\% dos respondentes) mencionaram esse aspecto como o de que mais gostaram e 25 alunos (23\% dos respondentes) como o que de menos gostaram. Esse resultado reforça a análise mais detalhada sobre essa discordância apresentada no tópico anterior.

Os testes auto-corrigidos também foram motivo de divergência, embora em grau muito menor: 7 alunos mencionaram essa atividade como a de que mais gostaram e 2 alunos mencionaram como a de que menos gostaram.

Os outros aspectos bastante mencionados dentre aqueles mais apreciados foram: a utilização de uma nova metodologia de ensino; o uso de um ambiente virtual, do computador 
e de um novo software; a flexibilidade para realizar as atividades (horário, deslocamento e acesso); o caráter de inovação da experiência; a facilidade para aprender e a oportunidade de aprofundamento na matéria; a discussão no Fórum.

Dentre os aspectos de que os alunos menos gostaram, os mais citados foram: a aula virtual, no que se refere à falta de instruções, impessoalidade, obrigação de acesso e necessidade de melhorias; a postura dos alunos no Chat; as dificuldades encontradas para acompanhar o Chat; a substituição da aula presencial pela virtual; o excesso de atividades propostas; as dificuldades tecnológicas (dúvidas de navegação, problemas no acesso ao WebCT e recursos limitados do computador); a dificuldade relacionada à falta de tempo para realização das atividades propostas; curta duração do Chat.

Gráfico 21 - Distribuição das Respostas Atribuídas pelos Alunos sobre o Aspecto de que Mais Gostaram e o de que Menos Gostaram na Experiência com o e-Learning

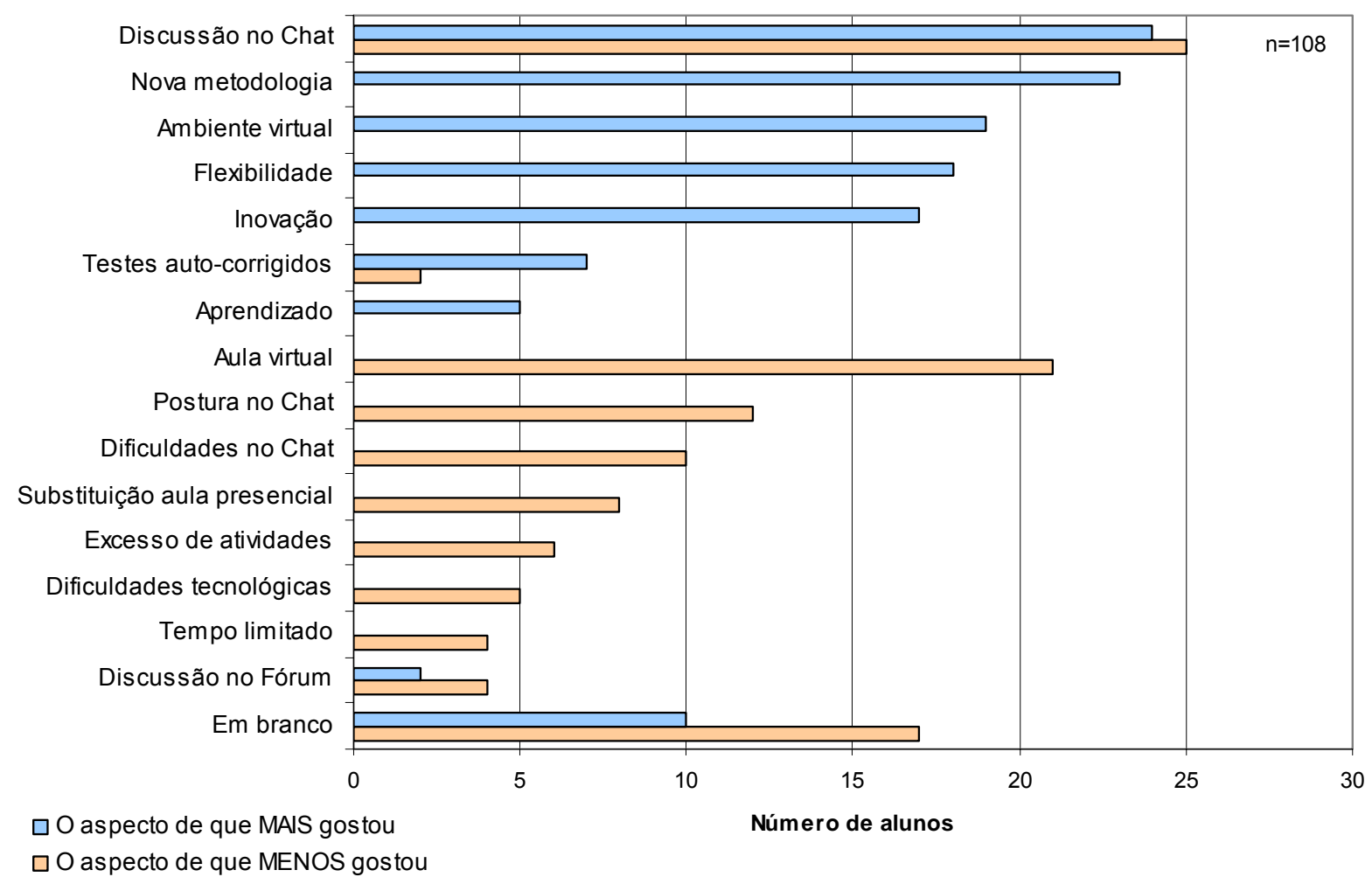

No geral, a percepção dos alunos em relação à contribuição geral do e-learning para o aprendizado foi positiva (moda igual a 7), embora os $8 \%$ de notas abaixo de 5 reforcem a necessidade de aprimoramento das atividades (Gráfico 22). 
Gráfico 22 - Distribuição das Notas Atribuídas pelos Alunos em relação à Contribuição Geral das Atividades de e-Learning para o Aprendizado

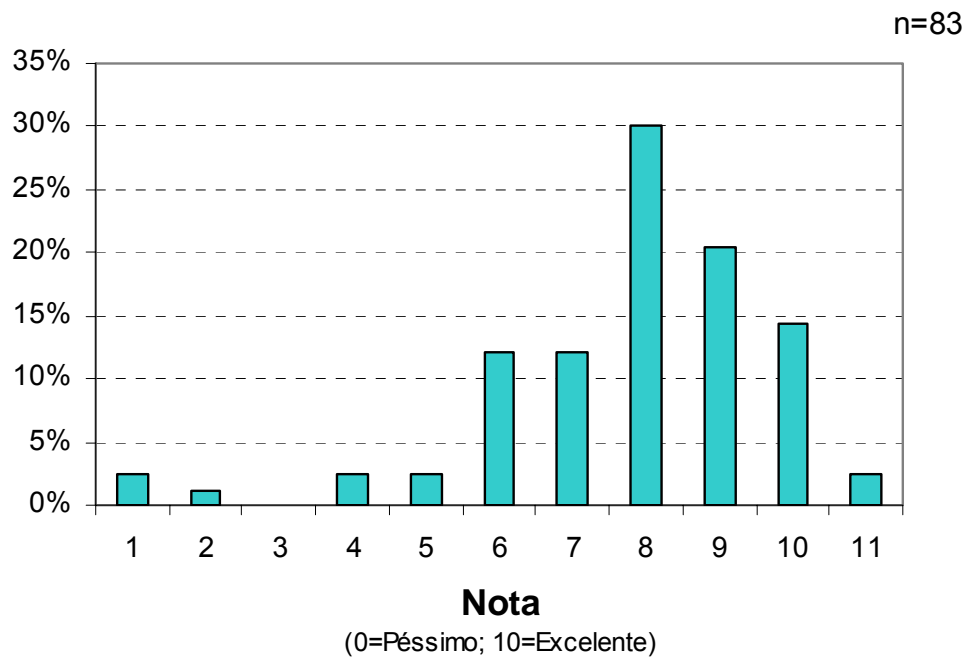

Embora a percepção dos alunos em relação à contribuição do e-learning para o aprendizado tenha sido positiva, não foi verificada uma associação estatisticamente significativa entre as notas das provas e a média final da disciplina e as notas atribuídas para esse aspecto (prova qui-quadrado). Apesar disso, os dados indicam uma leve tendência de os alunos que atribuíram notas mais altas para a contribuição das atividades de $e$-learning, terem tirado notas mais altas na disciplina (Tabela 6). Esse resultado está coerente com a pesquisa de ARBAUGH (2000), em que os alunos, em geral, tiveram uma percepção justa quanto ao nível de aprendizado obtido.

Tabela 6 - Média e Desvio Padrão das Notas na Disciplina, por Nota Atribuída em Relação à Contribuição das Atividades de e-Learning para o Aprendizado

\begin{tabular}{|c|c|c|c|c|c|c|c|c|c|c|c|}
\hline \multirow{3}{*}{$\begin{array}{l}\text { NOTA na } \\
\text { disciplina }\end{array}$} & & \multicolumn{10}{|c|}{ Contribuição da atividade de e-learning para o aprendizado do aluno } \\
\hline & & \multicolumn{2}{|c|}{$\begin{array}{l}\text { Teste auto- } \\
\text { corrigido }\end{array}$} & \multicolumn{2}{|c|}{ WebQuest } & \multicolumn{2}{|c|}{ Fórum } & \multicolumn{2}{|c|}{ Chat } & \multicolumn{2}{|c|}{$\begin{array}{c}\text { Geral do } \\
\text { e-learning }\end{array}$} \\
\hline & & $\begin{array}{c}<8 \\
(\mathrm{n}=28)\end{array}$ & $\begin{array}{c}\geq 8 \\
(\mathrm{n}=31)\end{array}$ & $\begin{array}{c}<8 \\
(\mathrm{n}=21) \\
\end{array}$ & $\begin{array}{c}\geq 8 \\
(n=32)\end{array}$ & $\begin{array}{c}<7 \\
(n=35)\end{array}$ & $\begin{array}{c}\geq 7 \\
(\mathrm{n}=24)\end{array}$ & $\begin{array}{c}<7 \\
(n=29) \\
\end{array}$ & $\begin{array}{c}\geq 7 \\
(n=30)\end{array}$ & $\begin{array}{c}<8 \\
(\mathrm{n}=40)\end{array}$ & $\begin{array}{c}\geq 8 \\
(\mathrm{n}=21)\end{array}$ \\
\hline \multirow[t]{2}{*}{ Participação } & Média & 7,7 & 7,9 & 7,3 & 8,3 & 7,9 & 7,9 & 7,8 & 8,0 & 7,6 & 8,1 \\
\hline & $D P$ & 1,7 & 1,2 & 1,5 & 1,4 & 1,5 & 1,2 & 1,5 & 1,2 & 1,6 & 1,4 \\
\hline \multirow[t]{2}{*}{$1^{\text {a }}$ Prova } & Média & 9,0 & 9,0 & 8,9 & 9,0 & 9,1 & 8,9 & 9,0 & 9,0 & 8,9 & 9,1 \\
\hline & $D P$ & 0,7 & 0,5 & 0,6 & 0,6 & 0,5 & 0,7 & 0,7 & 0,5 & 0,7 & 0,5 \\
\hline \multirow[t]{2}{*}{$2^{a}$ Prova } & Média & 8,7 & 9,0 & 8,7 & 8,9 & 8,9 & 8,7 & 8,7 & 8,9 & 8,8 & 8,9 \\
\hline & $D P$ & 0,8 & 0,6 & 0,7 & 0,7 & 0,7 & 0,6 & 0,7 & 0,6 & 0,7 & 0,7 \\
\hline \multirow{2}{*}{$\begin{array}{l}\text { Trabalho } \\
\text { Final }\end{array}$} & Média & 9,2 & 9,1 & 9,1 & 9,2 & 9,2 & 9,2 & 9,1 & 9,3 & 9,1 & 9,2 \\
\hline & $D P$ & 0,7 & 0,8 & 0,9 & 0,8 & 0,7 & 0,7 & 0,8 & 0,7 & 0,8 & 0,7 \\
\hline \multirow[t]{2}{*}{ Média Final } & Média & 8,5 & 8,8 & 8,5 & 8,8 & 8,6 & 8,7 & 8,5 & 8,8 & 8,6 & 8,6 \\
\hline & $D P$ & 1,3 & 0,5 & 0,6 & 0,6 & 1,1 & 0,5 & 1,2 & 0,5 & 0,7 & 1,4 \\
\hline
\end{tabular}

*Nota: $0=$ Péssimo e $10=$ Excelente 
É importante lembrar as limitações envolvidas na análise das notas dos alunos, tendo em vista os diversos fatores que podem ter influenciado este resultado. Além disso, as atividades de e-learning representaram uma parte pequena das atividades da disciplina pesquisada, que foi essencialmente presencial.

A mesma tendência, indicando uma contribuição positiva do e-learning para o aprendizado, é observada na comparação da nota final média dos alunos aprovados na disciplina pesquisada $(\mathrm{n}=115)$ com a nota final média dos alunos aprovados de outra turma da disciplina Administração de RH I (Tabela 7), apesar das grandes limitações envolvidas nessa comparação. Com o objetivo de manter alguns aspectos constantes, foi escolhida uma turma de alunos do período diurno para a qual a Prof ${ }^{\mathrm{a}}$. $\operatorname{Dr}^{\mathrm{a}}$. Ana Cristina Limongi França ministrou a mesma disciplina (primeiro semestre de 2001) e também foi responsável pela correção das provas e atribuição das notas. Os resultados mostram que a média da nota final dos alunos aprovados, em 2002, é um pouco superior ao valor referente aos alunos aprovados em 2001, diferença ainda maior se for considerada a média da nota final dos alunos com alta participação online. Esse resultado reforça a possibilidade do $e$-learning ter contribuído para o aprendizado da matéria, principalmente no caso dos alunos que se envolveram mais com as atividades.

Tabela 7 - Média e Desvio Padrão da Nota Final dos Alunos Aprovados na Disciplina Administração de RH I (Diurno), por Período de Realização e por Nível de Participação Online*

\begin{tabular}{lcc}
\hline Turma & Média & DP \\
\hline Alunos do $1^{\circ}$ Sem./2001 $(\mathrm{n}=59)$ & 8,21 & 0,73 \\
Alunos do $2^{\circ} \mathrm{Sem} . / 2002(\mathrm{n}=115)$ & 8,36 & 0,78 \\
\hline Alunos do $2^{\circ}$ Sem./2002 com BAIXA participação online* $(\mathrm{n}=68)$ & 8,11 & 0,71 \\
Alunos do $2^{\circ}$ Sem./2002 com ALTA participação online* $(\mathrm{n}=47)$ & 8,73 & 0,74 \\
\hline
\end{tabular}

*Critérios para cálculo da participação online: numero de Hits $\geq 100$; mensagens enviadas $\geq 4$; mensagens lidas $\geq 20$

Baixa participação online: nenhum ou somente um dos critérios é atendido

Alta participação online: pelo menos dois dos critérios são atendidos

Coerente com estas análises e confirmando os resultados de outras pesquisas (REINHARD, YONEZAWA e MORGADO, 2000; FREDERICKSEN et al., 2000), foi identificada uma associação entre a percepção do aluno em relação à contribuição do $e$ learning para o aprendizado e seu nível de participação online, a um nível de significância de $10 \%$ (prova qui-quadrado); ou seja, os alunos que menos participaram também perceberam 
uma menor contribuição do e-learning, visto que atribuíram mais notas inferiores a 6 para esse aspecto (Gráfico 23). A participação online foi calculada a partir do número de vezes que o aluno acessou a Homepage, atividades, ferramentas de comunicação e materiais no WebCT (número de Hits) e do nível de participação no Fórum (mensagens lidas e enviadas).

\section{Gráfico 23 - Distribuição das Notas Atribuídas pelo Alunos em Relação à Contribuição Geral do e-Learning para o Aprendizado, por Nível de Participação Online*}

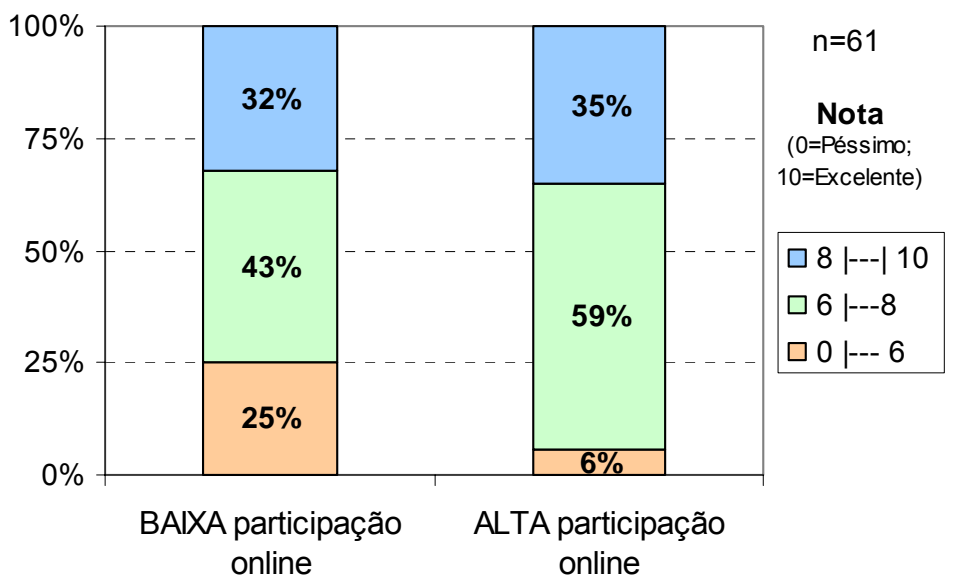

*Critérios para cálculo da participação online: numero de Hits $\geq 100$; mensagens enviadas $\geq 4$; mensagens lidas $\geq 20$

Baixa participação online: nenhum ou somente um dos critérios é atendido Alta participação online: pelo menos dois dos critérios são atendidos

Uma associação semelhante foi identificada em relação ao conteúdo do curso Abril/FIA, acessado pelos alunos, a um nível de significância de $10 \%$; sendo que $52 \%$ dos alunos com maior acesso (número de Hits $\geq 10$ ) atribuíram nota entre 8 e 10 em relação à contribuição do e-learning para o aprendizado, enquanto apenas $13 \%$ dos alunos com menor participação atribuíram notas na mesma faixa.

Ainda em relação à contribuição geral do e-learning para o aprendizado, o teste quiquadrado indicou a associação dessa variável com a motivação percebida pelo aluno para realizar um bom trabalho, com nível de significância de 1\%; ou seja, $65 \%$ dos alunos que atribuíram nota 9 ou 10 para seu nível de motivação também atribuíram nota 9 ou 10 em relação à contribuição geral do e-learning para o aprendizado (Gráfico 24). 


\section{Gráfico 24 - Distribuição das Notas Atribuídas pelos Alunos em Relação à Contribuição do e-Learning para o Aprendizado e ao Nível de Motivação}

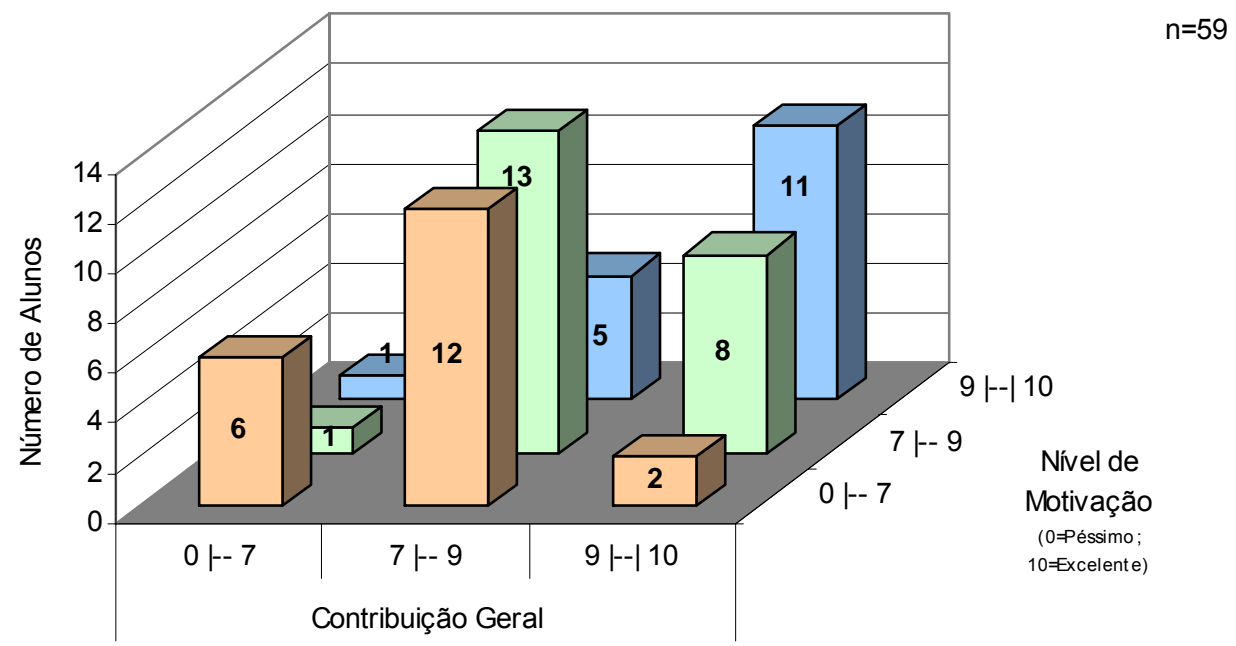

Dessa forma, é possível que os alunos mais motivados aproveitaram melhor as atividades de e-learning para aprender mais. Buscando identificar possíveis aspectos que influenciam essa motivação percebida pelos alunos, o teste qui-quadrado foi aplicado relacionando a motivação do aluno para realizar um bom trabalho e os demais indicadores de perfil e aproveitamento do curso, o que resultou em quatro associações:

- Incidência de dificuldade relacionada a recursos tecnológicos insuficientes (nível de significância igual a 10\%): dos 4 alunos que mencionaram essa dificuldade, 3 deles atribuíram uma nota menor que sete para seu nível de motivação;

- Incidência de dificuldade relacionada à falta de tempo (nível de significância igual a 2\%): $60 \%$ do total de alunos que atribuíram nota inferior a 7 para o nível de motivação $(n=20)$ mencionaram que tiveram dificuldade com a falta de tempo ${ }^{29}$;

- Nível de participação online $e^{30}$ (nível de significância igual a 10\%): 63\% dos alunos que atribuíram nota inferior a 7 para o nível de motivação tiveram baixa participação nas atividades online;

\footnotetext{
${ }^{29}$ Da mesma forma que apresentado anteriormente no Gráfico 14, se o nível de participação for considerado nesta análise, é possível identificar, no grupo de alunos que sentiram falta de tempo, que a maioria que atribuiu notas baixas para o nível de motivação $(<7)$ teve baixa participação online; ou seja, dos 12 alunos que atribuíram notas baixas para a motivação, 8 tiveram baixa participação.

$30 *$ Critérios para cálculo da participação online: numero de Hits $\geq 100$; mensagens enviadas $\geq 4$; mensagens lidas $\geq 20$ / Baixa participação online: nenhum ou somente um dos critérios é atendido / Alta participação online: pelo menos dois dos critérios são atendidos.
} 
- Nível de participação no Fórum (nível de significância igual a 5\%): 50\% dos alunos que atribuíram nota inferior a 7 para o nível de motivação tiveram baixa participação no Fórum ( $\mathrm{n}^{\mathrm{o}}$ de mensagens enviadas $<4$ e $\mathrm{n}^{\mathrm{o}}$ mensagens lidas $<20$ ).

Esse resultado está coerente com as possíveis causas da baixa motivação ou até frustração, apresentados na literatura. De acordo com o estudo realizado por HARA e KLING (1999), uma das principais fontes de frustração dos alunos foi a incidência de problemas tecnológicos. A percepção da falta de tempo como uma dificuldade que impacta no nível de motivação pode ser conseqüência de um sentimento de sobrecarga relacionado à comunicação virtual, mencionado por MURRAY e MASON (2003) e LANDIS (2001) e já discutido anteriormente.

A relação entre a motivação e o nível de participação foi mencionado por VASCONCELLOS e BERGAMASCHI (2001), que analisaram a baixa participação como uma possível conseqüência da frustração (Figura 8 apresentada no capítulo dois). Essa associação está coerente com a relação já comentada entre as notas atribuídas em relação à contribuição geral do e-learning e o nível de participação online (Gráfico 23).

Também foram identificadas associações da contribuição geral do e-learning para 0 aprendizado com as notas atribuídas em relação à contribuição dos testes auto-corrigidos e em relação à contribuição do WebQuest para o aprendizado, a um nível de significância de $10 \% \mathrm{e}$ $1 \%$, respectivamente. Dessa forma, os alunos que atribuíram notas altas para a contribuição dessas duas atividades, atribuíram notas mais altas para a contribuição geral do e-learning (Gráfico 25). Esse resultado é coerente, visto que, de acordo com a percepção dos alunos, os testes auto-corrigidos e o WebQuest foram as atividades que mais contribuíram para o aprendizado, se comparadas às demais (Gráfico 20, já apresentado).

\section{Gráfico 25 - Distribuição das Notas Atribuídas pelos Alunos em Relação à Contribuição Geral do e-Learning e das Notas em Relação à Contribuição dos Testes Auto-corrigidos e do WebQuest}
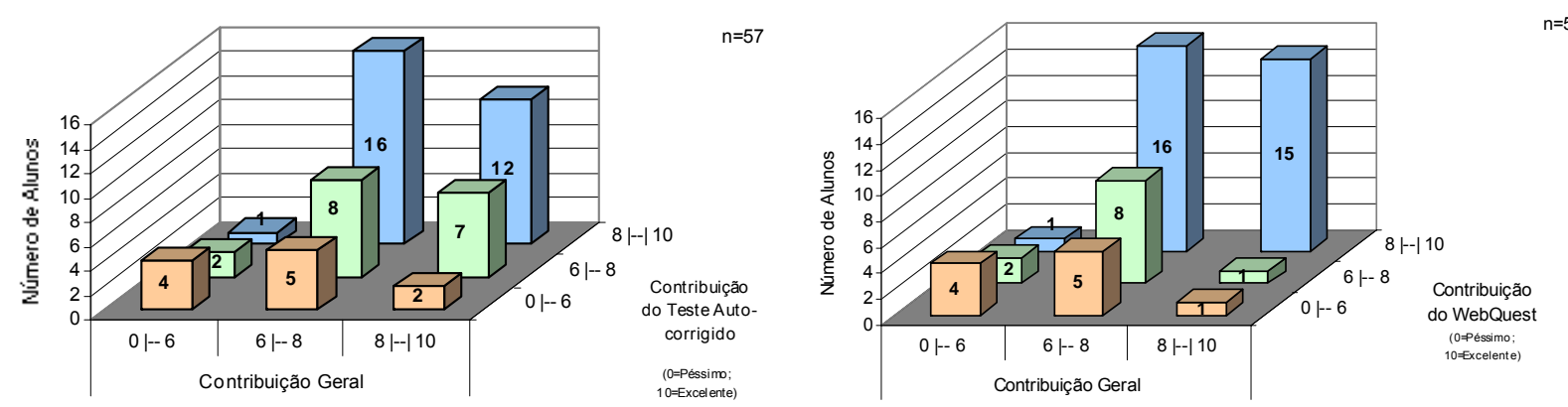
Um benefício do e-learning, não muito citado na literatura e verificado nos resultados desta pesquisa, é o aumento do interesse de alguns alunos no tema do curso, decorrente das atividades virtuais, considerando que $28 \%$ dos alunos atribuíram notas entre 8 e 10 para esse aspecto. De acordo com os resultados, $56 \%$ dos alunos que perceberam um aumento do interesse em gestão de pessoas decorrente das atividades de e-learning atribuíram notas entre 7 e 10 para a contribuição do e-learning (associação com nível de significância igual a 2\%).

É interessante notar que desses alunos que atribuíram notas entre 8 e 10 para o aumento do interesse $(\mathrm{n}=18), 11$ alunos já possuíam um alto interesse em Gestão de Pessoas e os outros 7 tinham um interesse médio ou baixo pelo tema, relação verificada ao nível de significância de $2 \%$ (teste qui-quadrado). Diferentemente do que se esperava, o teste quiquadrado não indicou associação significativa entre o aumento do interesse e as preferências individuais dos alunos (estilo de aprendizagem).

Semelhante ao resultado já comentado em relação ao Chat, foi verificada uma associação entre a adequada substituição da aula presencial pela virtual e a contribuição percebida do e-learning para o aprendizado, a um nível de significância de 5\%; ou seja, 27\% dos alunos que perceberam como inadequada a substituição (nota menor que 5) também perceberam que a contribuição do e-learning não foi positiva (nota menor que 5). Essa associação reforça a importância de se incentivar uma cultura de auto-aprendizagem, em que o aluno assuma a responsabilidade por seu aprendizado, ao invés de deixar esse papel exclusivamente para o professor.

Complementando esta análise, outro aspecto a ser considerado na compreensão da opinião dos alunos que acharam a substituição da aula presencial pela virtual inadequada, seria uma certa atitude contestadora, ou seja, fica a dúvida se esses alunos realmente valorizam a aula presencial ou se eles estavam mais preocupados em criticar o novo método utilizado, que representou apenas $10 \%$ da disciplina, enquanto a legislação permite a utilização de atividades não presenciais em até $20 \%$ do curso (BRASIL, 2001).

Na média, podemos considerar que as atividades de $e$-learning realizadas atenderam às expectativas dos alunos, visto que a nota média desse indicador é 7 e $36 \%$ das notas estão entre 8 e 10 (Gráfico 26). Além disso, um dos alunos registrou o seguinte comentário: "Experiência interessante. Esse sistema de aulas virtuais superou minhas expectativas". Por outro lado, os dados indicam a existência de muito espaço para aprimoramento. 
Gráfico 26 - Distribuição das Notas Atribuídas pelos Alunos para o Atendimento das Expectativas em Relação às Atividades Realizadas e o Nível de Interesse em Participar de Outra Disciplina com Atividades de e-Learning

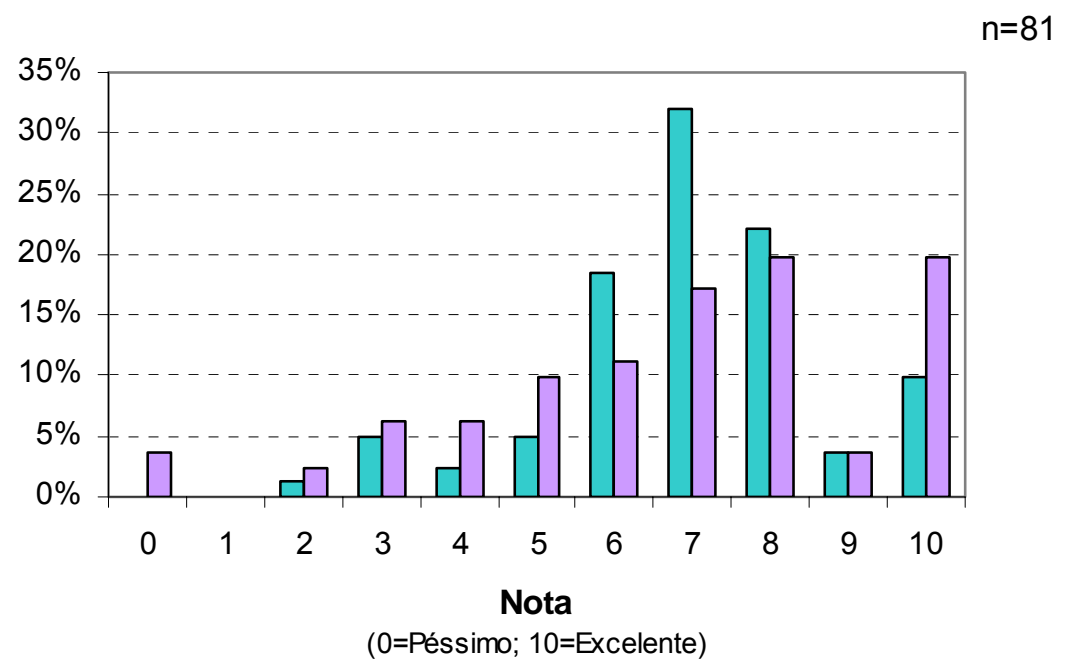

$\square$ Atendimento às expectativas $\square$ Faria outra disciplina com e-learning

Quanto ao interesse dos alunos em participar de outra disciplina com atividades de $e$ learning as opiniões foram mais divergentes, aspecto que pode ser verificado na comparação dos resultados apresentados na Tabela 2 e no Gráfico 26. Mesmo assim, na média o resultado é positivo (média igual a 6,7), além das notas com maior freqüência serem 8 e 10.

Com o objetivo de sintetizar os principais aspectos discutidos neste tópico, a Figura 19 apresenta, no formato esquemático de causa e efeito, as possíveis explicações do resultado obtido em relação à contribuição geral do e-learning para o aprendizado do aluno. 
Figura 19 - Resumo das Possíveis Relações Explicativas da Contribuição do e-Learning para o Aprendizado do Aluno

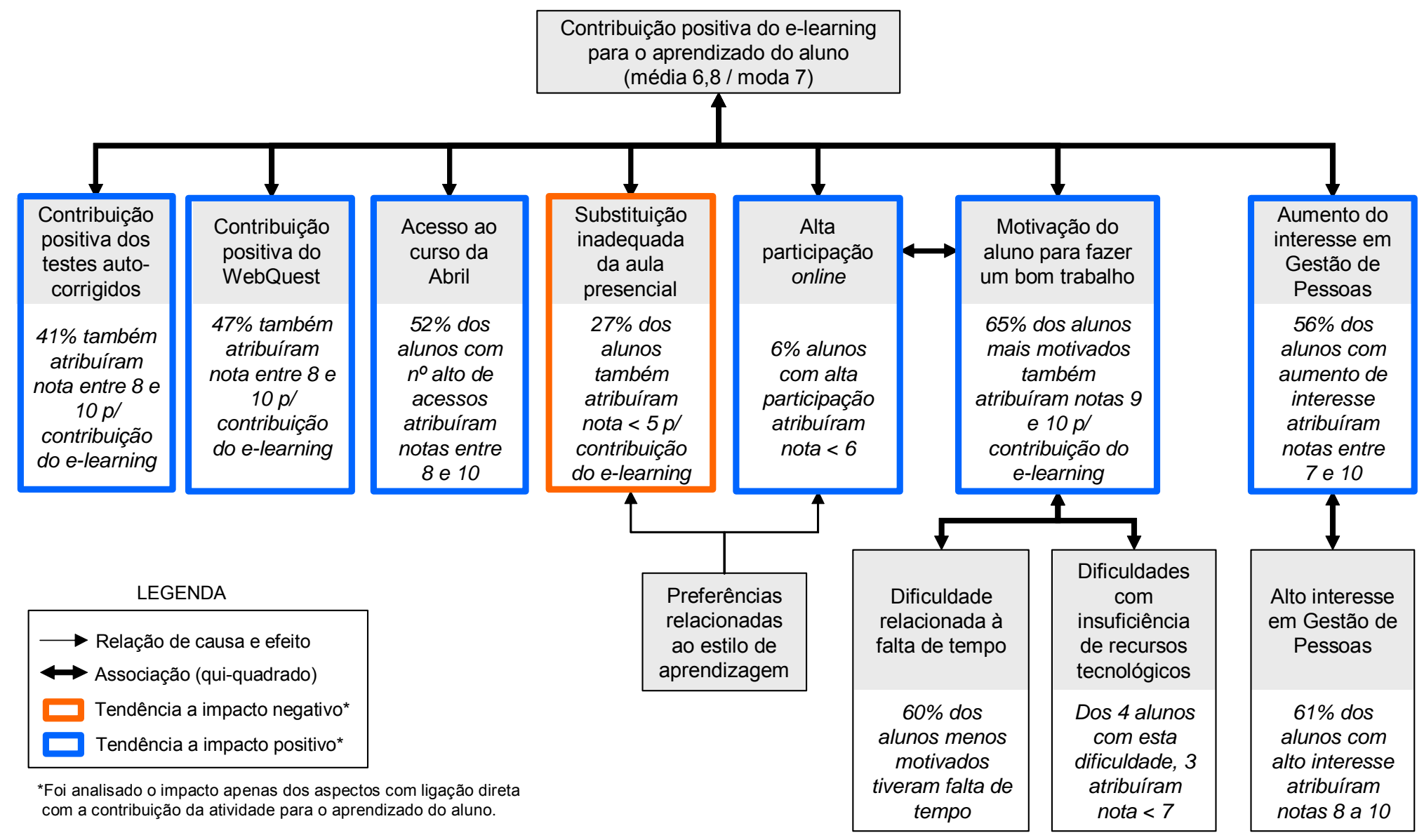


Dentre os principais resultados relacionados à contribuição das atividades e do $e$ learning como um todo para o aprendizado da matéria pelo aluno, é possível citar:

- A possibilidade de os alunos com maior interesse aproveitarem os materiais disponibilizados para se aprofundar na matéria;

- A contribuição dos testes auto-corrigidos no estímulo à leitura dos textos e no auxílio para a compreensão e revisão dos conteúdos;

- A contribuição do WebQuest na aplicação dos conceitos a um caso prático, de forma colaborativa, resultando em trabalhos que foram além da teoria discutida em classe;

- A oportunidade de exposição de opiniões e maior participação dos alunos através do Fórum e Chat, aspecto muito valorizado por alunos com determinados estilos de aprendizagem;

- A oportunidade para aprendizado através da leitura de mensagens do Fórum;

- A necessidade de aprofundar as discussões realizadas no Fórum e no Chat, tornandoas mais críticas, restringindo a contribuição dessas atividades para o aprendizado;

- Os aspectos que limitaram a discussão no Fórum, como o caráter obrigatório da atividade, a baixa motivação para leitura e semelhança entre os comentários dos colegas, o tempo necessário para gerenciar as mensagens, a dificuldade de alguns alunos relacionada à falta de tempo e a baixa participação dos moderadores;

- Os aspectos que limitaram as discussões no Chat, como dificuldades para acompanhar a discussão (de alunos e professores), a falta de familiaridade com o ambiente virtual, a postura imatura de alguns alunos, a duração muito curta da discussão, o excesso de participantes e a necessidade de aprimoramento das habilidades dos moderadores;

- A melhoria observada nas aulas virtuais, reforçando a necessidade de considerar o tempo de familiarização com o ambiente de discussão;

- A influência do nível de interesse em gestão de pessoas e da sobrecarga e falta de tempo nos resultados atingidos;

- A discussão sobre a substituição da aula presencial pela virtual, que pode ser relacionada à postura do aluno perante seu processo de aprendizagem; 
- A relação entre a contribuição do e-learning e o nível de motivação percebido, que também está associado com o nível de participação online e a incidência de dificuldades (falta de tempo e insuficiência de recursos tecnológicos);

- A tendência de os alunos que perceberam maior contribuição do e-learning terem as notas na disciplina um pouco mais altas e a tendência da média final na disciplina dos alunos que participaram da pesquisa serem mais altas que dos alunos de uma turma anterior (2001), principalmente se forem considerados os alunos da turma de 2002 com alta participação online;

- $\mathrm{O}$ aumento do interesse em Gestão de Pessoas por parte de alguns alunos decorrente das atividades de e-learning;

- A contribuição positiva das atividades de e-learning para o aprendizado do aluno, apesar da necessidade de melhoria (tendência de os alunos que perceberam maior contribuição, terem tido maior participação online e maior motivação).

Para completar esta breve síntese do capítulo, o Quadro 22 apresenta um resumo das principais sugestões de melhorias discutidas para cada atividade de $e$-learning. 
Quadro 22 - Resumo das Sugestões de Melhoria para cada Atividade de e-Learning

\begin{tabular}{|c|c|}
\hline Conteúdo & $\begin{array}{l}\text { Disponibilizar com maior rapidez as transparências apresentadas em classe. } \\
\text { Incluir maior número de textos extras para aprofundamento dos temas. } \\
\text { Manter o calendário atualizado com as atividades propostas. } \\
\text { Disponibilizar endereços de páginas na Internet e artigos sobre casos } \\
\text { práticos relacionados aos assuntos tratados na disciplina. } \\
\text { Disponibilizar conteúdos no início do semestre. }\end{array}$ \\
\hline $\begin{array}{l}\text { Testes } \\
\text { auto- } \\
\text { corrigidos }\end{array}$ & $\begin{array}{l}\text { Manter questões para estimular leitura, mas incluir questões para discutir } \\
\text { aspectos mais gerais de cada tema. } \\
\text { Comunicação clara dos objetivos da atividade. } \\
\text { Sensibilização sobre a contribuição da atividade para o aprendizado, com a } \\
\text { finalidade de minimizar a cópia dos resultados do colega. } \\
\text { Manter a correção instantânea das questões, divulgando o resultado para os } \\
\text { alunos. } \\
\text { Apresentar as respostas de forma mais clara. }\end{array}$ \\
\hline WebQuest & $\begin{array}{l}\text { Aumentar a duração da atividade (apenas iniciar durante a aula). } \\
\text { Melhorar a conclusão da atividade, mostrando aos alunos o que eles } \\
\text { aprenderam. }\end{array}$ \\
\hline Fórum & $\begin{array}{l}\text { Manter participação mínima obrigatória através do envio de mensagens e } \\
\text { estimular a inclusão de comentários com análise crítica. } \\
\text { Desenvolver critérios de avaliação da participação mais sofisticados, } \\
\text { objetivando estimular uma maior interação e troca entre os participantes. } \\
\text { Viabilizar uma maior participação dos professores e monitores, através da } \\
\text { criação antecipada das atividades do curso e gerenciamento da carga de } \\
\text { trabalho. }\end{array}$ \\
\hline Chat & $\begin{array}{l}\text { Discutir a questão da postura dos alunos antes do Chat e adotar práticas } \\
\text { como formação dos grupos com base em discussões anteriores e utilização } \\
\text { de critérios de avaliação da participação. } \\
\text { Propor novo formato que possibilite menos participantes e duração um } \\
\text { pouco maior. } \\
\text { Realizar o Chat após a aula presencial sobre o assunto da discussão. } \\
\text { Propor um WebQuest sobre o tema antes da discussão no Chat. }\end{array}$ \\
\hline
\end{tabular}




\subsection{A contribuição das atividades de e-learning no desenvolvimento de competências de aprendizagem e competências sociais}

Neste capítulo será analisada a opinião dos alunos em relação à contribuição das atividades de e-learning no desenvolvimento de competências de aprendizagem (autoaprendizagem e pesquisa na Internet) e de competências sociais (comunicação em ambientes virtuais, participação em discussões e formação de comunidades). Essas competências estão sendo analisadas separadamente da competência técnica, visto que não faziam parte do foco da disciplina estudada. Além disso, tendo em vista o caráter exploratório deste estudo e a escassez de pesquisas específicas sobre este assunto, esta parte da pesquisa foi realizada de forma mais geral, sem detalhar a contribuição de cada atividade.

Assim, com a finalidade de fornecer uma visão geral dos resultados obtidos em relação a este objetivo específico, a Tabela 8 apresenta a moda, média e desvio padrão das notas atribuídas pelos alunos para a contribuição do e-learning no desenvolvimento de competências de aprendizagem e sociais. Seguindo a mesma estrutura de análise dos tópicos anteriores, a seguir serão apresentados somente os resultados mais interessantes relacionados ao desenvolvimento das competências de aprendizagem e sociais.

Tabela 8 - Distribuição das Opiniões dos Alunos sobre o Grau de Contribuição do eLearning no Desenvolvimento de Competências de Aprendizagem e Sociais

\begin{tabular}{lccc}
\hline Questão & Moda* & Média* & DP \\
\hline $\begin{array}{l}\text { Contribuição das atividades de } \boldsymbol{e} \text {-learning para o } \\
\text { desenvolvimento de competências individuais }\end{array}$ & & & \\
$\begin{array}{l}\text { Auto-aprendizagem (responsabilidade pela condução da própria } \\
\text { aprendizagem) }\end{array}$ & 8 & 7,6 & 1,9 \\
Pesquisa na Internet & 7 & 6,9 & 2,3 \\
Comunicação em ambientes virtuais & 9 & 6,7 & 2,7 \\
Participação em discussões & 8 & 6,5 & 2,5 \\
Formação de comunidades virtuais para troca de conhecimentos & 5 & 6,2 & 2,8 \\
\hline
\end{tabular}

* Nota: $0=$ Péssimo e $10=$ Excelente 


\subsubsection{As Competências de Aprendizagem}

As notas atribuídas pelos alunos em relação à contribuição das atividades de $e$ learning para o desenvolvimento da auto-aprendizagem (responsabilidade pela condução da própria aprendizagem) estão apresentadas no Gráfico 27. De acordo com os dados obtidos, $59 \%$ dos alunos atribuíram uma boa nota (entre 8 e 10) para este item, indicando que, na percepção dos alunos, as atividades realizadas estimularam o desenvolvimento dessa competência; conforme mencionado por um aluno no questionário: “[o e-learning] é bom para aprender sozinho, e fica mais interessante quando usamos o Fórum e Chat". Além disso, a nota média desse item é a mais alta $(7,6)$ e a dispersão das respostas a menor $(1,9)$, se comparadas às notas atribuídas para o desenvolvimento das outras competências.

Gráfico 27 - Distribuição das Notas Atribuídas pelos Alunos para a Contribuição do eLearning no Desenvolvimento da Auto-aprendizagem

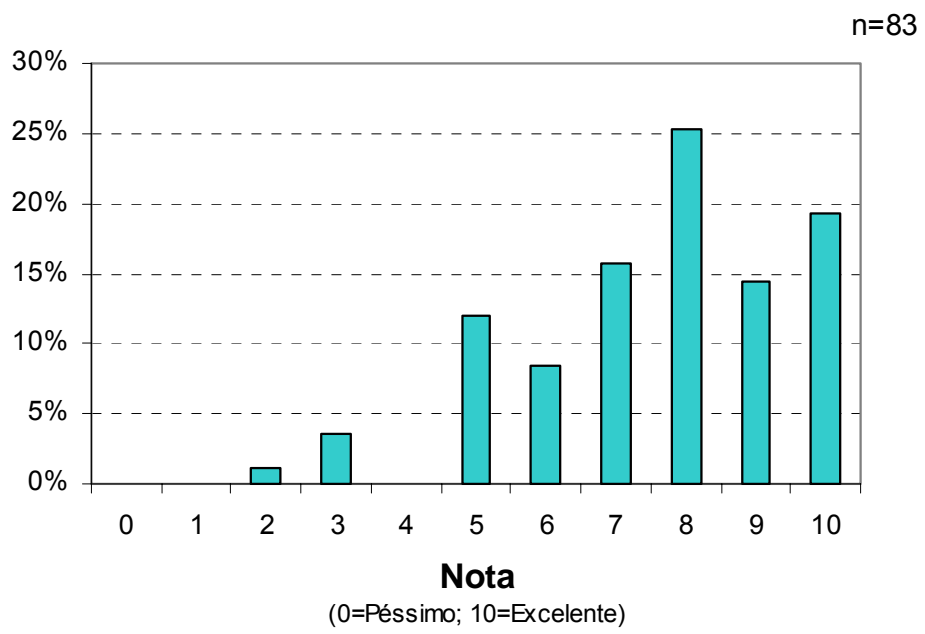

Este resultado é muito coerente com a literatura, que ressalta a posição ativa em que o aluno é colocado no caso do ensino utilizando e-learning (NUNES, 1993; GODOY, 1997b; LIMA, 2000; LANDIS, 2001) e a contribuição dessas atividades no desenvolvimento de condutas de aprendizado autônomo (RAMOS,1996). De acordo com MUELLER, “A Internet torna-se um ambiente propício para que o aluno tome para si a responsabilidade pelo seu aprendizado, pois facilita o acesso a uma série de informações e interações que em uma sala de aula jamais seria possível; tudo isto, reafirmando, com a devida orientação do professor" (2002). 
Uma análise mais detalhada das notas baixas $(<5)$ atribuídas para o desenvolvimento da auto-aprendizagem mostra que estes 4 alunos tiveram mais dificuldade na compreensão dos objetivos e instruções dos testes auto-corrigidos e da atividade WebQuest e, também, tiveram mais problemas para realizá-las (Tabela 9). Dessa forma, parece que os alunos que não perceberam desenvolvimento da auto-aprendizagem, também possuem maiores dificuldades para se adaptar em atividades mais autônomas, reforçando a importância de incentivar o desenvolvimento dessa competência.

Tabela 9 - Média e Desvio Padrão das Notas* Atribuídas pelos Alunos para as Atividades de e-Learning, por Faixa de Nota* Atribuída para a Contribuição do e-Learning no Desenvolvimento da Auto-aprendizagem

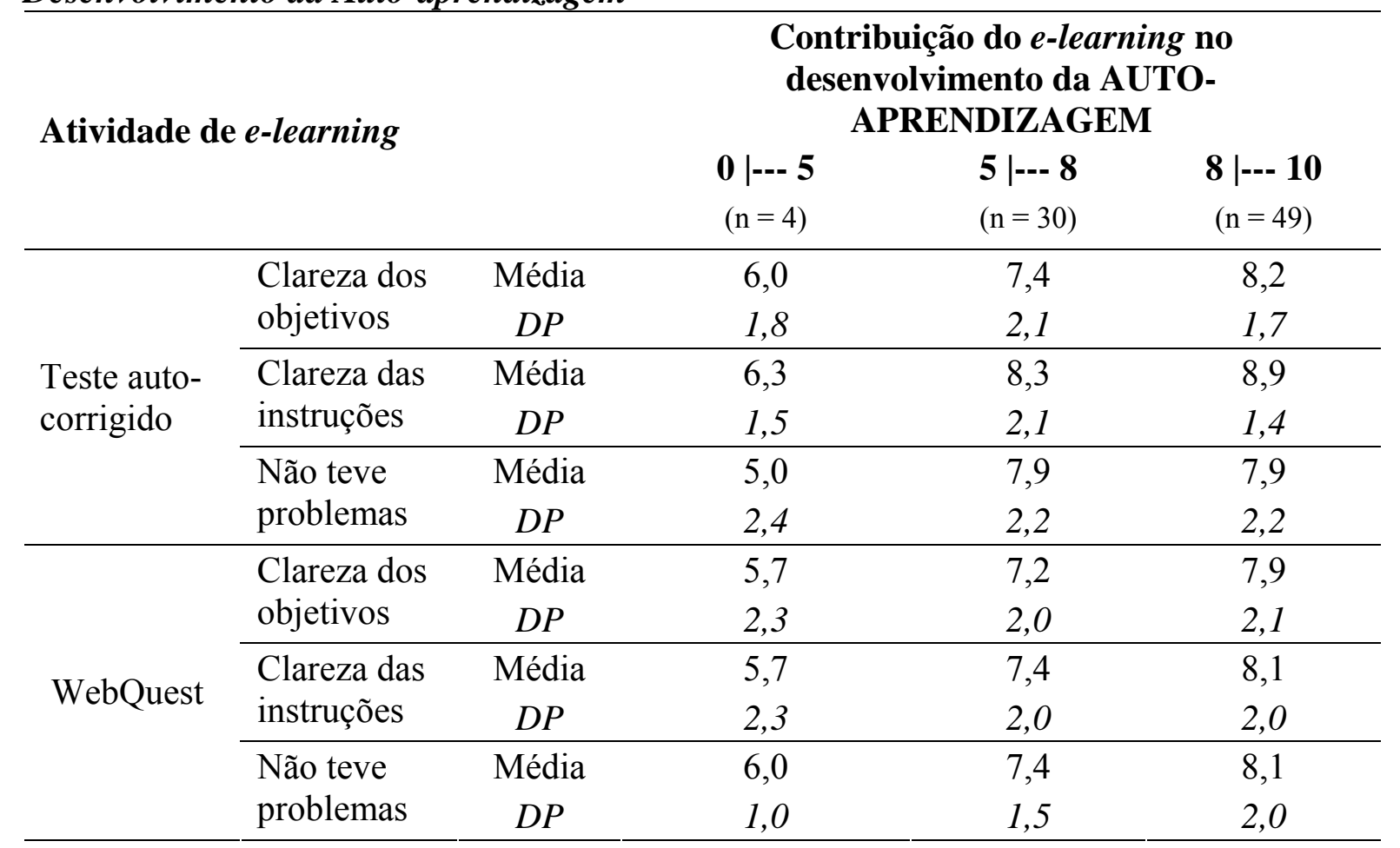

* Nota: $0=$ Péssimo e $10=$ Excelente

A partir da prova qui-quadrado ${ }^{31}$ foram identificadas as seguintes associações entre as notas atribuídas para o desenvolvimento da auto-aprendizagem e as notas atribuídas para o desenvolvimento de competências técnicas:

- $65 \%$ dos alunos que atribuíram nota entre 8 e 10 para auto-aprendizagem também atribuíram nota na mesma faixa para a contribuição dos testes auto-corrigidos para o aprendizado (nível de significância de 1\%);

31 Esta foi a única situação em que o teste qui-quadrado foi calculado considerando os 83 alunos que preencheram o Questionário de Avaliação ao invés do grupo de 61 alunos que preencheu todos os questionários. 
- $70 \%$ dos alunos que atribuíram nota entre 8 e 10 para auto-aprendizagem também atribuíram nota na mesma faixa para a contribuição do WebQuest para o aprendizado (nível de significância de 10\%);

- $38 \%$ dos alunos que atribuíram nota entre 8 e 10 para auto-aprendizagem também atribuíram nota na mesma faixa para a contribuição do Fórum para o aprendizado (nível de significância de 10\%);

- $52 \%$ dos alunos que atribuíram nota entre 8 e 10 para auto-aprendizagem também atribuíram nota na mesma faixa para a contribuição geral das atividades de $e$-learning para o aprendizado (nível de significância de 1\%), Gráfico 28.

\section{Gráfico 28 - Distribuição das Notas Atribuídas pelos Alunos em Relação ao Desenvolvimento da Auto-aprendizagem, por Nota Atribuída em Relação à Contribuição do e-Learning para o Aprendizado}

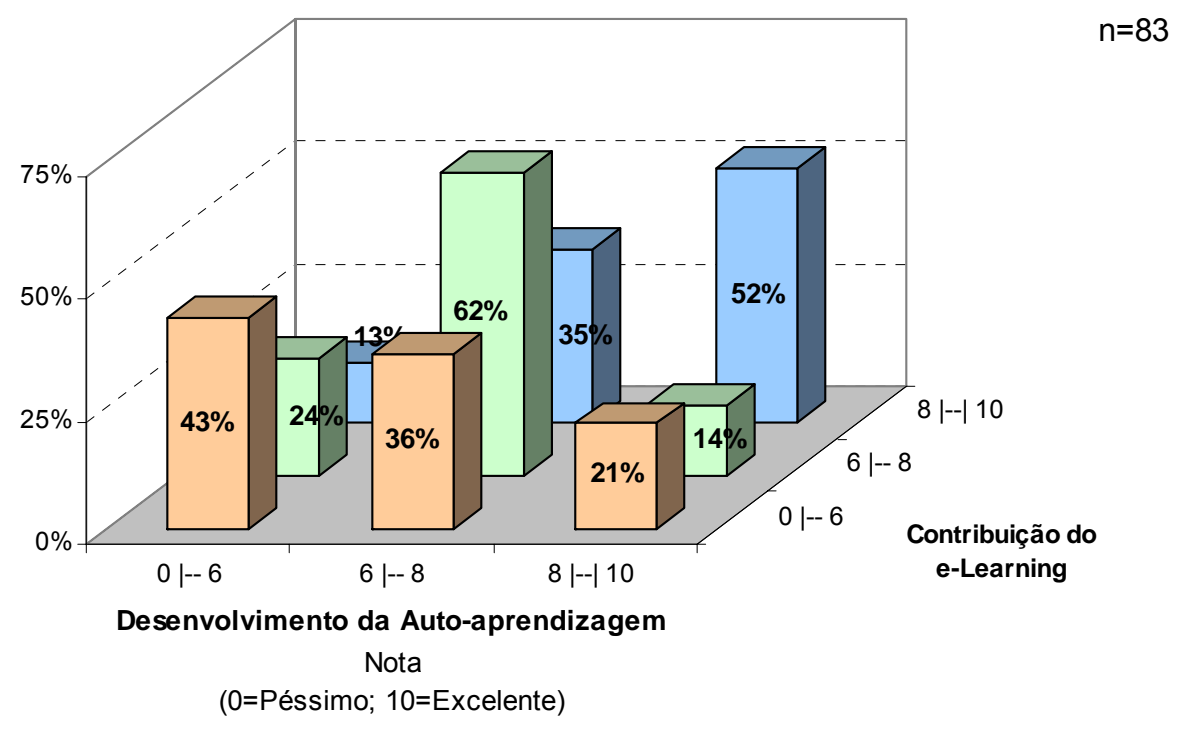

Compreendendo a auto-aprendizagem como uma competência importante para o aprendizado através do e-learning (LANDIS, 2001; PricewaterhouseCoopers, 2001), é possível supor que os alunos que perceberam um maior desenvolvimento da autoaprendizagem, também tenham aproveitado melhor as atividades online para $\mathrm{o}$ desenvolvimento de competências técnicas.

É interessante notar que a contribuição percebida do Fórum para o aprendizado também aparece entre as associações verificadas com o desenvolvimento percebido da autoaprendizagem. A contribuição do Chat também segue a mesma tendência, embora não a um 
nível significativo estatisticamente. Este resultado faz sentido, quando o aspecto social da auto-aprendizagem é analisado.

De acordo com NEVES ${ }^{32}$, "a autonomia não é um valor absoluto, fechado em si mesmo, mas um valor que se define numa relação de interação social” (1996 apud PRETI, 2000, p. 8); ou seja, a autonomia é uma conquista, "que se realiza à medida que o homem cresce e amadurece, no convívio com os outros" (PRETI, 2000, p. 7). Assim, "ser autônomo significa estar apto a cooperativamente construir o sistema de regras morais e operatórias necessárias à manutenção de relações permeadas pelo respeito mútuo" (RAMOS 1996, p. 7).

Dessa forma, é possível que os alunos com uma postura mais ativa no processo de ensino-aprendizagem, também tenham tido mais facilidade em aproveitar diferentes experiências e atividades para seu aprendizado, percebendo uma maior contribuição das discussões no Fórum e Chat, da atividade WebQuest e do e-learning como um todo.

Outra associação foi verificada entre as notas atribuídas para o desenvolvimento da auto-aprendizagem e as notas atribuídas em relação à motivação do aluno para realizar um bom trabalho, ao nível de significância de $10 \%$, ou seja, $68 \%$ dos alunos que afirmaram estarem motivados (nota $\geq 7$ ), atribuíram nota entre 8 e 10 para o desenvolvimento da autoaprendizagem. Considerando as dificuldades com insuficiência de recursos tecnológicos e com a falta de tempo, relacionadas à motivação e já discutidas anteriormente, é possível que estas também tenham impactado negativamente no desenvolvimento das competências de aprendizagem, além da técnica. No caso da pesquisa na Internet, apesar da associação não ser estatisticamente significativa, a mesma tendência é observada.

A percepção dos alunos em relação à contribuição do e-learning para o desenvolvimento da competência de pesquisa na Internet foi positiva, apesar de ser observado um número maior de notas baixas do que no caso da competência de auto-aprendizagem (Gráfico 29).

${ }^{32}$ NEVES, Carmem M. de Castro. Autonomia da escola pública: um enfoque operacional. In: VEIGA, Ilma Passos A. (Org.). Projeto Político-Pedagógico da escola: uma construção possível. 2. ed. Campinas: Papirus, 1996. 
Gráfico 29 - Distribuição das Notas Atribuídas pelos Alunos para a Contribuição do eLearning no Desenvolvimento da Pesquisa na Internet

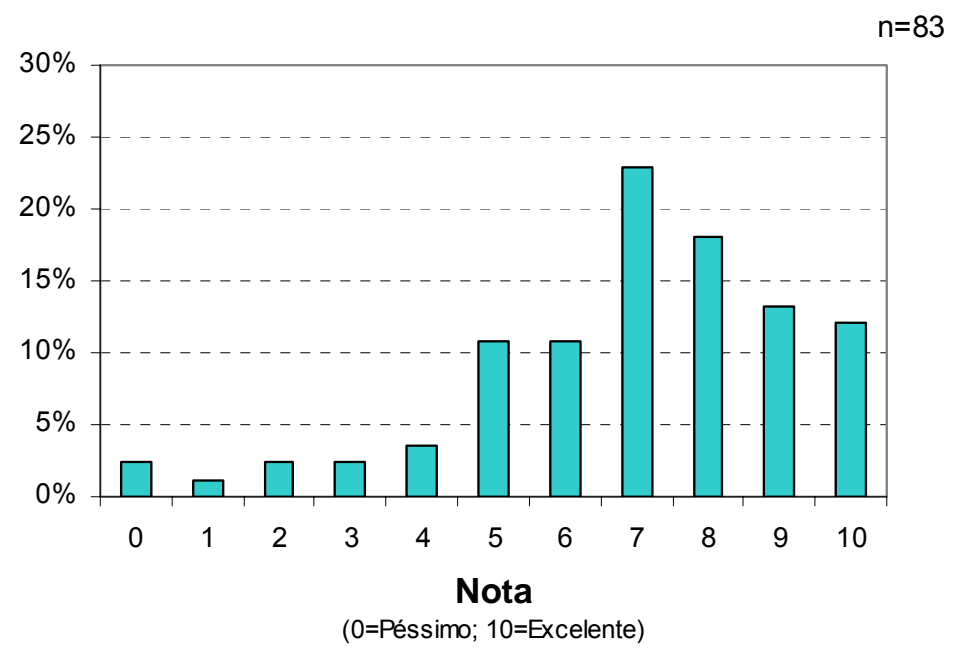

A explicação para algumas notas baixas pode ser obtida nos comentários de alguns alunos, que mencionaram já terem domínio da competência de pesquisa na Internet.

Verificou-se uma associação entre as notas atribuídas pelos alunos para a contribuição do e-learning no desenvolvimento da pesquisa na Internet e para a contribuição da atividade WebQuest, a um nível de significância de $10 \%$, se forem considerados somente os alunos com médio interesse por gestão de pessoas $(n=25)$, tornando o grupo mais homogêneo. Dessa forma, dos 16 alunos que atribuíram notas acima de 7 para o desenvolvimento da pesquisa na Internet, 11 atribuíram notas entre 8 e 10 em relação à contribuição do WebQuest para o aprendizado.

A associação entre o desenvolvimento da competência pesquisa na Internet com o nível de interesse do aluno por gestão de pessoas foi verificado (ao nível de significância de $5 \%$ ), resultado também verificado no tópico sobre o WebQuest, conforme já comentado. Os resultados mostram que $50 \%$ dos alunos com médio interesse atribuíram notas baixas (menor que 6) para o desenvolvimento da pesquisa na Internet, comparado a 5\% dos alunos de alto interesse que atribuíram notas na mesma faixa. É possível que os alunos mais interessados no tema tenham realizado mais pesquisas na Internet, o que contribuiu para o desenvolvimento dessa competência. 


\subsubsection{As Competências Sociais}

Os resultados do desenvolvimento das competências sociais (comunicação em ambientes virtuais, participação em discussões e formação de comunidades) estão diretamente vinculados às atividades de discussão online Fórum e Chat, já discutidas anteriormente. Assim, da mesma forma que foi verificado na análise do Fórum e do Chat, a contribuição do e-learning para o desenvolvimento de competências sociais também apresentou opiniões divergentes entre os alunos, tendo em vista os valores do desvio padrão acima de 2,5 (Tabela 8) e a distribuição das notas atribuídas pelos alunos para essas competências (Gráfico 30).

\section{Gráfico 30 - Distribuição das Notas Atribuídas pelos Alunos em Relação à Contribuição do e-Learning no Desenvolvimento de Competências Sociais}

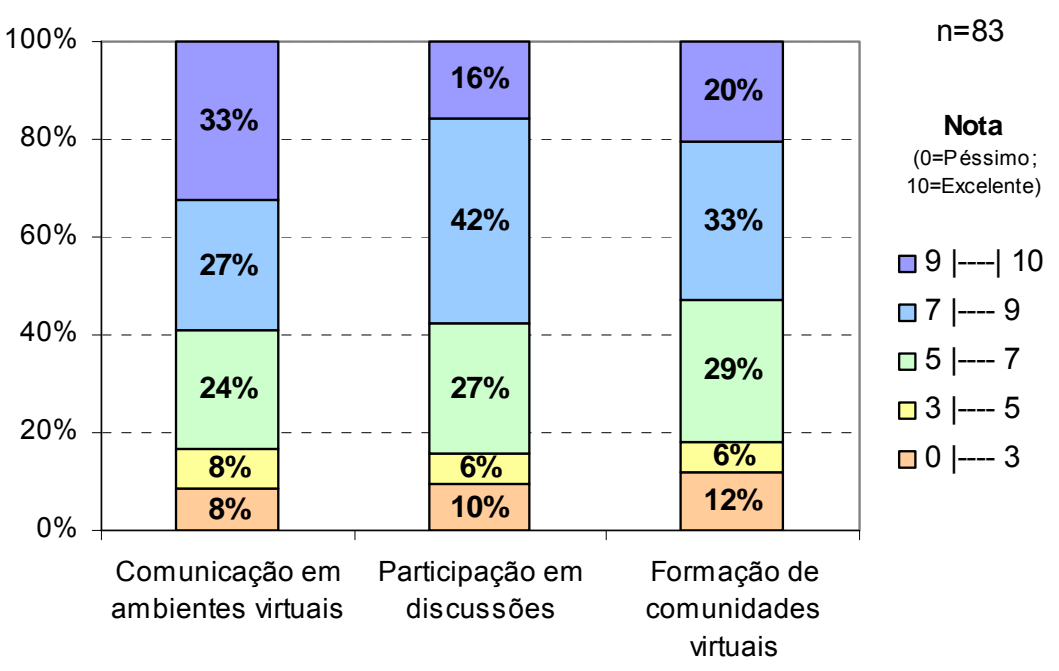

Apesar da variação das opiniões, é possível considerar que os alunos perceberam como mediana a contribuição do e-learning no desenvolvimento de competências sociais, visto que a média das notas de cada aspecto (comunicação em ambientes virtuais, participação em discussões e formação de comunidades virtuais) foi maior que 6 (Tabela 8). Além disso, uma parte das notas baixas pode ser explicada pelo fato de alguns alunos já possuírem grande habilidade para atuar em ambientes virtuais, resultando em uma limitada contribuição das atividades de e-learning realizadas, conforme indicado por alguns respondentes no campo das observações do questionário.

A verificação de um resultado mais positivo no caso do desenvolvimento da comunicação em ambientes virtuais e da participação em discussões (45\% das notas são de 8 a 10 em ambos os casos e moda igual a 9 e 8, respectivamente) está coerente com a literatura, que menciona que nas discussões online os alunos precisam pensar de forma mais crítica, 
provavelmente devido ao tipo reflexivo da comunicação, podendo resultar em aprimoramentos nas habilidades de comunicação dos alunos e no pensamento crítico (LANDIS, 2001; ROVAI, 2002; ONLINE..., 2003; MEYER, 2003; MURRAY e MASON, 2003).

Além disso, a percepção positiva em relação à contribuição do e-learning no desenvolvimento da comunicação e discussão é reforçada pelas melhorias observadas nas discussões online realizadas, resultantes da maior familiaridade de alunos e professores com a atividade, conforme sugerido na literatura (BROWN, 2001) e comentado pelos alunos (Quadro 21).

A partir da prova qui-quadrado foi identificada uma associação entre as notas atribuídas para a contribuição do e-learning no desenvolvimento da participação em discussões e as notas atribuídas para a oportunidade de expor opiniões no Fórum, a um nível de significância de 10\%; ou seja, dos alunos que perceberam como positiva a oportunidade de expor suas opiniões no Fórum (notas entre 9 e 10), 69\% também perceberam que o e-learning contribuiu no aprimoramento da capacidade de participar em discussões (notas entre 7 e 10). Esta tendência também pode ser observada em relação à oportunidade de expor opiniões no Chat, à profundidade da discussão e à contribuição para o aprendizado no Fórum e Chat (Tabela 10), embora não seja verificada uma associação estatística.

Dessa forma, parece que os alunos que perceberam o Fórum e o Chat como atividades que contribuíram para o aprendizado da matéria também perceberam a contribuição no desenvolvimento das competências de comunicação em ambientes virtuais e participação em discussões. Este resultado pode ser relacionado à possibilidade de alguns alunos se mostrarem mais preparados para aproveitar diferentes atividades de aprendizagem, enquanto outros parecem preferir manter o foco no conteúdo transmitido pelo professor. Além disso, outras questões, também já discutidas anteriormente, podem ter influenciado este resultado, como o interesse por Gestão de Pessoas, o nível de motivação para realizar um bom trabalho e o estilo de aprendizagem do aluno. 
Tabela 10 - Média e Desvio Padrão das Notas* Atribuídas pelos Alunos para as Atividades de e-Learning, por Faixa de Nota* Atribuída para a Contribuição do e-Learning no Desenvolvimento da Comunicação em Ambientes Virtuais e da Participação em Discussões

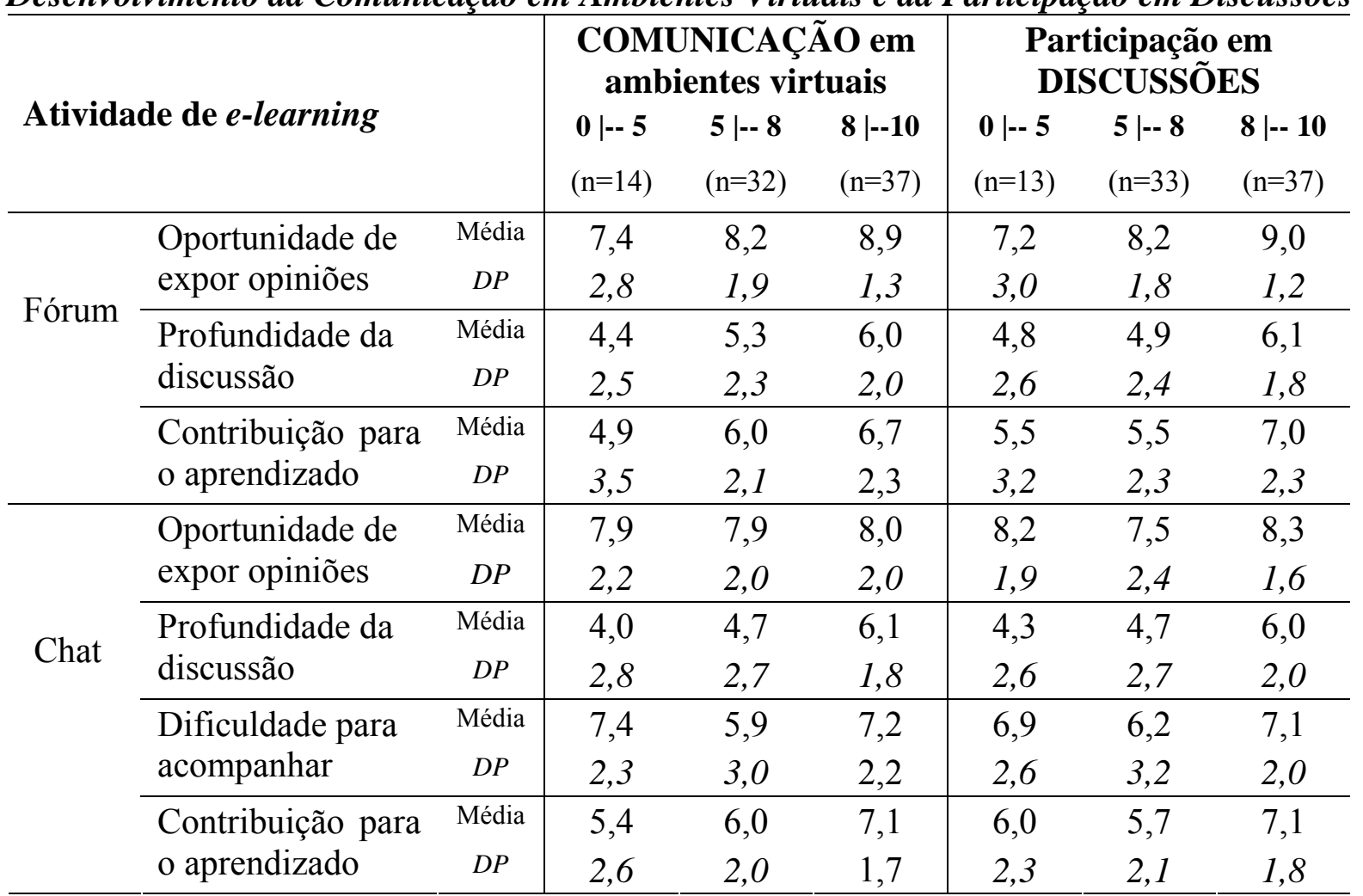

* Nota: $0=$ Péssimo e $10=$ Excelente

Especificamente, o nível de motivação do aluno para realizar um bom trabalho está associado às notas atribuídas para o desenvolvimento das competências comunicação em ambientes virtuais (nível de significância igual a 2,5\%), participação em discussões (nível de significância igual a 2,5\%) e formação de comunidades virtuais (nível de significância igual a $4 \%$ ); ou seja, os alunos que se consideraram mais motivados (nota igual ou maior que 7) atribuíram maiores notas para o desenvolvimento das competências sociais (notas de 8 a 10).

No caso específico da formação de comunidades virtuais para troca de conhecimentos, é observada a maior freqüência de notas abaixo de 5 (18\%), a menor moda (nota 5) e a menor freqüência de notas altas, entre 8 e 10,(37\%). Esta avaliação está coerente com as limitações observadas no Fórum e Chat, não viabilizando a formação de uma comunidade virtual, considerando a importância da interação e da experiência do instrutor na construção da comunidade (ROVAI, 2002). Por outro lado, as poucas notas altas reforçam a viabilidade da formação de comunidades em ambientes virtuais mencionada na literatura (ROVAI, 2002; CHAVES, 2001). Assim, é possível que o aprimoramento das atividades Fórum e Chat como um todo poderia impulsionar o desenvolvimento das competências sociais. 
Da mesma forma, à medida que os resultados indicam a contribuição moderada do $e$ learning no desenvolvimento de competências de aprendizagem e competências sociais, o aprimoramento desse método de ensino pode aumentar esta contribuição.

Com a finalidade de resumir os principais resultados relacionados ao desenvolvimento de competências de aprendizagem e competências sociais, tendo em vista o objetivo específico proposto, é possível destacar os seguintes aspectos:

- A contribuição positiva do e-learning no desenvolvimento da auto-aprendizagem, possivelmente relacionada à postura ativa necessária ao aluno neste método de ensino;

- Estímulo à cultura de auto-aprendizagem, permitindo ao aluno perceber outras atividades que podem contribuir para o aprendizado, além da transmissão de conteúdo pelo professor;

- Os alunos que não perceberam que a competência auto-aprendizagem foi desenvolvida tiveram mais dificuldade na compreensão dos objetivos e instruções e na realização das atividades;

- Os alunos que perceberam um maior desenvolvimento da auto-aprendizagem parecem ter aproveitado melhor as atividades online também para o desenvolvimento de competências técnicas;

- Algumas notas baixas em relação ao desenvolvimento de competências foram justificadas pelos alunos que já dominavam a competência em questão;

- Os alunos que perceberam uma contribuição maior da atividade WebQuest para o aprendizado também perceberam uma contribuição maior do e-learning para o desenvolvimento da pesquisa na Internet;

- Aprimoramento da pesquisa na Internet, principalmente por aqueles alunos com alto interesse no tema da disciplina;

- Os alunos com alto interesse em Gestão de Pessoas perceberam um maior desenvolvimento da pesquisa na Internet;

- Os alunos mais motivados para fazer um bom trabalho perceberam um maior desenvolvimento da auto-aprendizagem e das competências sociais;

- As opiniões quanto à contribuição do e-learning no desenvolvimento de competências sociais foram divergentes, sendo a contribuição positiva (embora limitada) percebida 
coerente com a necessidade de os alunos pensarem de forma mais crítica nas discussões online e com as melhorias verificadas nas discussões do Chat;

- Os alunos que perceberam o Fórum e o Chat como atividades que contribuíram para o aprendizado da matéria também perceberam a contribuição no desenvolvimento das competências de comunicação em ambientes virtuais e participação em discussões;

- A formação de comunidades virtuais foi impactada pelas limitações observadas no Fórum e Chat, resultando em desenvolvimento restrito dessa competência; apesar disso, os resultados indicam que existe potencial para desenvolvimento dessa competência.

\subsection{A influência do estilo de aprendizagem do aluno na utilização do e-learning para o desenvolvimento de competências do administrador}

Para atingir este objetivo, foram analisadas as relações entre a opinião dos alunos sobre a contribuição do e-learning no desenvolvimento de competências e seus tipos psicológicos, permitindo identificar possíveis preferências dos alunos em relação a estas atividades. Assim, serão discutidas as preferências dos alunos em relação ao $e$-learning e seus possíveis impactos no desenvolvimento de competências técnicas, de aprendizagem e sociais.

Os resultados serão apresentados em duas partes. Primeiramente, o perfil geral dos participantes da pesquisa será discutido. Em seguida, a disposição geral Introversão/Extroversão é analisada em relação às notas atribuídas pelos alunos sobre a contribuição do e-learning no desenvolvimento de competências técnicas (aprendizado da matéria), de aprendizagem e sociais. Com relação às outras funções psicológicas, são comentados apenas os resultados mais interessantes, considerando que estas parecem ter influenciado menos a opinião dos alunos sobre contribuição do e-learning no desenvolvimento de competências. Também foram incluídas na análise as variáveis intervenientes que auxiliaram no entendimento dos estilos de aprendizagem. 


\subsubsection{O Perfil Geral}

Para compreender melhor o perfil geral dos alunos que cursaram a disciplina pesquisada e responderam ao Inventário Brasileiro para Diagnóstico das Diferenças Individuais ( $\mathrm{n}=84)$ a freqüência de cada tipo psicológico no grupo foi calculada (Tabela 11).

Tabela 11 - Ocorrências Absolutas e Percentuais Totais de Tipo Psicológico, por Dimensão

\begin{tabular}{lll|cc|cc}
\hline \multirow{2}{*}{ Dimensão } & \multirow{2}{*}{ Tipo Psicológico } & & \multicolumn{2}{c|}{$\begin{array}{c}\text { Alunos que } \\
\text { responderam este } \\
\text { questionário (n=84) }\end{array}$} & \multicolumn{2}{c}{$\begin{array}{c}\text { Alunos que } \\
\text { responderam todos os } \\
\text { questionários (n=61) }\end{array}$} \\
& & & $\begin{array}{c}\text { Frequência } \\
\text { Absoluta }\end{array}$ & $\begin{array}{c}\text { Freqüência } \\
\text { Relativa }\end{array}$ & $\begin{array}{c}\text { Frequência } \\
\text { Absoluta }\end{array}$ & $\begin{array}{c}\text { Freqüência } \\
\text { Relativa }\end{array}$ \\
\hline $\begin{array}{l}\text { Tipos básicos } \\
\text { de disposição }\end{array}$ & Extroversão & $\mathrm{E}$ & 39 & $46,4 \%$ & 26 & $42,6 \%$ \\
\hline Funções & Introversão & $\mathrm{I}$ & 45 & $53,6 \%$ & 35 & $57,4 \%$ \\
perceptivas & Sensação & $\mathrm{S}$ & 48 & $\mathbf{5 7 , 1 \%}$ & 35 & $\mathbf{5 7 , 4 \%}$ \\
\hline Funções & Intuição & $\mathrm{N}$ & 36 & $42,9 \%$ & 26 & $42,6 \%$ \\
judicativas & Sensamento & $\mathrm{T}$ & 35 & $41,7 \%$ & 27 & $44,3 \%$ \\
\hline Postura frente & Julgamento & $\mathrm{J}$ & 33 & $\mathbf{5 8 , 3 \%}$ & 34 & $\mathbf{5 5 , 7 \%}$ \\
ao mundo & Percepção & $\mathrm{P}$ & 51 & $\mathbf{6 0 , 7 \%}$ & 38 & $\mathbf{6 2 , 3 \%}$ \\
\hline & & Total* & $\mathbf{8 4}$ & $\mathbf{1 0 0 \%}$ & $\mathbf{6 1}$ & $\mathbf{1 0 0 \%}$ \\
\hline
\end{tabular}

*O total refere-se à soma das freqüências de cada par de funções (primeira coluna).

Com base nos dados, uma freqüência mais alta dos tipos Sensação (S), Sentimento (F) e Percepção (P) é verificada. Para analisar este resultado, é preciso considerar que "as diferenças de preferências determinam escolhas profissionais que implicam em distribuições características nas diversas ocupações” (CASADO, 1998, p. 104).

Assim, a partir da pesquisa realizada por MYERS e McCAULLEY ${ }^{33}$ (1987 apud CASADO, 1998, p. 105), com 3678 pessoas de organizações diferentes (denominados genericamente "Gestores e Administradores"), verificou-se uma predominância de indivíduos com tipo Sensação (S), Pensamento (T) e Julgamento (J).

Uma análise comparativa dos resultados mencionados acima indica que os alunos participantes desta pesquisa formam um grupo atípico, com preferências um pouco diferentes do esperado na área de administração, no que se refere à função perceptiva e à "postura frente

\footnotetext{
${ }^{33}$ MYERS, Isabel B.; McCAULLEY, M. H. Manual: a Guide to the Development and Use of the Myers-Briggs Type Indicator. California: Consulting Psychologists Press, 1987.
} 
ao mundo". Dessa forma, considerando a predominância da função perceptiva "Sentimento", é possível que o grupo tenha sentido mais falta do aspecto social, menos presente no $e$ learning. Além disso, esta questão também pode ajudar a explicar a melhor aceitação do Chat, visto que essa atividade possui um potencial maior para interações sociais e emocionais (CHOU, 2001), se comparada ao Fórum.

No caso da "postura frente ao mundo", é possível que uma turma com predominância do tipo Julgamento $(\mathrm{J})$, tivesse participado mais do que foi verificado nesta pesquisa (grupo com predominância Percepção), tendo em vista o forte direcionamento do tipo Julgamento para a conclusão de tarefas (CASADO, 1998; BOOTH e WINZAR, 1993).

Também foi incluída na Tabela 11 a freqüência dos tipos psicológicos do grupo de alunos que responderam todos os questionários desta pesquisa $(n=61)$, com o objetivo de mostrar que os dados são próximos ao grupo de 84 alunos. Sendo assim, as próximas análises serão realizadas com base no grupo de 61 alunos.

Ainda com relação a aspectos gerais do grupo de respondentes, ao analisar as possíveis combinações dos tipos foi observada uma alta freqüência de alunos com o tipo Intuição/Sentimento/Percepção (sigla NFP, se considerada a nomenclatura apresentada no Quadro 5), representando 30\% do total de respondentes (tanto na amostra de 61, quanto na amostra de 84 alunos). Na seqüência, o segundo tipo mais freqüente ( $18 \%$ na amostra de $n=84$ e $20 \%$ na amostra de $n=61$ ) foi o Sensação/Pensamento/Julgamento (STJ), considerado mais característico do administrador (CASADO, 1998; MYERS e McCAULLY, 1987).

A seguir, os principais resultados da pesquisa serão analisados com maior detalhe. Com o objetivo de facilitar a leitura, as preferências de cada tipo psicológico em relação ao aprendizado é retomada, a partir do Quadro 5, apresentado no capítulo de revisão bibliográfica. 


\subsubsection{A relação com o objeto: Introversão / Extroversão}

Com base nas preferências apresentadas no Quadro 23, a seguir, é possível verificar uma maior aproximação do tipo introvertido com o e-learning, tendo em vista sua preferência pela leitura e adaptação ao trabalho solitário.

Quadro 23 - Preferências de Aprendizado dos Tipos Introversão / Extroversão

\begin{tabular}{l|l}
\hline \multicolumn{1}{c|}{ Introversão (I) } & \multicolumn{1}{c}{ Extroversão (E) } \\
Idéias, relacionamentos & Fatos específicos \\
Pensamento, profunda concentração & Ação espontânea \\
Regras em primeiro lugar & Exemplos em primeiro lugar \\
Leitura, raciocínio verbal & Conversa, discussão, com um grupo \\
Satisfação com trabalho solitário & Gosta de ter pessoas ao redor \\
Conceitos & Aplicação prática \\
Testes escritos & Testes orais \\
& Atividade psicomotora \\
\hline
\end{tabular}

Dessa forma, o fato de os alunos introvertidos terem tido uma maior participação online está coerente com as características desse tipo psicológico. A Tabela 12, apresentada, a seguir, mostra que $63 \%$ dos alunos introvertidos tiveram alta participação online, comparado a apenas $42 \%$ dos extrovertidos com o mesmo nível de participação. Resultado reforçado pelo teste qui-quadrado, indicando que os alunos Introvertidos leram mais mensagens no Fórum e também navegaram mais pelas páginas de conteúdo (maior número de Hits), associação verificada a um nível de significância igual a 10\% em ambos os casos.

Tabela 12 - Freqüência dos Tipos Introversão e Extroversão em Relação ao Nível de Participação Online

\begin{tabular}{lcc}
\hline Participação online* & Introversão (n=35) & Extroversão (n=26) \\
\hline Alta & $63 \%$ & $42 \%$ \\
Baixa & $37 \%$ & $58 \%$ \\
\hline Total & $100 \%$ & $100 \%$ \\
\hline
\end{tabular}

*Critérios p/ cálculo da participação online: $\mathrm{n}^{\circ}$ de Hits $\geq 100$; mensagens enviadas $\geq 4$; mensagens lidas $\geq 20$ Baixa participação online: nenhum ou somente um dos critérios é atendido Alta participação online: pelo menos dois dos critérios são atendidos

Dessa forma, parece fazer sentido que o nível de participação online do aluno esteja associado com a disposição geral da teoria de tipos psicológicos (relação do indivíduo com o objeto), ou seja, o aluno do tipo Introversão, que busca energia em seus processos internos, provavelmente sentiu mais interesse em realizar as atividades de e-learning, tendo em vista que se satisfaz com atividades solitárias, resultando em um nível de participação online mais alto. Por outro lado, o aluno do tipo Extroversão, aquele que busca no ambiente a energia, 
através da interação social, possivelmente não achou as atividades de e-learning tão interessantes, principalmente, se forem consideradas as limitações em relação às discussões online, já discutidas anteriormente.

Além disso, de forma geral, os alunos do tipo introversão também atribuíram maiores notas para a contribuição das atividades de e-learning no aprendizado do conteúdo, foco da disciplina pesquisada, ou seja, no desenvolvimento de competências técnicas, tendo em vista as maiores notas médias (Tabela 13). Reforçando esta tendência, no caso da contribuição do Chat, foi verificada uma associação significativa através do teste qui-quadrado (nível de significância igual a 10\%), considerando que 34\% dos alunos do tipo introversão atribuíram notas altas (entre 8 e 10) para este aspecto, comparado com 12\% dos alunos do tipo Extroversão que, também, atribuíram notas altas. Uma explicação plausível para este resultado seria os alunos Introversão terem sentido mais liberdade para participar da discussão no Chat, considerando suas preferências pela linguagem escrita; aspecto que está coerente com os comentários de alunos e professores sobre a maior participação na discussão do Chat de alunos que não costumam participar em sala de aula.

Por outro lado, a Tabela 13 mostra que os alunos do tipo Extroversão atribuíram notas mais altas em relação à contribuição do e-learning no desenvolvimento das competências de aprendizagem e competências sociais, ou seja, esses alunos perceberam que as atividades de e-learning os ajudaram mais na melhoria dessas competências, se comparado aos alunos do tipo Introversão. No caso da auto-aprendizagem, a comparação do valor da moda calculada nestes dois grupos reforça essa tendência: moda das notas do tipo Extroversão é igual a 10; moda das notas do tipo Introversão é igual a 8. 
Tabela 13 - Média e Desvio Padrão das Notas* Atribuídas pelos Alunos para o Desenvolvimento de Competências, por Tipo Introversão/Extroversão

\begin{tabular}{|c|c|c|c|}
\hline \multirow{2}{*}{\multicolumn{2}{|c|}{$\begin{array}{l}\text { Contribuição das atividades de } e \text {-learning para o } \\
\text { desenvolvimento de competências técnicas }\end{array}$}} & Introversão $(n=35)$ & \multirow[t]{2}{*}{ Extroversão (n=26) } \\
\hline & & & \\
\hline \multirow{2}{*}{ Contribuição dos testes auto-corrigidos } & Média & 7,48 & 7,12 \\
\hline & $D P$ & 2,20 & 2,64 \\
\hline \multirow{2}{*}{ Contribuição do WebQuest } & Média & 7,48 & 7,45 \\
\hline & $D P$ & 2,41 & 1,65 \\
\hline \multirow{2}{*}{ Contribuição do Fórum } & Média & 6,68 & 5,08 \\
\hline & $D P$ & 2,06 & 3,05 \\
\hline \multirow{2}{*}{ Contribuição do Chat } & Média & 6,41 & 6,04 \\
\hline & $D P$ & 1,97 & 1,81 \\
\hline \multirow{2}{*}{ Contribuição geral do e-learning } & Média & 7,14 & 6,65 \\
\hline & $D P$ & 1,65 & 2,02 \\
\hline \multicolumn{4}{|c|}{$\begin{array}{l}\text { Contribuição das atividades de e-learning para o desenvolvimento } \\
\text { de competências de aprendizagem e competências sociais }\end{array}$} \\
\hline \multirow{2}{*}{ Auto-aprendizagem } & Média & 7,71 & 7,92 \\
\hline & $D P$ & 1,53 & 1,83 \\
\hline \multirow{2}{*}{ Pesquisa na Internet } & Média & 6,71 & 7,65 \\
\hline & $D P$ & 2,28 & 1,74 \\
\hline \multirow{2}{*}{ Comunicação em ambientes virtuais } & Média & 6,31 & 7,31 \\
\hline & $D P$ & 2,27 & 2,87 \\
\hline \multirow{2}{*}{ Participação em discussões } & Média & 6,43 & 6,88 \\
\hline & $D P$ & 2,54 & 2,30 \\
\hline \multirow{2}{*}{ Formação de comunidades virtuais } & Média & 5,66 & 7,08 \\
\hline & $D P$ & 2,92 & 2,06 \\
\hline
\end{tabular}

* Nota: $0=$ Péssimo e $10=$ Excelente

Além disso, em relação ao desenvolvimento da comunicação em ambientes virtuais, $31 \%$ dos alunos do tipo Extroversão atribuíram nota 10 para este aspecto, comparado a apenas 3\% dos alunos do tipo Introversão que atribuíram a mesma nota. Esta mesma tendência é verificada no caso da formação de comunidades vituais, tendo em vista a associação identificada através da prova qui-quadrado (nível de significância igual a 0,2\%). Assim, dos 10 alunos que atribuíram notas menores que 5 para o desenvolvimento da formação de comunidades, apenas 1 era extrovertido, sendo os outros 9 introvertidos $^{34}$. Este resultado possibilita duas análises distintas: (1) é possível que os alunos do tipo Extroversão, por

\footnotetext{
${ }^{34}$ É importante comentar que este resultado não contradiz a análise realizada no tópico anterior sobre os alunos que atribuíram maiores notas para o desenvolvimento da auto-aprendizagem, também terem atribuído maiores notas para o desenvolvimento de competências técnicas (Gráfico 28), visto que se for analisada no detalhe a
} 
preferirem aprender através da interação com o outro, valorizaram mais a formação de comunidades, atribuindo notas mais altas; (2) por outro lado, é possível que os alunos do tipo Extroversão, por preferirem se comunicar oralmente, tiveram uma oportunidade de aprimorar sua competência de comunicação escrita (ambiente virtual), resultando em uma nota mais alta em relação ao auxílio do e-learning nesta tarefa.

Assim, as diferenças nas médias das notas dos alunos introvertidos e extrovertidos indicam os dois sentidos em que o e-learning pode contribuir na formação do administrador: (1) auxiliar no aprendizado da matéria do curso no caso dos alunos com estilo de aprendizagem mais compatível com as atividades de e-learning (introvertidos); (2) ajudar no desenvolvimento de competências (como auto-aprendizagem, pesquisa e atuação em ambientes virtuais) que acabam ficando de lado por não estarem alinhadas com as preferências destes alunos (extrovertidos).

Sobre este segundo aspecto é possível que as atividades de e-learning possam colocar o aluno do tipo extroversão em contato com aspectos opostos à sua preferência (no caso a introversão), resultando em uma oportunidade de aprimoramento. Considerando que as disposições e funções psicológicas opostas são representadas pela Função Sombra, o uso destas funções permite a ampliação da personalidade e o desenvolvimento do indivíduo. Assim o contato com a sombra é o primeiro passo para possibilitar a integração dos opostos, cuja importância é mencionada por CASADO: “[...] se os aspectos sombrios não são reconhecidos e integrados pelo sujeito, surgem inadaptações de toda sorte, que podem se manifestar desde a ineficiência profissional até implicações mais graves para a saúde do homem e da organização" (1993, p.103). Dessa forma,

O homem que faz uso das suas habilidades e características ditadas pelas funções psicológicas superiores e lida com seus opostos, tem maiores chances de aprimoramento e de evolução pessoal. Pensando do ponto de vista da empresa, [...] tal homem terá mais possibilidades de atuar eficientemente na sua vida profissional (CASADO, 1993, p.103). 


\subsubsection{As Outras Funções Psicológicas}

$\mathrm{Na}$ análise dos tipos extrovertido e introvertido, foi possível identificar aquele que, de forma geral, tinha um maior potencial para se adaptar ao e-learning; já no caso das outras funções as preferências não são tão claras. O Quadro 24, a seguir, retoma as principais preferências de cada um dos tipos das funções perceptivas, judicativas e postura frente ao mundo, já comentadas no capítulo dois (revisão bibliográfica).

\section{Quadro 24 - Preferências de Aprendizado dos Tipos Psicológicos (complemento do Quadro} 23)

Sensação (S)

Real, concreto, tangível

Sem complicação

Tarefas que envolvem cuidado, perfeição

Progresso passo a passo

Observação de detalhes

Regras-exemplo com muitas variações

Memória de fatos, detalhes

Interesses práticos

Desempenho, inteligência motor espacial

Testes de escolhas objetivas

Aplicação do que aprendeu

Objetivo

Pensamento (T)

Lógico, organização sistemática

Justiça

Cético, crítico

Matemática, ciência, habilidade técnica

\section{Julgamento (J)}

Decisivo

Trabalha de forma estável e ordenada

Instrução formalizada, estrutura

Decisões muito rápidas

Tarefas pré-determinadas

Direcionado para a conclusão

Dever, aplicação

No prazo

\section{Intuição (N)}

Significados, palavras, símbolos, abstrações Complexo

Tarefas que envolvem rápidos insights e percepção de relacionamentos

Encontrando o próprio caminho no novo material, descoberta

Lampejos de insights

Exemplos suficientes para ter um princípio

Compreensão de conceitos gerais

Imaginação, possibilidades

Interesses intelectuais (independente da

capacidade e inteligência)

Leitura

Testes com tempo determinado, analítico, teórico

Aprendizado de novos modelos

Subjetivo

Valor, mérito

Aprendizado através de relações interpessoais

Elogios

Harmonia, amizade

Consciência social

\section{Curioso}

\section{Percepção (P)}

Trabalha de forma flexível, segue impulsos

Resolução informal de problemas

Decisões só com muita informação

Tarefas descobertas

Gerenciamento de problemas emergentes

Ações improvisadas, adaptação à mudança

Segue o fluxo

Ainda aberto para mais informações

Conforme já mencionado anteriormente, apenas alguns aspectos sobre os outros tipos psicológicos, além da Introversão/Extroversão, serão comentados. Também, em algumas 
análises, os tipos psicológicos foram combinados com os tipos Introversão/Extroversão, de forma a evitar que o resultado fosse apenas reflexo deste último. A Tabela 14, apresenta a média e desvio padrão das notas atribuídas pelos alunos agrupados pelos tipos psicológicos, complementando a Tabela 13 apresentada no tópico anterior.

Tabela 14 - Média e Desvio Padrão das Notas* Atribuídas pelos Alunos para o Desenvolvimento de Competências, por Tipo Psicológico (complemento da Tabela 13)

\begin{tabular}{|c|c|c|c|c|c|c|c|}
\hline & & $\begin{array}{c}\text { Sensação } \\
(n=35)\end{array}$ & $\begin{array}{c}\text { Intuição } \\
(n=26)\end{array}$ & $\begin{array}{l}\text { Pensa- } \\
\text { mento } \\
(n=27)\end{array}$ & $\begin{array}{l}\text { Senti- } \\
\text { mento } \\
(n=34)\end{array}$ & $\begin{array}{l}\text { Julga- } \\
\text { mento } \\
(n=23)\end{array}$ & $\begin{array}{c}\text { Percepção } \\
(\mathbf{n}=38)\end{array}$ \\
\hline $\begin{array}{l}\text { Contribuição das ativid } \\
\text { técnicas }\end{array}$ & des de & -learnin & garand & envolvi & ento de & mpetê & \\
\hline Contribuição dos testes & Média & 6,97 & 7,83 & 6,92 & 7,64 & 7,13 & 7,44 \\
\hline auto-corrigidos & & 2,54 & 2,10 & 2,81 & 1,98 & 1,87 & 2,69 \\
\hline Contribuição do & Média & 7,66 & 7,19 & 6,96 & 7,87 & 7,47 & 7,47 \\
\hline WebQuest & $D P$ & 1,89 & 2,42 & 2,69 & 1,46 & 2,27 & 2,05 \\
\hline Contribuicãodo Fórum & Média & 6,03 & 5,96 & 6,00 & 6,00 & 6,09 & 5,94 \\
\hline 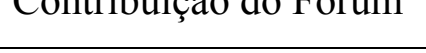 & $D P$ & 2,63 & 2,68 & 2,75 & 2,57 & 2,47 & 2,76 \\
\hline Contrihuicãodo Chat & Média & 6,40 & 6,04 & 6,07 & 6,41 & 6,04 & 6,39 \\
\hline Contribuiçao do Cnat & $D P$ & 1,96 & 1,83 & 2,15 & 1,68 & 1,89 & 1,92 \\
\hline Contribuição geral do $e$ - & Média & 7,06 & 6,77 & 6,85 & 7,00 & 6,91 & 6,95 \\
\hline learning & $D P$ & 1,76 & 1,90 & 2,20 & 1,48 & 1,95 & 1,75 \\
\hline $\begin{array}{l}\text { Contribuição das ativid } \\
\text { aprendizagem e compe }\end{array}$ & $\begin{array}{l}\text { des de } \\
\text { ncias } \mathrm{S}\end{array}$ & $\begin{array}{l}\text {-learnir } \\
\text { ciais }\end{array}$ & ra od & nvolv & nto de & mpetê & de \\
\hline & Média & 7,74 & 7,88 & 7,63 & 7,94 & 8,13 & 7,61 \\
\hline Auto-aprendızagem & $D P$ & 1,65 & 1,68 & 1,64 & 1,67 & 1,46 & 1,75 \\
\hline & Média & 6,80 & 7,54 & 7,15 & 7,09 & 7,22 & 7,05 \\
\hline Pesquisa na Internet & $D P$ & 2,18 & 1,96 & 1,88 & 2,30 & 1,68 & 2,35 \\
\hline Comunicação em & Média & 6,43 & 7,15 & 6,59 & 6,85 & 6,74 & 6,74 \\
\hline ambientes virtuais & $D P$ & 2,78 & 2,24 & 2,62 & 2,56 & 2,36 & 2,72 \\
\hline Participação em & Média & 6,23 & 7,15 & 6,44 & 6,76 & 7,04 & 6,37 \\
\hline discussões & $D P$ & 2,67 & 1,99 & 2,39 & 2,49 & 2,27 & 2,52 \\
\hline Formação de & Média & 5,69 & 7,04 & 6,33 & 6,21 & 5,78 & 6,55 \\
\hline comunidades virtuais & $D P$ & 2,93 & 2,07 & 2,60 & 2,75 & 2,84 & 2,54 \\
\hline
\end{tabular}

* Nota: $0=$ Péssimo e $10=$ Excelente

Iniciando a análise com os tipos Sensação/Intuição, os resultados mostraram que, diferentemente do que era esperado, os alunos do tipo Sensação atribuíram notas mais baixas para a contribuição dos testes auto-corrigidos para o aprendizado, resultando em uma menor nota média (Tabela 14) e menor moda (igual a 7, sendo a moda do tipo Intuição igual a 10), apesar da objetividade envolvida neste tipo de atividade que tenderia a agradar mais o tipo Sensação. Uma possível explicação para esta avaliação se refere ao conteúdo das questões, na maioria relacionadas aos conceitos e teorias apresentados nos textos para leitura, aspectos 
mais próximos do tipo Intuição. Assim, como recomendação para o planejamento deste tipo de atividade, seria interessante manter um equilíbrio entre questões puramente teóricas e questões que relacionem a teoria com a prática de forma a criar interesse nos alunos dos dois tipos psicológicos (Intuição e Sensação).

Analisando outro aspecto do desenvolvimento de competências técnicas, os alunos do tipo Introversão/Sensação (IS) atribuíram notas mais altas em relação à contribuição do Chat para o aprendizado (Gráfico 31), se comparado ao tipo Introversão/Intuição (IN), resultando em uma associação a um nível de significância de 10\% (prova qui-quadrado). Além disso, este grupo de alunos (IS) teve maior facilidade para acompanhar a discussão síncrona, associação verificada ao nível de significância de 4\% (teste qui-quadrado), visto que dos 20 alunos Introversão/Sensação 10 atribuíram notas entre 8 e 10 para este aspecto, comparado com 3 alunos Introversão/Intuição que atribuíram notas na mesma faixa, de um total de 14 alunos. Uma alternativa que pode explicar este resultado se refere à falta de embasamento teórico e superficialidade verificada na discussão do Chat, conforme comentado por alguns alunos e já discutido anteriormente, contrapondo a preferência do tipo Intuição por conteúdos teóricos e complexos.

\section{Gráfico 31 - Distribuição das Notas Atribuídas pelos Alunos em Relação à Contribuição do Chat para o Aprendizado, por Tipo Sensação/Intuição, Considerando apenas os Alunos do Tipo Introversão}

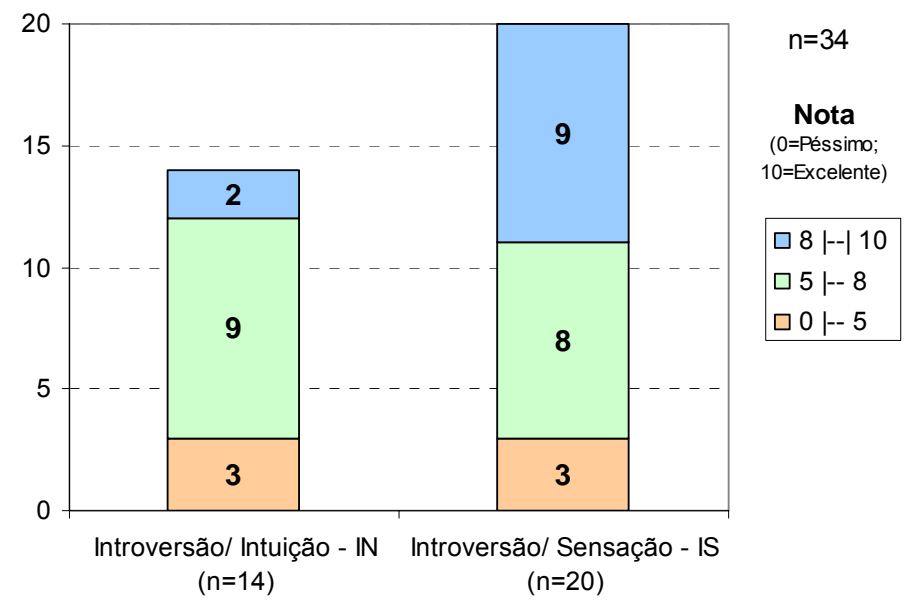

Conforme já discutido na apresentação dos resultados sobre as atividades de $e$ learning, os alunos que atribuíram notas mais altas para a adequada substituição da aula presencial pela virtual, também atribuíram notas mais altas para a contribuição do Chat e do e-learning para o aprendizado. Complementando esta análise, foi identificada uma associação, ao nível de significância de 4\%, entre as notas atribuídas para a adequada substituição da aula 
presencial pela virtual e os tipos Extroversão/Sensação e Extroversão/Intuição; 9 alunos do tipo Extroversão/Sensação $(n=15)$ atribuíram notas maior ou igual a 6 para este aspecto, enquanto apenas 2 alunos Extroversão/Intuição $(n=11)$ atribuíram notas na mesma faixa (Gráfico 32).

Gráfico 32 - Distribuição das Notas Atribuídas pelos Alunos em Relação à Adequada Substituição da Aula Presencial pela Virtual, por Tipo Sensação/Intuição, Considerando apenas os Alunos do Tipo Extroversão

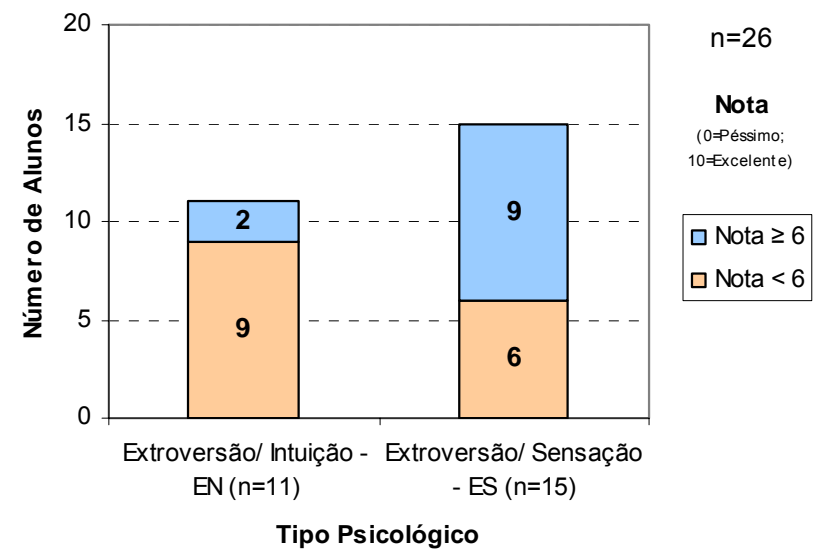

Assim, a percepção dos alunos que acharam inadequada a substituição do presencial pelo virtual parece estar relacionada, em parte, pela manutenção da postura passiva de alguns alunos no processo de aprendizagem e, em parte, pelas preferências associadas ao estilo de aprendizagem dos alunos (além de outras possibilidades já discutidas). Assim, considerando que o tipo Intuição possui preferências relacionadas à complexidade e aos significados, símbolos e abstrações parece coerente que os alunos deste tipo tenham preferência pela dinâmica da sala de aula, onde estes aspectos estão mais presentes. Assim, este resultado indica que, além de ser importante desenvolver uma cultura de auto-aprendizagem, também é necessário ter em mente as diferentes necessidades relacionadas aos diferentes estilos de aprendizagem dos alunos. Dessa forma, através da utilização de diferentes estratégias de ensino é possível aumentar a atenção e motivação dos alunos de todos os estilos de aprendizagem (BOOTH e WINZAR, 1993).

Mudando o foco da análise para os tipos Sentimento/Pensamento, nota-se que os alunos do tipo Sentimento atribuíram notas mais altas em relação à contribuição dos testes auto-corrigidos, do WebQuest e do Chat para o aprendizado e da contribuição do e-learning no desenvolvimento da auto-aprendizagem (notas verificadas na Tabela 14, sendo a diferença acentuada quando se considera também o tipo Introversão/Extroversão). 
No caso da opinião dos alunos Sentimento em relação ao quanto que o e-learning auxiliou no desenvolvimento da auto-aprendizagem, além da nota média maior (Tabela 14) a moda também é maior (igual a 10), se comparado com a moda igual a 8 das notas do tipo Pensamento. Uma possível explicação pode estar relacionada à preferência do tipo Sentimento por aprender através das relações interpessoais; sendo assim, os alunos deste tipo podem ter aproveitado as atividades de e-learning para estudar mais individualmente, o que pode explicar a percepção deles de que o e-learning contribuiu mais para o desenvolvimento da auto-aprendizagem.

Com base nestes resultados, surge uma questão interessante a ser discutida, relacionada ao instrumento de avaliação do curso: será que os alunos do tipo Sentimento apresentam uma tendência para atribuir notas mais altas que os demais tipos ao preencher uma avaliação? Este é um aspecto importante a ser pesquisado, tendo em vista a utilização de questionários de avaliação do ensino como instrumento de aprimoramento.

Um resultado curioso relacionado à função Julgamento/Percepção se refere ao aumento do interesse do aluno em Gestão de Pessoas decorrente das atividades de e-learning. Dos alunos com baixo ou médio interesse no tema que consideraram que este aumentou (7 alunos), a maioria deles são do tipo Percepção (6 alunos). É provável que o aluno do tipo Percepção tenha se interessado pelo e-learning, tendo em vista sua preferência por atividades flexíveis e por tarefas a serem descobertas.

No caso da opinião em relação ao quanto o e-learning ajudou no desenvolvimento da auto-aprendizagem, os alunos do tipo Julgamento atribuíram maiores notas se comparados ao tipo Percepção, tendo em vista a média maior e desvio padrão menor; nota média que também se destaca como a mais alta dentre todos os tipos (Tabela 14). Este resultado está coerente com a afirmação de BOOTH e WINZAR (1993), sobre os alunos do tipo STJ tenderem a apresentar um pior desempenho em situações baseadas na auto-aprendizagem, tendo em vista a possibilidade de os alunos Julgamento terem aproveitado o e-learning para aprimorar esta competência, resultando em uma percepção mais positiva em relação a este aspecto. A média das notas atribuídas pelos alunos STJ para este aspecto foi 7,9 (desvio padrão igual a 1,4) e pelos alunos STP foi 6,4 (desvio padrão igual a 1,6).

É interessante notar que a diferença mais significativa na opinião dos dois tipos mais freqüentes na turma (Intuição/ Sentimento/ Percepção - NFP e Sensação/ Pensamento/ Julgamento - STJ) se refere à adequada substituição da aula presencial pela aula virtual. 
Apesar da grande discordância sobre este aspecto, os alunos do tipo STJ acharam que a substituição foi mais adequada (nota média igual a 5,7 e desvio padrão igual a 2,6), se comparada à opinião dos alunos do tipo NFP (nota média igual a 4,1 e desvio padrão igual a 2,9). Este resultado é importante, já que o STJ é o tipo mais característico da profissão de administrador (MYERS e McCAULLEY 35,1987 apud CASADO, 1998).

Atendendo ao objetivo específico proposto e com base nos resultados discutidos, é possível concluir que o estilo de aprendizagem dos alunos do caso estudado influenciou o desenvolvimento de competências através das atividades de e-learning:

- no caso de alunos com estilo de aprendizagem mais compatível com as atividade de e-learning, foi verificada uma tendência dessas atividades ajudarem no desenvolvimento de competências técnicas (aprendizado da matéria);

- no caso dos alunos com preferências mais divergentes das atividades de $e$ learning, verificou-se uma tendência para estimular o desenvolvimento de competências de aprendizagem e competências sociais.

${ }^{35}$ MYERS, Isabel B.; McCAULLEY, M. H. Manual: a Guide to the Development and Use of the Myers-Briggs Type Indicator. California: Consulting Psychologists Press, 1987. 


\section{CONSIDERAÇÕES FINAIS}

O objetivo geral proposto para este trabalho foi atingido, uma vez que os resultados das pesquisas bibliográfica e empírica indicaram como o e-learning pode contribuir para o desenvolvimento de competências do administrador.

A primeira parte da pesquisa bibliográfica permitiu, através da análise do histórico do ensino da Administração, do currículo de Administração e das competências do administrador, identificar os desafios e demandas atuais da formação do administrador; entre eles, a vinculação do projeto pedagógico à abordagem de competências (NICOLINI, 2002) e a importância do profissional assumir a responsabilidade pelo próprio aprendizado, o que possibilita sua atualização contínua (WICK e LEÓN, 1993; MORAES, 1998).

Em seguida, a parte sobre aprendizagem discutiu o novo paradigma da educação, que considera o processo de aprendizagem efetivo como mais dependente do envolvimento e interação do aluno do que da atuação do professor ou das mídias utilizadas (LIMA, 2000). Dessa forma, o estilo de aprendizagem do aluno, assim como os enfoques teóricos, precisam ser considerados no planejamento das atividades de ensino e dos procedimentos de avaliação, tendo em vista o foco no desenvolvimento de competências.

Por fim, a análise sobre o histórico, os benefícios e problemas e as atividades do elearning, à luz da formação do administrador e do processo de ensino-aprendizagem, indicou que competências do administrador esta metodologia pode estimular, entre elas: competências técnicas, auto-aprendizagem, pesquisa na Internet, comunicação em ambientes virtuais, participação em discussões e formação de comunidades virtuais. O levantamento de literatura sobre o tema, sistematizado no referencial teórico, permitiu ainda colocar algumas questões, como: os instrumentos e teorias de estilo de aprendizagem (que possibilitou a escolha do instrumento utilizado nesta pesquisa), a relação entre o e-learning e as teorias de aprendizagem, os benefícios e problemas do e-learning e a gestão integrada da educação a distância.

Com relação ao primeiro objetivo específico deste trabalho, que consistiu na identificação da contribuição das atividades de e-learning para o desenvolvimento de competências técnicas, os resultados do estudo de caso da disciplina Administração de RH I mostraram que o e-learning, utilizado de forma complementar no curso de graduação da 
FEA/USP, contribuiu de forma positiva para o desenvolvimento dessas competências, principalmente através dos testes auto-corrigidos e da atividade WebQuest.

Apesar desse resultado positivo e respondendo ao segundo objetivo específico, referente à análise da contribuição do e-learning no desenvolvimento de competências de aprendizagem e sociais, é o potencial para auxiliar no desenvolvimento da auto-aprendizagem a contribuição que mais se destaca, tendo em vista a percepção positiva da maioria dos alunos que participaram da pesquisa em relação a esse aspecto. A importância desta questão é reforçada, por se tratar de uma competência essencial para o administrador, conforme mencionado na literatura (WICK e LEÓN, 1993; BASTOS, 1996; MORAES, 1998; SILVA, 1998; AMATUCCI, 2000; BRASIL, 2002). Além disso, enquanto as competências técnicas podem ser desenvolvidas através de diferentes métodos de ensino presenciais, as estratégias para estimular o desenvolvimento da auto-aprendizagem são mais limitadas. Assim, estas considerações reforçam o potencial do e-learning no estímulo a uma cultura de autoaprendizagem, auxiliando na viabilização da educação continuada durante toda a vida, resultado que corrobora com LIMA (2000), PRETI (2000) e MAIA (2001).

Da mesma forma e ainda fazendo referência ao segundo objetivo específico, as competências de atuação em ambientes virtuais são importantes na formação do administrador, tendo em vista a crescente utilização da tecnologia de informação no ambiente corporativo (LÉVY, 1999; PRENCIPE, 2001; SOUKI, ANTONIALLI e SALGADO, 2001), e, também, dificilmente são estimuladas através de métodos de ensino presenciais, sendo mais facilmente desenvolvidas através do e-learning. Apesar das limitações verificadas nesta pesquisa para o desenvolvimento da comunicação em ambientes virtuais, participação em discussões e formação de comunidades virtuais, os resultados indicaram que o e-learning também tem potencial de contribuir nesse sentido, aspecto também observado por MORAN (2000), SPICELAND e HAWKINS (2002), KRETOVICS e McCAMBRIDGE (2002), LANDIS (2001) e ROSENBERG (2002). Para tanto, as atividades propostas precisam ser aprimoradas e o tempo necessário para adaptação do aluno ao ambiente virtual precisa ser considerado, corroborando com os achados de BROWN (2001) e LEWIS (2002).

Com relação ao terceiro objetivo específico deste estudo, os resultados indicaram que o estilo de aprendizagem dos alunos pesquisados influenciou o desenvolvimento de competências obtido com a utilização das atividades de e-learning. 
Ao levar em consideração o estilo de aprendizagem dos alunos, a pesquisa tende a confirmar que não são todas as pessoas que se adaptam ao e-learning, resultando em contribuições diferenciadas dependendo das preferências do aluno. Nesse contexto, o elearning pode ser uma das estratégias de ensino utilizadas, objetivando proporcionar uma formação mais completa aos alunos, através do uso de diferente técnicas de ensino que correspondam às preferências dos alunos e que também desafiem suas limitações, conforme sugerido por BOOTH e WINZAR (1993).

Assim, as competências exigidas do administrador para lidar com os desafios atuais, alinhadas ao potencial verificado do e-learning para contribuir na sua formação, reforçam a necessidade de inserção desta metodologia de ensino na agenda de discussão das Instituições de Ensino Superior.

A decisão de adotar o e-learning por si só não é suficiente para concretizar os benefícios esperados; para tanto, será necessário desenvolver uma cultura de autoaprendizagem, aspecto coerente com as exigências da formação profissional, além de transpor as barreiras existentes no ambiente das Instituições de Ensino Superior, como, por exemplo, a falta de hábito, de conhecimento e afinidade quanto ao uso das tecnologias de e-learning, a necessidade de capacitação dos professores, o conservadorismo e acomodação quanto aos métodos tradicionais de aprendizagem, a disputa por recursos financeiros limitados, a lentidão na tomada de decisões e as leis de propriedade intelectual (LEVINE e SUN, 2002; BRAGA, 2002).

Este processo de mudança não será fácil, considerando que o desafio dos líderes das Faculdades e Universidades atuais está na definição do que precisa ser mudado e na velocidade em que é possível implementar a mudança (KATZ e OBLINGER ${ }^{36}, 2000$ apud TAYLOR, 2003). Assim, enquanto muitas universidades estão tendo dificuldades para chegar a um acordo sobre os desafios relacionados à emergência da necessidade de aprendizagem durante toda a vida, outras têm desempenhado um papel significativo na educação a distância, mantendo-se na vanguarda da inovação e da mudança institucional (TAYLOR, 2003).

É importante lembrar que os resultados deste trabalho estão atrelados às escolhas metodológicas realizadas em função do caráter exploratório do estudo, através do qual

\footnotetext{
${ }^{36}$ KATZ, R.N.; OBLINGER, D.G. (Eds.). The “E” is for everything: e-Commerce, e-Business and eLearning in the future of higher education. San Francisco: Jossey-Bass, 2000.
} 
buscou-se obter maior conhecimento sobre o tema (MATTAR 1999), não podendo ser generalizados. Dentre as principais escolhas metodológicas é possível citar:

- Estudo de caso único;

- As atividades de e-learning propostas, que não podem ser comparadas a outros formatos de atividades utilizando os mesmos recursos ou mídias;

- A amostra não probabilística;

- A utilização de questionários auto-preenchidos, que geram um viés do respondente quanto às informações relatadas;

- Ausência da etapa de validação dos instrumentos utilizados (exceto o Inventário Brasileiro para Diagnóstico das Diferenças Individuais), tendo em vista a limitação de tempo e recursos;

- A escala ordinal utilizada no questionário de avaliação, assumida como intervalar para realização de cálculos estatísticos adicionais;

- As análises referentes ao aprendizado da matéria e desenvolvimento de competências, baseadas na percepção do aluno;

- Grupo atípico de respondentes em relação ao perfil esperado do administrador, no que se refere às preferências individuais, analisadas através do tipo psicológico.

Além disso, o estudo em ciências sociais está fortemente condicionado à imprevisibilidade dos fenômenos humanos, assim como a sua dificuldade de quantificação. De forma complementar, o tema ensino-aprendizagem é altamente complexo, sendo necessária uma simplificação para realização das análises, e o conceito de competência de formação utilizado limita-se à formação desejada do profissional, tendo em vista uma situação de trabalho futura.

Por fim, outra limitação se refere ao viés do pesquisador, que influenciou o estudo através da escolha da metodologia, da análise dos resultados e da participação ativa no caso estudado.

Este estudo também cumpre seu papel no que se refere à formulação de hipóteses e insights para pesquisas futuras, tendo em vista seu caráter exploratório. Sendo assim, a primeira sugestão para pesquisas futuras seria a realização de uma pesquisa conclusiva, com o objetivo de verificar as hipóteses discutidas no capítulo da análise de resultados. 
Também poderiam ser exploradas outras atividades de e-learning, como o estudo de caso através da Internet e a colaboração com alunos de localidades distantes, com potencial para desenvolver outras competências do administrador (que não foram analisadas neste trabalho), como resolução de problemas e relacionamento com pessoas de culturas diferentes.

A questão da avaliação da aprendizagem voltada para a abordagem por competências também precisaria ser estudada, assim como os procedimentos de avaliação no contexto do $e$ learning.

Outro caminho para aprofundamento do tema seria a adaptação de atividades pedagógicas em função do estilo de aprendizagem dos alunos, com o objetivo de obter melhores resultados quanto ao desenvolvimento de competências do administrador. Considerando outro enfoque do conceito de estilo de aprendizagem, poderia ser estudado o impacto das preferências individuais dos professores de administração no delineamento e realização das atividades de e-learning. Ampliando um pouco o foco, a hipótese sobre a influência dos tipos psicológicos no preenchimento de instrumentos de avaliações de cursos poderia ser investigada, fornecendo informações importantes para o processo de aprimoramento das técnicas de ensino.

Por fim, pesquisas sobre as barreiras e facilitadores envolvidos na implantação de atividades de e-learning do ponto de vista da Instituição de Ensino Superior, assim como o processo de gestão da mudança que se faz necessário, também contribuiriam para o avanço do conhecimento sobre o tema. 


\section{REFERÊNCIAS BIBLIOGRÁFICAS}

AAKER, David A.; DAY, George S. Marketing Research. 4. ed. New York: Wiley, 1990. $739 \mathrm{p}$.

AIEC - Associação Internacional de Educação Continuada, Faculdade de Administração de Brasília. Disponível em: <http://www.aiec.br>. Acesso em: 21 jun. 2003.

AMATUCCI, Marcos. Perfil do administrador brasileiro para o Século XXI: um enfoque metodológico. 2000. 295 f. Tese (Doutorado em Administração) - Faculdade de Economia, Administração e Contabilidade, Universidade de São Paulo, São Paulo, 2000.

ANDRADE, Rui Otávio Bernardes de. História e Perspectiva dos Cursos de Administração no Brasil. CFA - Conselho Federal de Administração. Disponível em: $<$ http://www.cfa.org.br>. Acesso em: 23 nov. 2002.

ANDRADE, Rui Otávio Bernardes de; LIMA, Manolita Correia; TORDINO, Cláudio Antônio. O Que Podemos Aprender com os Cursos 5A? São Paulo: Makron Books, 2001. $196 \mathrm{p}$.

ANGRAD - Associação Nacional dos Cursos de Graduação em Administração. Pesquisa PHAD/96: Perfil e Habilidades do Administrador. 1996. Disponível em: $<$ http://www.angrad.com/angrad/phad96.pdf>. Acesso em: 23 nov. 2002.

ARAÚJO, José Carlos Souza. Para uma Análise das Representações sobre as Técnicas de Ensino. In: VEIGA, Ilma Passos Alencastro (org.). Técnicas de Ensino: por que não? Campinas: Papirus, 2001. 149 p.

ARBAUGH, J. B. How classroom environment and student engagement affect learning in Internet-based MBA courses. Business Communication Quarterly, New York, v. 63, n. 4, p. 9-26, dez. 2000.

ATHABASCA UNIVERSITY. Study Compares Student-to-Student Classroom and Online Learning. Toronto, 21 abr. 2001. Disponível em: <http:/www.athabascau.ca/ media/ivey.htm>. Acesso: 2 maio 2003. 
BARBOSA, Fernando Fontes. Estilos de ensino e aprendizagem. EGATEA DIGITAL Revista da Escola de Engenharia/Universidade Federal do Rio Grande do Sul. Disponível em: $<$ http://www.ufrgs.br/eng/egatea/>. Acesso em: 26 ago. 2002.

BASTOS, Antonio Virgílio Bittencourt. A Escolha e o Comprometimento com a Carreira: Um Estudo entre Profissionais e Estudantes de Administração. In: ENCONTRO ANUAL DA ANPAD, 20., 1996, Angra dos Reis. Anais... v. 8, 1996. p. 29-44.

BEEBE, Thomas H.; RILEY, Peter C. Development of a Mult-media Course for the World Wide Web. In: Orlando multimedia'97 - Society for Applied Learning Technology. Warrenton, VA: SALT, 1997.

BERNDT, Alexander. Qual o Sentido do Currículo Mínimo?. In: Encontro ANUAL DA ANPAD, 20., 1996, Angra dos Reis. Anais... v. 8, 1996. p. 57-66.

BIGGE, Morris L. Teorias da Aprendizagem para Professores. São Paulo: E.P.U./EDUSP, 1977. $370 \mathrm{p}$.

BOK, Derek. Ensino Superior. Trad. José Livio Dantas. Rio de Janeiro: ForenseUniversitária, 1988. $231 \mathrm{p}$.

BONHAM, L. Adrianne. Using Learning Styles Information, Too. In: HAYES, E.R. (ed.). New Directions for Continuing Education, n. 43. São Francisco: Jossey-Bass, 1989. p. 2940.

BOOTH, Peter; WINZAR, Hume. Personality Biases of Accounting Students: Some Implications for Learning Style Preferences. Accounting and Finance, Clayton , v.33, n.2, nov. 1993. p.109-120.

BORDENAVE, Juan Díaz; PEREIRA, Adair Martins. Estratégias de EnsinoAprendizagem. 15. ed. Petrópolis: Vozes, 1995. 312 p.

BOSTROM, Robert P.; OLFMAN, Lorne; SEIN, Maung K. Learning styles and end-user training: A first step. MIS Quarterly, v. 17, n. 1, mar. 1993. p. 118.

BOTELHO, Marco Antônio R. A Universidade Além da Sala de Aula. e-Manager, ano 3, n. 26, p.12, mar. 2002. 
BOYD, Barry L.; MURPHREY, Theresa P. Evaluating of Computer-Based Asynchronous Activity on Student Learning of Leadership Concepts. Journal of Agricultural Education, v. 43, n.1, p.36-45, 2002.

BRAGA, Ryon. O E-learning e o Marketing nas Instituições de Ensino. Revista Aprender Virtual, ano 2, n. 3, p. 58-61, maio/jun. 2002.

BRASIL. Decreto $\mathrm{n}^{\circ}$ 2494, de 10 de fevereiro de 1998. Regulamenta o Art. 80 da LDB (Lei n ${ }^{\circ}$ 9394/96). Diário Oficial da União, Brasília, DF, 11 fev. 1998. Disponível em: $<$ http://www.mec.gov.br/Sesu/ftp/dec_2494.doc>. Acesso em: 2 jul. 2003.

BRASIL. Parecer CNE/CES 146/2002, de 3 de abril de 2002. Diretrizes Curriculares Nacionais dos cursos de graduação em Direito, Ciências Econômicas, Administração, Ciências Contábeis, Turismo, Hotelaria, Secretariado Executivo, Música, Dança, Teatro e Design. Diário Oficial [da República Federativa do Brasil], n. 90, Poder Executivo, Brasília, DF, 13 maio 2002. Disponível em: <http://www.mec.gov.br/sesu/ftp/pareceres/ 14602DCEACTHSEMDTD.doc $>$ Acesso em 29 out. 2002.

BRASIL. Portaria $\mathrm{n}^{0}$ 2253, de 18 de outubro de 2001. Diário Oficial da União, Brasília, DF, 19 out. 2001. Seção1, p.18.

BROWN, George; ATKINS, Madeleine. Effective Teaching in Higher Education. London: Routledge, 1997.

BROWN, Ruth E. The Process of Community-Building in Distance Learning Classes. Journal of Asynchronous Learning Networks - JALN, v. 5, n. 2, set. 2001. Disponível em: $<$ http://www.aln.org $>$. Acesso em: 02 maio 2003.

CAFARDO, Renata. MEC aposta na educação superior a distância. O Estado de S. Paulo, São Paulo, 4 maio 2003. Geral/Educação, p. A 14.

CAMPOS, Stela. Depois de tantos erros, a hora é de refletir sobre o melhor uso do ensino a distância. Valor Econômico, São Paulo, 20 nov. 2002.

CARDOSO, Sonia Maria Vicente; JANDL Jr., Peter. Estilos de Aprendizagem: aprendendo a aprender. Direito-USF, v.15, n.2, p. 135-145, 1998. Disponível em: <http://sites.uol.com.br/ jandl/artigos/Estilos.pdf>. Acesso em 26 ago. 2002. 
CAROLEI, Paula. Alquimia e Novas Tecnologias: A busca da Grande Obra do EnsinoAprendizagem. 2002. 179 f. Dissertação (Mestrado em Educação) - Faculdade de Educação, Universidade Estadual de Campinas - UNICAMP, Campinas, 2002. Disponível em: $<$ http://www.rau-tu.unicamp.br>. Acesso em: 21 mar. 2003.

CASADO, Tânia. Comunicação Interpessoal: trabalhando com os Tipos Psicológicos. In: Varejo - Perspectivas. São Paulo: Editora Atlas, 1994.

. Tipos Psicológicos: Uma Proposta de Instrumento para Diagnóstico do Potencial Humano nas Organizações. 1998. 171 f. Tese (Doutorado em Administração) - Faculdade de Economia, Administração e Contabilidade, Universidade de São Paulo, São Paulo, 1998.

. Tipos Psicológicos e Estilos de Comportamento Motivacional: o Diálogo entre Jung e Fromm. 1993. 135 f. Dissertação (Mestrado em Administração) - Faculdade de Economia, Administração e Contabilidade, Universidade de São Paulo, São Paulo, 1993.

CAVEDON, Neusa Rolita; RECH, Carla Regina Nedel; CANO, Carlos Baldessarini. "Ensino a Distância": a Experiência da Escola de Administração da Universidade Federal do Rio Grande do Sul. Disponível em: <http://read.adm.ufrgs.br>. Acesso em: 22 nov. 2002.

CERRI, Cristina; BARUFI, Maria Cristina Bonomi. Oferecimento de Cálculo Diferencial e Integral III Usando o WebCT. Relatório Técnico. Departamento de Matemática, Instituto de Matemática e Estatística da Universidade de São Paulo, mar. 2001.

CFA - Conselho Federal de Administração. Perfil, Formação e Oportunidades de Trabalho do Administrador Profissional, 1998. Disponível em: <http://www.cfa.org.br>. Acesso em: 23 nov. 2002.

CHAGAS, Anivaldo T. R. Dimensões de Ensino em Sala de Aula de Administração: um estudo sobre as preferências dos alunos. 2002. 243 f. Tese (Doutorado em Administração) Faculdade de Economia, Administração e Contabilidade, Universidade de São Paulo, São Paulo, 2002.

CHAVES, Maria Cecília S. Atuando como moderador on-line. In: Curso E-learning: Educando em Ambientes Virtuais, realizado na FEA/USP, São Paulo, 2001.

CHOU, C. Candace. Model of Learner-Centered Computer-Mediated Interaction for Collaborative Distance Learning. In: NATIONAL CONVENTION OF THE ASSOCIATION FOR EDUCATIONAL COMMUNICATIONS AND TECHNOLOGY, 24, 2001, Atlanta, Proceedings... 2001. Disponível em: < http://www.ericit.org/fulltext/IR021523.pdf > Acesso em 28 mar. 2003. 
CLAXTON, Charles S.; MURRELL, Patricia H. Learning Styles. ERIC Digest, Washington, 1988. Disponível em: <http://ericae.net/edo/ED301143.htm>. Acesso em 13 out. 2002.

COMINI, Graziela Maria; LIMA, Manoelita Correia. Revisão Curricular dos Cursos de Administração: balanço e desafios. In: ENCONTRO ANUAL DA ANPAD, 20., 1996, Angra dos Reis, Anais... 1996. v. 8, p.135-149.

COMISSÃO ASSESSORA PARA EDUCAÇÃO SUPERIOR A DISTÂNCIA. Relatório, ago. 2002. Disponível em: <http://www.vad.com.br/relatorio_ead.pdf $>$. Acesso em: 24 jan. 2003.

COVRE, Maria de Lourdes Manzini. A Formação e a Ideologia do Administrador de Empresa. Petrópolis: Vozes, 1981.

DELORS, Jacques (org.). Educação: um tesouro a descobrir. 3. ed. São Paulo: Cortez; Brasília: MEC/UNESCO, 1999. 288p.

DODGE, Bernie. Webquest: uma técnica para aprendizagem na rede Internet. Trad. Jarbas Novelino Barato. The Distance Educator, v.1, n.2, 1995. Disponível em: $<$ http://webquest.futuro.usp.br/artigos/textos_bernie.html> Acesso em: 23 abr. 2003.

DRUCKER, Peter. e-ducação. Exame. São Paulo: Editora Abril, p. 64-67, 14 jun. 2000.

DUTRA, J. S. Gestão por Competências: um modelo avançado para o gerenciamento de pessoas. São Paulo: Ed. Gente, 2001.

DUTTON, John; DUTTON, Marilyn; PERRY, Jo. How Do Online Students Differ from Lecture Students? Journal of Asynchronous Learning Networks - JALN, v. 6, n. 1, jul. 2002. Disponível em: <http://www.aln.org>. Acesso em: 02 maio 2003.

EAESP/FGV - Escola de Administração de Empresas de São Paulo da Fundação Getúlio Vargas. Disponível em: < http://www.gv.br/nova_intranet/CaseStatment.pdf $>$ Acesso em: 24 nov. 2002.

EBAPE/FGV - Escola Brasileira de Administração Pública e de Empresas da Fundação Getúlio Vargas. Disponível em: <http://www.ebape.fgv.br>. Acesso em: 24 nov. 2002.

EXAME NACIONAL DE CURSOS. Disponível em: $<$ http://web.inep.gov.br/enc/resultados/>. Acesso em: 25 nov. 2002. 
FEA - Faculdade de Economia, Administração e Contabilidade da Universidade de São Paulo. Disponível em: <http://www.fea.usp.br> Acesso em: 24 jun. 2003.

FELDER, Richard M. Reaching the Second Tier: Learning and Teaching Styles in College Science Education. J. College Science Teaching, v. 23, n. 5, p. 286-290, 1993. Disponível em <http://www2.ncsu.edu/unity/lockers/users/f/felder/public/Papers/ Secondtier.html $>$. Acesso em: 27 ago. 2002.

FERRARI, Afonso Trujillo. Metodologia da pesquisa científica, São Paulo: McGraw-Hill do Brasil, 1982. 318 p.

FINN, Amy. Trends in E-Learning. Learning Circuits. 25 nov. 2002. Disponível em: $<$ http://www.learningcircuits.org/2002/nov2002/finn.htm >. Acesso em: 21 fev. 2003.

FLEURY, Afonso; FLEURY, Maria Tereza Leme. Estratégias Empresariais e Formação de Competências: Um Quebra-Cabeça Caleidoscópico da Indústria Brasileira. 2. ed. São Paulo: Editora Atlas, 2001. 169 p.

FLEURY, Maria Tereza Leme; OLIVEIRA Jr., Moacir de Miranda. Aprendizagem e gestão do conhecimento. In: FLEURY, Maria Tereza Leme (org.). As pessoas na organização. São Paulo: Gente, 2002. 306 p.

FONTANA, Andrea; FREY, James H. Interviewing: The Art of Science. In: DENZIN, Norman K.; LINCOLN, Yvonna S. Handbook of Qualitative Research, London: Sage Publications, 1994. p.361-376.

FORMIGA, Marcos. Educação ao Longo da Vida e Educação a Distância. Galáxia. São Paulo: Associação Brasileira de Educação a Distância (ABED), p.3, jun./jul. 2002.

FREDERICKSEN, Eric et al. Student Satisfaction and Perceived Learning with On-line Courses: Principles and Examples from the SUNY Learning Network. Journal of Asynchronous Learning Networks - JALN, v. 4, n. 2, set. 2000. Disponível em: $<\mathrm{http}: / / \mathrm{www}$.aln.org/ publications/jaln/v4n2/pdf/v4n2_fredericksen.pdf $>$. Acesso em: 5 maio 2003 .

FRYDENBERG, Jia. Quality Standards in eLearning: A Matrix of Analysis. International Review of Research in Open and Distance Learning, out. 2002. Disponível em: http://www.irrodl.org/content/v3.2/frydenberg.html>. Acesso em: 13 maio 2003.

FUVEST - Fundação Universitária para o Vestibular. Disponível em: <www.fuvest.br>. Acesso em: 25 nov. 2002. 
GAGNÉ, Robert M. Como se Realiza a Aprendizagem. 2. ed. Trad. Therezinha Maria Ramos Tovar. Rio de Janeiro: Livros Técnicos e Científicos Editora, 1974.

GODOY, Arilda Schmidt. Avaliação da Aprendizagem no Ensino Superior: Esta da Arte. Didática, n.30, p.9-25, 1995.

Recursos Tecnológicos e Ensino Individualizado. (b) In: MOREIRA, Daniel Augusto (org.). Didática no Ensino Superior: Técnicas e Tendências, São Paulo: Editora Pioreira, 1997, p.101-113.

. Revendo a Aula Expositiva. (a) In: MOREIRA, Daniel Augusto (org.). Didática no Ensino Superior: Técnicas e Tendências, São Paulo: Editora Pioreira, 1997, p.75-82.

GODOY, Arilda Schmidt; CUNHA, Maria Alexandra V. C. da. Ensino em Pequenos Grupos. In: MOREIRA, Daniel Augusto (org.). Didática no Ensino Superior: Técnicas e Tendências, São Paulo: Editora Pioreira, 1997, p.83-100.

GOMES, Maria Lúcia Moreira. Piaget/Vygostsky e as Novas Tecnologias: Uma Interface Possível. Revista iColetiva - Núcleo de Inteligência Coletiva Aplicada à Educação (NICE), jun. 2003. Disponível em: <http://www.icoletiva.com.br>. Acesso em: 3 jun. 2003.

GORDON, Wendy; LANGMAID, Roy. Qualitative Market Research: A Practitioner's and Buyer's Guide, England: Gower, 1988.

GRIGGS, Shirley A. Learning Styles Counseling. ERIC Digest, dez. 1991. Disponível em: <http://www.ed.gov/databases/ERIC_digests/ed341890.html>. Acesso em 13 out. 2002.

GU, Wei. Online Education Attracts Students and Profits. Reuters, New York, 4 jun. 2003. Disponível em: http://asia.reuters.com/newArticle.jhtml?type=internetNews\&storyID=2878435 Acesso em: 5 jun. 2003.

GUERRA, Elaine Linhares de Assis. O Ensino Superior de Administração no Brasil: desafios do novo milênio. In: ENANGRAD, 12., 2001. São Paulo. Anais... 2001. Disponível em: $<$ http://www.angrad.com/artigos_xii_enangrad.asp>. Acesso em: 19 nov. 2002.

GUNN, Cathy. Effective Online Teaching - How Far do the Frameworks Go? In: ASCLITE 2001 - Annual Conference of the Australasian Society for Computers in Learning in Tertiary Education, 18., 2001. Melbourne. Proceedings... 2001. Disponível em: $<$ http://www.ericit.org/ fulltext/IR021460.pdf>. Acesso em: 17 jun. 2003. 
HARA, Noriko; KLING, Rob. Students' frustrations with a web-based distance education course. First Monday, v. 4, n. 12, dez. 1999. Disponível em: $<\underline{\text { http://www.firstmonday.dk/ }}$ issues/issue4_12/hara/index.html>. Acesso em 10 out. 2002.

HEINEMAN, Peter L. Cognitive Versus Learning Style. 1995. Disponível em: $<$ http://www.personality-project.org/perproj/others/heineman/cog.htm>. Acesso em: 13 out. 2002.

HILTZ, Starr Roxanne. The virtual classroom: learning without limits via computer networks. New Jersey: Ablex Publishing Corporation, 1994.

HUTCHINS, Holly M. Enhancing the business communication course through WebCT. Business Communication Quarterly, New York, v.64, n.3, p.87-94, set. 2001.

IDORT. Disponível em: <http://www.arquivo.ael.ifch.unicamp.br/acer-fund-idort.htm> Acesso em: 26 nov. 2002.

INEP - Instituto Nacional de Estudos e Pesquisas Educacionais Anísio Teixeira. Sinopse Estatística da Educação Superior Graduação (dados de 2001), 2002. Disponível em $<$ http://www.inep.gov.br/superior/censosuperior/sinopse/default.asp $>$. Acesso em: 26 nov. 2002.

INEP NOTÍCIAS. Educação Superior recebe 3,8 milhões de alunos em seis anos. 21 nov. 2001. Disponível em: <http://www.inep.gov.br/imprensa>. Acesso em: 26 nov. 2002.

INEP NOTÍCIAS. Educação Superior ultrapassa meta e chega a três milhões de matrículas. 20 nov. 2002. Disponível em: <http://www.inep.gov.br/imprensa>. Acesso em: 26 nov. 2002.

IUVB.BR. Disponível em: <http://www.iuvb.edu.br>. Acesso em: 27 jun. 2003.

JACOBSOHN, Liliana Vasconcellos; ALVES, Flávia Helena Dante; ÉBOLI, Marisa; FISCHER, André Luiz. A Utilização do WebCT em um Curso de Pós-Graduação: combinando ensino presencial e ensino a distância. In: ENANPAD 2002 - Encontro da Associação Nacional do Programas de Pós-graduação em Administração (ANPAD), 26., 2002, Salvador. Anais... Rio de Janeiro: ANPAD, 2002. 1 CD-ROM. 
JOHNSON, Kerry A.; FOA, Lin J. Instructional Design: New Alternatives for Effective Education and Training. New York: American Council on Education and Macmillan Publishing Company, 1989.

JOY, Ernest H.; GARCIA, Federico E. Measuring Learning Effectiveness: A New Look at No-Significant-Difference Findings. Journal of Asynchronous Learning Networks JALN, v. 4, n. 1, jun. 2000. Disponível em: <http://www.aln.org>. Acesso em: 02 maio 2003.

KARUPPAN, Corinne M. Web-based teaching materials: a user's profile. Internet Research, Bradford, v.11, n. 2, p.138-148, 2001.

KASHY, Deborah A.; ALBERTELLI II, Guy; BAUER, W.; KASHY, E.; THOENNESSEN, M. Influence of Non-Moderated and Moderated Discussion Sites on Student Success. Journal of Asynchronous Learning Networks - JALN, v. 7, n. 1, fev. 2003. Disponível em: $<\mathrm{http}$ ://www.aln.org $>$. Acesso em: 02 maio 2003.

KHAN, Badrul H (Ed.). Web-based instruction. Englewood Cliffs: New Jersey, 1997.

KOLB, David A. Experiential Learning: Experience as The Source of Learning and Development. New Jersey: Prentice Hall P T R, Englewood Cliffs, 1984.

KOLB, David A.; RUBIN, Irwin M.; McINTYRE, James M. Psicologia Organizacional: Uma Abordagem Vivencial. Trad. Edi Gonçalves de Oliveira. São Paulo: Editora Atlas, 1978.

KRETOVICS, Mark; McCAMBRIDGE, Jim. Measuring MBA Student Learning: Does Distance Make a Difference? International Review of Research in Open and Distance Learning - Athabasca University, v.3, n.2, out. 2002. Disponível em: $<\mathrm{http}$ //www.irrodl.org/content/v3.2/kretovics.html>. Acesso em: 13 maio 2003.

LANDIS, Melodee. A Comparison of Interaction in AV-based and Internet-based Distance Courses. Journal of International Forum of Educational Technology \& Society, v. 4, n. 4, abr. 2001. Disponível em: <http://ifets.ieee.org> Acesso em: 14 maio 2003.

LEH, Amy S. C. Action Research on Building Learning Communities in Cyberspace. In: National Convention of the Association for Educational Communications and Technology, 24., Atlanta, Georgia, 2001. Anais... California, 2001. Disponível em: $<$ http://www.ericit.org/fulltext/IR021591.pdf > Acesso em: 29 abr. 2003.

LEVINE, Arthur; SUN, Jeffrey C. Barriers to Distance Education. Washington: American Council on Education, 2002. Disponível em <http://www.acenet.edu/bookstore/ pdf/distributed-learning/distributed-learning-06.pdf>. Acesso em: 24 abr. 2003 
LÉVY, Pierre. Cibercultura. Trad. Carlos Irineu da Costa. 2. ed. São Paulo: Ed. 34, 1999.

LEWIS, Barbara A. The Effectiveness of Discussion Forums in On-line Learning. Revista Brasileira de Aprendizagem Aberta a Distância - Associação Brasileira de Educação a Distância (ABED), v. 1, n. 1. ago. 2002. Disponível em: <http://www.abed.org.br>. Acesso em: 6 maio 2003.

LIMA, Frederico O. A Sociedade Digital: o impacto da tecnologia na sociedade, na cultura, na educação e nas organizações. Rio de Janeiro: Qualitymark Ed., 2000.

LITTO, Frederic M. Jornal da USP. São Paulo: Universidade de São Paulo - Coordenadoria da Comunicação Social, ano XVIII, n. 639, 22 a 27 abr. 2003, Opinião, p.2.

LITWIN, Edith. La Educación a Distancia en la Educación del Futuro: Desafíos, Recurrencias y Perspectivas. In: MENA, Marta (coord.). ICDE: Presente y Futuro de la Educación a Distancia en América Latina y El Caribe. Seminario de Educación a Distancia para América Latina y El Caribe, Buenos Aires - México, out. 1998. Buenos Aires: Universidad de Buenos Aires/Facultad de Ciencias Económicas, 1999. 240 p.

LOPES, Paulo da Costa. Reflexões sobre as Bases da Formação do Administrador Profissional no Ensino de Graduação. In: ENANPAD 2002 - Encontro da Associação Nacional do Programas de Pós-graduação em Administração (ANPAD), 26., 2002, Salvador. Anais... Rio de Janeiro: ANPAD, 2002. 1 CD-ROM.

LOPES, Wilma Maria Guimarães. ILS - Inventário de Estilos de Aprendizagem de FelderSaloman: Investigação de sua Validade em Estudantes Universitários de Belo Horizonte. 2002. Dissertação (Mestrado) - Centro Tecnológico / Departamento de Engenharia de Produção e Sistemas, Universidade Federal de Santa Catarina (UFSC), Florianópolis, 2002.

LUZ, Talita Ribeiro da. Competências Gerenciais Requeridas em Ambientes de Mudança. In: ENANGRAD, 9. 1998, Itu. Anais... 1998. Disponível em: <www.angrad.com/ artigos_ix_enangrad.asp>. Acesso em: 19 nov. 2002.

MAIA, Carmem. Guia Brasileiro de Educação a Distância. São Paulo: Editora Esfera, 2001.

MARCH, Tom. WebQuest for learning: Why webquests? An introduction, Ozline.com Helping Educators Work the Web, set. 1998. Disponível em: $<$ http://www.ozline.com/webquests/ intro.html> Acesso em: 24 abr. 2003.

MARTINS, Carlos Benedito. Notas sobre o sistema de ensino superior brasileiro contemporâneo. REVISTA USP, São Paulo, n. 34, p. 59-82, set./nov. 1989. 
MARTINS, Gilberto de Andrade. Estatística Geral e Aplicada. São Paulo: Editora Atlas, 2001 .

MARTINS, Eliseu; FLEURY, Maria Tereza Leme (coord.). Workshop “A FEA/USP e a Crise da Universidade”, São Paulo: FEA/USP, 2000. 55 p.

MATTAR, Fauze Najib. Pesquisa de Marketing: execução e análise. v. 2. 2. ed. São Paulo: Editora Atlas, 1998. 224 p.

Pesquisa de Marketing: metodologia e planejamento. v. 1. 5. ed. São Paulo: Editora Atlas, $1999.337 \mathrm{p}$.

MEC - Ministério da Educação. Disponível em: <http://www.mec.gov.br>. Acesso em: 27 jun. 2003.

MEYER, Katrina A. The Web's Impact On Student Learning. THE Journal Online Technological Horizons in Education, maio 2003. Disponível em: $<$ http://www.thejournal.com/ magazine/vault/A4401.cfm>. Acesso em: 13 maio 2003.

MONTGOMERY, Susan M. Addressing Diverge Learning Styles Through the Use of Multimedia. Teaching at an Internet Distance - University of Illinois. out. 1995. Disponível em <http://www.vpaa.uillinois.edu/reports_retreats/tid/resources/montgomery.html $>$. Acesso em 20 jun. 2002.

MOORE, Michael G. Teoria da Distância Transacional. Trad. Wilson Azevedo. Revista Brasileira de Aprendizagem Aberta a Distância - Associação Brasileira de Educação a Distância (ABED), v. 1, n. 1. ago. 2002. Disponível em: <http://www.abed.org.br>. Acesso em: 6 maio 2003.

MORAES, Ana Shirley de França. Universidade e Formação de Recursos Humanos: Características Culturais Básicas na Formação de Competências. In: ENANGRAD, 9. 1998, Itu. Anais... 1998. Disponível em: <www.angrad.com/artigos_ix_enangrad.asp>. Acesso em: 19 nov. 2002.

MORAN, José Manuel. Ensino e aprendizagem inovadores com tecnologias digitais. In: MORAN, José Manuel; MASETTO, Marcos; BEHRENS, Marilda. Novas Tecnologias e Mediação Pedagógica. São Paulo: Papirus Editora, 2000.

MOREIRA, Marco Antonio. Teorias de Aprendizagem. São Paulo: EPU, 1999. 
MORGAN, Brian M. Is Distance Learning Worth It? Helping to Determine the Costs of Online Courses. Marshall University, 2003. Disponível em: <http://www.marshall.edu/ distance/distancelearning.pdf $>$ Acesso em: 23 abr. 2003.

MORRIS, D.; MITCHELL, N.; BELL, M. Student Use of Computer-Mediated Communication in an Open University Level 1 Course: Academic or Social? Journal of Interactive Media in Education, v. 99, n.2, 1999. Disponível em: <http://wwwjime.open.ac.uk/99/2/morris-99-2-paper.html>. Acesso em: 7 maio 2003.

MOURA, Ana Maria M. de; AZEVEDO, Ana Maria P. de; MEHLECKE, Querte. As Teorias de Aprendizagem e os Recursos da Internet Auxiliando o Professor na Construção do Conhecimento. Associação Brasileira de Educação a Distância (ABED), set. 2002. Disponível em: <http://www.abed.org.br>. Acesso em: 16 maio 2003.

MUELLER, Rafael Rodrigo. Webquest: Desenvolvendo a autonomia através da pesquisa na Web. Projeto WebQuest - Escola do Futuro da USP, 2002. Disponível em: $<$ http://www.webquest.futuro.usp.br/artigos/textos_rafael.html> Acesso em: 24 abr. 2003.

MUMFORD, Alan; HONEY, Peter. Questions and Answers on Learning Styles Questionnaire. Industrial and Commercial Training, Guilsborough, v. 24, n. 7, p.10, 1992.

MURRAY, Peter J.; MASON, Robin. Computer-Mediated Communication (CMC): state of the art. Revista Brasileira de Aprendizagem Aberta a Distância - Associação Brasileira de Educação a Distância (ABED), v. 1, n. 2. jan. 2003. Disponível em: $<$ http://www.abed.org.br>. Acesso em: 6 maio 2003.

MYERS, Isabel B.; McCAULLEY, M.H. Manual: a Guide to the Development and Use of the Myers-Briggs Type Indicator. California: Consulting Psychologists Press, 1987.

NICOLINI, Alexandre. O Futuro Administrador pela Lente das Novas Diretrizes Curriculares: Cabeças "Bem-Feitas" ou "Bem Cheias"?. In: ENANPAD 2002 - Encontro da Associação Nacional do Programas de Pós-graduação em Administração (ANPAD), 26., 2002, Salvador. Anais... Rio de Janeiro: ANPAD, 2002. 1 CD-ROM.

NORONHA, Adriana Backx; VIEIRA, Amanda Ribeiro. O Uso da Plataforma WebCT como Ferramenta de Apoio ao Ensino de Estatística para o Curso de Graduação em Administração. Revista ANGRAD - Associação Nacional dos Cursos de Graduação em Administração, v.3, n.4, p.86-97, out./dez. 2002.

NUNES, Ivônio Barros. Noções de Educação a Distância. Revista Educação a Distância. Brasília, Instituto Nacional de Educação a Distância n. 4/5, p. 7-25, dez. 1993/ abr. 1994. Disponível em: <http://www.intelecto.net/ead_textos/ivonio1.html>. Acesso em 9 set. 2001. 
O ENSINO a distância ainda não pegou. Carta Capital, São Paulo: Editora Confiança, ano IX, n. 232, p.43, 19 mar. 2003.

OLIVER, Martin; SHAW, Graham P. Asynchronous Discussion in Support of Medical Education. Journal of Asynchronous Learning Networks - JALN, v. 7, n. 1, fev. 2003. Disponível em: <http://www.aln.org > . Acesso em: 2 maio 2003.

ONLINE Classes Provide Better Way to Teach Global Education, Researcher Says. Ascribe The Public Interest Newswire, Ohio, 13 maio 2003. Disponível em: $<$ http://www.ascribe.org $>$. Acesso em: 14 maio 2003.

OSIN, Luis. La Tecnología al Servicio de la Pedagogía. In: MENA, Marta (coord.). ICDE: Presente y Futuro de la Educación a Distancia en América Latina y El Caribe. Seminario de Educación a Distancia para América Latina y El Caribe, Buenos Aires - México, out. 1998. Buenos Aires: Universidad de Buenos Aires/Facultad de Ciencias Económicas, 1999. $240 \mathrm{p}$.

OSORIO, J.; RUBIO-ROYO, E.; OCÓN, A. Virtual Classroom for Business Planning Formulation. In: EUNIS '99 - European University Information Systems International Conference, 5., 1999, Finlândia. Proceedings... 1999. Disponível em: $<$ http://ericit.org/fulltext/ IR020642.pdf>. Acesso em 12 maio 2003.

PAIVA, Wagner Peixoto. Avaliação de Habilidades para a Tomada de Decisão em Administração de Empresas: Um Estudo com Alunos de Graduação da FEA-USP. 2002. 115 f. Dissertação (Mestrado em Administração) - Faculdade de Economia, Administração e Contabilidade, Universidade de São Paulo, São Paulo, 2002.

PANTAZIS, Cynthia. Maximizing e-learning to train the 21st century workforce. Public Personnel Management, v.31, n.1, Washington, 2002.

PARKER, Drew; GEMINO, Andrew. Inside Online Learning: Comparing Conceptual and Technique Learning Performance in Place-Based and ALN Formats. Journal of Asynchronous Learning Networks - JALN, v. 5, n. 2, set. 2001. Disponível em: $<\mathrm{http}$ //www.aln.org>. Acesso em: 02 maio 2003.

PEREIRA, Júlio César Rodrigues. Análise de Dados Qualitativos: Estratégias Metodológicas para as Ciências da Saúde, Humanas e Sociais. São Paulo: EDUSP: FAPESP, 1999. $156 \mathrm{p}$.

PERRENOUD, Philippe. Construir as Competências desde a Escola. Trad. Bruno Charles Magne. Porto Alegre: Artes Médicas Sul, 1999. 90 p. 
PRAMMANEE, Noppadol. Understanding Participation in Online Courses: A Case Study of Perceptions of Online Interaction. Department of Educational Technology, Research and Assessment - College of Education, Northern Illinois University, DeKalb, mar. 2003. Disponível em: <http://it.coe.uga.edu/itforum/paper68/paper68.html>. Acesso em: 24 mar. 2003.

PRENCIPE, L. W. Do you know the rules and manners of an effective virtual meeting? InfoWorld, Framingham, 30 Apr , 2001.

PRETI, Oreste. Autonomia do Aprendiz na Educação a Distância: significados e dimensões, 2000. Disponível em: <http://www.nead.ufmt.br/documentos/autonomia__oreste_I07.doc > Acesso em: 23 abr. 2003.

PricewaterhouseCoopers. e-Learning: O Potencial da América Latina. Relatório Técnico, 2001.

RAMOS, Edla. Análise ergonômica do sistema hiperNet buscando o aprendizado da cooperação e da autonomia. 1996. 353 f. Tese (Doutorado) - Departamento de Engenharia de Produção e Sistemas da UFSC. Florianópolis, 1996. Disponível em: $<$ http://www.inf.ufsc.br/ edla/tese/ tese.htm> Acesso em: 23 abr. 2003.

REIGELUTH, Charles M. (org.). Instructional-Design Theories and Models: An Overview of their Current Status. NewJersey: Lawrence Erlbaum Associates Publishers, 1983.

REINHARD, Nicolau; YONEZAWA, Wilson; MORGADO, Eduardo M. The Use of Social Translucence in a Distance Education Support Environment. In: ANNUAL CONFERENCE FOR INFORMATION MANAGEMENT, 15., 2000, Brisbane, Australia. Anais... 2000, p.298-308. Disponível em: <http://www.fia.com.br/professores/reinhard/artigos/212.pdf>. Acesso em: 6 maio 2003.

RHINESMITH, Stephen H. Globalização:o guia do gestor: seis chaves para o sucesso num mundo em mudança. Lisboa: Difusão Cultural, 1993.

ROBERTS, J. M. The story of distance education: a practitioner's perspective, Journal of the American Society for Information Science, v. 47, n. 11, p. 811-816, 1996.

ROMERO, Tania Regina de Souza. A Interação Coordenador e Professor: Um Processo Colaborativo? 1998. Tese (Doutorado) - Lingüística Aplicada ao Ensino de Línguas (LAEL), Pontifícia Universidade Católica de São Paulo, São Paulo, 1998. 
ROMISZOWSKI, Alexander J.; ROMISZOWSKI, Hermelina P. Dicionário de Terminologia de Educação a Distância. Rio de Janeiro: Elaborado para Fundação Roberto Marinho - FRM, 1998. Disponível em: <http://www.abed.org.br/ rbaad/dicionario.pdf $>$ Acesso em: 30 maio 2003.

ROSENBERG, M. J. e-Learning: Estratégias para a Transmissão do Conhecimento na Era Digital. São Paulo: MAKRON Books, 2002. 320 p.

ROVAI, A. Alfred P. A Preliminary Look at the Structural Differences of Higher Education Classroom Communities in Traditional and ALN Courses. Journal of Asynchronous Learning Networks - JALN, v. 6, n. 1, jul. 2002. Disponível em: <http://www.aln.org>. Acesso em: 5 maio 2003.

SANTOS, Andreia Inamorato dos. Web-based Adults' Courses: Searching for the Right Pedagogy. Revista Brasileira de Aprendizagem Aberta a Distância - Associação Brasileira de Educação a Distância (ABED), v. 1, n. 1, ago. 2002. Disponível em: $<$ http://www.abed.org.br>. Acesso em: 6 maio 2003.

SCANDURA, Terri; WILLIAMS, Ethlyn A. Research methodology in management: Current practices, trends, and implications for future research, Academy of Management Journal, Mississippi State, v. 43, n. 6, p. 1248-1264, dez. 2000.

SCHRUM, Lynne; BENSON, Angela. Online Professional Education: a case study of an MBA program through its transition to an online model. Journal of Asynchronous Learning Networks - JALN, v. 4, n. 1, jun. 2000. Disponível em: <http://www.aln.org >. Acesso em: 5 maio 2003.

SEBRAE - Serviço Brasileiro de Apoio às Micro e Pequenas Empresas. Desafio SEBRAE 2003. 2003. Disponível em: <http://www.desafio.sebrae.com.br>. Acesso em: 27 jun. 2003.

SEED - Secretaria de Educação a Distância / Ministério da Educação. Disponível em: $<$ http://www.mec.gov.br/seed/default.shtm>. Acesso em: 20 ago. 2002.

SILVA, Anielson Barbosa da. O Desafio do Administrador do Futuro: Ser um Eterno Aprendiz. In: ENANGRAD, 9. 1998, Itu. Anais... 1998. Disponível em: <www.angrad.com/ artigos_ix_enangrad.asp>. Acesso em: 19 nov. 2002.

SOELTL, Francisco. Do Ensino para o Aprendizado. Revista T\&D, ano XI, ed. 124, p.22-25, abr. 2003. 
SORG, Judith J.; McELHINNEY, James H. A Case Study Describing Student Experiences of Learning in a Context of Synchronous Computer-mediated Communication in a Distance Education Environment. ERIC - Clearinghouse on Information \& Technology, Indiana, 2000. Disponível em: <http://ericit.org/fulltext/ IR020416.pdf>. Acesso em: 12 maio 2003.

SOUKI, Gustavo Q.; ANTONIALLI, Luiz M.; SALGADO, Juliana M. Interdisciplinaridade na era da informação: um estudo sobre a mudança na metodologia de ensino de informática para administradores. In: ENCONTRO ANUAL DA ANPAD, 25., 2001, Campinas, Anais... 2001. 1 CD-Rom.

SOUZA, Maria José Barbosa de; LOPES, Paulo da Costa; GUAGLIARDI, José Augusto. Sistema Informatizado no Ensino de Administração: uma proposta para aquisição de competências em marketing. In: ENANGRAD, 9. 1998, Itu. Anais... 1998. Disponível em: $<$ www.angrad.com/artigos_ix_enangrad.asp>. Acesso em: 19 nov. 2002.

SPECTOR, J. Michael; LA TEJA, Ileana de. Competencias for Oline Teaching. ERIC Clearinghouse on Information \& Technology, Syracuse University, New York, 2001. Disponível em: <http://ericit.org >. Acesso em: 16 maio 2003.

SPICELAND, J. David; HAWKINS, Charlene P. The Impact on Learning of an Asynchronous Active Learning Course Format. Journal of Asynchronous Learning Networks - JALN, v. 6, n. 1, jul. 2002. Disponível em: <http://www.aln.org>. Acesso em: 2 maio 2003.

STAKE, Robert E. Case Studies. In: DENZIN, Norman K.; LINCOLN, Yvonna S. Handbook of Qualitative Research, London: Sage Publications, 1994. p.236-247.

STARR, Linda. An Education World e-Interview With Bernie Dodge: Meet Bernie Dodge -the Frank Lloyd Wright of Learning Environments! Education World, 2000. Disponível em: $<\mathrm{http}$ ://www.educationworld.com/a_tech/tech020.shtml> Acesso em: 24 abr. 2003.

STEPHEN, Leslie. Assessing Your Learning Style. In: BARD, Ray et al. The trainers professional handbook. São Francisco: Jossy Bass, 1987.

TAYLOR, James C. Fifth Generation Distance Education. International Council for Open and Distance Education (ICDE), 2003. Disponível em: $<\mathrm{http}: / / w w w . i c d e . o r g>$. Acesso em: 29 maio 2003.

TESTA, Maurício Gregianin. Fatores Críticos de Sucesso de Programas de Educação a Distância Via Internet. 2002. 127 f. Dissertação (Mestrado) - Escola de Administração, Universidade Federal do Rio Grande do Sul, Porto Alegre, 2002. 
THIOLLENT, Michel. Metodologia da pesquisa-ação. 11. ed. São Paulo: Cortez, 2002. 107 p.

TODOROV, J. C. A importância da educação a distância. Educação a distância, Brasília, v. 3, n. 4 e 5, p. 5-6, abr. 1994.

VASCONCELLOS, Liliana; BERGAMASCHI, Sidnei. Equipes Virtuais. In: SEMEAD Seminários em Administração - Faculdade de Economia, Administração e Contabilidade da Universidade de São Paulo, 5., 2001, São Paulo. Anais... São Paulo: FEA/USP, 2001. 1 CDROM.

VEIGA, Ilma Passos Alencastro (Org.). Técnicas de Ensino: por que não? 13. ed. Campinas: Papirus, 2001. 149 p.

VERDUIN, John R.; CLARK, Thomas A. Distance Education: The Foundations of Effective Practice. San Francisco: Jossey-Bass Publishers, 1991. 279 p.

VIANNEY, João; TORRES, Patrícia; SILVA, Elizabeth. A Universidade Virtual no Brasil: os números do ensino superior a distância no país em 2002. In: SEMINÁRIO INTERNACIONAL SOBRE UNIVERSIDADES VIRTUAIS NA AMÉRICA LATINA E CARIBE. Quito, 2003. Disponível em: <http://www.icoletiva.com.br/informe-uv-brasil.doc $>$. Acesso em: 26 fev. 2003.

VINCENT, Annette; ROSS, Dianne. Personalize training: determine learning styles, personality types and multiple intelligences online. The Learning Organization, Bradford, v. 8, n. 1, p. 36-43, 2001.

WEBCT. Disponível em: <http://www.webct.com >. Acesso em: 26 abr. 2001.

WICK, Calhoun W.; LEÓN, Lu Stanton. The Learning Edge: How Smart Managers and Smart Companies Stay Ahead. New York: McGraw-Hill, 1993. 232p.

WILSON, Henry C. Emergency response preparedness: small group training. Part I - training and learning styles. Disaster Prevention and management, Bradford, v. 9, n. 2, p. 105-116, 2000 .

YIN, Robert K. Estudo de Caso: Planejamento e Métodos. Trad. Daniel Grassi. Porto Alegre: Bookman, 2001. 205 p. 
YONEZAWA, Wilson Massashiro. Uma análise dos conceitos de visibilidade e mobilidade como mecanismo facilitadores em ambientes de ensino a distância na Internet. 2000. 180 f. Tese (Doutorado) - Faculdade de Economia, Administração e Contabilidade, Universidade de São Paulo, São Paulo, 2000.

ZABALA, Antoni. A Prática Educativa: Como ensinar. Trad. Ernani F. da F. Rosa. Porto Alegre: ArtMed, 1998. 


\section{APÊNDICE A: Aulas Virtuais}

\section{INSTRUÇÕES PARA A AULA VIRTUAL 1 (19/08)}

Tema: Gestão de Competência e Estratégia Organizacional

\section{Auto-estudo}

\subsection{Leitura do texto}

Texto: "A gestão de competências e a estratégia corporativa", do livro As Pessoas na Organização (2002).

\subsection{Curso da Abril: “Gestão por Competências"}

Você receberá uma senha por e-mail para acessar este curso. Instruções:

- Acessar a página: $\underline{\text { www.abrileducacao.com.br }}$

- Clicar em 'Meus Cursos'

- Digitar seu No. USP nos campos 'Nome do usuário" e "senha"

- Clicar em 'Gestão de Competências"

- Clicar em 'Gestão de Competências" novamente

- Completar os módulos do Capítulo II (Construindo o Conceito)

- Optativo: Módulo 11 (O link entre estratégia e competência) e Módulo 17 (entrevista com Milton Pereira - Serasa)

- Não precisa fazer os exercícios.

- Sugerimos que você acesse os demais módulos disponíveis.

Importante: Para acessar o curso da Abril da UPD, é necessário levar um fone de ouvido próprio, pois o curso possui áudio. 


\section{Discussão no Fórum}

Questão para discussão no Fórum:

Lembre-se de quando você participou de um processo de seleção.

Quais os atributos que, em sua opinião, mais pesaram na sua escolha para aquela posição?

Esses atributos medem realmente a sua capacidade e o quanto você entrega à organização ou se referem mais ao seu status ou estoque de conhecimento?

Inclua sua resposta no Fórum / categoria: Competências e Estratégia.

Leia as respostas dos colegas e inclua comentários.

Neste momento o Grupo Moderador Temático deve atuar, incentivando a discussão entre os colegas e trazendo materiais a partir de pesquisas sobre o tema.

\section{Chat}

O objetivo do Chat é fazer um fechamento da discussão realizada no Fórum sobre a questão proposta.

\subsection{Regras para funcionamento do Chat}

$\checkmark$ São proibidos comentários não relacionados ao tema em discussão;

$\checkmark \quad$ Incluir frases curtas;

$\checkmark \quad$ Responder especificando o assunto;

Por exemplo: se você quiser concordar com a observação de um colega, utilize: "Eu concordo com o João", porque se você colocar somente "Eu concordo", podem aparecer novas mensagens enquanto você estiver digitando e pode não ficar clara sua posição.

$\checkmark \quad$ Respeitar a figura do moderador/monitor, que é responsável por manter a organização do Chat e incentivar a participação;

$\checkmark \quad$ Respeitar a opinião dos demais participantes do Chat. 


\subsection{Acesso}

Foram reservadas 2 salas na UPD para os alunos que estiverem na FEA.

No caso de dúvidas ou problemas de acesso durante o Chat, entrar em contato.

e-mail: liliana@pobox.com

\subsection{Divisão da turma para o Chat}

A turma foi dividida em três para facilitar a participação de todos no Chat, cada grupo estará utilizando uma sala de Chat. Veja a seguir qual a sua sala e horário.

Obs.: Os alunos podem assistir à discussão em outras salas, que não a sua, mas não podem participar.

Salas e horários do Chat

\begin{tabular}{|l|c|c|}
\hline $\begin{array}{l}\text { 9:30hs. às 10:00hs. - } \\
\text { Sala 1 }\end{array}$ & $\begin{array}{c}\text { 10:00hs. às 10:30hs. - } \\
\text { Sala 2 }\end{array}$ \\
Aluno 1 & & \\
Aluno 2 & & \\
$\ldots$. & & \\
& & \\
& & \\
& & \\
& & \\
& & \\
& & \\
& & \\
& & \\
\end{tabular}




\section{INSTRUÇÕES PARA A AULA VIRTUAL 2 (18/09)}

Tema: Recrutamento e Seleção

\section{Chat}

O objetivo do Chat possibilitar uma discussão aberta, onde todos os alunos possam opinar.

Não é preciso chegar a um consenso e o tema será concluído na próxima aula presencial.

Tema para discussão

Desafios e problemas no processo de seleção: o ponto de vista do candidato e do selecionador.

\subsection{Divisão da turma para o Chat}

A turma foi dividida em 6 grupos para facilitar a participação de todos no Chat, cada grupo estará utilizando uma sala de Chat. Veja a seguir qual a sua sala e horário.

Obs.: É muito importante a observação desta divisão para evitar salas muito cheias, dificultando a discussão.

Salas e horários do Chat

\begin{tabular}{|l|c|c|}
\hline \multicolumn{1}{|c|}{ 9:20hs. às 9:50hs. } & 9:50hs. às 10:20hs. & 10:20hs. às 10:50hs. \\
Aluno 1 $\underline{\text { SALA 1 }}$ & $\underline{\text { SALA 3 }}$ & $\underline{\text { SALA 1 }}$ \\
Aluno 2 & & \\
$\ldots$ & & \\
\hline \multicolumn{1}{|c|}{$\underline{\text { SALA 2 }}$} & $\underline{\text { SALA 4 }}$ & \\
Aluno 1 \\
Aluno 2
\end{tabular}




\subsection{Regras para funcionamento do Chat}

(mesmo texto apresentado na Aula Virtual 1)

\subsection{Acesso}

(mesmo texto apresentado na Aula Virtual 1)

\section{Auto-estudo}

\subsection{Leitura do texto}

Capítulo do livro MÁTTAR Neto, João Augusto. Metodologia científica na era da informática, São Paulo: Saraiva, 2002.

\subsection{Leitura das Instruções para Pesquisa no ProQuest}

Faça download das instruções na página Materiais Adicionais do WebCT.

\section{Atividade}

Realize uma pesquisa no ProQuest sobre um tema relacionado a Recrutamento e Seleção.

Selecione os artigos mais interessantes e salve o conteúdo e referência (revista, autor...) em um arquivo Word.

Inclua uma mensagem no Fórum com o resumo dos artigos encontrados e o texto completo (se disponível) e referência em anexo.

Neste momento o Grupo Moderador Temático deve atuar, incentivando a discussão entre os colegas e trazendo materiais a partir de pesquisas sobre o tema. 


\section{INSTRUÇÕES PARA A AULA VIRTUAL 3 (06/11)}

Tema: Qualidade de Vida no Trabalho

1. WebQuest - Atividade (das 7:30hs. Às 8:20hs.)

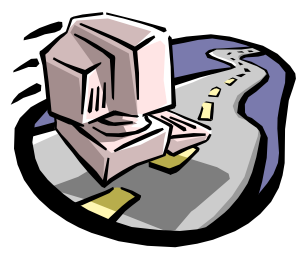

As instruções para realizar esta atividade estão disponíveis no item 3.1. da página Aula Virtual.

Plantão de dúvidas na Sala 1 do Chat.

WebQuest é um modelo para realizar pesquisas direcionadas na Internet, fundamentado na aprendizagem cooperativa e construção do saber. Foi proposto por Bernie Dodge em 1995 e hoje já conta com mais de dez mil páginas na Web de diversas partes do mundo.

2. Chat (8:30hs. Às 9:10hs.)

Tema para discussão

Elaboração de Programa de Qualidade de Vida no Trabalho.

\subsection{Divisão da turma para o Chat}

A turma foi dividida em 2 grupos, considerando a sala da UPD em que o aluno está fisicamente:

- Sala Pró-aluno 1 da UPD: sala 1 do Chat

- Sala Pró-aluno 2 da UPD: sala 2 do Chat

Os alunos que estiverem acessando de outros locais, podem utilizar qualquer uma das salas.

Obs.: É muito importante a observação desta divisão para evitar salas muito cheias, dificultando a discussão.

\subsection{Regras para funcionamento do Chat (mesmo texto apresentado} anteriormente)

\subsection{Acesso (mesmo texto apresentado anteriormente)}

\section{Auto-estudo}

\subsection{Leitura do texto}

"Qualidade de vida no trabalho", Ana Cristina Limongi França e Eliete Bernal Arellano, do livro As Pessoas na Organização (2002). 


\section{APÊNDICE B: Atividade WebQuest}

\section{Qualidade de Vida no Traballho}

WebQuest para alunos de graduação em administração

Profa. Ana Cristina Limongi França (climongi@usp.br)

Profa. Liliana Vasconcellos Jacobsohn (liliana@pobox.com)

\section{Introdução | Tarefa | Processo | Recursos | Avaliação | Conclusão| Referências}

\section{INTRODUÇÃO}

Music Television, um dos canais de TV a cabo mais assistidas no mundo, se tornou autoridade em música para a geração da cultura pop, através de um estilo próprio, documentários inovadores e programação única (www.viacom.com/prodbyunit1.tin?ixBusUnit=19 ; www.mtv.com.br).

Você faz parte de uma equipe multidisciplinar da MTV, com a tarefa de preparar uma proposta de um Programa de Qualidade de Vida para a empresa.

Voltar

\section{TAREFA}

Sua missão é preparar a proposta do Programa de Qualidade de Vida no Trabalho, contendo:

1. Objetivo do Programa

2. Tema

3. Duração

4. Principais ações: incluir as principais ações a serem implementadas, o público alvo de cada uma e, se houve, os especialistas que precisam ser contratados

5. Resultados esperados: O produto desta tarefa deve ser um documento (Word ou Power Point), que será disponibilizado no WebCT para consulta dos colegas. 


\section{PROCESSO}

1. Pesquisar na Internet informações que podem auxiliar no desenvolvimento da proposta (comece utilizando os links sugeridos no tópico Recursos

2. Preparar a proposta de Programa QVT

A seguir, algumas orientações para facilitar seu trabalho:

- Antes de começar, identifique aspectos que poderiam impactar a qualidade de vida dos funcionários de uma empresa como a MTV;

- Busque artigos ou notícias sobre Qualidade de Vida no Trabalho que possam fornecer uma base teórica para propor um Programa;

- Busque exemplos de Programas de Qualidade de Vida em outras empresas e avalie o que pode ser adaptado para a empresa em questão;

- Ao longo da pesquisa salve todas as informações que achar interessante para realização do seu trabalho. Faça anotações e armazene os links (outros endereços na Internet) e bibliografia complementar.

No caso de dúvida, estas poderão ser esclarecidas através do Chat com os professores de plantão.

Voltar

\section{RECURSOS}

Sites de busca:

- www.google.com.br

- www.cade.com.br

- www.altavista.com.br

- http://radaruol.com.br

- www.yahoo.com

Sites de Qualidade de Vida no Trabalho:

- www.abqv.org.br

- www.g-qvt.com.br

- www.ismabrasil.com.br

- www.icoh2003.com.br

Sites de Gestão e Pessoas:

- www.rh.com.br

- $\quad$ www.canalrh.com.br

- www.shrm.org

- www.abrhnacional.org.br

- $\quad$ www.rtd.com.br

Voltar 


\section{AVALIAÇÃO}

A realização deste exercício vale como participação em atividades online.

$\underline{\text { Voltar }}$

\section{CONCLUSÃO}

O objetivo deste exercício é desenvolver habilidades para busca, seleção e organização de informações obtidas na Internet. Além disso, ter contato com os elementos que integram um Programa de Qualidade de Vida no Trabalho e com exemplos de outras empresas.

$\underline{\text { Voltar }}$

\section{REFERÊNCIAS}

http://webquest.sdsu.edu

www.webquest.futuro.usp.br

Última atualização (05/Nov/2002).

Voltar 


\title{
APÊNDICE C: Questionário de Avaliação
}

\author{
Avaliação das Atividades de e-Learning - PARTE 1
}

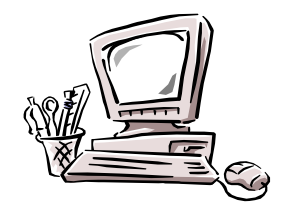

Nome:

O preenchimento deste levantamento é fundamental para o aprimoramento das atividades da disciplina, devendo demorar em torno de 10 minutos. As informações respondidas serão tratadas como confidenciais, sendo divulgado apenas o resultado consolidado de todos os participantes.

Para cada tópico a seguir atribua uma nota de zero (péssimo) a dez (excelente), incluindo um comentário no final para notas inferiores a 6.

1) Avalie o conteúdo disponibilizado: informações, transparências e textos

O conteúdo disponibilizado era importante

O conteúdo disponibilizado era de qualidade

As páginas estavam bem organizadas

Sugestões de outros conteúdos que poderiam ser disponibilizados:

Comentários sobre o conteúdo:

2) Avalie os testes auto-corrigidos Nota (0 a 10)

\begin{tabular}{|l|l|}
\hline Os objetivos estavam claros & \\
\hline As instruções estavam claras & \\
\hline O nível de dificuldade estava adequado & \\
\hline Não tive problemas para realizar os testes auto-corrigidos & \\
\hline Os testes auto-corrigidos contribuíram para o meu aprendizado & \\
\hline
\end{tabular}

Comentários sobre as atividades: 
3) Avalie as demais atividades propostas

Nota (0 a 10)

Os objetivos estavam claros

As instruções estavam claras

O nível de dificuldade estava adequado

Não tive problemas para realizar as atividades

As atividades contribuíram para o meu aprendizado

O feedback recebido foi adequado

Comentários sobre as atividades:

4) Avalie as discussões realizadas no Fórum

Tive a oportunidade de expor minhas opiniões

O nível de participação foi adequado

A postura dos colegas foi adequada

Foi possível discutir os temas com profundidade e de forma crítica

Comentários de colegas foram úteis para meu aprendizado

As discussões contribuíram positivamente para o meu aprendizado

Comentários sobre o Fórum:

5) Avalie as discussões realizadas através de Chat

Nota (0 a 10)

Tive a oportunidade de expor minhas opiniões

A postura dos colegas foi adequada

O número de participantes foi adequado

A duração de 30 minutos foi adequada

O contato e troca entre colegas foi maior do que na aula presencial

Foi possível discutir os temas com profundidade e de forma crítica

Comentários de colegas foram úteis para meu aprendizado

Não senti dificuldade para acompanhar e participar da discussão

As discussões contribuíram positivamente para o meu aprendizado

Comentários sobre o Chat: 
6) Avalie o software WebCT

Foi fácil acessar o site na Internet

O tempo de resposta do sistema (rapidez do sistema) foi adequado

Foi fácil navegar nas telas do sistema

Foi fácil utilizar as ferramentas de comunicação (e-mail, fórum, chat)

Comentários sobre o software:

7) Em média, quantas vezes por semana você acessou o WebCT?

8) A carga de trabalho (dedicação exigida) das atividades de e-learning foi:
( ) Insuficiente
( ) Adequada
( ) Excessiva

9) Você encontrou dificuldades para realizar as atividades de e-learning? ( ) Sim （ ) Não Em caso positivo, assinale abaixo as dificuldades encontradas.

( ) Dificuldade de utilizar o software (WebCT) ( ) Falta de feedback do instrutor/monitor

( ) Falta de tempo

( ) Atividades pouco claras

( ) Não utiliza a Internet com freqüência

( ) Lentidão no acesso

( ) Pouca intimidade com informática/Internet

( ) Recursos tecnológicos insuficientes

( ) Outras: (ex.: capacidade do micro)

10) Foi necessário pedir ajuda?

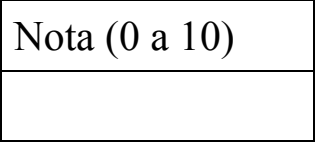

( ) Não

( ) Sim. Neste caso, a ajuda foi:

11) Avaliação geral das atividades de e-learning

As atividades realizadas atenderam minhas expectativas

Desenvolvi habilidades de interação em ambientes virtuais

Melhorei minha competência na utilização do computador

Meu interesse em Gestão de Pessoas aumentou

Eu estava motivado para fazer um bom trabalho 
(Continuação)

O conteúdo da aula virtual (auto-estudo, discussão e Chat) substituiu adequadamente a aula presencial

A carga de trabalho da aula virtual foi adequada para compensar a aula presencial

As atividades realizadas atenderam às minhas expectativas

Eu faria outra disciplina com atividades de e-learning

As atividades de e-learning contribuíram positivamente para o meu aprendizado

Meu aproveitamento geral foi

12) O que poderia ser diferente para aumentar sua participação nas atividades de $e$-learning?

13) O que você mais gostou nesta experiência?

14) O que você menos gostou?

15) Outros comentários e sugestões de melhoria

Obrigado pela participação!

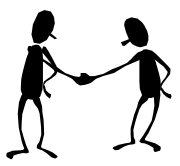




\section{Avaliação das Atividades de e-Learning - PARTE 2}

\begin{tabular}{|l|c|c|c|}
\cline { 2 - 4 } 1) Nível de interesse pelo tema Gestão de Pessoas & Alto & Médio & Baixo \\
\hline Meu interesse por Gestão de Pessoas é: & $($ ) & $($ ) & $($ ) \\
\hline $\begin{array}{l}\text { Considero que a importância da Gestão de Pessoas para a } \\
\text { atuação do administrador seja: }\end{array}$ & $($ ) & $($ ) \\
\hline
\end{tabular}

Para cada item a seguir atribua uma nota de zero (péssimo) a dez (excelente), com objetivo de avaliar as atividades de e-learning.

2) Avalie a atividade WebQuest sobre Qualidade de Vida no Trabalho ( $3^{\mathrm{a}}$ aula virtual)

\begin{tabular}{|l|l|}
\hline Os objetivos estavam claros & \\
\hline As instruções estavam claras & \\
\hline O nível de dificuldade estava adequado & \\
\hline Não tive problemas para realizar as atividades & \\
\hline A atividade contribuiu para o meu aprendizado da matéria & \\
\hline O feedback recebido foi adequado & \\
\hline
\end{tabular}

Comentários sobre as atividades:

4) Qual a contribuição das atividades de e-learning para o desenvolvimento de competências individuais:

\begin{tabular}{|l|l|}
\hline $\begin{array}{l}\text { Auto-aprendizagem (responsabilidade pela condução da própria } \\
\text { aprendizagem) }\end{array}$ & \\
\hline Comunicação em ambientes virtuais & \\
\hline Pesquisa na Internet & \\
\hline Participação em discussões & \\
\hline Formação de comunidades virtuais para troca de conhecimentos & \\
\hline
\end{tabular}

Comentários sobre competências desenvolvidas:

5) Avaliação geral do e-learning:

A integração entre as atividades online e presenciais foi adequada

De forma geral, a contribuição das atividades de e-learning para meu aprendizado foi: 


\section{APÊNDICE D: Questionário de Perfil}

Levantamento do Perfil do aluno

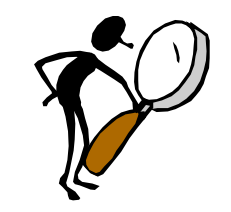

\section{Dados Pessoais}

Nome:

e-mail:

Idade:

Principal ocupação:

Expectativas sobre o curso:

\section{$\underline{\text { Acesso à Internet }}$}

Caracterize seu acesso à Internet, considerando a opção mais usual:

\begin{tabular}{llll}
\hline $\begin{array}{l}\text { Freqüência de } \\
\text { acesso }\end{array}$ & $\square$ Todo dia & $\square$ 3 vezes por semana & $\square \begin{array}{l}1 \text { vez por semana ou } \\
\text { menos }\end{array}$ \\
\hline Período de acesso & $\square$ De dia & $\square$ De noite & \\
\hline Finalidade & \% Lazer & $\%^{\%}$ Faculdade & $\begin{array}{l}\text { Atividade } \\
\text { profissional }\end{array}$ \\
\hline Utilização & $\square$ e-mail & $\square \begin{array}{l}\text { Pesquisa de } \\
\text { informações }\end{array}$ & $\square$ Jogos \\
& $\square$ Chat & $\square$ Lista de discussão & $\begin{array}{l}\text { Donwload de } \\
\text { arquivos }\end{array}$ \\
\hline Local de acesso & $\square$ Em casa & $\square$ No trabalho & $\square$ Na faculdade \\
& $\square$ Outro: & & \\
\hline
\end{tabular}

\section{Infra-estrutura Tecnológica}

\begin{tabular}{llll}
\hline Sistema & $\square$ & Windows & $\square$ Linux \\
& $\square$ & Outro: & \\
\hline $\begin{array}{l}\text { Velocidade da } \\
\text { Internet }\end{array}$ & $\square$ & Linha discada & $\square$ Cabo/ Internet rápida \\
\hline
\end{tabular}




\section{e-Learning}

Qual a sua impressão sobre ensino a distância através da Internet (e-learning)?

Você já participou de algum curso de e-learning?

$\square \operatorname{Sim}$

$\square$ Não

Como você classifica sua

experiência:

Por que?

$\begin{array}{ll}\text { Excelente } & \square \text { Não teve oportunidade } \\ \text { Ótimo } & \square \text { Não se interessa } \\ \text { Regular } & \square \text { Não funciona } \\ \text { Ruim } & \square \text { Outro: }\end{array}$

Você já utilizou o WebCT (software de e-learning) em alguma disciplina da USP?

口 Não

口 Sim, e seu WebCT ID é: 


\section{APÊNDICE E: Roteiro da Entrevista Individual}

- Na sua opinião, quais foram as contribuições do e-learning?

- Considerar: resultado para o aprendizado, desenvolvimento de competências e outros.

- Quais os desafios e dificuldades encontrados na utilização do e-learning?

- Você sentiu pressão devido à sobrecarga de atividades?

- Relacionar com o nível de participação no Fórum

- O que você achou do Chat?

- Contribuição das discussões

- Dificuldade para participar

- Postura dos alunos

- Diferença no nível de participação dos alunos em relação à sala de aula

- Aula presencial sobre a teoria a ser realizada antes ou depois da discussão no Chat

- Como foi a qualidade dos trabalhos resultantes do WebQuest, em relação à atividade semelhante realizada presencialmente?

- Na sua opinião, o e-learning pode contribuir no desenvolvimento da competência de autoaprendizagem do aluno?

- O que você gostaria de fazer diferente na próxima vez que utilizar o e-learning? 